$$
\text { DRA 0412-X }
$$$$
\because A N L / C N S V-T M-192
$$

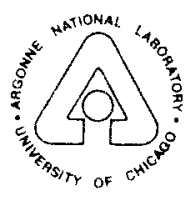

\title{
Organic Rankine-Cycle Power Systems Working Fluids Study: Topical Report No. 2 - Toluene
}

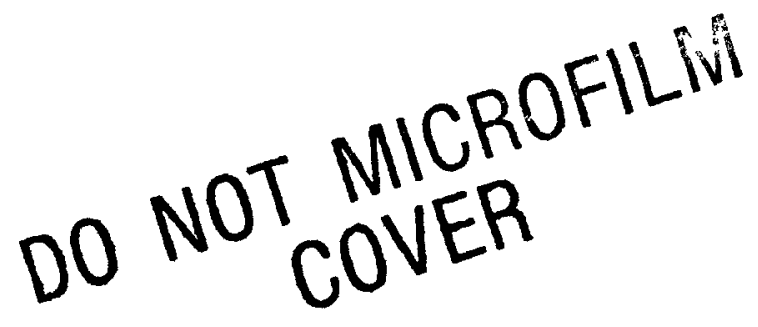

\section{ANL}

\section{ARGONNE NATIONAL LABORATORY}

Energy and Environmental Systems Division 
Argonne National Laboratory, with facilities in the states of Illinois and Idaho, is owned by the United States government, and operated by The University of Chicago under the provisions of a contract with the Department of Energy.

\section{DISCLAIMER}

This report was prepared as an account of work sponsored by an agency of the United States Government. Neither the United States Government nor any agency thereof, nor any of their employees, makes any warranty, express or implied, or assumes any legal liability or responsibility for the accuracy, completeness, or usefulness of any information, apparatus, product, or process disclosed, or represents that its use would not infringe privately owned rights. Reference herein to any specific commercial product, process, or service by trade name, trademark, manufacturer, or otherwise, does not necessarily constitute or imply its endorsement, recommendation, or favoring by the United States Government or any agency thereof. The views and opinions of authors expressed herein do not necessarily state or reflect those of the United States Government or any agency thereof.

\section{DO NOT MICROFILM
COVER}

This informal report presents preliminary results of ongoing work or work that is more limited in scope and depth than that described in formal reports issued by the Energy and Environmental Systems Division.

Printed in the United States of America. Available from National Technical Information Service, U. S. Department of Commerce, 5285 Port Royal Road, Springfield, Virginia 22161. 


\section{DISCLAIMER}

This report was prepared as an account of work sponsored by an agency of the United States Government. Neither the United States Government nor any agency Thereof, nor any of their employees, makes any warranty, express or implied, or assumes any legal liability or responsibility for the accuracy, completeness, or usefulness of any information, apparatus, product, or process disclosed, or represents that its use would not infringe privately owned rights. Reference herein to any specific commercial product, process, or service by trade name, trademark, manufacturer, or otherwise does not necessarily constitute or imply its endorsement, recommendation, or favoring by the United States Government or any agency thereof. The views and opinions of authors expressed herein do not necessarily state or reflect those of the United States Government or any agency thereof. 


\section{DISCLAIMER}

Portions of this document may be illegible in electronic image products. Images are produced from the best available original document. 
ARGONNE NATIONAL LABORATORY

9700 South Cass Avenue, Argonne, Illinois 60439

ANL/CNSV-TM-192

ANL/CNSV-TM--192

DE88 007152

ORGANIC RANKINE-CYCLE POWER SYSTEMS WORKING FLUIDS STUDY:

TOPICAL REPORT NO. 2 -- TOLUENE

by

R.L. Cole, J.C. Demirgian,* and J.W. Allen

Energy and Environmental Systems Division Systems Engineering and Technology Group

Thus document is

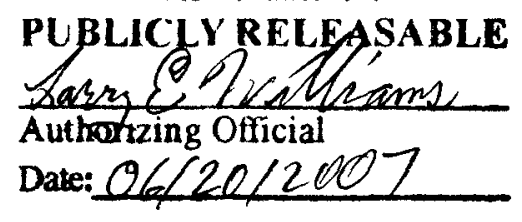

February 1987

work sponsored by

U.S. DEPARTMENT OF ENERGY

Assistant Secretary for Conservation and Renewable Energy

Office of Industrial Programs

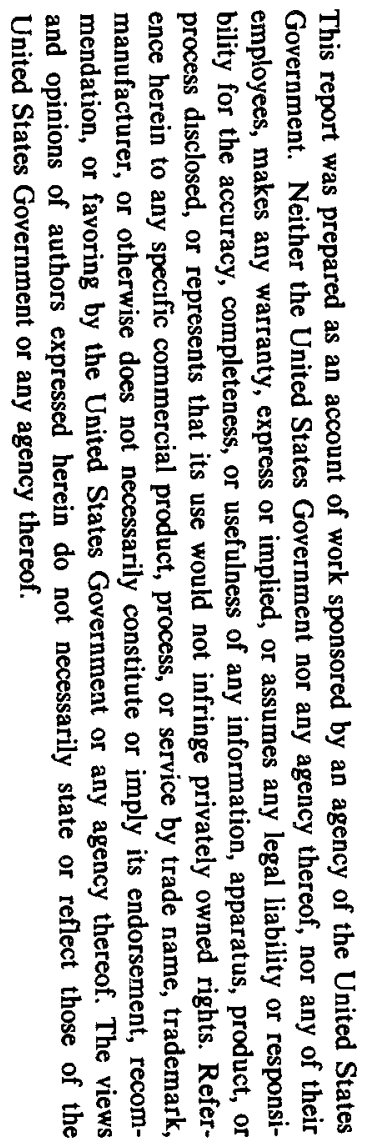

*Analytical Chemistry Laboratory, Argonne National Laboratory. 



\section{CONTENTS}

ACKNOWLEDGMENTS $\ldots \ldots \ldots \ldots \ldots \ldots \ldots \ldots \ldots \ldots \ldots \ldots \ldots \ldots \ldots \ldots \ldots \ldots \ldots$. . . . . . . . . .

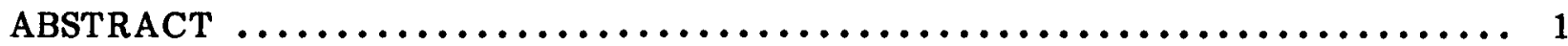

1 INTRODUCTION $\ldots \ldots \ldots \ldots \ldots \ldots \ldots \ldots \ldots \ldots \ldots \ldots \ldots \ldots \ldots \ldots \ldots \ldots \ldots \ldots \ldots$

2 EXPERIMENTAL APPARATUS $\ldots \ldots \ldots \ldots \ldots \ldots \ldots \ldots \ldots \ldots \ldots \ldots \ldots \ldots \ldots \ldots$

2.1 Working Fluid Loop $\ldots \ldots \ldots \ldots \ldots \ldots \ldots \ldots \ldots \ldots \ldots \ldots \ldots \ldots \ldots \ldots \ldots \ldots \ldots$

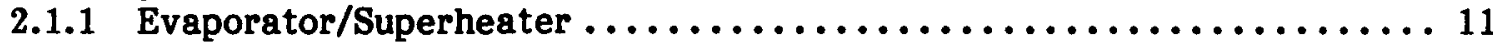

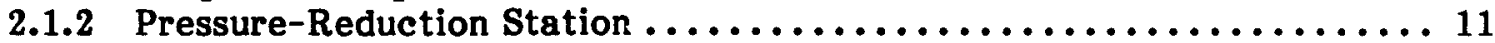

2.1.3 Regenerative Heat Exchanger ........................... 11

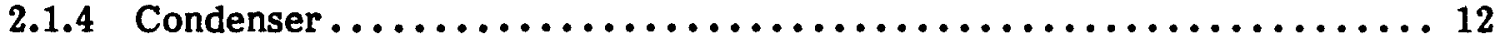

2.1.5 Diaphragm Metering Pump and Pulsation Damper .............. 13

2.1.6 Liquid- and Vapor-Sampling Stations $\ldots \ldots \ldots \ldots \ldots \ldots \ldots \ldots \ldots \ldots \ldots \ldots$

2.1.7 Toluene Degasification Procedure ...................... 16

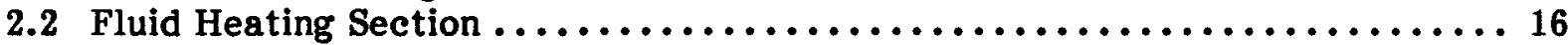

2.3 Heat Rejection System $\ldots \ldots \ldots \ldots \ldots \ldots \ldots \ldots \ldots \ldots \ldots \ldots \ldots \ldots \ldots \ldots \ldots \ldots \ldots$

2.4 Instrumentation, Controls, and Data-Acquisition Systems ............ 17

3 ANALYTICAL TECHNIQUES AND PROCEDURES $\ldots \ldots \ldots \ldots \ldots \ldots \ldots \ldots \ldots \ldots$

3.1 Mass-Spectrometric Gas Analysis ............................ 18

3.2 Gas Chromatography/Mass Spectroscopy ..................... 19

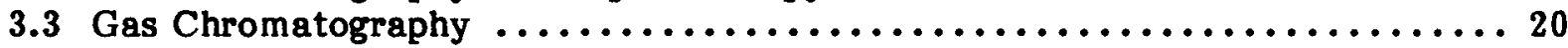

4 SUMMARY OF DYNAMIC LOOP OPERATIONS $\ldots \ldots \ldots \ldots \ldots \ldots \ldots \ldots \ldots \ldots \ldots$

4.1 Test Run No. $1 \ldots \ldots \ldots \ldots \ldots \ldots \ldots \ldots \ldots \ldots \ldots \ldots \ldots \ldots \ldots \ldots \ldots \ldots \ldots \ldots$

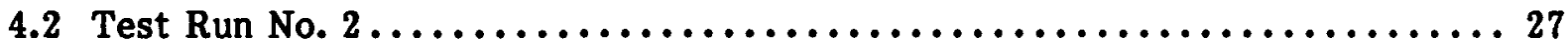

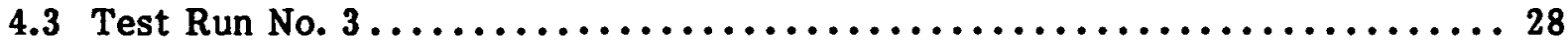

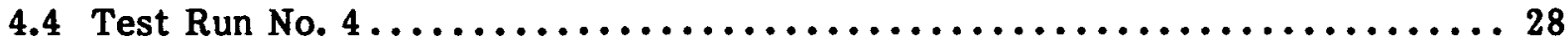

$5 \quad$ RESULTS $\ldots \ldots \ldots \ldots \ldots \ldots \ldots \ldots \ldots \ldots \ldots \ldots \ldots \ldots \ldots \ldots \ldots \ldots \ldots \ldots \ldots \ldots \ldots \ldots$

5.1 Identification of Liquid-Phase Impurities and Degradation Products ....... 34

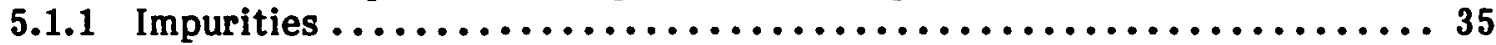

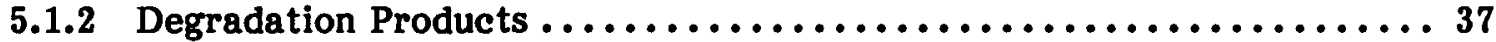

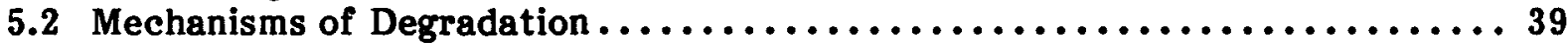

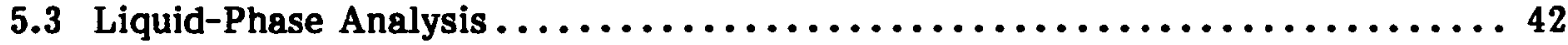

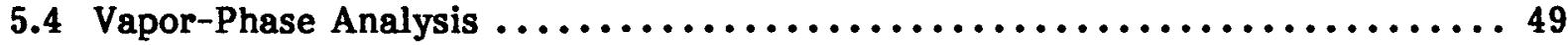

5.4.1 Toluene and Degradation Products $\ldots \ldots \ldots \ldots \ldots \ldots \ldots \ldots \ldots \ldots \ldots \ldots$

5.4.2 Other Vapor-Phase Components ....................... 52

5.5 Relation of the Arrhenius Equation to Degradation .............. 55

5.6 Determination of Coefficients from Experimental Data ............. 56

6 CONCLUSIONS AND RECOMMENDATIONS ..................... 62

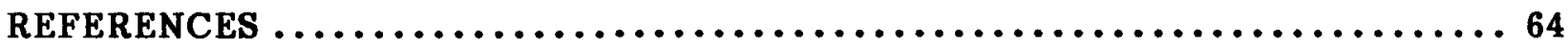




\section{CONTENTS (Cont'd)}

APPENDIX A: Daily Averages, Minima, and Maxima of Evaporator Temperature, Evaporator Pressure, and Condenser Pressure ............ 67

APPENDIX B: Identification of Liquid-Phase Impurities and Degradation

Products ................................... 75

APPENDIX C: Gas Chromatograms of Liquid Samples ................. 111

APPENDIX D: Toluene Degradation Reports $\ldots \ldots \ldots \ldots \ldots \ldots \ldots \ldots \ldots \ldots \ldots \ldots \ldots 14$

APPENDIX E: Computer Program and Predicted Degradation ............. 185

\section{FIGURES}

2.1 Schematic Diagram of Organic Rankine-Cycle Test Loop ............. 6

$2.2 \quad$ Overall View of Test Facility $\ldots \ldots \ldots \ldots \ldots \ldots \ldots \ldots \ldots \ldots \ldots \ldots \ldots \ldots \ldots \ldots \ldots$

$2.3 \quad$ Evaporator Section during Assembly $\ldots \ldots \ldots \ldots \ldots \ldots \ldots \ldots \ldots \ldots \ldots$

2.4 Section Containing Pump, Condenser, Economizer, and Pressure-

Reduction Valves ...................................... 9

2.5 Data-Acquisition and Control Center $\ldots \ldots \ldots \ldots \ldots \ldots \ldots \ldots \ldots \ldots \ldots \ldots \ldots$

2.6 Ideal Test Cycle on a Pressure-Enthalpy Diagram $\ldots \ldots \ldots \ldots \ldots \ldots \ldots \ldots \ldots$

2.7 Schematic Diagram of Evaporator, Showing Thermocouple Locations ........ 14

2.8 Schematic Diagrams of Sampling Stations $\ldots \ldots \ldots \ldots \ldots \ldots \ldots \ldots \ldots \ldots \ldots$

5.1 Mass Spectrum of C8-Cycloalkane Compared with Library Spectra ........ 36

5.2 Mass Spectrum of C2-Biphenyl Compared with Library Spectra . . . . . . . . 38

$5.3 \quad$ Benzaldehyde Concentrations $\ldots \ldots \ldots \ldots \ldots \ldots \ldots \ldots \ldots \ldots \ldots \ldots \ldots \ldots \ldots \ldots$

5.4 Total Degradation with a Least-Squares Fit of Data for Each Test ........ 48

$5.5 \quad$ Bibenzyl Concentrations $\ldots \ldots \ldots \ldots \ldots \ldots \ldots \ldots \ldots \ldots \ldots \ldots \ldots \ldots \ldots \ldots \ldots \ldots$

$5.6 \quad$ C2-Biphenyl Concentrations $\ldots \ldots \ldots \ldots \ldots \ldots \ldots \ldots \ldots \ldots \ldots \ldots \ldots \ldots \ldots \ldots \ldots$

5.7 Ratios of C2-Biphenyl Concentration to Bibenzyl Concentration ......... 50

5.8 Definitions Used in Continuity Equation $\ldots \ldots \ldots \ldots \ldots \ldots \ldots \ldots \ldots \ldots \ldots \ldots$ 


\section{FIGURES (Cont'd)}

5.9 Temperature versus Position for Test No. $1 \ldots \ldots \ldots \ldots \ldots \ldots \ldots \ldots \ldots$. 57

5.10 Temperature versus Position for Test No. $2 \ldots \ldots \ldots \ldots \ldots \ldots \ldots \ldots \ldots, 58$

5.11 Temperature versus Position for Test No. $3 \ldots \ldots \ldots \ldots \ldots \ldots \ldots \ldots \ldots$. 58

5.12 Temperature versus Position for Test No. $4 \ldots \ldots \ldots \ldots \ldots \ldots \ldots \ldots \ldots, \quad 59$

5.13 Temperature versus Position for the Sundstrand/NASA Test $\ldots \ldots \ldots \ldots \ldots \ldots 9$

\section{TABLES}

1.1 Rankine-Cycle Systems Using Toluene $\ldots \ldots \ldots \ldots \ldots \ldots \ldots \ldots \ldots \ldots \ldots$ 4

1.2 Thermal Stability and Materials Compatibility of Toluene .............. 5

2.1 Design Conditions for Toluene Loop........................ 12

Conditions Employed for Gas Chromatography/Flame Ionization
Detection and Gas Chromatography/Mass Spectroscopy Analysis .......... 20

3.2 Components of the Standard $\ldots \ldots \ldots \ldots \ldots \ldots \ldots \ldots \ldots \ldots \ldots \ldots \ldots \ldots, 21$

$4.1 \quad$ Summary of Test Conditions $\ldots \ldots \ldots \ldots \ldots \ldots \ldots \ldots \ldots \ldots \ldots \ldots \ldots, 24$

4.2 Summary of Events for Test No. $1 \ldots \ldots \ldots \ldots \ldots \ldots \ldots \ldots \ldots \ldots \ldots \ldots \ldots, 25$

4.3 Summary of Temperatures and Pressures in Intervals between Samples

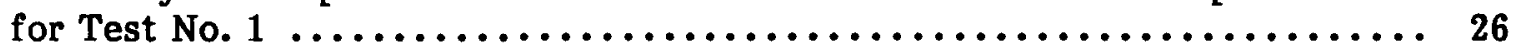

4.4 Summary of Events for Test No. $2 \ldots \ldots \ldots \ldots \ldots \ldots \ldots \ldots \ldots \ldots \ldots \ldots, 27$

4.5 Summary of Temperatures and Pressures in Intervals between Samples for Test No. $2 \ldots \ldots \ldots \ldots \ldots \ldots \ldots \ldots \ldots \ldots \ldots \ldots \ldots \ldots \ldots \ldots \ldots \ldots, 29$

4.6 Summary of Events for Test No. $3 \ldots \ldots \ldots \ldots \ldots \ldots \ldots \ldots \ldots \ldots \ldots, 30$

4.7 Summary of Temperatures and Pressures in Intervals between Samples for Test No. $3 \ldots \ldots \ldots \ldots \ldots \ldots \ldots \ldots \ldots \ldots \ldots \ldots \ldots \ldots \ldots \ldots \ldots, 31$

4.8 Summary of Events for Test No. $4 \ldots \ldots \ldots \ldots \ldots \ldots \ldots \ldots \ldots \ldots \ldots, 32$

4.9 Summary of Temperatures and Pressures in Intervals between Samples for Test No. 4 . $\ldots \ldots \ldots \ldots \ldots \ldots \ldots \ldots \ldots \ldots \ldots \ldots \ldots \ldots \ldots \ldots \ldots, 33$

5.1 Degradation of Selected Components at $635^{\circ} \mathrm{F} \ldots \ldots \ldots \ldots \ldots \ldots \ldots \ldots, 43$

5.2 Degradation of Selected Components at $600^{\circ} \mathrm{F} \ldots \ldots \ldots \ldots \ldots \ldots \ldots \ldots .44$ 


\section{TABLES (Cont'd)}

5.3 Degradation of Selected Components at $650^{\circ} \mathrm{F} \ldots \ldots \ldots \ldots \ldots \ldots \ldots \ldots$

5.4 Degradation of Selected Components at $677^{\circ} \mathrm{F} \ldots \ldots \ldots \ldots \ldots \ldots$

5.5 Toluene Degradation in the Vapor Phase $\ldots \ldots \ldots \ldots \ldots \ldots \ldots \ldots \ldots \ldots \ldots$

5.6 Relative Concentration of Background and Oxygen-Containing

Components in Vapor Phase ............................ 53

5.7 Comparison of Predicted and Measured Degradation for Single-Reaction Model ............................................ 60

5.8 Comparison of Predicted and Measured Degradation for Two-Reaction

Model .......................................... 61 


\section{ACKNOWLEDGMENTS}

We thank John Eustis of the U.S. Department of Energy, Waste Energy Recovery and Advanced Cogeneration, Office of Industrial Programs, Conservation and Renewable Energy Program for support and guidance that made this project possible. In addition, we thank Frank Herbaty, Senior Program Manager, and Norman Swift and John Purcell, Program Managers, of the U.S. Department of Energy Chicago Operations Office for their guidance.

Argonne National Laboratory management who assisted with this project include Harvey Drucker, Associate Laboratory Director; William Schertz, Director of the Systems Engineering and Technology Group in the Energy and Environmental Systems (EES) Division; and James Lazar, Manager of the EES Resource Recovery Systems Section.

Technicians who assisted with the project are Roy Seglem, Alvin Wantroba, and Clarence Clark. Our secretaries are Betty O'Meara and Denise Voss. We thank Anthony Thomas, Herbert Stevens, Lyle Genens, Chandrakant Panchal, and William Kolb for their assistance in designing and constructing the organic Rankine-cycle loop. Toni Engelkemeier, Kim Quandt, and Sara Timmers assisted with the chemical analysis.

We thank Floyd Bennett and Kathryn Macal of the editorial staff; Linda Samek-Haley and Mary Jo Koelbl of the computer graphics group; the staff of the Word Processing Center; and the staff of the Graphic Arts Department for their assistance in production of this report.

Finally, we thank Dana Ragaller and Lowell Sibert of Sundstrand Aviation Operations for providing data on the Sundstrand/National Aeronautics and Space Administration Rankine-cycle loop tests and for stimulating discussions of toluene degradation. 


\title{
ORGANIC RANKINE-CYCLE POWER SYSTEMS WORKING FLUIDS STUDY:
}

TOPICAL REPORT NO. 2 - TOLUENE

by

\author{
R.L. Cole, J.C. Demirgian, and J.W. Allen
}

\begin{abstract}
The U.S. Department of Energy initiated an investigation at Argonne National Laboratory in $\mathbf{1 9 8 2}$ to experimentally determine the thermal stability limits and degradation rates of toluene as a function of maximum cycle temperature. Following the design and construction of a dynamic test loop capable of closely simulating the thermodynamic conditions of typical organic Rankine-cycle (ORC) power systems, four test runs, totaling about $3900 \mathrm{~h}$ of test time and covering a temperature range of $600-677^{\circ} \mathrm{F}$, were completed. Both liquid and noncondensable-vapor (gaseous) samples were drawn periodically and analyzed using capillary-column gas chromatography, gas chromatography/mass spectrometry, and mass spectrometry. A computer program that can predict degradation in an ORC engine was developed. Experimental results indicate that, if oxygen can be excluded from the system, toluene is a stable fluid up to the maximum test temperature; the charge of toluene could be used for several years before replacement became necessary. (Additional data provided by Sundstrand Corp. from tests sponsored by the National Aeronautics and Space Administration indicate that toluene may be used at temperatures up to $750^{\circ} \mathrm{F}$.) Degradation products are benign; the main liquid degradation products are bibenzyls, and the main gaseous degradation products are hydrogen and methane. A cold trap to remove gaseous degradation products from the condenser is necessary for extended operation.
\end{abstract}

\section{INTRODUCTION}

Recovery of waste heat in an economically acceptable manner from various industrial processes has been a vital facet of U.S. energy policy over the past several years. The Rankine-cycle power system (RCPS), using organic working fluids, has long been recognized as one of the viable technologies. (These systems operate on the Rankine cycle, in which a working fluid is alternately vaporized and condensed using waste heat and a low-temperature heat sink. The high-temperature, high-pressure fluid is expanded through an expansion engine to produce mechanical power or electricity.) 
Typically, an organic Rankine-cycle power system (ORCPS) can use single-stage turbines and still achieve higher cycle efficiencies than systems using low-temperature steam, because of the relatively low enthalpy drop and full admission through the nozzle made possible by the high molecular weight of the organic fluid.

However, serious concerns over the long-term thermal stability of organic fluids and effects on system performance, reliability, and overall economic viability have impeded widespread development and deployment of this technology to date. Prototypical systems designed on the basis of thermal-stability results from static capsule testing have failed to operate entirely to the satisfaction of their developers. The working fluid must also be compatible with the common materials of construction at system design temperatures. Reliable data are required to establish the maximum possible temperature and the fluid replacement rate. Dynamic loop testing of working fluids of interest could provide such data for system designers. The findings presented here are part of a concerted effort under way to alleviate performance, reliability, and economic concerns and accelerate development and deployment of this technology in the industrial sector of the U.S. economy.

The thermal stability of an organic fluid is a general term used to describe the ability of the fluid to withstand a given temperature without significant decomposition. Above a certain temperature, an organic fluid will begin to decompose at a measurable rate, and this rate will increase with increasing temperature. In an "inert" environment, a fluid can decompose as a result of breakage of chemical bonds, without reacting with other materials. Stability against this type of decomposition is a measure of the inherent bond strength of the molecule and has been referred to as thermal stability. ${ }^{1}$ The term thermochemical stability is used to describe the stability of a fluid in contact with the materials in the working environment. Thus, the thermochemical-stability temperature of the fluid provides a limitation on the maximum allowable operating temperature of a prototypical ORCPS. The thermochemical-stability temperature is typically less than the thermal-stability temperature by approximately $100-400^{\circ} \mathrm{F} .1$ In this report, the single term thermal stability will be used to indicate stability of a fluid in its working environment.

In a previous study, based on systems analysis covering performance and economic considerations (rate of return on investment, ROI), six organic fluids were identified to harness the energy content of a range of industrial waste-heat streams. ${ }^{2}$ However, questions about long-term thermal-stability temperatures of these fluids for this application could not be explicitly answered on the basis of available information. In some cases, reliable data were either nonexistent or inconclusive. This uncertainty became the motivation for undertaking the current dynamic loop testing program.

The six fluids to be investigated under this program are as follows:

- Fluorinol 85 (a mixture of 85 mole percent [mol \%] trifluoroethanol, $\mathrm{CF}_{3} \mathrm{CH}_{2} \mathrm{OH}$, and $15 \mathrm{~mol} \%$ water),

- 2-methylpyridine/water (a mixture of $35 \mathrm{~mol} \%$ 2-methylpyridine, $\mathrm{C}_{6} \mathrm{H}_{7} \mathrm{~N}$, and $65 \mathrm{~mol} \%$ water), 
- R-113 (1,1,2-trichloro-1,2,2-trifluoroethane, $\left.\mathrm{CCl}_{2} \mathrm{~F}-\mathrm{CClF}_{2}\right)$,

- Toluene (methylbenzene, $\mathrm{C}_{6} \mathrm{H}_{5}-\mathrm{CH}_{3}$ ),

- Methanol $\left(\mathrm{CH}_{3} \mathrm{OH}\right)$, and

- R-11 (trichlorofluoromethane, $\mathrm{CCl}_{3} \mathrm{~F}$ ).

Detailed thermodynamic properties and other characteristics of these fluids are listed in Ref. 2. In this report, discussion is limited to toluene.

Two approaches are used to obtain reliable data on thermal stability: static capsule tests and dynamic loop tests. Capsule tests of fluids serve as an important screening tool in qualitatively and, to some extent, quantitatively establishing the effects of pertinent variables on the fluid degradation rates. However, the results cannot be easily and reliably related to a prototypical system, because not all system operating conditions can be duplicated in the capsule tests. In comparison with a complete system test, small dynamic loop testing is a simpler, more cost-effective approach that still provides a fairly good simulation of the system operating conditions. This approach also allows testing over a wide range of operating temperatures and pressures, including those that could lead to some detrimental effects on an ORCPS due to fluid degradation. (It would be unwise to put an expensive, full-sized system at risk by using it to conduct thermal-stability experiments.)

A review of previous studies was undertaken to develop a viable testing approach for toluene. Table 1.1 lists the RCPS designs for which this fluid was chosen. ${ }^{3-11}$ From these data, it can be seen that the temperature range for toluene is $240-450^{\circ} \mathrm{C}$ $\left(465-842^{\circ} \mathrm{F}\right)$. Previous work associated with thermal-stability investigations is summarized in Table $1.2 .1,5,7,8,12,13$ Only two static capsule tests of toluene, and no dynamic loop tests, were found in the literature. Although the test reported by Miller et al. ${ }^{13}$ is too short in duration to be of much use, the capsule tests by Sundstrand ${ }^{5}$ are extensive.

On the basis of data from the cited work, we decided to examine toluene over a temperature range of 450 to approximately $700^{\circ} \mathrm{F}$, the maximum design temperature of our dynamic loop, using a test-run time of about $1000 \mathrm{~h}$ at each temperature selected. 
TABLE 1.1 Rankine-Cycle Systems Using Toluene

\begin{tabular}{|c|c|c|c|c|}
\hline Organization & Application & $\begin{array}{l}\text { Rated } \\
\text { Power } \\
(\mathrm{kW})\end{array}$ & $\begin{array}{l}\text { Maximum Fluid } \\
\text { Temperature } \\
\left({ }^{\circ} \mathrm{F}\right)\end{array}$ & Reference \\
\hline Sundstrand & Total energy plant & 100 & 825 & $3-5$ \\
\hline Sundstrand & Remote power & 1 & 725 & $5-8$ \\
\hline Sundstrand & 25-passenger bus & 67 & 700 & 5,9 \\
\hline Sundstrand & Bottoming cycle & 600 & 465 & $5,7,8,10$ \\
\hline $\begin{array}{l}\text { Messerschmidt } \\
\text { Bolkow-Blohm }\end{array}$ & Solar power & 150 & 842 & 7,8 \\
\hline Sundstrand & Solar power & 32 & 572 & $5,7,8$ \\
\hline Sundstrand & & 1.5 & - & 5 \\
\hline Sundstrand & Solar irrigation & 200 & - & 5 \\
\hline $\begin{array}{l}\text { Ford Aerospace } \\
\text { and Communica- } \\
\text { tions }\end{array}$ & Solar power & 25 & 750 & 11 \\
\hline
\end{tabular}


TABLE 1.2 Thermal Stability and Materials Compatibility of Toluene

\begin{tabular}{|c|c|c|c|c|c|}
\hline $\begin{array}{l}\text { Type } \\
\text { of Test }\end{array}$ & $\begin{array}{l}\text { Test } \\
\text { Duration } \\
\text { (h) }\end{array}$ & \begin{tabular}{c}
\multicolumn{2}{c}{ Maximum } \\
Test Temp. \\
$\mathrm{T}_{\max }\left({ }^{\circ} \mathrm{F}\right)$
\end{tabular} & $\begin{array}{l}\text { Materials } \\
\text { in Contact } \\
\text { with Fluid } \\
\text { at } T_{\max }\end{array}$ & Comments & Reference \\
\hline Capsule & $>336$ & 720 & 1008 steel & - & 1 \\
\hline \multirow[t]{2}{*}{ Theoretical } & - & $700-730$ & - & $\begin{array}{l}\text { Based on } \\
\text { strength of } \\
\text { molecular } \\
\text { bonds }\end{array}$ & 1 \\
\hline & $\begin{array}{l}- \\
-\end{array}$ & $\begin{array}{l}750 \\
896\end{array}$ & $\begin{array}{l}- \\
-\end{array}$ & $\begin{array}{l}\text { No support- } \\
\text { ing data } \\
\text { No support- } \\
\text { ing data }\end{array}$ & $\begin{array}{c}12,13 \\
7,8\end{array}$ \\
\hline Capsule & $\begin{array}{l}1000 \\
1000 \\
1000 \\
1000\end{array}$ & $\begin{array}{l}605 \\
700 \\
800 \\
900\end{array}$ & $\begin{array}{l}\text { ss } \\
\text { ss } \\
\text { ss } \\
\text { ss }\end{array}$ & $\begin{array}{l}4.2 \times 10^{-5}(\text { see } \\
\text { note b) } \\
6.85 \times 10^{-4} \\
2.1 \times 10^{-2} \\
9.9 \times 10^{-1}\end{array}$ & 5 \\
\hline
\end{tabular}

${ }^{a_{S S}}=$ stainless steel.

$b_{\text {Degradation }}$ rate in $\% / \mathrm{h}$. 


\section{EXPERIMENTAL APPARATUS}

Dynamic test loops have previously been designed and constructed to study the thermal stability of organic working fluids for RCPS applications. Heat-addition methods have included direct electrical heating and indirect electrical heating by means of a salt bath or condensing heat-transfer fluid. Most of the loops built by others have used water-cooled condensers but have not included economizers. The types of pumps used have included diaphragm pumps, regenerative turbine pumps, and piston pumps. Fluid flow rates have varied from 10 to more than $250 \mathrm{lb} / \mathrm{h}$. The fluid inventory circulation time has varied from 1.8 to $7.8 \mathrm{~min}$ for these systems. For comparison, the prototypical organic Rankine-cycle (ORC) engine systems that have been built and operated have a circulation time range of 2.1-12.6 min.

In our experiment, the basic loop consists of a vaporizer/superheater, a pressure reduction station, an economizer/preheater (regenerative heat exchanger), a condenser, and a diaphragm-type metering pump. Indirect heating using condensing Dowtherm ${ }^{\text {(i) } A}$ was selected for our system because of its low vapor pressure at relatively high temperature $\left(14.7\right.$ psia at $\left.495^{\circ} \mathrm{F}\right)$. Figure 2.1 shows a flow schematic of the dynamic test loop used in this investigation. Figure 2.2 shows an overall view of the test facility. Figure 2.3 shows the uninsulated evaporator/superheater section, and Fig. 2.4 shows the section containing pressure reduction valves, economizer, condenser, metering pump, pulsation damper, and liquid and noncondensable-vapor sampling stations. Figure 2.5 shows the system controls and data-acquisition center. Details of these components are given following a discussion of general design considerations.

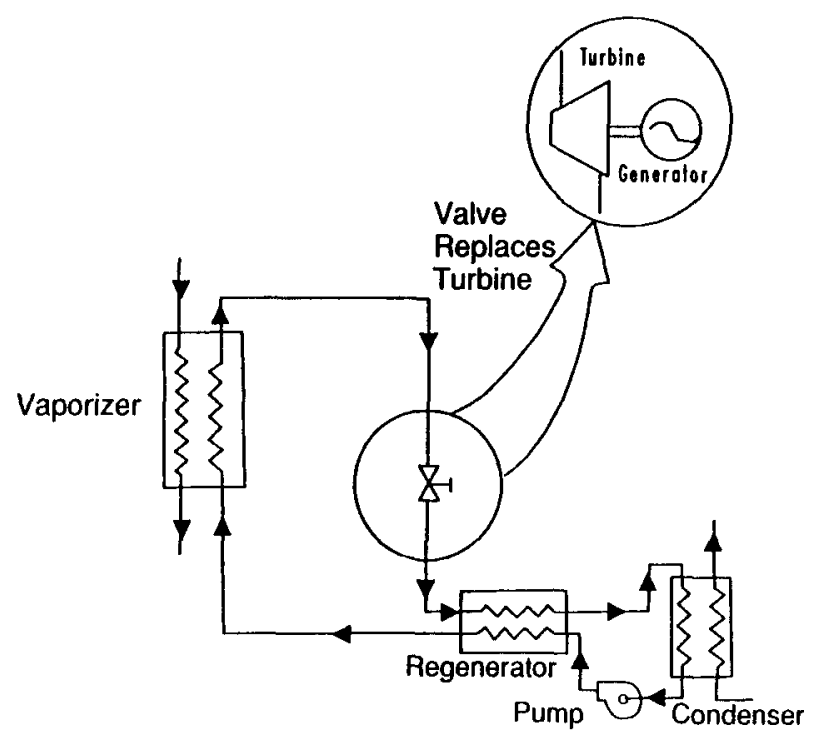

FIGURE 2.1 Schematic Diagram of Organic Rankine-Cycle Test Loop

*"Dowtherm ${ }^{\text {Bn }}$ is a trademark of Dow Chemical USA, Midland, Mich. 


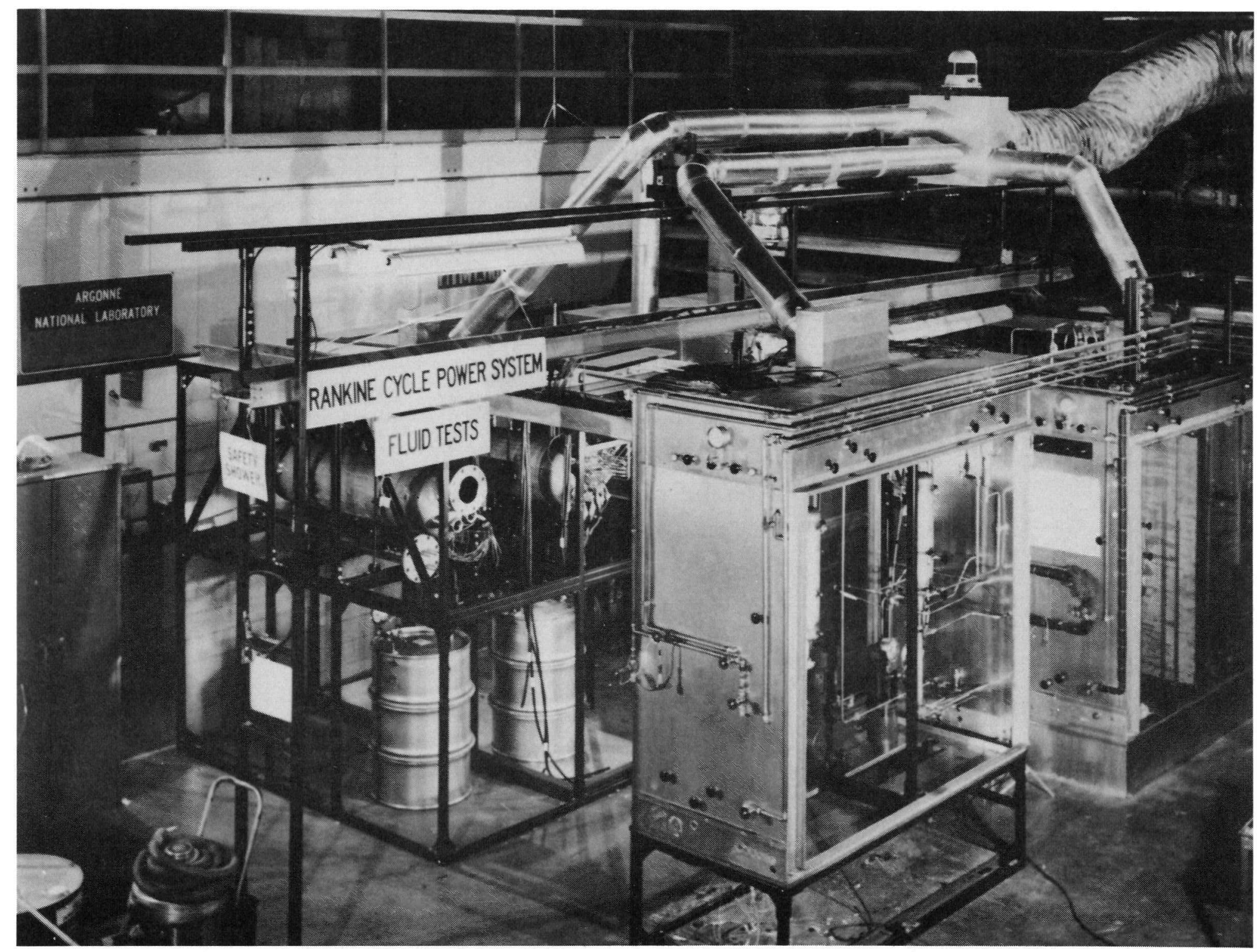

FIGURE 2.2 Overall View of Test Facility 


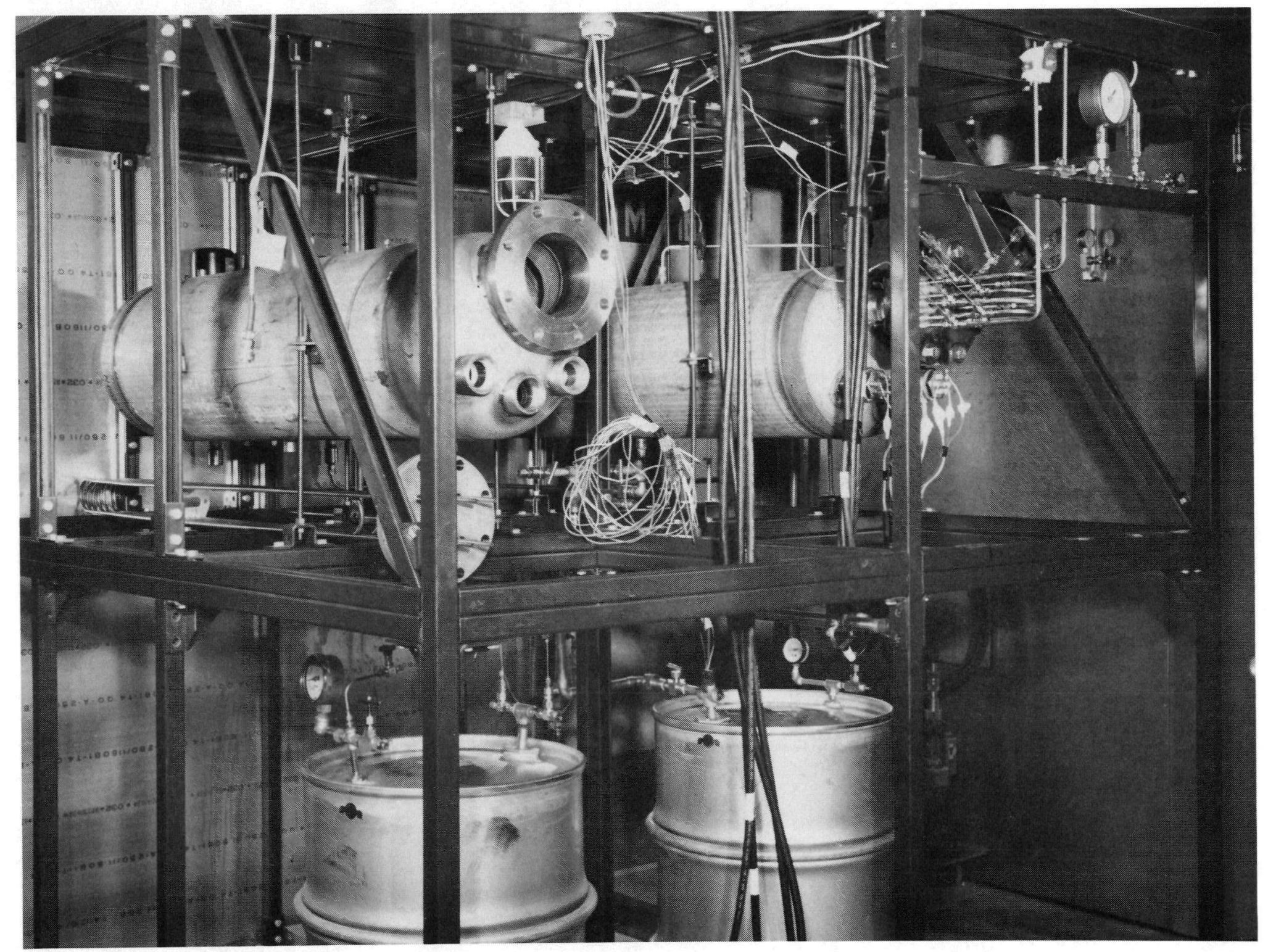




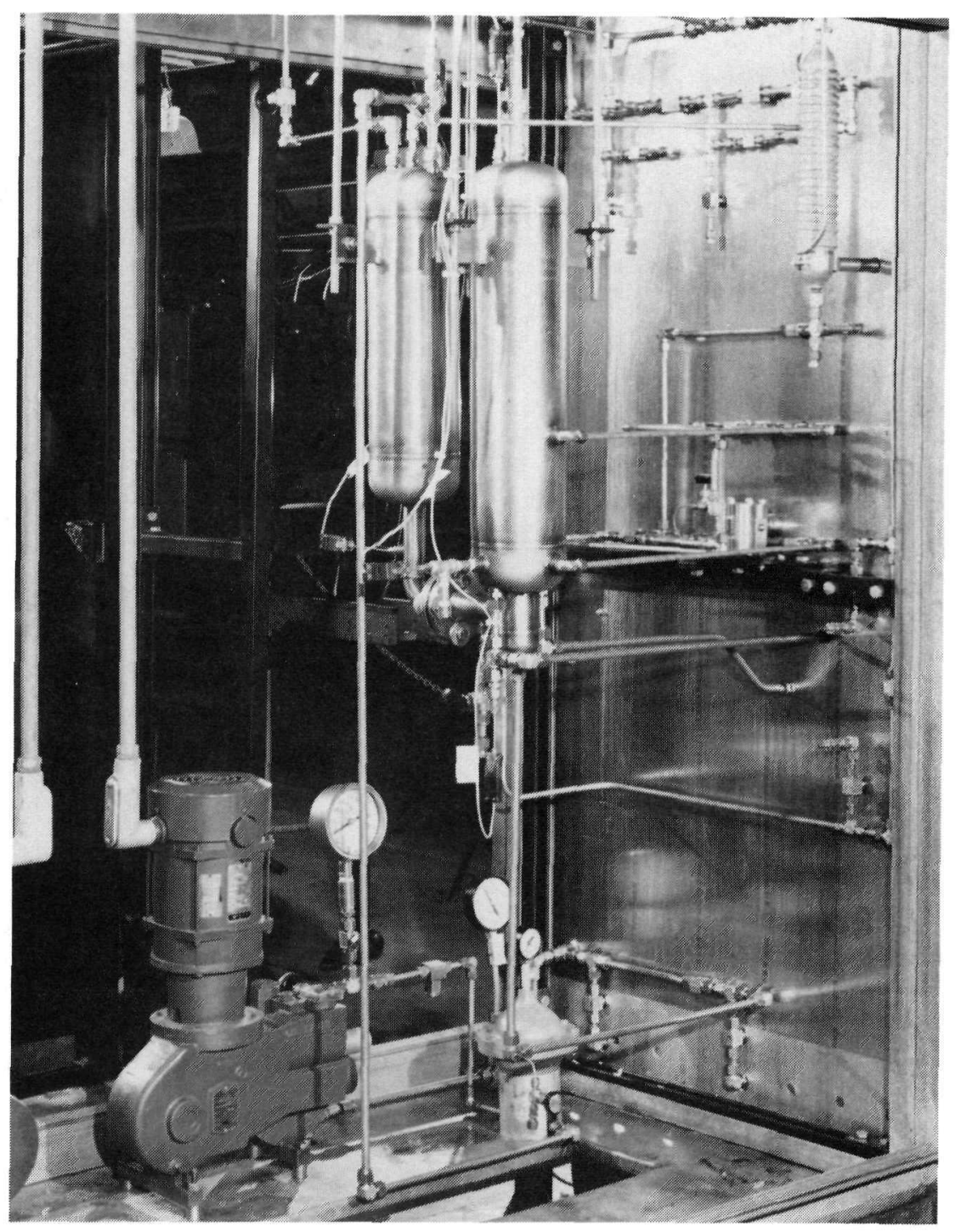

FIGURE 2.4 Section Containing Pump, Condenser, Economizer, and Pressure-Reduction Valves

The dynamic test loops are designed to conduct long-term (approximately $1000 \mathrm{~h}$ per test) thermal-stability tests under simulated prototypical thermodynamic operational conditions. Stainless steel (SS, types 304 and 316 ) is used to minimize potential degradation resulting from interaction with loop materials. The system is designed to be leak-tight in order to prevent potential contamination of the fluids by in-leakage of air. Sampling stations are provided to periodically withdraw liquid and noncondensable-vapor samples for chemical analysis. Adequate instrumentation and controls are provided for monitoring the loops during steady-state operations, as well as to diagnose off-design operations. Safety controls are provided for automatic shutdown of the system in case of major system malfunctions. 


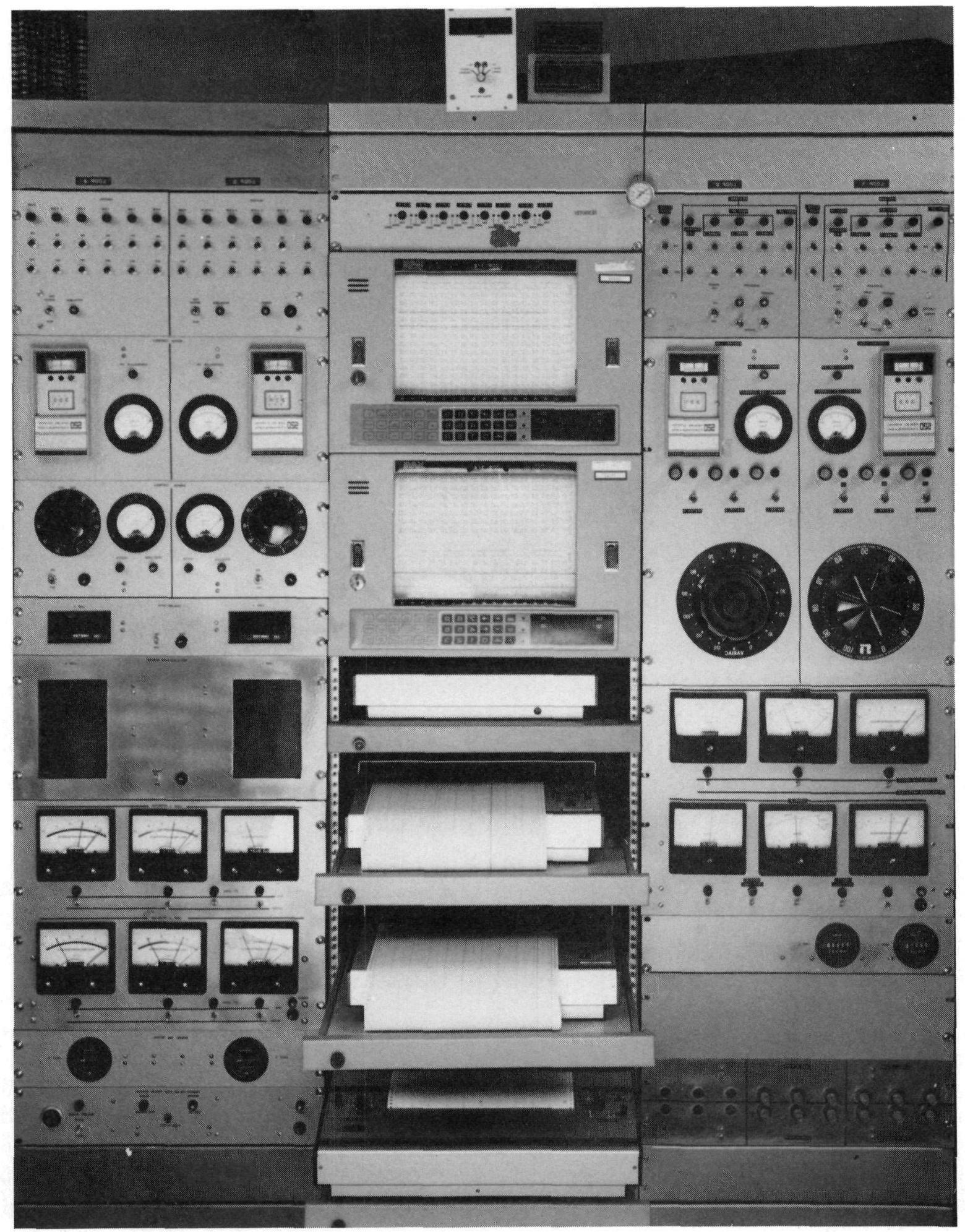

FIGURE 2.5 Data-Acquisition and Control Center 
The design conditions for the dynamic loop are listed in Table 2.1. The ideal design point test cycle is presented on the pressure-enthalpy $(P-h)$ diagram of Fig. 2.6.

The system layout shown in Fig. 2.1 has four major subsystems: the working fluid loop; the fluid heating section; the heat rejection section; and the instrumentation, controls, and data-acquisition system.

\subsection{WORKING FLUID LOOP}

The working fluid loop consists of an evaporator/superheater, a set of pressurereduction valves, a regenerative heat exchanger, a condenser, a metering pump, and a pulsation damper. A special procedure is used to remove dissolved air from the toluene before filling the loop.

\subsubsection{Evaporator/Superheater}

The evaporator/superheater is constructed of 0.375-in.-O.D., 0.035-in.-wall type 304 SS tubing. A tube approximately $79 \mathrm{ft}$ long is formed in a coil of seven loops, each approximately $12 \mathrm{ft}$ long, to provide a total internal heat-transfer surface area of 6.30 $\mathrm{ft}^{2}$. This results in an average heat flux of $4310 \mathrm{Btu} / \mathrm{h} \cdot \mathrm{ft}^{2}$ for toluene, operating at evaporator-outlet conditions of $700^{\circ} \mathrm{F}$ and 500 psia. Approximately $8 \mathrm{~kW}$ of power is required to heat the toluene.

As shown in Fig. 2.7, the evaporator/superheater is instrumented with 9 type-E thermocouples. Figure 2.7 also shows the locations of thermocouples near the pressurereduction valve (equivalent to the turbine inlet) and in the regenerative heat exchanger.

\subsubsection{Pressure-Reduction Station}

The pressure-reduction section serves the function of an expansion turbine, though without producing any power. Two Nupro SS-6BW-STE bellows-sealed stainlesssteel valves serve to reduce the pressure of superheated vapor emerging from the evaporator/superheater to the condenser pressure. These valves are manually operated and require only minor adjustments during operation.

\subsubsection{Regenerative Heat Exchanger}

The purpose of the regenerative heat exchanger (economizer) is to recover a substantial amount of heat from high-temperature, low-pressure vapor after the pressure-reduction station, rather than rejecting this heat through the condenser. In a prototypical system, this would result in increased system efficiency; in the dynamic loop, it reduces consumption of electricity. 
TABLE 2.1 Design Conditions for Toluene Loop

\begin{tabular}{|c|c|c|c|}
\hline Component and Location & $\underset{\left({ }^{\circ} \mathrm{F}\right)}{\operatorname{Temp})^{\mathrm{T}}}$ & $\begin{array}{l}\text { Pressure, } P \\
\text { (psia) }\end{array}$ & $\begin{array}{c}\text { Fluid Flow } \\
\text { Rate } \\
\left(1 b_{m} / h\right)^{a}\end{array}$ \\
\hline \multicolumn{4}{|l|}{ Evaporator } \\
\hline $\begin{array}{l}\text { Dowtherm A vapor } \\
\text { Working fluid, outlet }\end{array}$ & $\begin{array}{l}720 \\
700\end{array}$ & $\begin{array}{r}<150 \\
500\end{array}$ & $\overline{125}$ \\
\hline $\begin{array}{l}\text { Pressure-reduction } \\
\text { station outlet }\end{array}$ & 698 & 18 & 125 \\
\hline \multicolumn{4}{|l|}{$\begin{array}{l}\text { Regenerative heat } \\
\text { exchanger }\end{array}$} \\
\hline $\begin{array}{l}\text { Vapor, outlet } \\
\text { Liquid, outlet }\end{array}$ & $\begin{array}{l}470 \\
329\end{array}$ & $\begin{array}{r}18 \\
516\end{array}$ & $\begin{array}{l}125 \\
125\end{array}$ \\
\hline \multicolumn{4}{|l|}{ Condenser ${ }^{a}$} \\
\hline $\begin{array}{l}\text { Vapor } \\
\text { Liquid } \\
\text { Water, inlet } \\
\text { Water, outlet }\end{array}$ & $\begin{array}{r}470 \\
120 \\
80 \\
212^{b}\end{array}$ & $\begin{array}{l}18 \\
18 \\
<5 \\
<5\end{array}$ & $\begin{array}{l}125 \\
125 \\
{[0.6]} \\
{[0.6]}\end{array}$ \\
\hline \multicolumn{4}{|l|}{ Pump } \\
\hline $\begin{array}{l}\text { Inlet } \\
\text { Outlet }\end{array}$ & $\begin{array}{l}120 \\
130\end{array}$ & $\begin{array}{r}18 \\
525\end{array}$ & $\begin{array}{l}125 \\
125\end{array}$ \\
\hline
\end{tabular}

The regenerative heat-exchanger shell is constructed of a 5-in.-O.D., 20-in.-long, schedule 40, type 304 SS pipe. The shell is fitted with a double coil made of a 42 -ft-long, 0.5-in.-O.D., 0.035-in.-wall, type 304 SS tube. A tubular spacer baffle centers the coil in an annulus and provides cross-flow conditions across the tube bundle as the vapor moves downward toward the outlet. The coil inlet and outlet pass through the bottom end of the shell via vertical welded nozzles. The high-pressure, low-temperature liquid from the pump is heated by the low-pressure superheated vapor before it flows to the evaporator/superheater section.

\subsubsection{Condenser}

The condenser is a shell-and-tube heat exchanger similar in construction to the regenerative heat exchanger; the organic fluid condenses on the shell side, and laboratory 


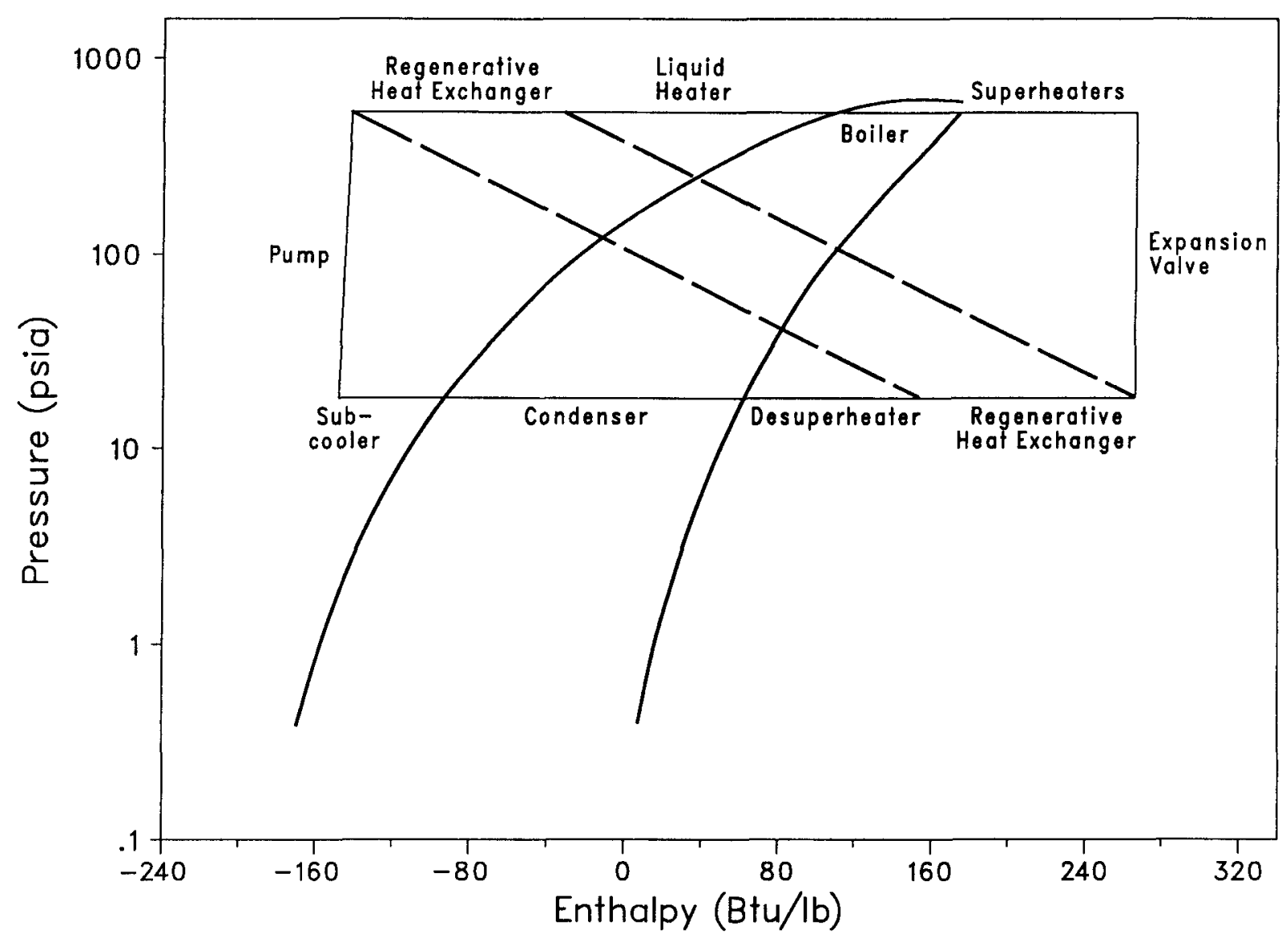

FIGURE 2.6 Ideal Test Cyele on a Pressure-Enthalpy Diagram

cooling water flows through the tube section. The vapor from the regenerative heat exchanger enters at the bottom of the condenser and flows upward in the shell, where it is condensed by contact with the cold tube. Noncondensable gaseous components tend to accumulate in the condenser, from which they are periodically removed for chemical analysis. The construction material is type 304 stainless steel. The shell is a 25 -in.-long, 5-in.-O.D., schedule 40 pipe with spherical caps welded at both ends. The coil is fabricated from a 50-ft-long, 0.5-in.-O.D., 0.035-in.-wall tube. The coil is centered in the annulus by a baffle, which directs the vapor in a cross-flow pattern to the lower drain.

\subsubsection{Diaphragm Metering Pump and Pulsation Damper}

A Milton Roy FR 151-144 diaphragm metering pump with a rating of $27.9 \mathrm{gal} / \mathrm{h}$ and 600 psia at approximately 9-psia net positive suction head (NPSH) is used for pressurizing and circulating the fluids. This pump is constructed of stainless steel and uses a Teflon diaphragm. Teflon is inert at the design fluid temperature levels of the pump. The pump flow rate is easily adjusted over a range of $0.1-0.4 \mathrm{gal} / \mathrm{min}$ by changing the stroke length (using a micrometer adjustment screw). 


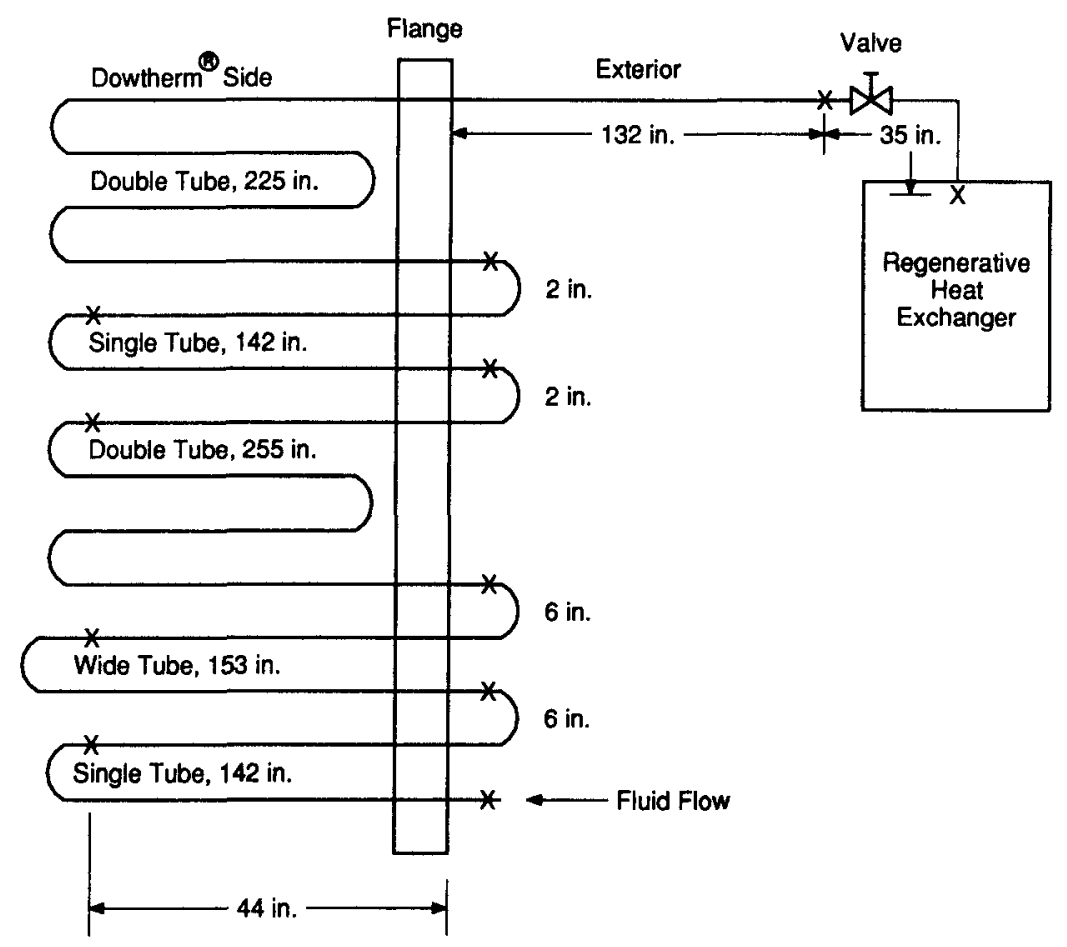

FIGURE 2.7 Schematic Diagram of Evaporator, Showing Thermocouple Locations

A pulsation damper is included in the loop following the metering pump to smooth out the pressure fluctuations from the main metering pump. A Pulsatrol 38 damper constructed of stainless steel, it uses a viton diaphragm. Viton has been found to be compatible with toluene in the temperature range of interest for this study. The damper has been modified to pressurize the diaphragm with toluene vapor. Inert gases used to pressurize the damper in previous experiments were found to permeate through the diaphragm and cause unacceptable increases in condenser pressure.

\subsubsection{Liquid- and Vapor-Sampling Stations}

Figure 2.8 shows schematic diagrams of the sampling stations for liquids and for noncondensable vapors. Periodic withdrawal of both liquid and noncondensable-vapor samples is required to monitor the fluid degradation during a test run. Precautions are taken to prevent contamination of the organic fluids during the sample withdrawal process. The liquid sampling station is located between the condenser and the pump. The liquid sampling procedure is simple and requires a 0.25 -in.-O.D., 3-in.-long glass sample tube and a vacuum pump. After the tube is attached to the sample port and

*"Teflon" and "Viton" are trademarks of E.I. DuPont de Nemours and Co., Wilmington, Del. 


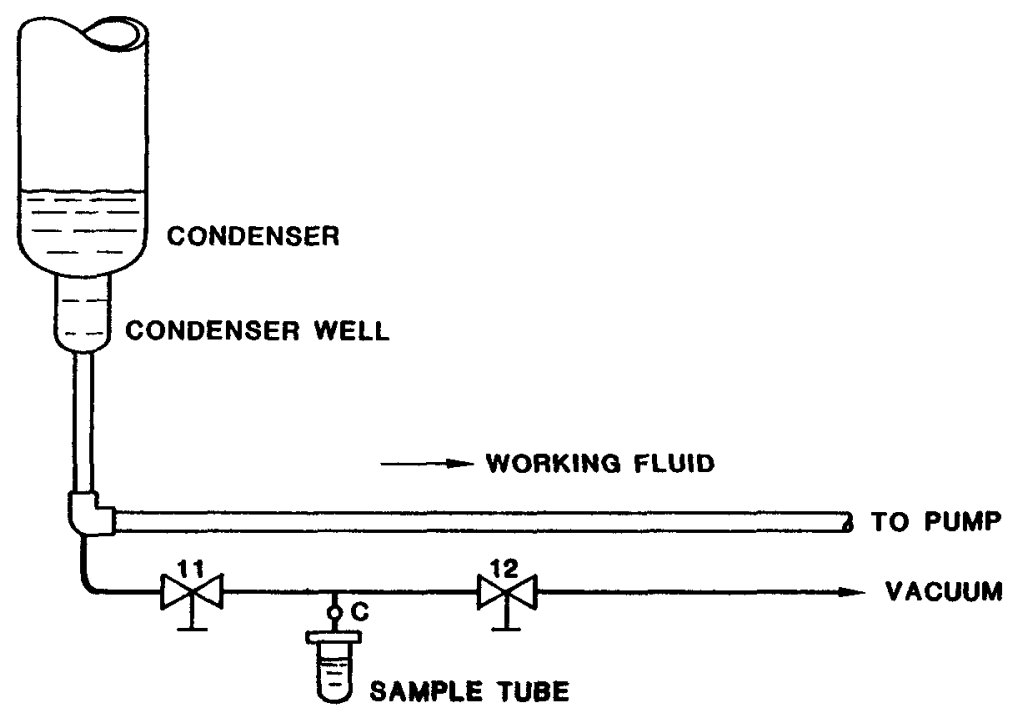

a. Liquid Sampling Station

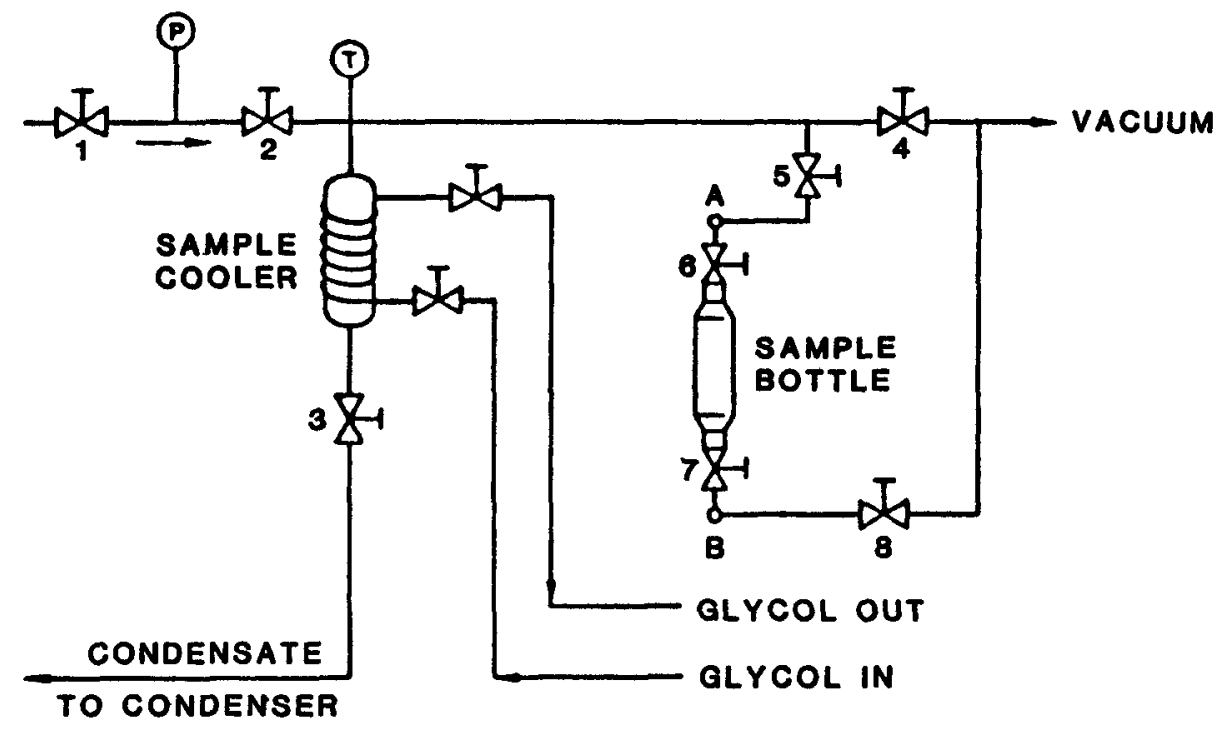

b. Noncondensable-Vapor Sampling Station

FIGURE 2.8 Schematic Diagrams of Sampling Stations

evacuated, the vacuum valve is closed and the sample valve opened to fill the sample tube. The sample valve is then closed, and the sample tube is removed from the sample port. Two such samples are taken from the loop at each sampling time; the first sample is discarded to remove any stagnant fluid that might be present in the lines leading to the sampling valve.

The noncondensable samples are drawn through the top of the condenser into a sample cooler. A $150-\mathrm{mL}$ SS sampling cylinder is used to draw noncondensable samples from the sample cooler. To obtain a gas sample, a sampling cylinder is attached to the 
sample cooler and evacuated. After the sample cooler has been filled with vapor and noncondensable gas from the condenser, the sample cooler is valved off and cooled for one hour to condense whatever vapor is present. The valve between the sample cooler and the sample cylinder is then opened briefly to obtain the sample for analysis.

\subsubsection{Toluene Degasification Procedure}

Before the toluene is loaded into the loop, dissolved air must be removed; otherwise, dissolved oxygen would react with the toluene during loop operation to produce benzaldehyde and give an unrealistic measurement of the degradation rate. The toluene is loaded into a vessel, where it is frozen with liquid nitrogen; the gas remaining in the vessel is removed with a vacuum pump. After valving off the vacuum pump, the toluene is allowed to melt and release the dissolved gases into the vessel. Three freezeevacuate-thaw cycles are performed. The pressure in the vessel is monitored at the end of each thaw to ensure satisfactory removal of the dissolved air.

\subsection{FLUID HEATING SECTION}

Heat is added to the fluids in a pressure vessel enclosing the evaporator/superheater tube bundle. In this vessel, Dowtherm $A$ is heated and vaporized using three Watlow electrical immersion heaters. Heat is transferred to the working fluid by condensing the Dowtherm vapor on the outside surfaces of the evaporator/superheater coil. The test loop uses three 480-V (alternating current), 7.5-kW heaters of the 2-in. by 11-1/2 National Pipe Thread (NPT) screw-plug type; each heater has three elements, for a total of nine heating elements. The heaters have a power density rating of $23 \mathrm{~W} / \mathrm{in}^{2}$ with the steel sheath at $343^{\circ} \mathrm{C}\left(650^{\circ} \mathrm{F}\right)$. One heater is wired to provide $7.5 \mathrm{~kW}$ of heat in switchable, $2.5-\mathrm{kW}$ increments. The other two heaters are connected to a Barber-Coleman $527 \mathrm{Z}$ temperature controller operating at $240 \mathrm{~V}$ (alternating current) to provide an additional $0-3.75 \mathrm{~kW}$ of heat.

The pressure vessel is constructed of 16-in.-diameter, 50-in.-long, type 304 SS pipe. It is designed to withstand $800^{\circ} \mathrm{F}$ at 150 psia. One end is closed by a welded cap, and the other end is closed by a flange through which the evaporator/superheater coils pass. The pressure vessel is fitted with a 150-psi rupture disk, a low-liguid-level alarm, a fluid drain, a fluid fill connection, and thermocouples. The system is designed to provide $700^{\circ} \mathrm{F}$ toluene vapor at the maximum allowable temperature of $720^{\circ} \mathrm{F}$ for Dowtherm ${ }^{\circledR} \mathrm{A}$.

\subsection{HEAT REJECTION SYSTEM}

The heat rejection system consists of a plastic coolant-storage tank, a heatexchange coil, and a variable-speed gear pump. The cooling water is drawn from the storage tank by the pump, circulates through the condenser (where it removes heat from the loop), and returns to the storage tank. Chilled water circulating through the heatexchange coil removes heat from the storage tank, maintaining its temperature at approximately $20^{\circ} \mathrm{C}$. A potentiometer on the control panel adjusts the gear-pump speed to maintain the desired condenser pressure. 


\subsection{INSTRUMENTATION, CONTROLS, AND DATA-ACQUISITION SYSTEMS}

Temperatures at various locations in the loop are measured by using type-E Chromel/Constantan thermocouples, and pressures are measured using Sensotech $\mathrm{T}$ - and Z-series strain-gauge pressure transducers. Mechanical gauges are installed to measure pressures at other locations and to verify the pressure transducer readings. The signals from the thermocouples and pressure transducers are recorded by a Digistrip II data logger and are monitored by the safety circuit, which automatically turns the loop off if a malfunction is detected.

Rough control of the heat input to the loop is achieved by manually switching three of the $480-\mathrm{V}, 2.5-\mathrm{kW}$ heater elements. Fine control is achieved by a BarberColeman $527 \mathrm{Z}$ proportional controller acting on the remaining six heater elements. The controller and its heater elements operate on $240-\mathrm{V}$, single-phase power to provide an additional $0-3.75 \mathrm{~kW}$ of heat. This arrangement provides four overlapping ranges of heat: 0-3.75 kW, 2.5-6.25 kW, 5.0-8.75 kW, and 7.5-11.25 kW. The temperature controller senses the toluene vapor temperature immediately upstream of the pressure-reduction valve with a type- $K$ thermocouple.

The condenser pressure is controlled by manually adjusting the coolant flow rate. The evaporator pressure is controlled by manually adjusting the expansion valves. The toluene flow rate is controlled by manually adjusting the metering pump stroke.

A Digistrip II, 48-channel data logger is used to collect and record all temperature, pressure, and flow-rate data at half-hour intervals. In addition to its datalogging functions, the Digistrip II sends its measurements for each 20-s period to an Apple II+ computer by means of an RS-232C line. The computer was installed about $100 \mathrm{~h}$ after the second test began and continued recording data until the end of the last (fourth) test. The computer is programmed to (1) accept data from one or two Digistrip data loggers, each transmitting data for each 20-s period; (2) display all of the measurements on the screen; (3) transmit data at half-hour intervals to a digital tape recorder; (4) store up to eight sets of data (taken at half-hour intervals) in buffers; and (5) transmit the contents of those buffers to a dial-up modem, so that the loop can be monitored from a remote location.

A two-channel strip chart recorder (Lenseis 6502) continuously monitors the evaporator outlet temperature and condenser pressure. 


\section{ANAL YTICAL TECHNIQUES AND PROCEDURES}

In the present investigation, both liquid and gaseous (noncondensable-vapor) samples are periodically collected and analyzed. Components of the gaseous samples are identified and quantified by mass-spectrometric analysis. The approach used for the chemical analysis of liquid samples is to first identify the degradation products and then determine the concentration of each degradation product in each toluene sample; the sum of degradation-product concentrations is considered to be the total degradation for each sample. Qualitative identification is based upon gas chromatography/mass spectroscopy (GC/MS). Quantitative analysis of the concentration of degradation products is based upon gas chromatographic analysis using a flame ionization detector (FID). The data generated by the gas chromatograph were analyzed using custom-written sof tware developed at Argonne for this project. The equipment used and the type of data obtained are described below.

\subsection{MASS-SPECTROMETRIC GAS ANALYSIS}

The gaseous (noncondensable-vapor) samples are collected from the condenser in 150-mL SS cylinders and analyzed with a modified Consolidated Engineering Co. CEC21620 /gas mass spectrometer. The sample cylinder is connected to the spectrometer, and the air between the two is pumped out. After a satisfactory vacuum is attained, the sample container is opened to the mass spectrometer. The sample is allowed to expand to 100 torr pressure in the inlet and a $3-\mathrm{mL}$ calibrated volume; the $3 \mathrm{~mL}$ is further expanded in a $3000-\mathrm{mL}$ reservoir and introduced into the spectrometer.

Gas molecules are ionized by bombardment with $70-\mathrm{eV}$ electrons, and the ions are injected into a permanent magnetic field, where they are sorted according to mass number:

$$
\mathrm{M} / \mathrm{e}=\mathrm{KH}^{2} / \mathrm{V}
$$

where $M$ is the mass of the ion, $e$ is the charge of an electron, $K$ is a calibration constant, $\mathrm{H}$ is the magnetic field, and $\mathrm{V}$ is the applied voltage. The focused ions impinge on a collector, where they give up their charge, and the signal thus generated is amplified and delivered to a strip-chart recorder. Every molecular species has a unique spectrum of fragments, isotopic ions, and multiply charged ions that identifies it. A tabulation of ion peak height at each mass number relative to the largest (base) peak is obtained from a spectrum of the pure gas. Since the height of the base peak is proportional to the pressure of the gas in the spectrometer, the spectrum is made at known pressure to determine the sensitivity coefficient (i.e., peak height/pressure).

In analyzing a gas mixture, therefore, the first step after reloading a spectrum and measuring the peak heights is to sort out the components by their patterns. The 
second step is to ascertain the true height of the base peak of each component $\mathbf{x}$ and to calculate its partial pressure $\mathrm{pp}_{\mathbf{x}}$ :

$$
\mathrm{pp}_{\mathrm{x}}=\mathrm{h}_{\mathrm{x}} / \mathrm{s}_{\mathrm{x}}
$$

where $h_{x}$ is the peak height of component $x$ and $s_{x}$ is the instrument sensitivity for that component. The percentage of each component $x$ is obtained by summing the partial pressures of all the components and normalizing:

$$
\mathrm{f}_{\mathrm{x}}=\frac{\mathrm{pp_{ \textrm {x } }}}{\sum_{\mathrm{i}} \mathrm{pp}_{\mathrm{i}}} \times 100
$$

where $\mathrm{pp}_{i}$ is the partial pressure of component $i$ and $f_{x}$ is the quantity of component $x$, expressed as a percentage of the total.

The accuracy of analysis depends on various factors, including the accuracy of pressure measurements for the standard, the stability of the electronic components, and the nature of the sample. If two or more components - such as $\mathrm{N}_{2}, \mathrm{CO}$, and $\mathrm{C}_{2} \mathrm{H}_{4}$ have the same base peaks, the sorting out by pattern becomes more difficult and less reliable. For relatively simple mixtures, an overall accuracy of about $\pm 2 \%$ can be achieved. For complex mixtures, $\pm 5 \%$ accuracy is more realistic.

\subsection{GAS CHROMATOGRAPHY/MASS SPECTROSCOPY}

Degraded samples of toluene are used to establish initial conditions applicable for both gas chromatography (GC) and GC/MS analysis. After conditions are optimized, GC/MS analysis is used to identify degradation products. We have found that the concentrations of the different degradation products vary substantially with temperature, but very few additional degradation products are formed at the higher temperatures compared with products formed at the lower temperatures.

Bibenzyl and six other classes of aromatic degradation products were identified. The classes are alkylbenzenes, multiring aromaties, substituted styrenes, dimethylbiphenyls (C2-BIP), C1-diphenylmethanes, and methyl and trimethyl biphenyls (C1-BIP, C3-BIP). In addition, biphenyl is present in much lower concentration. For the temperatures studied, bibenzyl is the major degradation product. Measurable but insignificant amounts of benzaldehyde were also formed from (1) air that remained in the loop after evacuation but before the initial charge of toluene was loaded, (2) air incursion into the loop during testing, (3) oxygen-bearing impurities present in the toluene before the tests began, and (4) small quantities of dissolved air remaining in the toluene after the triple freeze-thaw procedure for removing dissolved gases was completed.

A Hewlett-Packard (HP) 5984 GC/MS instrument is used with SPEED sof tware. Mass spectra are obtained using electron impact (EI). The molecular ions were present for virtually all degradation products, which facilitated identification. Individual geometrical isomers could not be distinguished, because the mass spectra were virtually identical; hence, geometrical isomers are not reported (e.g., C1-biphenyl is used as the 
name for all three geometrical isomers of the compound, 1-methylbiphenyl, 2-methylbiphenyl, and 3-methylbiphenyl).

Following GC/MS identification of the components, the retention indexes are calculated for each component by a computer program. A data file, consisting of the retention index and the name for each component, is entered into the PE 3600 laboratory computer. This file is updated for any new components identified in subsequent degradation samples. Customized software written for the program accesses the data file and makes preliminary identifications based on its contents. All identifications were verified before being included in this report.

\subsection{GAS CHROMATOGRAPHY}

All liquid samples are analyzed on an HP 5880A gas chromatograph equipped with an FID, a split/splitless injector, and a cartridge tape unit (CTU) to provide a quantitative measure of the nonvolatile organic degradation products formed. All injections are made split with a $30-\mathrm{mL} / \mathrm{min}$ split flow. The sample is injected undiluted. The GC conditions used for the analysis are shown in Table 3.1. Gas chromatograph run reports are stored on the CTU for further processing. The instrument has an interface with a Perkin Elmer (PE) Sigma 7500 chromatography data station, which is used to store the chromatogram. The software package used, Chromatographics 3, contains exceptional replotting capabilities.

The GC report, consisting of retention times and peak areas, is transmitted via data communication interface (DCI) on the $5880 \mathrm{~A}$ to a $\mathrm{PE} 3600$ laboratory computer, where it is stored on disk. Customized software was written to provide reports consisting of preliminary identification, retention index (based on an aromatic standard), and concentration (based on user-set response factors). These reports are both printed and stored on disk. The PE 3600 and 7500 laboratory computers both have an interface with the Argonne Vax computers, so results can be transferred to and stored on any other system. The Model 7500 computer can read Model 3600 disks, so the data generated on the older computer can be used on the newer system.

An analysis standard reflecting the nature of the degradation products was prepared (see Table 3.2). The standard consists of substituted benzenes, biphenyl,
TABLE 3.1 Conditions Employed for Gas Chromatography/Flame Ionization Detection and Gas Chromatography/Mass Spectroscopy Analysis $^{\mathrm{a}}$

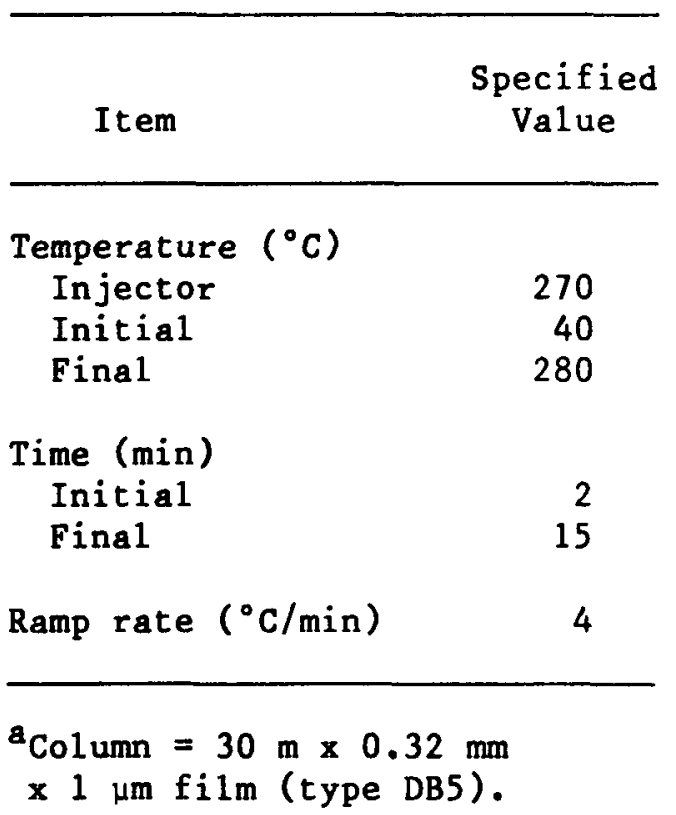


TABLE 3.2 Components of the Standard

\begin{tabular}{|c|c|c|c|c|}
\hline Standard & $\begin{array}{l}\text { Conc. } \\
\text { (ppm) }\end{array}$ & $\begin{array}{l}\text { Retention } \\
\text { Time (min) }\end{array}$ & $\begin{array}{l}\text { Response } \\
\text { Factor }\end{array}$ & $\begin{array}{l}\text { Time Range } \\
\text { (min) }\end{array}$ \\
\hline Benzene & 22.2 & 2.64 & $\mathrm{RF}(1)$ & $<9$ \\
\hline Ethylbenzene & 16.5 & 7.79 & $\mathrm{RF}(1)$ & $<9$ \\
\hline p-Xylene & 7.9 & 8.09 & $\mathrm{RF}(1)$ & $<9$ \\
\hline o-xylene & 22.8 & 8.97 & $\mathrm{RF}(1)$ & $<9$ \\
\hline Nonane & 39.8 & 9.24 & Not used & Not used \\
\hline Propyl benzene & 10.6 & 11.37 & $\mathrm{RF}(2)$ & $9-20$ \\
\hline $\begin{array}{l}\text { Trimethyl- } \\
\text { benzene }\end{array}$ & 23.6 & 12.99 & $\mathrm{RF}(2)$ & $9-20$ \\
\hline Naphthalene & 61.8 & 20.69 & $\mathrm{RF}(3)$ & $20-30$ \\
\hline Biphenyl & 19.1 & 27.88 & $\mathrm{RF}(3)$ & $20-30$ \\
\hline Bibenzyl & 21.5 & 32.61 & $\mathrm{RF}(4)$ & $30-40$ \\
\hline $\begin{array}{l}3,3 \text {-Dimethyl- } \\
\text { bi phenyl }\end{array}$ & 7.6 & 34.76 & $\operatorname{RE}(4)$ & $30-40$ \\
\hline $\begin{array}{l}4,4^{\prime} \text {-Dimethyl- } \\
\text { bi phenyl }\end{array}$ & 22.0 & 35.34 & $\operatorname{RE}(4)$ & $30-40$ \\
\hline Phenanthrene & 18.8 & 40.44 & $\mathrm{RF}(5)$ & $>40$ \\
\hline
\end{tabular}

bibenzyl, two substituted C2-biphenyls, and the retention index standards (benzene, naphthalene, and phenanthrene). An aromatic retention index is used because the degradation products are all aromatic, and as the column ages over the course of the project any retention-time drift would be equal for both the degradation products and the standard. That would not be the case if the Kovats alkane retention index system were used. In the aromatic system, the retention indexes of the three standards are benzene, 200; naphthalene, 400 ; and phenanthrene, 600 .

The analysis standard is run each day a degraded toluene sample is analyzed. Customized software calibrates the standard immediately after the run and provides a check for instrument drift. Instrument problems are corrected immediately before samples are analyzed, and the correction is verified by rerunning the analysis standard. The response factors calculated by the computer are stored on disk and used in the calculation of the concentration of the components in the sample.

After each sample is run, the report is transferred to the PE 3600 laboratory computer, where the retention index (RI) program is run. This specially written software produces the report on the sample. It first calculates the retention indexes of all components in the sample. The program then reads the standard response-factor file and averages the response factors of standards in specified retention-time ranges. The concentrations of components in parts per million (ppm) are then calculated using the appropriate response factor. Finally, components are identified from the RI file; these results are printed and stored on disk. The toluene itself is used as the internal standard, and the peak areas are normalized for toluene, so the total concentration of toluene and 
its degradation products is unity $(1,000,000 \mathrm{ppm})$. This eliminates any problems with sample loading. All individual reports on samples are hand-verified, and corrections are made using the line editor. 


\section{SUMMARY OP DYNAMIC LOOP OPERATIONS}

Approximately $3800 \mathrm{~h}$ of toluene testing in four test runs, ranging from 600 to $677^{\circ} \mathrm{F}$, are summarized in this section. During these test runs, vapor temperatures and pressure at the evaporator/superheater exit, condenser pressure and temperatures of the condensate, and temperatures of vapor and liquids at the economizer inlet and exit ends were recorded every half hour. The maximum and minimum cycle operation temperatures and pressures were analyzed for each of the runs to verify relatively steady-state operation of the dynamic loop. A summary of these data for each of the runs is presented in Table 4.1, and the following subsections describe the operations. Appendix A provides detailed information on temperatures and pressures on a daily basis for each of the tests.

\subsection{TEST RUN NO. $1\left(840 \mathrm{~h}\right.$ at $\left.635^{\circ} \mathrm{F}\right)$}

The nominal operating conditions for this run were $635^{\circ} \mathrm{F}$ and 160 psia at the evaporator/superheater exit, 18 psia condenser pressure, and $120^{\circ} \mathrm{F}$ subcooled condensate temperature.* The actual average operating temperature was $635.3^{\circ} \mathrm{F}$, with minimum and maximum values of 625.2 and $652.3^{\circ} \mathrm{F}$, respectively. The minimum and maximum values of the pressure at the evaporator/superheater exit were 149.7 and 163.4 psia, respectively, with an overall average value of 158.9 psia. The condenser pressure was between 15.11 and 22.48 psia, with an overall average value of 17.42 psia.

Further insight into loop operations for this run can be gained by examining Table 4.2, which was derived from the operations $\log$ of the test. The most serious problems encountered were unplanned shutdowns due to coolant pump seizures at 483 and $485 \mathrm{~h}$ elapsed time. After the pump was repaired, samples were drawn at $504 \mathrm{~h}$ elapsed time to determine whether any air had entered the loop. An increase of benzaldehyde in the 504-h sample shows that a small quantity of air entered the loop during the downtime, but the amount is considered small enough that the test remains valid. The 168-h sample shows a smaller increase in benzaldehyde after a decrease of condenser pressure to 15.11 psia averaged over several pump strokes; during the pump suction stroke, the pressure was probably subatmospheric. One brief power outage, lasting less than one minute, occurred at $433.5 \mathrm{~h}$ elapsed time during a thunderstorm. Temperature and pressure data at 600.5 and $641 \mathrm{~h}$ elapsed time were unavailable, due to a data logger malfunction and running out of paper, respectively. The digital tape recorder was not installed as a backup to the paper printout until test no. 2 was under way. After completion of the test some key thermocouples were checked with an independent instrument, and the readings were found to disagree with the data logger readings. This discrepancy was traced to a stuck relay in the data logger and to the fact that all of the

\footnotetext{
*Results of the $635^{\circ} \mathrm{F}$ test run are presented first because this run preceded the 600 , 650 , and $677^{\circ} \mathrm{F}$ test runs chronologically. The $635^{\circ} \mathrm{F}$ run also differed substantially from the other runs with respect to evaporator pressure.
} 
TABLE 4.1 Summary of Test Conditions

\begin{tabular}{|c|c|c|c|c|c|c|c|c|c|c|}
\hline \multirow{2}{*}{$\begin{array}{l}\text { Run } \\
\text { No. }\end{array}$} & \multirow{2}{*}{$\begin{array}{l}\text { Elapsed } \\
\text { Time (h) }\end{array}$} & \multicolumn{3}{|c|}{ Temp. $\left({ }^{\circ} \mathrm{F}\right)$} & \multicolumn{3}{|c|}{$\begin{array}{c}\text { Evaporator } \\
\text { Pressure (psia) } \\
\end{array}$} & \multicolumn{3}{|c|}{$\begin{array}{c}\text { Condenser } \\
\text { Pressure (psia) }\end{array}$} \\
\hline & & Avg. & Min. & Max. & Avg. & Min. & Max. & Avg. & Min. & Max. \\
\hline $\begin{array}{l}1 \\
2 \\
3 \\
4\end{array}$ & $\begin{array}{r}840 \\
1006 \\
1006 \\
1006\end{array}$ & $\begin{array}{l}635.3 \\
599.7 \\
649.7 \\
677.5\end{array}$ & $\begin{array}{l}625.2 \\
595.2 \\
635.8 \\
674.0\end{array}$ & $\begin{array}{l}652.3 \\
603.5 \\
652.0 \\
679.2\end{array}$ & $\begin{array}{l}158.89 \\
493.89 \\
497.94 \\
500.41\end{array}$ & $\begin{array}{l}149.70 \\
450.80 \\
482.80 \\
481.00\end{array}$ & $\begin{array}{l}163.40 \\
509.80 \\
516.60 \\
517.30\end{array}$ & $\begin{array}{l}17.42 \\
17.26 \\
17.82 \\
17.76\end{array}$ & $\begin{array}{l}15.11 \\
10.94 \\
14.73 \\
15.81\end{array}$ & $\begin{array}{l}22.48 \\
18.68 \\
19.01 \\
19.49\end{array}$ \\
\hline
\end{tabular}


TABLE 4.2 Summary of Events for Test No. $1\left(635^{\circ} \mathrm{F}\right)$

\begin{tabular}{|c|c|}
\hline Elapsed Time Th $^{\mathrm{a}}$ & Description of Event \\
\hline $\begin{array}{c}\text { Sample-Taking } \\
45 \\
168 \\
338 \\
504 \\
649 \\
840\end{array}$ & $\begin{array}{l}\text { First samples } \\
\text { Second samples } \\
\text { Third samples } \\
\text { Fourth samples } \\
\text { Fifth samples } \\
\text { Sixth samples (test completed) }\end{array}$ \\
\hline $\begin{array}{l}\text { Other Events } \\
49 \\
51.5 \\
67 \\
99 \\
164.5 \\
433.5 \\
483 \\
485 \\
572.5 \\
600.5 \\
641\end{array}$ & $\begin{array}{l}\text { Ad just fluid pump and evaporator temperature. } \\
\text { Ad just condenser pressure. } \\
\text { Adjust condenser pressure and evaporator } \\
\text { temperature. } \\
\text { Ad just condenser pressure. } \\
\text { Ad just fluid pump. } \\
\text { Power outage ( } 1 \text { min) during thunderstorm. } \\
\text { Shutdown due to coolant pump seizure (pump repaired } \\
\text { and loop restarted after } 19 \text { h downtime). } \\
\text { Shutdown due to coolant pump seizure (pump repaired } \\
\text { and loop restarted after } 2 \text { h downtime). } \\
\text { Adjust condenser pressure. } \\
\text { Data logger malfunction due to air-conditioning } \\
\text { failure ( } 1.5 \text { h of temperature data unavailable). } \\
\text { Data logger out of paper ( } 5.5 \text { h of temperature } \\
\text { data unavailable). }\end{array}$ \\
\hline
\end{tabular}

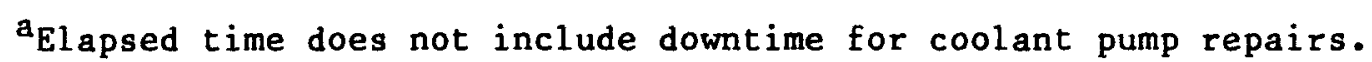

thermocouples were the grounded type. After repairing the data logger, we replaced four of the grounded-type thermocouples with the ungrounded type for easier detection of the stuck-relay problem. The relay problem did not recur during the remaining tests. A means of correcting the temperature readings was found, and the corrected temperatures are used in this report.

Additional information can be gained from Table 4.3, which summarizes temperatures and pressures in the intervals between samples; two additional time intervals (terminated by the unplanned shutdowns for coolant pump repair) are shown in the table. The average temperatures for all but one time interval were within $5^{\circ} \mathrm{F}$ of the nominal temperature. Near the end of the 45-168-h time interval (at $164.5 \mathrm{~h}$ ), the stroke of the fluid pump was adjusted to obtain better control of the temperature. Only minimum temperatures for the 45-168- and 482-484-h intervals and maximum temperatures for the 168-338- and 649-840-h intervals differed from the nominal 
TABLE 4.3 Summary of Temperatures and Pressures in Intervals between Samples for Test No. $1\left(635^{\circ} \mathrm{F}\right)$

\begin{tabular}{|c|c|c|c|c|c|c|c|c|c|}
\hline \multirow{2}{*}{$\begin{array}{l}\text { Interval } \\
\quad(\mathrm{h})\end{array}$} & \multicolumn{3}{|c|}{ Temp. $\left({ }^{\circ} \mathrm{F}\right)$} & \multicolumn{3}{|c|}{$\begin{array}{c}\text { Evaporator } \\
\text { Pressure (psia) }\end{array}$} & \multicolumn{3}{|c|}{$\begin{array}{c}\text { Condenser } \\
\text { Pressure (psia) }\end{array}$} \\
\hline & Avg. & Min. & Max. & Avg. & Min. & Max. & Avg. & Min. & Max. \\
\hline $\begin{array}{c}0-45 \\
45-168 \\
168-338 \\
338-482^{a} \\
482-484^{b} \\
484-504 \\
504-649^{c} \\
649-840\end{array}$ & $\begin{array}{l}636.8 \\
629.5 \\
635.9 \\
636.7 \\
631.7 \\
636.8 \\
636.1 \\
636.4\end{array}$ & $\begin{array}{l}631.4 \\
625.2 \\
631.7 \\
632.8 \\
627.4 \\
630.0 \\
631.7 \\
633.3\end{array}$ & $\begin{array}{l}639.8 \\
638.6 \\
652.3 \\
640.7 \\
635.4 \\
639.8 \\
640.0 \\
651.6\end{array}$ & $\begin{array}{l}160.16 \\
160.50 \\
160.10 \\
156.94 \\
158.03 \\
160.44 \\
158.31 \\
158.20\end{array}$ & $\begin{array}{l}157.50 \\
157.50 \\
156.70 \\
149.70 \\
154.60 \\
157.30 \\
156.70 \\
155.70\end{array}$ & $\begin{array}{l}161.60 \\
163.40 \\
162.60 \\
160.50 \\
159.90 \\
163.10 \\
159.80 \\
160.60\end{array}$ & $\begin{array}{l}17.65 \\
17.23 \\
17.57 \\
17.47 \\
17.92 \\
17.59 \\
17.69 \\
17.08\end{array}$ & $\begin{array}{l}17.08 \\
15.11 \\
17.10 \\
16.87 \\
16.23 \\
16.59 \\
16.58 \\
15.99\end{array}$ & $\begin{array}{l}18.03 \\
18.09 \\
18.09 \\
18.39 \\
19.09 \\
18.19 \\
22.48 \\
18.46\end{array}$ \\
\hline Overall & 635.3 & 625.2 & 652.3 & 158.89 & 149.70 & 163.40 & 17.42 & 15.11 & 22.48 \\
\hline
\end{tabular}

${ }^{a}$ Loop down for $19 \mathrm{~h}$ at the end of this time period.

$b_{\text {Loop down for }} 2 \mathrm{~h}$ at the end of this time period.

${ }^{c}$ Seven hours of data unavailable in this time period. 
temperature of $635^{\circ} \mathrm{F}$ by more than $5^{\circ} \mathrm{F}$. Average evaporator pressures were within 5 psi of the nominal 160 psia (absolute pressure), and only the minimum pressure for 338-482 $h$ differs from the nominal value by more than 5 psi. Average condenser pressures are all within 1 psi of the nominal 18 psia. Only the maximum pressure for 504-649 $\mathrm{h}$ differs from the nominal value by more than 3 psi.

\subsection{TEST RUN NO. $2\left(1006 \mathrm{~h}\right.$ at $\left.600^{\circ} \mathrm{F}\right)$}

For test run no. 2, the nominal conditions were $600^{\circ} \mathrm{F}$ evaporator temperature, 500 psia evaporator pressure, and 18 psia condenser pressure. The actual average evaporator temperature was $599.7^{\circ} \mathrm{F}$, with a minimum of $595.2^{\circ} \mathrm{F}$ and a maximum of $603.5^{\circ} \mathrm{F}$. The average evaporator pressure was $493.9 \mathrm{psia}$, with a minimum of $450.8 \mathrm{psia}$ and a maximum of 509.8 psia. The average condenser pressure was 17.26 psia, with a minimum of 10.94 psia and a maximum of 18.68 psia.

Table 4.4 gives the elapsed times at which the samples were drawn and summarizes events that were recorded in the operations log. At $83 \mathrm{~h}$ elapsed time the data logger ran out of paper, making $10 \mathrm{~h}$ of temperature and pressure data unavailable; this occurred before the digital tape recorder was installed as a backup for the paper printouts. At $169.5 \mathrm{~h}$ a momentary power outage while some equipment was being installed near the loop caused an unplanned shutdown of less than one minute duration. The most serious event occurred at about $425 \mathrm{~h}$, when the evaporator pressure reading began to drift because of a loose connection. Repairing the connection restored the accuracy of the pressure measurement.

TABLE 4.4 Summary of Events for Test No. $2\left(600^{\circ} \mathrm{F}\right)$

Elapsed Time ( $h$ ) Description of Event

$\begin{array}{cl}\text { Sample-Taking } & \text { First samples } \\ 23 & \text { Second samples } \\ 266 & \text { Third samples } \\ 655 & \text { Fourth samples } \\ 763 & \text { Fifth samples } \\ 938 & \text { Sixth samples } \\ 1006 & \text { Seventh samples (test completed) } \\ \text { Other Events } & \text { Data logger out of paper (10 h of temperature } \\ 83 & \text { data unavailable). } \\ 169.5 & \text { Momentary power outage due to installation of } \\ 262.5 & \text { equipment nearby (no loss of data). } \\ 425 & \text { Data logger overheated (no loss of data). } \\ & \text { Evaporator pressure reading drifted for } 4 \mathrm{~h} \text { due } \\ & \text { to a loose connection; connection was repaired. }\end{array}$


Table 4.5 summarizes the temperatures and pressures in the intervals between the taking of gaseous and liquid samples. All average, minimum, and maximum temperatures for all intervals were within $5^{\circ} \mathrm{F}$ of the nominal $600^{\circ} \mathrm{F}$. Evaporator pressures tended to be somewhat lower than the nominal 500 psia, but all averages except those from the first $23 \mathrm{~h}$ were within $10 \mathrm{psi}$ of the nominal value. All of the minima differed from the nominal value by more than 10 psi, but all of the maxima were within $10 \mathrm{psi}$ of the nominal value. All of the condenser pressures (average, minimum, and maximum) for all intervals were within 3 psi of the nominal 18.0 psia, except for the minimum pressure at startup (0-23 h). This was a relatively uneventful test run.

\subsection{TEST RUN NO. $3\left(1006 \mathrm{~h}\right.$ at $\left.650^{\circ} \mathrm{F}\right)$}

For test run no. 3, the nominal conditions were $650^{\circ} \mathrm{F}$ evaporator temperature, 500 psia evaporator pressure, and 18 psia condenser pressure. These conditions differed from the nominal conditions of test no. 2 only in the evaporator temperature. For this run the actual average evaporator temperature was $649.7^{\circ} \mathrm{F}$, with a minimum of $635.8^{\circ} \mathrm{F}$ and a maximum of $652.0^{\circ} \mathrm{F}$. The average evaporator pressure was $497.9 \mathrm{psia}$, with a minimum of 482.8 psia and a maximum of 516.6 psia. The average condenser pressure was 17.82 psia, with a minimum of 14.73 psia and a maximum of 19.01 psia.

Table 4.6 gives the elapsed times at which the samples were drawn and summarizes events that were recorded in the operations log. As the table shows, the condenser and evaporator pressures required more frequent adjustment than were needed in the tests at lower temperatures. This is probably because more degradation occurs at the higher temperature, although the degradation rate is quite low. In several instances the data logger ran out of paper, but the tape recorder provided backup. At $551 \mathrm{~h}$, the cooling system was temporarily switched to domestic water while the chilled water system was being serviced. At $616 \mathrm{~h}$, the cooling system was switched back to the chilled water supply. The changes of the cooling system did not affect the test.

Table 4.7 summarizes the temperatures and pressures in the intervals between taking of gaseous and liquid samples. All temperatures except the minimum temperature at the end of the test are within $5^{\circ} \mathrm{F}$ of the nominal $650^{\circ} \mathrm{F}$. Although the average evaporator pressure of 497.9 psia is close to the nominal pressure of 500 psia, all of the pressure minima and three of the pressure maxima (for 19-115, 115-282, and 619-786 $h$ ) differed from the nominal value by more than $10 \mathrm{psi}$. This situation is similar to that of test no. 2. All of the condenser pressures were within 3 psi of the nominal 18 psia.

\subsection{TEST RUN NO. $4\left(1006 \mathrm{~h}\right.$ at $\left.677^{\circ} \mathrm{F}\right)$}

Test run no. 4, with a nominal evaporator temperature of $677^{\circ} \mathrm{F}$, nominal evaporator pressure of $500 \mathrm{psia}$, and nominal condenser pressure of $18 \mathrm{psia}$, differed from test runs nos. 2 and 3 only in the evaporator temperature. The actual average evaporator temperature was $677.5^{\circ} \mathrm{F}$, with a minimum of $674.0^{\circ} \mathrm{F}$ and a maximum of $679.2^{\circ} \mathrm{F}$. The average evaporator pressure was 500.4 psia, with a minimum of 481.0 psia and a 
TABLE 4.5 Summary of Temperatures and Pressures in Intervals between Samples for Test No. $2\left(600^{\circ} \mathrm{F}\right)$

\begin{tabular}{|c|c|c|c|c|c|c|c|c|c|}
\hline \multirow{2}{*}{$\begin{array}{l}\text { Interval } \\
(\mathrm{h})\end{array}$} & \multicolumn{3}{|c|}{ Temp. $\left({ }^{\circ} \mathrm{F}\right)$} & \multicolumn{3}{|c|}{$\begin{array}{c}\text { Evaporator } \\
\text { Pressure (psia) }\end{array}$} & \multicolumn{3}{|c|}{$\begin{array}{c}\text { Condenser } \\
\text { Pressure (psia) }\end{array}$} \\
\hline & Avg. & Min. & Max. & Avg. & Min. & Max. & Avg. & Min. & Max. \\
\hline $\begin{array}{c}0-23 \\
23-266^{a} \\
266-455 \\
455-623 \\
623-766 \\
766-938 \\
938-1006\end{array}$ & $\begin{array}{l}597.4 \\
598.7 \\
599.7 \\
600.2 \\
600.2 \\
600.4 \\
600.1\end{array}$ & $\begin{array}{l}595.2 \\
597.7 \\
598.7 \\
599.1 \\
599.4 \\
599.3 \\
599.4\end{array}$ & $\begin{array}{l}603.5 \\
601.2 \\
600.9 \\
601.1 \\
601.0 \\
601.4 \\
600.7\end{array}$ & $\begin{array}{l}489.86 \\
493.77 \\
494.75 \\
493.16 \\
491.53 \\
496.74 \\
492.78\end{array}$ & $\begin{array}{l}483.70 \\
486.20 \\
450.80 \\
486.60 \\
482.40 \\
483.80 \\
470.50\end{array}$ & $\begin{array}{l}508.10 \\
503.20 \\
509.80 \\
501.00 \\
505.70 \\
507.00 \\
501.70\end{array}$ & $\begin{array}{l}17.36 \\
17.18 \\
17.14 \\
17.72 \\
17.49 \\
17.07 \\
16.78\end{array}$ & $\begin{array}{l}10.94 \\
14.04 \\
15.02 \\
14.75 \\
15.35 \\
15.30 \\
15.82\end{array}$ & $\begin{array}{l}18.66 \\
17.80 \\
17.52 \\
18.42 \\
18.68 \\
17.73 \\
17.13\end{array}$ \\
\hline Overa11 & 599.7 & 595.2 & 603.5 & 493.89 & 450.80 & 509.80 & 17.26 & 10.94 & 18.68 \\
\hline
\end{tabular}

$a_{10} \mathrm{~h}$ of data unavailable in this time period. 
TABLE 4.6 Summary of Events for Test No. $3\left(650^{\circ} \mathrm{F}\right)$

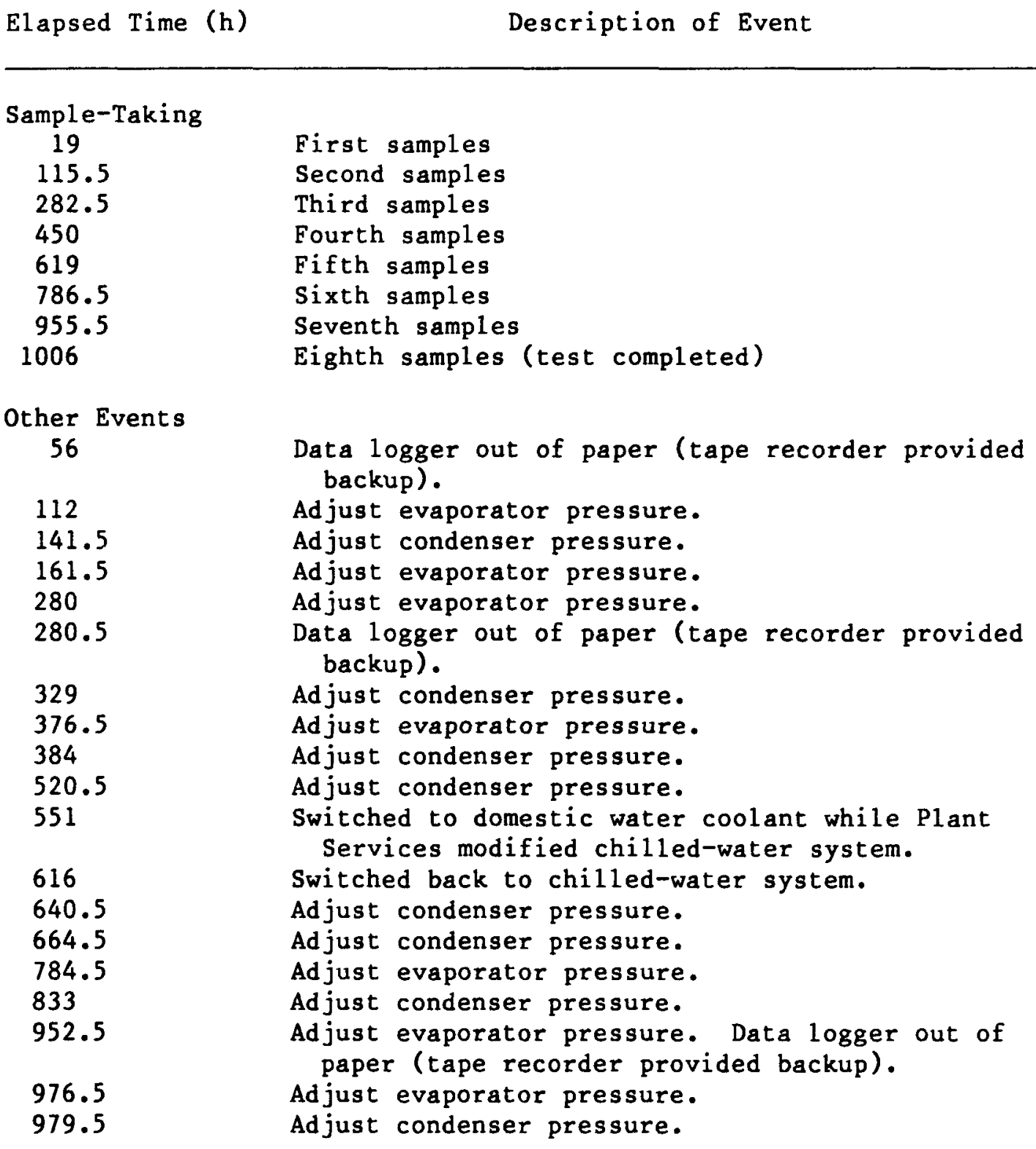

maximum of 517.3 psia. The average condenser pressure was 17.8 psia, with a minimum of 15.81 psia and a maximum of 19.49 psia. Although the original intent was to operate as close to $700^{\circ} \mathrm{F}$ as possible, the pressure limitation of 150 psi in the Dowtherm $\mathrm{A}$ section of the evaporator prohibited a closer approach to $700^{\circ} \mathrm{F}$.

Table 4.8 gives the elapsed times at which the samples were drawn and summarizes events that were recorded in the operations log. As the table shows, all of the events involve adjustment of temperature or pressure. Approximately the same number of adjustments were required for this test as for the test at $650^{\circ} \mathrm{F}$. 
TABLE 4.7 Summary of Temperatures and Pressures in Intervals between Samples for Test No. $3\left(650^{\circ} \mathrm{F}\right)$

\begin{tabular}{|c|c|c|c|c|c|c|c|c|c|}
\hline \multirow{2}{*}{$\begin{array}{l}\text { Interval } \\
\quad(\mathrm{h})\end{array}$} & \multicolumn{3}{|c|}{ Temp. $\left({ }^{\circ} \mathrm{F}\right)$} & \multicolumn{3}{|c|}{$\begin{array}{c}\text { Evaporator } \\
\text { Pressure (psia) }\end{array}$} & \multicolumn{3}{|c|}{$\begin{array}{c}\text { Condenser } \\
\text { Pressure (psia) }\end{array}$} \\
\hline & Avg. & Min. & Max. & Avg. & Min. & $\operatorname{Max}$ & Avg. & Min. & Max. \\
\hline $\begin{array}{c}0-19 \\
19-115^{\mathrm{a}} \\
115-282^{\mathrm{b}} \\
282-450 \\
450-619 \\
619-786 \\
786-955^{\mathrm{b}} \\
955-1006\end{array}$ & $\begin{array}{l}647.0 \\
649.3 \\
649.5 \\
649.7 \\
649.9 \\
649.9 \\
650.1 \\
649.7\end{array}$ & $\begin{array}{l}646.1 \\
648.0 \\
648.1 \\
648.5 \\
648.3 \\
648.5 \\
648.0 \\
635.8\end{array}$ & $\begin{array}{l}648.9 \\
650.5 \\
650.7 \\
651.3 \\
652.0 \\
650.9 \\
651.2 \\
650.7\end{array}$ & $\begin{array}{l}496.03 \\
502.35 \\
497.98 \\
498.13 \\
497.75 \\
498.46 \\
495.81 \\
495.58\end{array}$ & $\begin{array}{l}482.80 \\
487.20 \\
485.30 \\
488.30 \\
484.00 \\
486.10 \\
485.00 \\
485.50\end{array}$ & $\begin{array}{l}505.80 \\
515.80 \\
516.60 \\
506.80 \\
507.50 \\
512.60 \\
506.60 \\
505.70\end{array}$ & $\begin{array}{l}18.29 \\
17.15 \\
17.91 \\
18.03 \\
17.73 \\
17.90 \\
17.75 \\
18.20\end{array}$ & $\begin{array}{l}17.93 \\
15.90 \\
16.12 \\
15.79 \\
15.71 \\
16.02 \\
15.51 \\
14.73\end{array}$ & $\begin{array}{l}18.74 \\
17.75 \\
18.63 \\
18.58 \\
18.38 \\
18.70 \\
19.01 \\
19.01\end{array}$ \\
\hline Overa11 & 649.7 & 635.8 & 652.0 & 497.94 & 482.80 & 516.60 & 17.82 & 14.73 & 19.01 \\
\hline
\end{tabular}

${ }^{a}$ One hour of data unavailable in this time period.

$b_{0.5} h$ of data unavailable in this time period. 
TABLE 4.8 Summary of Events for Test No. $4\left(677^{\circ} \mathrm{F}\right)$

\begin{tabular}{|c|c|}
\hline Elapsed Time (h) & Description of Event \\
\hline $\begin{array}{l}\text { Sample-Taking } \\
117.5 \\
285 \\
452 \\
600 \\
789 \\
958 \\
1006\end{array}$ & $\begin{array}{l}\text { First samples } \\
\text { Second samples } \\
\text { Third samples } \\
\text { Fourth samples } \\
\text { Fifth samples } \\
\text { Sixth samples } \\
\text { Seventh samples (test completed) }\end{array}$ \\
\hline $\begin{array}{l}\text { Other Events } \\
20 \\
92 \\
140 \\
259 \\
427 \\
451 \\
477 \\
527.5 \\
596 \\
624.5 \\
672 \\
763.5 \\
817.5 \\
843\end{array}$ & $\begin{array}{l}\text { Ad just evaporator temperature. } \\
\text { Ad just evaporator temperature, evaporator pressure, } \\
\text { and condenser pressure. } \\
\text { Ad just evaporator and condenser pressures. } \\
\text { Ad just condenser pressure. } \\
\text { Ad just evaporator pressure. } \\
\text { Ad just condenser and evaporator pressures. } \\
\text { Ad just condenser and evaporator pressures. } \\
\text { Ad just evaporator pressure. } \\
\text { Ad just evaporator temperature. } \\
\text { Ad just condenser pressure. } \\
\text { Ad just condenser pressure. } \\
\text { Ad just evaporator and condenser pressures. } \\
\text { Ad just condenser pressure. } \\
\text { Ad just evaporator pressure. }\end{array}$ \\
\hline
\end{tabular}

Table 4.9 summarizes the temperatures and pressures in the intervals between taking of gaseous and liquid samples. All temperatures were within $5^{\circ} \mathrm{F}$ of the nominal $677^{\circ} \mathrm{F}$. Average evaporator pressures were within 10 psi of the nominal 500 psia, but several of the minima and maxima differed by more that 10 psi from the nominal value. All of the condenser pressures were within 3 psi of the nominal 18 psia. 
TABLE 4.9 Summary of Temperatures and Pressures in Intervals between Samples for Test No. $4\left(677^{\circ} \mathrm{F}\right)$

\begin{tabular}{|c|c|c|c|c|c|c|c|c|c|}
\hline \multirow{2}{*}{$\begin{array}{l}\text { Interval } \\
\text { (h) }\end{array}$} & \multicolumn{3}{|c|}{ Temp. $\left({ }^{\circ} \mathrm{F}\right)$} & \multicolumn{3}{|c|}{$\begin{array}{c}\text { Evaporator } \\
\text { Pressure (psia) } \\
\end{array}$} & \multicolumn{3}{|c|}{$\begin{array}{c}\text { Condenser } \\
\text { Pressure (psia) } \\
\end{array}$} \\
\hline & Avg. & Min. & Max. & Avg. & Min. & Max. & Avg. & Min. & $\operatorname{Max}$. \\
\hline $\begin{array}{r}0-117 \\
117-285 \\
285-452 \\
452-600 \\
600-789 \\
789-958 \\
958-1006\end{array}$ & $\begin{array}{l}676.6 \\
677.9 \\
678.1 \\
677.1 \\
677.6 \\
677.3 \\
677.8\end{array}$ & $\begin{array}{l}674.0 \\
676.3 \\
677.0 \\
675.9 \\
675.9 \\
675.8 \\
676.8\end{array}$ & $\begin{array}{l}678.7 \\
679.2 \\
679.2 \\
678.4 \\
679.1 \\
678.9 \\
679.1\end{array}$ & $\begin{array}{l}498.84 \\
501.03 \\
503.12 \\
500.07 \\
502.95 \\
496.54 \\
497.36\end{array}$ & $\begin{array}{l}481.00 \\
487.20 \\
494.90 \\
493.80 \\
490.40 \\
490.70 \\
491.00\end{array}$ & $\begin{array}{l}516.70 \\
517.30 \\
513.10 \\
510.70 \\
515.30 \\
509.40 \\
505.70\end{array}$ & $\begin{array}{l}17.76 \\
17.58 \\
17.96 \\
17.95 \\
17.98 \\
17.38 \\
17.51\end{array}$ & $\begin{array}{l}16.80 \\
16.35 \\
16.55 \\
17.30 \\
16.69 \\
16.10 \\
15.81\end{array}$ & $\begin{array}{l}18.54 \\
18.18 \\
18.76 \\
18.53 \\
19.49 \\
18.71 \\
17.93\end{array}$ \\
\hline Overall & 677.5 & 674.0 & 679.2 & 500.41 & 481.00 & 517.30 & 17.76 & 15.81 & 19.49 \\
\hline
\end{tabular}




\section{RESULTS}

In this section, impurities and degradation products are identified and quantified for each sample. Chemical reactions leading to the major degradation products are identified. Degradation rates for each test are computed, and a method of predicting degradation, given temperatures and pressures in an ORC system, is developed for situations where one chemical reaction is dominant. A means of extending the prediction method to situations where two or more chemical reactions are important is shown.

\subsection{IDENTIFICATION OF LIQUID-PHASE IMPURITIES AND DEGRADATION PRODUCTS}

Impurities and degradation products in the liquid samples are identified by gas chromatography/mass spectroscopy (GC/MS), which produces a unique spectrum of molecular fragments for each component. Components are identified by comparing their spectra with catalogued spectra of known compounds. Spectra of components are shown in App. B. The retention time of the compound in the gas chromatograph is then correlated with the identification. When a sample is analyzed on the gas chromatograph with a flame ionization detector (FID), the chromatograms and reports shown in Apps. C and $D$, respectively, are produced.

The most important initial impurities in the toluene, in descending order of importance, are ethylcyclohexane, C2-cyclohexane isomers, xylene, ethylbenzene, benzene, dimethylcyclopentane isomers, C8-alkane isomers, and ethylmethylcyclopentane isomers. For the $635^{\circ} \mathrm{F}$ run, a small quantity of Dowtherm A (consisting of biphenyl and diphenyl ether) is seen as a system contaminant. After operating the loop at temperature, the following degradation products are seen (in descending order of importance): bibenzyl, C2-biphenyl isomers, C1-diphenylmethane isomers, C1-biphenyl, diphenylmethane, C1-fluorene, C3-biphenyl, and benzaldehyde. Benzaldehyde, a partial oxidation product of toluene, could derive from four sources: (1) air remaining dissolved in the initial charge of toluene after the dissolved-gas-removal procedure; (2) air remaining in the loop after evacuation but before the initial charge of toluene was loaded, (3) oxygen-bearing impurities, such as ethers, that were present in the initial charge of toluene; and (4) in-leakage of air during the experimental runs. Whatever the source, oxygen reacts immediately with toluene to form benzaldehyde, as shown in Eq. 5.1.

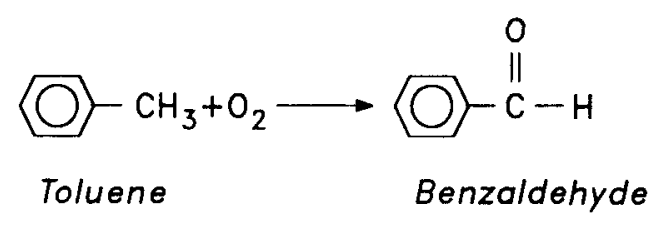


Components seen in the gaseous samples included hydrogen, methane, carbon monoxide and nitrogen (which cannot be distinguished from one another, because both have a molecular weight of 28), carbon dioxide, argon and helium (which are used for purging the loop and for leak detection), toluene vapor, and other hydrocarbons. The most significant of these components are hydrogen and methane.

\subsubsection{Impurities}

Although the toluene purchased for these studies is the purest commercially available (Aldrich Gold label), two major classes of chemical impurities are still present at parts-per-million levels: saturated cycloalkanes and aromatics. These impurities elute immediately before or after the toluene.

\subsubsection{Cycloalkanes}

Substituted cycloalkanes are the predominant impurity in toluene. They are relatively stable compared with the toluene itself, and their concentrations vary by only a small amount throughout this study.

By itself, GC/MS is not capable of identifying different isomers of each component. Hence, it is possible to identify an impurity as a C8-cycloalkane, but it is not always possible to positively determine whether the impurity is a C2-cyclohexane or a C3-cyclopentane. Even in cases where it is possible to differentiate the cyclohexanes from cyclopentanes, it is possible to distinguish the different alkylcyclohexane or cyclopentane isomers from each other only occasionally. An example of a typical mass spectrum for a C8-cycloalkane is shown in Fig. 5.1. As can be seen, the geometrical isomers have virtually identical mass spectra. Because these impurities play an insignificant role in degradation and because the identity of each individual isomer is not essential for this project, in most cases we limited the identification to the general form (i.e., C8-cycloalkane). The capability to show that the concentrations of individual cycloalkanes are constant throughout the temperature ranges studied is more important than specifying the identity of each impurity in terms of exact geometrical isomers. For a few of the components, where the identification is not ambiguous (e.g., ethylcyclohexane), we identify the component by its full name.

\subsubsection{Aromaties}

The aromatic impurities present in toluene are benzene, ethylbenzene, and the three xylenes. The benzene is readily discernible by GC/MS, and the ethylbenzene and xylenes (which have identical mass spectra) are identified by the use of standards. The aromatic components do participate in degradation reactions and form identifiable degradation products of their own. The concentrations of benzene, ethylbenzene, and xylene are noted in each of the degraded samples analyzed. 


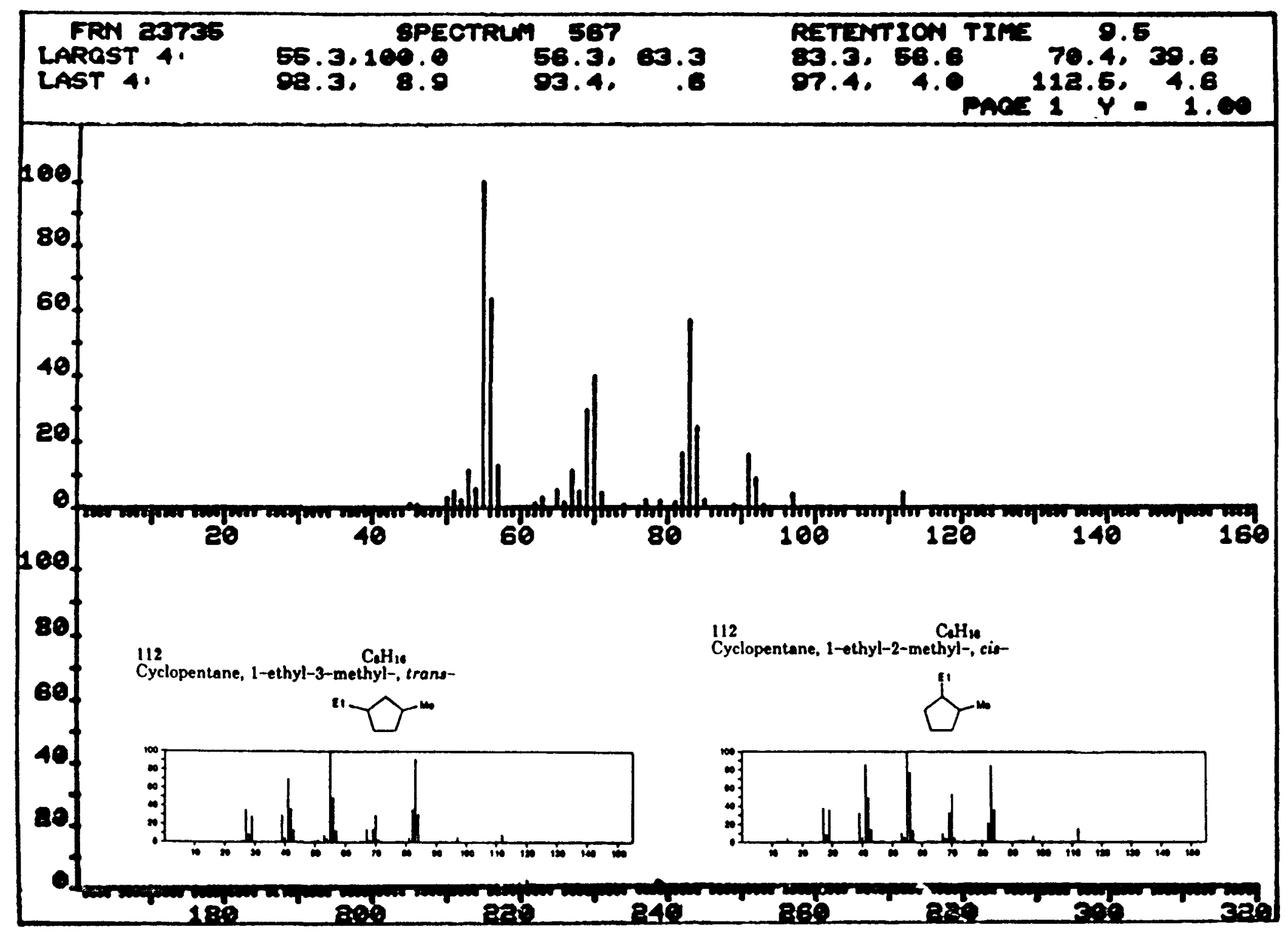

FIGURE 5.1 Mass Spectrum of C8-Cycloalkane Compared with Library Spectra 


\subsubsection{Degradation Products}

Three major types and two minor types of degradation products are identified by GC/MS. The most important are dimers, which consist of bibenzyl, C2-biphenyls, and C1-diphenylmethanes. Alkylbenzenes and C1-fluorenes are present in low concentration.

Bibenzyl, which is easily identified by its unique mass spectrum, is the predominant dimer formed at the temperatures studied. It is formed from a benzyl radical $\left(\mathrm{C}_{6} \mathrm{H}_{5} \mathrm{CH}_{2}{ }^{\circ}\right)$ reacting with another benzyl radical.

C2-biphenyls and C1-diphenylmethane are also formed. In the case of C2-biphenyls, the radical is on a ring position and reacts with another ring radical. C1-diphenylmethane is formed by a benzyl radical reacting with a ring radical.

Two commercially available dimethylbiphenyls (3,3-dimethylbiphenyl and 4,4dimethylbiphenyl) are used as calibration standards. Identifications in our samples are based upon the retention times of these two isomers and the four mass spectra available from the literature. In each case, the molecular ion at $\mathrm{M} / \mathrm{e}=182$ is the base peak, and the M-13 and M-15 fragments are less than half the height of the molecular ion. All components for which this is the case are identified as C2-biphenyls. Only the 3,3 and 4,4 isomers are specifically identified, because their identification is based upon their retention time as established by the standard and their mass spectra. All others with the same mass spectra are identified only as C2-biphenyls. An example of a typical C2-biphenyl and its match with a library of spectra is shown in Fig. 5.2.

Isomers of C1-diphenylmethane are not commercially available, nor are they in mass spectra libraries. From their structure, we determined that their $\mathbf{M - 1 5}$ fragment is more stable than the molecular ion. This stability is due to the extension of aromaticity to the methane carbon (resonance hybrid), made possible by the loss of the methyl group. We anticipated that these components would have an M-15 fragment of greater intensity than the molecular ion. All components having a molecular fragment of $M / e=167$ of greater intensity than the molecular ion at $M / e=182$ are identified as C1-diphenylmethanes.

In addition to the above, small quantities of biphenyl, C1-biphenyl and C3-biphenyl, were identified. C1-biphenyls have a molecular ion at $\mathrm{M} / \mathrm{e}=168$, and C3-biphenyls have a molecular ion at $\mathrm{M} / \mathrm{e}=196$. No attempt was made to identify which isomers of each product are formed. The C1-biphenyl is the product of a benzyl radical and a phenyl radical, whereas the C3-biphenyl is the product of a benzyl radical and a xylenyl radical. These products demonstrate the reactivity of the toluene impurities, benzene and xylene.

As a group, the substituted benzenes are in low concentration. Because the mass spectra of geometrical isomers are identical, each geometrical isomer could not be specified; hence, identification is limited to $\mathrm{C} 3$-benzene. The identification of the length of the side chain is routine because of the increment of 14 mass units for each 


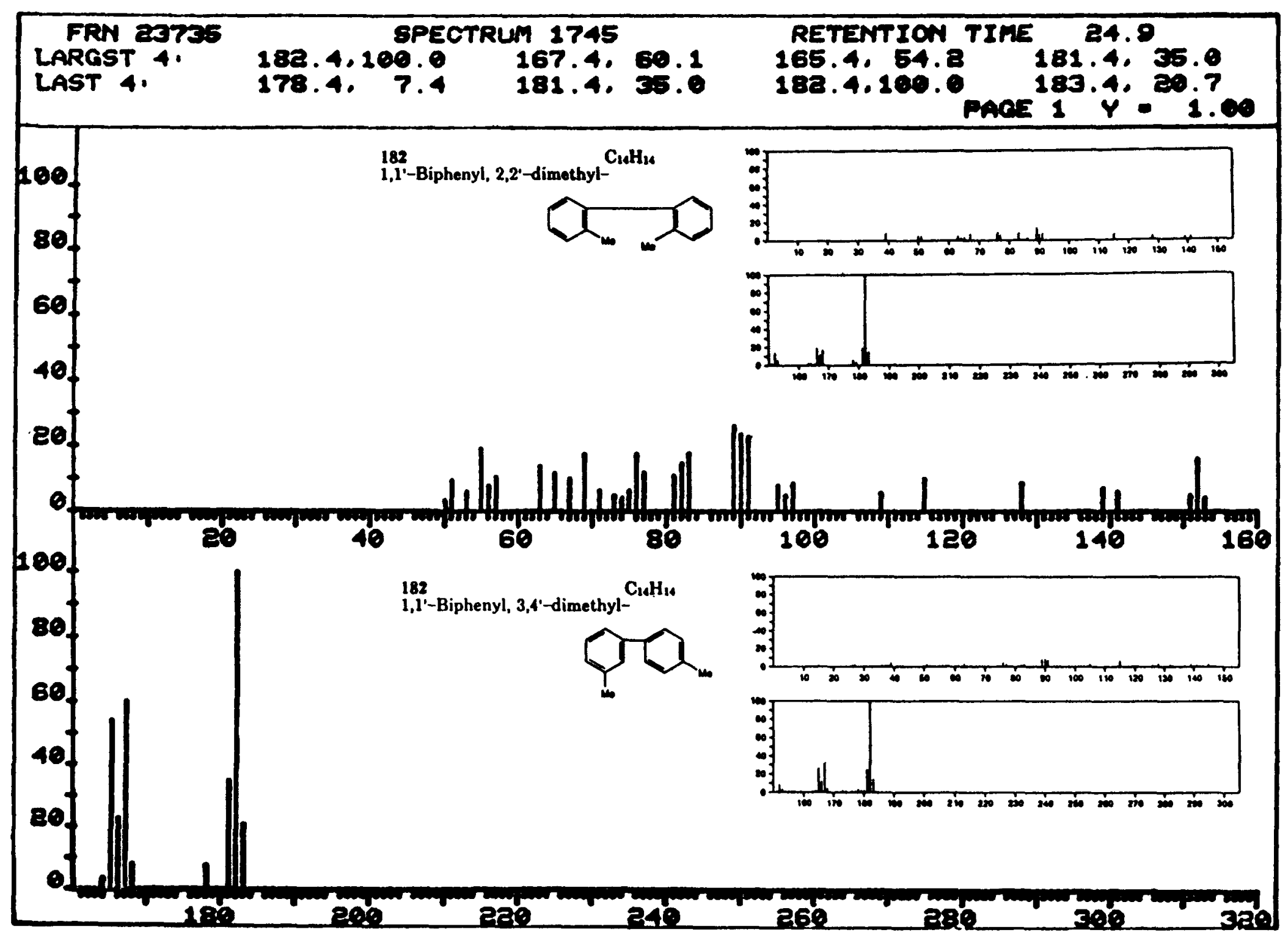

FIGURE 5.2 Mass Spectrum of C2-Biphenyl Compared with Library Spectra 
additional $-\mathrm{CH}_{2}-$. The following list indicates the method used to identify each of these components:

\begin{tabular}{lc} 
Name & Molecular Ion \\
\cline { 2 - 2 } C3-benzene & 120 \\
C4-benzene & 134 \\
C5-benzene & 148
\end{tabular}

C1-fluorenes were unexpected as degradation products. They are formed in low concentration by a benzyl radical reacting with a toluene radical. The formation of this type of compound indicates that at higher temperature other aromatics, such as phenanthrene and anthracene, would form. C1-fluorenes have molecular ions at $M / e=180$, and identifications are based upon the presence of this ion.

A complete GC/MS run, including the total ion chromatogram and mass spectra for each component, is presented in App. B.

\subsection{MECHANISMS OF DEGRADATION}

Degradation appears to take place in three stages: (1) formation of radicals, (2) reaction of radicals with themselves and with toluene, and (3) complex reactions with degradation products, impurities, and their radicals. Formation of the benzyl radical as shown in Eg. 5.2 is the most likely first step, because such a reaction has a lower activation energy than other radical-formation reactions. The fact that bibenzyl is the most important degradation product, rather than C2-biphenyls or C1-diphenylmethane, supports this hypothesis. Removal of the methyl group (Eq. 5.3) or removal of a ring hydrogen (Eq. 5.4) are also possible, but these reactions have higher activation energies than that expressed in Eq. 5.2. At lower temperatures, Eq. 5.2 is expected to dominate, but at higher temperatures, Eq. 5.4 could dominate (because it has five possible activation sites, compared with only three for Eq. 5.2). Thus, at sufficiently high temperatures the probability of the reaction expressed in Eq. 5.4 occurring would be greater than the probability of that in Eq. 5.2 occurring. A fourth fundamental reaction, that of cleaving the ring to form alkenes, would have a higher activation energy than those of the reactions in either Eq. 5.3 or Eq. 5.4. Evidence of ring cleavage is found in the gas sample analysis.

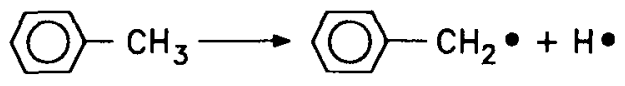

Toluene

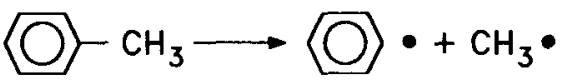

Toluene 


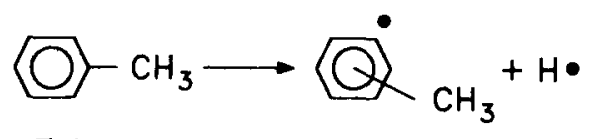

Toluene

The most likely reaction is that of a benzyl radical reacting with the methyl group of a toluene molecule to form bibenzyl (Eq. 5.5). For each bibenzyl molecule formed in this way, two hydrogen atoms are liberated, which can form a hydrogen molecule (Eq. 5.6). It is also possible for the benzyl radical to attack the ring of a toluene molecule to form C1-diphenylmethane (Eq. 5.7). Not much C1-diphenylmethane is formed by this mechanism, because more energy is required to remove a ring hydrogen from toluene than to remove a methyl-group hydrogen.

$$
\begin{aligned}
& \text { (O) }-\mathrm{CH}_{2} \bullet+\mathrm{O}-\mathrm{CH}_{3} \longrightarrow \mathrm{O}-\mathrm{CH}_{2}-\mathrm{CH}_{2}-\mathrm{O}+\mathrm{H} \bullet \\
& \text { Bibenzyl } \\
& 2 \mathrm{H} \bullet \longrightarrow \mathrm{H}_{2} \\
& \text { Hydrogen } \\
& \text { O }-\mathrm{CH}_{2} \cdot+\mathrm{O}-\mathrm{CH}_{3} \longrightarrow \mathrm{O}-\mathrm{CH}_{2}-\mathrm{O} \mathrm{CH}^{3}+\mathrm{H} \cdot \\
& \text { C1-Diphenylmethane }
\end{aligned}
$$

The phenyl radical and the methyl radical formed from the reaction in Eq. 5.3 can react in several ways. First, they can combine with hydrogen to form benzene (Eq. 5.8) or methane (Eq. 5.9). Benzene is a large impurity in the initial charge of toluene, so it is difficult to measure the change directly, but the formation of methane at the higher temperatures indicates that there is sufficient energy for these reactions to occur. Second, the methyl radical can react with the toluene molecule to form xylene, another large impurity (Eg. 5.10). Diphenyl methane and C1-biphenyl are seen at the higher temperatures and are evidence that the reactions expressed in Egs. 5.11 and 5.12 occur.

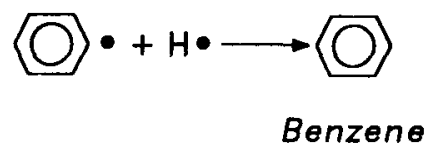




$$
\begin{aligned}
& \mathrm{CH}_{3} \bullet+\mathrm{H} \bullet \longrightarrow \mathrm{CH}_{4} \\
& \text { Methane } \\
& \text { (O) }-\mathrm{CH}_{3}+\mathrm{CH}_{3} \bullet \longrightarrow \mathrm{CH}_{3}-\mathrm{O} \mathrm{CH}^{3}+\mathrm{H} \bullet \\
& \text { Toluene Xylene } \\
& \left\langle\mathrm{O} \cdot+\mathrm{O}-\mathrm{CH}_{3} \longrightarrow \mathrm{O}-\mathrm{CH}_{2}-\mathrm{O}+\mathrm{H} \bullet\right. \\
& \text { Toluene Diphenylmethane } \\
& \left\langle\mathrm{O} \cdot+\mathrm{O}-\mathrm{CH}_{3} \longrightarrow \mathrm{O}-\mathrm{O} \mathrm{CH}^{\mathrm{CH}_{3}+\mathrm{H} \bullet}\right. \\
& \text { Toluene C1-biphenyl }
\end{aligned}
$$

The reaction expressed in Eq. 5.4 offers five times as many sites for radical formation as that expressed in Eq. 5.3, so the statistical probability for reaction 5.4 could be greater than that for reaction 5.3. Compounds that can be formed from the activated ring are C2-biphenyl (Eq. 5.13), C1-diphenylmethane (Eq. 5.14), and C1-fluorene (Eq. 5.15), all of which are seen at the higher temperatures. Formation of C1-diphenylmethane by reaction 5.14 appears to be more likely than by reaction 5.7. Equation 5.16 shows how xylene, a large impurity in the initial charge of toluene, can be formed.

$$
\begin{aligned}
& Q{ }_{\mathrm{CH}_{3}}+\mathrm{O}-\mathrm{CH}_{3} \stackrel{\mathrm{CH}_{3}}{\longrightarrow} \mathrm{O}-\mathrm{O}^{\mathrm{CH}_{3}}+\mathrm{H} \cdot \\
& \text { Toluene C2-biphenyl }
\end{aligned}
$$

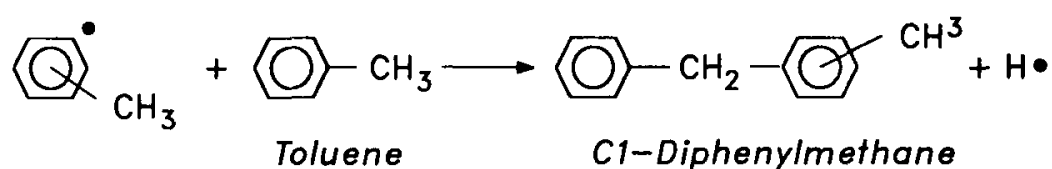




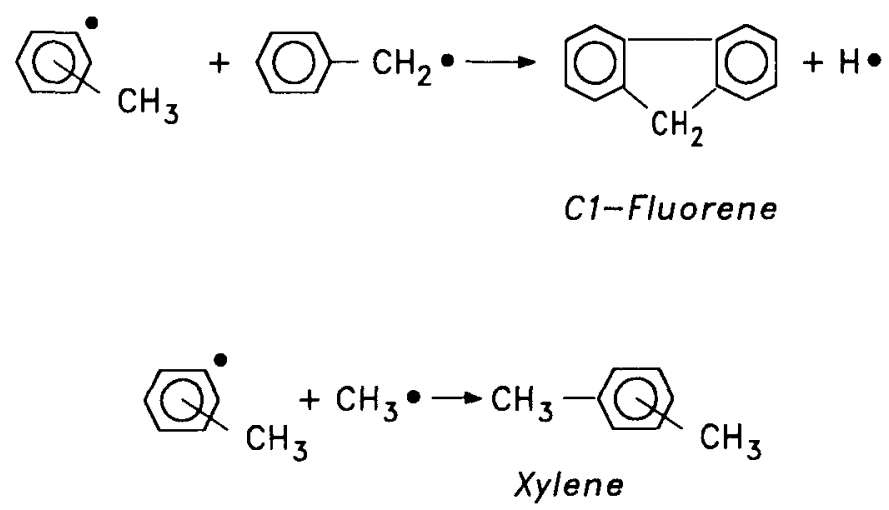

Reactions of degradation products with toluene, initial impurities, and each other would be complex. Such reactions would lead to a large variety of high-molecular-weight compounds, as can be seen in the chromatograms for the higher-temperature runs. Such compounds are less volatile than toluene and would have a tendency to foul the evaporator; however, measurement of heat-transfer coefficients as a function of time was beyond the scope of the present work.

\subsection{LIQUID-PHASE ANALYSIS}

In this section, quantitative results of liquid-phase analysis are summarized. The various impurities present in the toluene before testing, as well as benzaldehyde, are shown to create no problems that would invalidate a test. Total degradation rates for each test temperature are computed, and the implications of different degradation products being formed by different mechanisms are discussed.

The gas chromatography reports shown in App. D are summarized in Tables 5.1-5.4. These tables show quantities of the most important impurities and degradation products in parts per million by weight for each sample that was analyzed, together with the totals of each. The most important impurities are benzene, ethylcyclohexane, and xylene. Test run no. $1\left(635^{\circ} \mathrm{F}\right)$ shows a small quantity of diphenyl ether due to a leak of Dowtherm $A$ into the vacuum system. None of these impurities is present in a large enough quantity to invalidate the tests.

The major degradation products are bibenzyl, C1-biphenyl, C2-biphenyl, C1-fluorene, and diphenylmethane. Benzaldehyde is an indicator of air leakage into the loop. Benzaldehyde concentrations are plotted in Fig. 5.3. All but three points show benzaldehyde concentrations of less than $20 \mathrm{ppm}$. High values at 168 and $504 \mathrm{~h}$ for test run no. $1\left(635^{\circ} \mathrm{F}\right)$ indicate sudden brief increases in the air leakage rate (due to low condenser pressure in the first case and $21 \mathrm{~h}$ of downtime in the second). All other points show a slow but steady increase in benzaldehyde concentrations, the highest rate being for test run no. 1. Between test runs nos. 1 and 2 and test runs nos. 2 and 3 , several packed stem valves in the low-pressure areas of the loop were replaced with bellows-seal valves. Figure 5.3 shows that the later tests have a lower rate of benzaldehyde increase than the earlier tests have, but in no case is the quantity of benzaldehyde sufficient to indicate a catastrophic air leak. 
TABLE 5.1 Degradation of Selected Components at $635^{\circ} \mathrm{F}$ (ppm by weight)

\begin{tabular}{|c|c|c|c|c|c|c|c|}
\hline Component & $0 h^{a}$ & $45 \mathrm{~h}$ & $168 \mathrm{~h}$ & $338 \mathrm{~h}$ & $504 \mathrm{~h}$ & $649 \mathrm{~h}$ & $840 h$ \\
\hline $\begin{array}{l}\text { Benzene } \\
\text { Ethylcyclohexane } \\
\text { Xylene }\end{array}$ & $\begin{array}{l}114.2 \\
331 \cdot 5 \\
263.9\end{array}$ & $\begin{array}{l}112.4 \\
326.4 \\
253 \cdot 1\end{array}$ & $\begin{array}{r}73.2 \\
327.0 \\
254.8\end{array}$ & $\begin{array}{r}63.4 \\
332.8 \\
267.1\end{array}$ & $\begin{array}{r}79.3 \\
321.6 \\
248.4\end{array}$ & $\begin{array}{r}67.6 \\
325.4 \\
252.9\end{array}$ & $\begin{array}{r}65.6 \\
328.5 \\
256.5\end{array}$ \\
\hline $\begin{array}{l}\text { Dipheny1 ether } \\
\text { Benzaldehyde } \\
\text { Bibenzy1 } \\
\text { C2-biphenyls } \\
\text { C1-fluorene }\end{array}$ & $\begin{array}{l}0 \\
0 \\
0 \\
0 \\
0\end{array}$ & $\begin{array}{l}23.5 \\
32.4 \\
9.8 \\
0 \\
0\end{array}$ & $\begin{array}{c}4.1 \\
22.4 \\
16.4 \\
0 \\
0\end{array}$ & $\begin{array}{l}\mathrm{BT}^{\mathrm{b}} \\
12.6 \\
26.5 \\
0 \\
8.1\end{array}$ & $\begin{array}{l}3.9 \\
44.0 \\
32.7 \\
0 \\
8.3\end{array}$ & $\begin{array}{l}4.0 \\
18.6 \\
45.1 \\
0 \\
5.9\end{array}$ & $\begin{array}{l}3.5 \\
17.3 \\
48.9 \\
0 \\
8.2\end{array}$ \\
\hline $\begin{array}{l}\text { Total impurities } \\
\text { Total degradation } \\
\text { products }\end{array}$ & $\begin{array}{c}1493.9 \\
0\end{array}$ & $\begin{array}{r}1502.1 \\
48.3\end{array}$ & $\begin{array}{r}1465.5 \\
40.8\end{array}$ & $\begin{array}{r}1565.6 \\
47.1\end{array}$ & $\begin{array}{r}1494.8 \\
85.0\end{array}$ & $\begin{array}{r}1487.7 \\
69.5\end{array}$ & $\begin{array}{r}1445.4 \\
76.3\end{array}$ \\
\hline
\end{tabular}

${ }^{a_{B}}$ fore loading the loop.

${ }^{b}$ Below threshold. 
TABLE 5.2 Degradation of Selected Components at $600^{\circ} \mathrm{F}$ (ppm by weight)

\begin{tabular}{|c|c|c|c|c|c|c|c|c|}
\hline Component & Flush & $23 \mathrm{~h}$ & $266 \mathrm{~h}$ & $455 \mathrm{~h}$ & $623 \mathrm{~h}$ & $766 \mathrm{~h}$ & $938 \mathrm{~h}$ & $1006 \mathrm{~h}$ \\
\hline Benzene & 127 & 109 & 107 & $100^{a}$ & 91 & 94 & 93 & 93 \\
\hline Ethylcyclohexane & 235 & 236 & 242 & 244 & 247 & 245 & 245 & 245 \\
\hline Xylene & 138 & 145 & 160 & 164 & 171 & 168 & 167 & 168 \\
\hline Benzal dehyde & 0 & 10.2 & 7.2 & 9.3 & 11.8 & 12.5 & 23.3 & 22.0 \\
\hline $\begin{array}{l}\text { Dowtherm and } \\
\text { cl-bipheny } 1\end{array}$ & 5.9 & 7.2 & 7.2 & 7.7 & 7.8 & 8.3 & 8.6 & 8.2 \\
\hline Bibenzyl & 0 & 7.1 & 21.6 & 32.8 & 40.2 & 50.4 & 66.3 & 63.6 \\
\hline C2-biphenyl & 0 & 0 & 0 & 0 & 2.4 & 0 & & 3.8 \\
\hline Cl-fluorene & 0 & 0 & 0 & 4.4 & 5.1 & 6.0 & 5.7 & 7.5 \\
\hline $\begin{array}{l}\text { Total impurities } \\
\text { Total degradation } \\
\text { products }\end{array}$ & $\begin{array}{r}1177 \\
5.9^{b}\end{array}$ & $\begin{array}{r}1177 \\
24.5\end{array}$ & $\begin{array}{r}1139 \\
36.0\end{array}$ & $\begin{array}{r}1164 \\
54.2\end{array}$ & $\begin{array}{r}1164 \\
70.2\end{array}$ & $\begin{array}{r}1176 \\
80.0\end{array}$ & $\begin{array}{l}1269 \\
103.9\end{array}$ & $\begin{array}{l}1269 \\
105.4\end{array}$ \\
\hline
\end{tabular}

${ }^{a}$ Value calculated from PE 7500 .

${ }^{b}$ Dowtherm contaminant . 
TABLE 5.3 Degradation of Selected Components at $650^{\circ} \mathrm{F}$ (ppm by weight)

\begin{tabular}{|c|c|c|c|c|c|c|c|c|c|}
\hline Component & Flush & $19 \mathrm{~h}$ & $115 \mathrm{~h}$ & $282 \mathrm{~h}$ & $450 \mathrm{~h}$ & $619 \mathrm{~h}$ & $786 \mathrm{~h}$ & $955 \mathrm{~h}$ & $1006 \mathrm{~h}$ \\
\hline $\begin{array}{l}\text { Benzene } \\
\text { Ethylcyclohexane } \\
\text { Xylene }\end{array}$ & $\begin{array}{l}97.3 \\
201.6 \\
269.3\end{array}$ & $\begin{array}{l}108.5 \\
196.3 \\
253.2\end{array}$ & $\begin{array}{l}103.3 \\
194.4 \\
247.6\end{array}$ & $\begin{array}{r}97.7 \\
198.3 \\
263.1\end{array}$ & $\begin{array}{r}96.4 \\
195.7 \\
259.2\end{array}$ & $\begin{array}{r}88.9 \\
187.0 \\
243.8\end{array}$ & $\begin{array}{r}89.4 \\
195.7 \\
258.2\end{array}$ & $\begin{array}{l}104.0 \\
194.3 \\
253.5\end{array}$ & $\begin{array}{r}91.5 \\
190.9 \\
257.2\end{array}$ \\
\hline $\begin{array}{l}\text { Benzal dehyde } \\
\text { 1-biphenyl } \\
\text { Bibenzyl } \\
\text { C2-biphenyls } \\
\text { C1-fluorene }\end{array}$ & $\begin{array}{l}0 \\
0 \\
0 \\
0 \\
0\end{array}$ & $\begin{array}{l}2.0 \\
0 \\
7.6 \\
0 \\
0\end{array}$ & $\begin{array}{l}2.1 \\
0 \\
19.0 \\
0 \\
0\end{array}$ & $\begin{array}{l}4.9 \\
0 \\
63.2 \\
0 \\
0\end{array}$ & $\begin{array}{r}5.4 \\
4.0 \\
85.5 \\
10.0 \\
4.9\end{array}$ & $\begin{array}{r}5.6 \\
4.2 \\
89.3 \\
11.0 \\
11.6\end{array}$ & $\begin{array}{r}7.4 \\
6.0 \\
128.5 \\
16.6 \\
16.9\end{array}$ & $\begin{array}{r}8.3 \\
7.6 \\
153.2 \\
19.6 \\
19.9\end{array}$ & $\begin{array}{r}12.0 \\
7.7 \\
165.5 \\
25.4 \\
4.9\end{array}$ \\
\hline $\begin{array}{l}\text { Total impurities } \\
\text { Total degradation } \\
\text { products }\end{array}$ & $\begin{array}{r}740 \\
0.0\end{array}$ & $\begin{array}{r}1189 \\
9.6\end{array}$ & $\begin{array}{r}1170 \\
21.1\end{array}$ & $\begin{array}{c}1267 \\
71.1\end{array}$ & $\begin{array}{c}1279 \\
115.9\end{array}$ & $\begin{array}{l}1231 \\
126.0\end{array}$ & $\begin{array}{c}1355 \\
194.6\end{array}$ & $\begin{array}{c}1402 \\
231.9\end{array}$ & $\begin{array}{l}1272 \\
228.0\end{array}$ \\
\hline
\end{tabular}


TABLE 5.4 Degradation of Selected Components at $677^{\circ} \mathrm{F}$ (ppm by weight)

\begin{tabular}{|c|c|c|c|c|c|c|c|}
\hline Component & $0 \mathrm{~h}$ & $117 \mathrm{~h}$ & $285 \mathrm{~h}$ & $600 \mathrm{~h}$ & $789 \mathrm{~h}$ & $958 \mathrm{~h}$ & $1006 \mathrm{~h}$ \\
\hline $\begin{array}{l}\text { Benzene } \\
\text { Ethylcyclohexane } \\
\text { Xylene }\end{array}$ & $\begin{array}{r}83.9 \\
472.1 \\
89.5\end{array}$ & $\begin{array}{r}82.0 \\
472.6 \\
92.0\end{array}$ & $\begin{array}{r}82.5 \\
469.6 \\
91.5\end{array}$ & $\begin{array}{r}75.9 \\
472.2 \\
90.3\end{array}$ & $\begin{array}{r}73.8 \\
468.0 \\
90.7\end{array}$ & $\begin{array}{r}76.9 \\
466.1 \\
90.8\end{array}$ & $\begin{array}{r}72.4 \\
468.2 \\
93.3\end{array}$ \\
\hline $\begin{array}{l}\text { Benzal dehyde } \\
\text { Di phenyl methane } \\
\text { Bi benzyl } \\
\text { C2-bi phenyls } \\
\text { C1-fluorene }\end{array}$ & $\begin{array}{l}0 \\
0 \\
0 \\
0 \\
0\end{array}$ & $\begin{array}{l}2.1 \\
0 \\
37.1 \\
2.4 \\
0\end{array}$ & $\begin{array}{r}2.6 \\
3.0 \\
60.6 \\
8.6 \\
3.8\end{array}$ & $\begin{array}{r}4.1 \\
6.5 \\
120.7 \\
18.4 \\
4.7\end{array}$ & $\begin{array}{r}4.6 \\
9.1 \\
163.2 \\
27.3 \\
8.5\end{array}$ & $\begin{array}{r}5.1 \\
12.0 \\
202.8 \\
34.8 \\
10.6\end{array}$ & $\begin{array}{r}10.6 \\
9.6 \\
178.8 \\
29.2 \\
-\end{array}$ \\
\hline $\begin{array}{l}\text { Total impurities } \\
\text { Tota1 degradation } \\
\text { products }\end{array}$ & $\begin{array}{c}1452.5 \\
0\end{array}$ & $\begin{array}{r}1449.0 \\
41.6\end{array}$ & $\begin{array}{r}1459.7 \\
78.6\end{array}$ & $\begin{array}{r}1480.0 \\
161.3\end{array}$ & $\begin{array}{r}1647.5 \\
237.7\end{array}$ & $\begin{array}{r}1696.0 \\
302.9\end{array}$ & $\begin{array}{r}1587.0 \\
246.0\end{array}$ \\
\hline
\end{tabular}




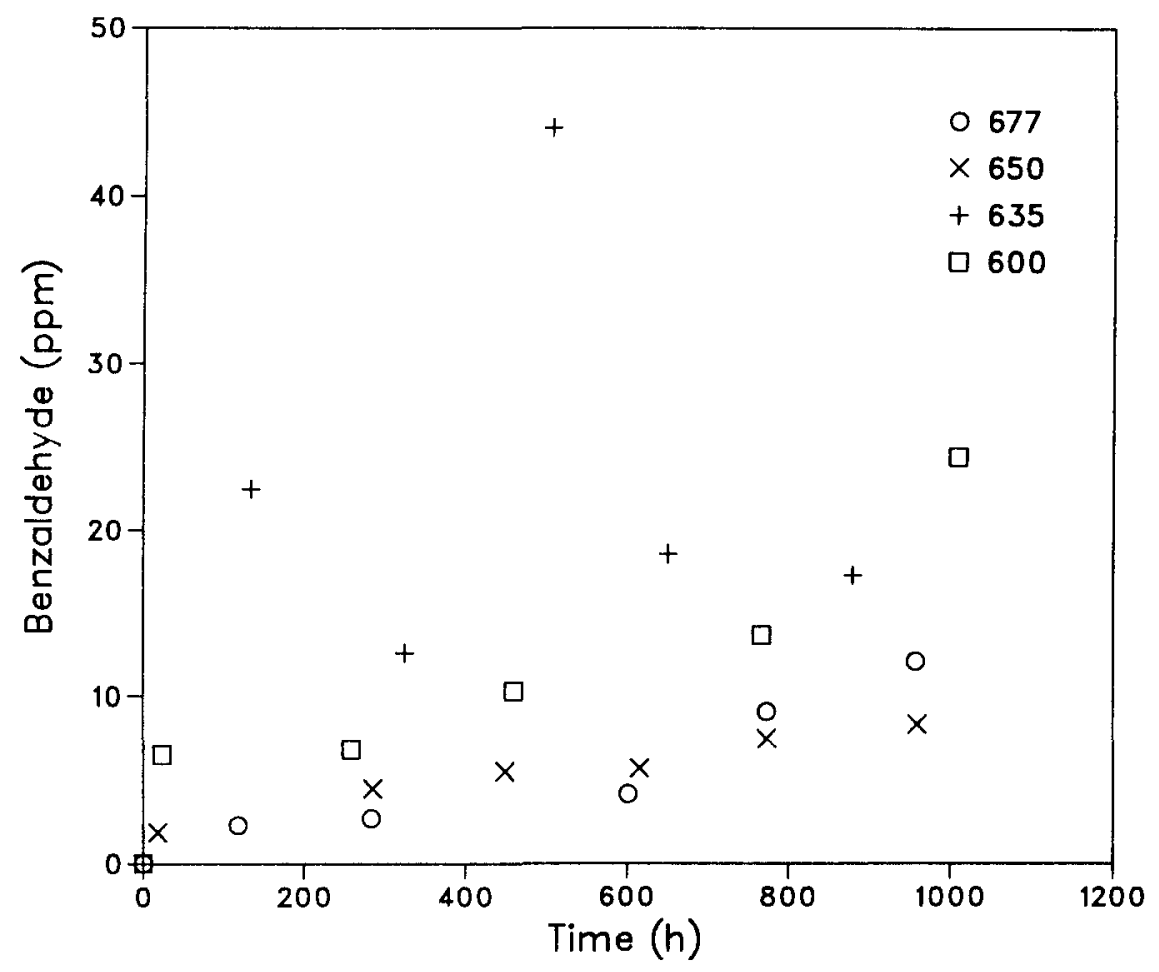

FIGURE 5.3 Benzaldehyde Concentrations

Total degradation is plotted in Fig. 5.4 as a function of time and temperature. As one would expect, the figure shows a steady increase of degradation products with time, and the rate of increase increases with temperature. Linear least-square fits of the data for each test temperature are also shown in the figure. The slope of each line is the total degradation rate for that particular temperature. The total degradation rates are $0.108,0.0726,0.248$, and $0.306 \mathrm{ppm} / \mathrm{h}$ for test temperatures of $600,635,650$, and $677^{\circ} \mathrm{F}$, respectively. The total degradation is the sum of individual products, each of which can have different formation mechanisms and formation rates.

The major degradation product is bibenzyl, which is formed through the processes indicated in Eqs. 5.2 and 5.5. Bibenzyl concentration as a function of time and test temperature is plotted in Fig. 5.5. The figure shows a steady increase in bibenzyl concentration with time, and the rate of increase increases with test temperature.

The second most important degradation product is C2-biphenyl, which is formed through the processes indicated in Eqs. 5.4 and 5.13. C2-biphenyl concentration as a function of time and test temperature are shown in Fig. 5.6. As with the bibenzyl concentration, the concentration of C2-biphenyl increases with time, and the rate of increase increases with temperature. At the lower test temperatures, 600 and $635^{\circ} \mathrm{F}$, very little C2-biphenyl was found.

Two different mechanisms are required for formation of bibenzyl and C2-biphenyl. To form bibenzyl the methyl-group carbon must be activated, but to form C2-biphenyl a ring carbon must be activated. Since the concentration of bibenzyl greatly 


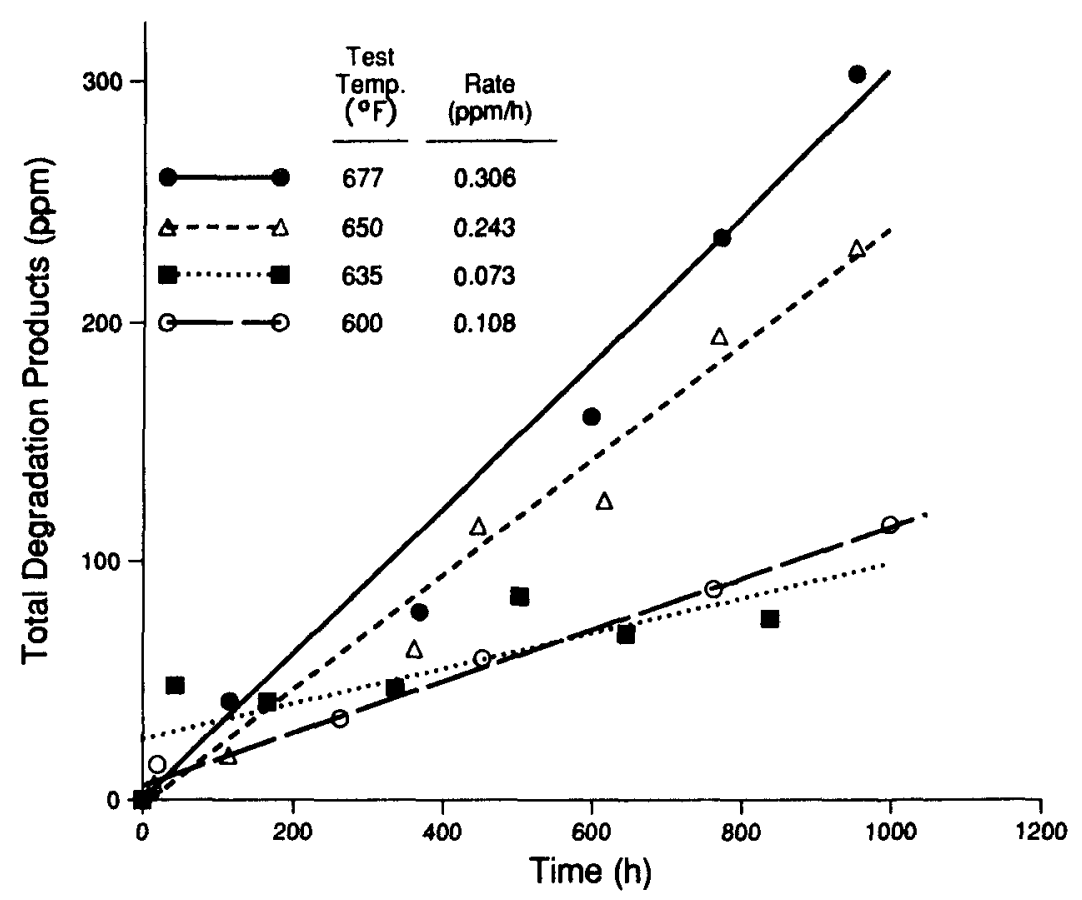

FIGURE 5.4 Total Degradation, with a Least-Square Fit of Data for Each Test

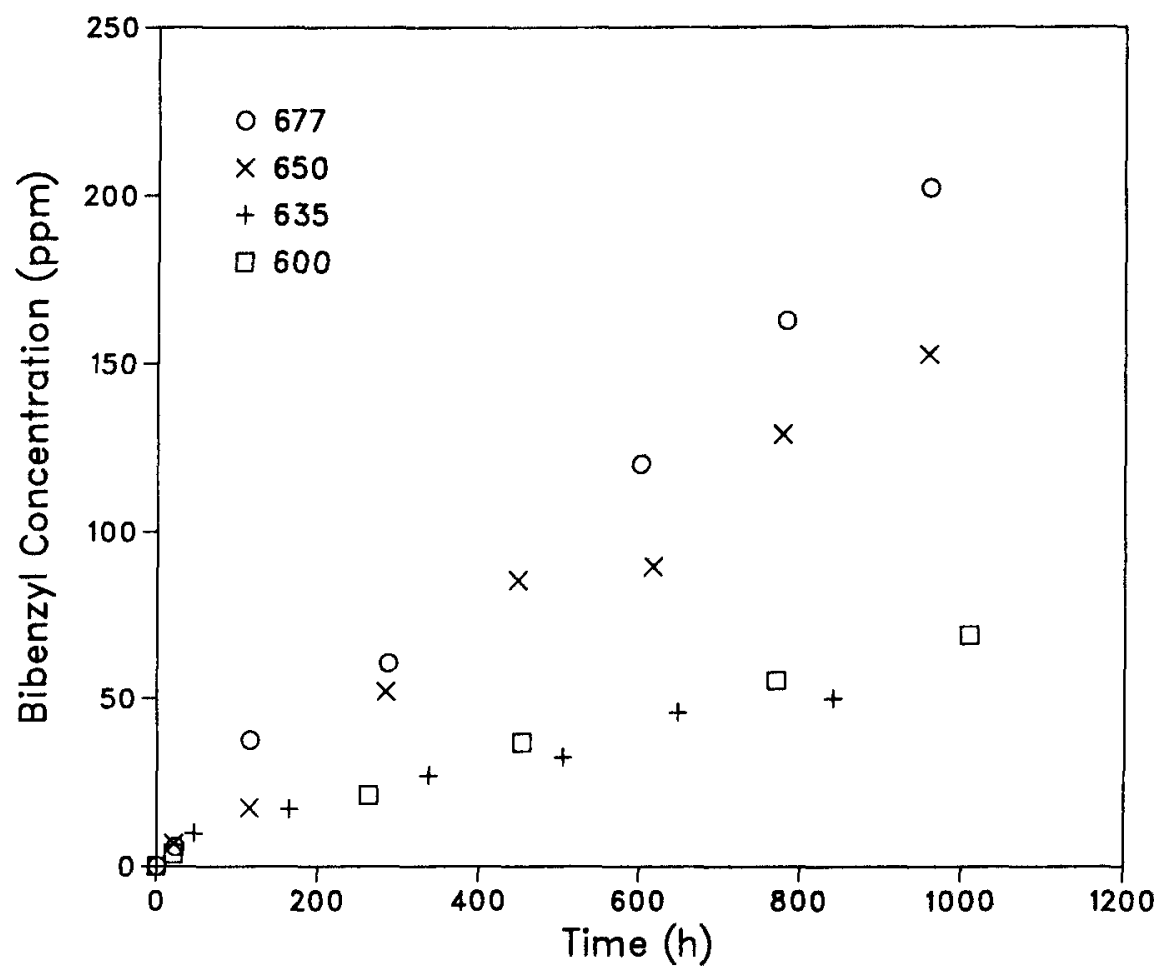

FIGURE 5.5 Bibenzyl Concentrations 


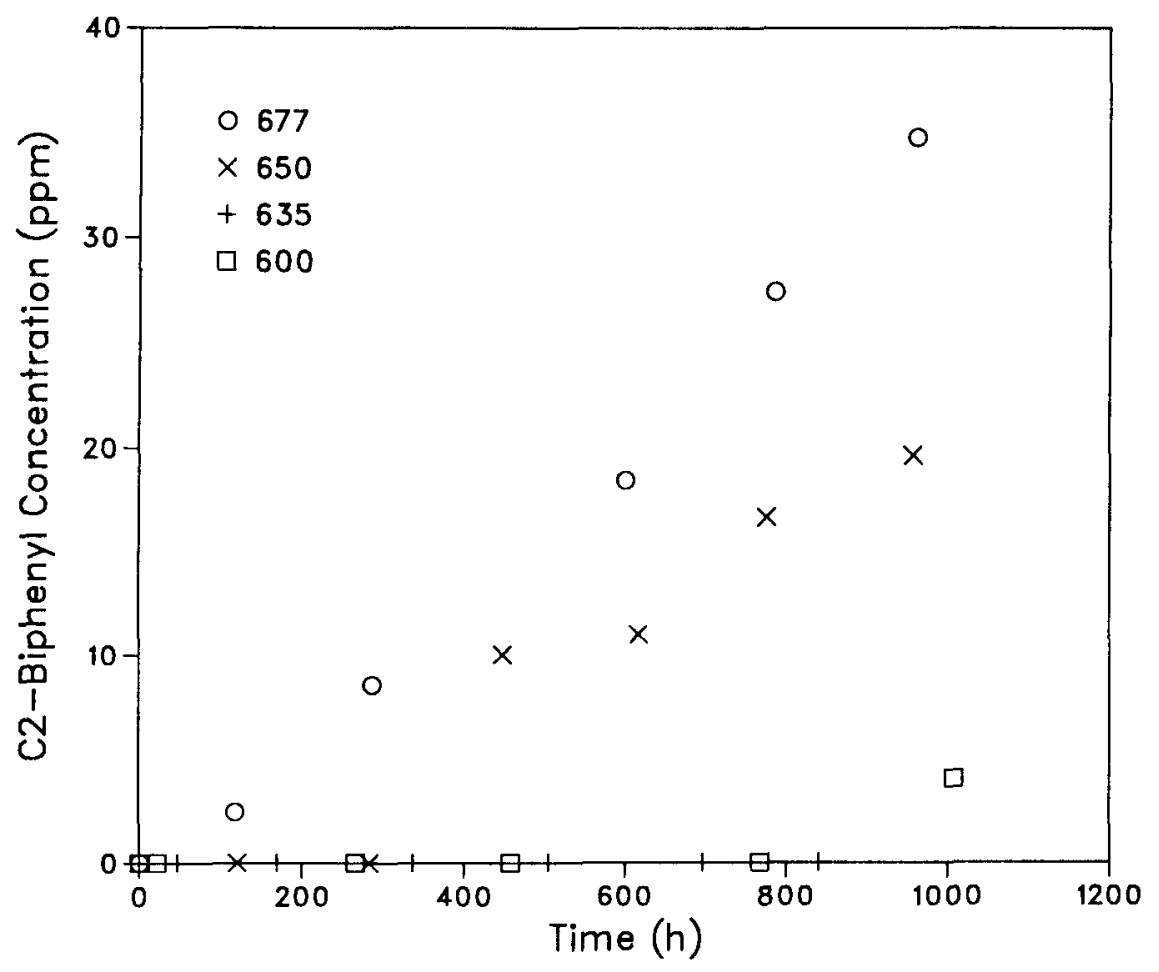

FIGURE 5.6 C2-Biphenyl Concentrations

exceeds that of C2-biphenyl, formation of bibenzyl must have a lower activation energy than formation of C2-biphenyl. At higher temperatures, however, the activation energy required for formation of $\mathrm{C2}$-biphenyl is overcome, and the C2-biphenyl might become more prevalent than bibenzyl. To check this hypothesis, we have plotted the ratios of C2-biphenyl concentration to bibenzyl concentration in Fig. 5.7. This figure shows that formation of C2-biphenyl does become more significant at higher temperatures.

\subsection{VAPOR-PHASE ANALYSIS}

\subsubsection{Toluene and Degradation Products}

Table 5.5 lists the vapor-phase concentrations of toluene degradation products in mole percent (mol \%). Because the total pressure in the capsules was not measured, absolute amounts of vapor-phase degradation products cannot be calculated. However, the data can be used to provide relative concentrations that can be compared under the different conditions studied. The data are presented at the four primary temperatures studied -- 600,635, 650, and $677^{\circ} \mathrm{F}--$ in ascending order of loop residence time. The main degradation products are hydrogen, methane, and C2 and C3 alkanes and alkenes. Because the $635^{\circ} \mathrm{F}$ test was run at a different evaporator pressure than the other tests, its vapor-phase analysis will be described after those of the other tests. 


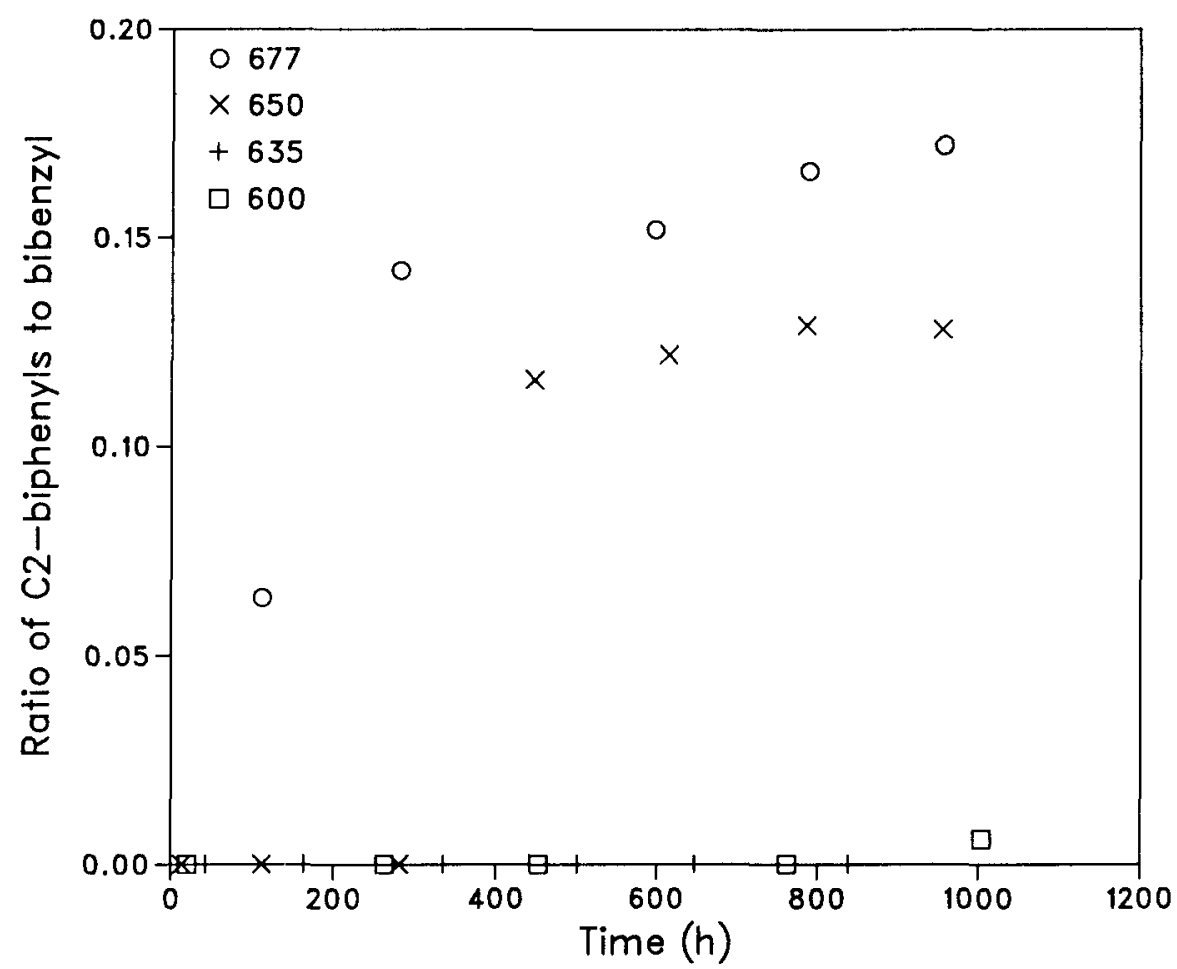

\section{FIGURE 5.7 Ratios of C2-Biphenyl Concentration to Bibenzyl Concentration}

The concentration of toluene in the vapor phase is also listed in Table 5.5. The vapor-phase concentration of toluene depends on the total pressure in the sample. The relative toluene concentration is highest when the total pressure is lowest, which occurs before degradation begins. Once degradation products are formed, the total vapor pressure in the sample increases, dramatically lowering the relative percent toluene in the vapor phase. For most samples, the toluene vapor-phase concentration is highest in the $600^{\circ} \mathrm{F}$ sample and decreases at each successively higher temperature. Three exceptions were observed, at $623 \mathrm{~h}\left(600^{\circ} \mathrm{F}\right)$ and at 955 and $1006 \mathrm{~h}\left(650^{\circ} \mathrm{F}\right)$. These samples show toluene concentrations of 23-32\%. These high values are probably due to some liquid toluene adhering to the Swagelok fitting on the capsule and then entering the mass spectrometer, where it was vaporized by the high source vacuum.

The hydrogen concentration is observed to increase rapidly at $600^{\circ} \mathrm{F}$ and then level off at $12-13 \mathrm{~mol} \%$. At $650^{\circ} \mathrm{F}$, this leveling off is also observed, but at $28-29 \mathrm{~mol}$ \%; the higher concentration is due to the greater degradation at the higher temperature. At $677^{\circ} \mathrm{F}$, no corresponding increase in hydrogen concentration is observed. The first sample, taken at $117 \mathrm{~h}$, shows almost 26 mol \% hydrogen and levels off at the same relative value $(28-29 \mathrm{~mol} \%)$ observed at $650^{\circ} \mathrm{F}$, although total degradation in the vapor phase is greater at the higher temperature. Above $30 \mathrm{~mol} \%$, apparently, the hydrogen is consumed in subsequent reactions with degradation products. Undoubtedly, the hydrogen would react with $\mathrm{C} 2$ and $\mathrm{C} 3$ ring fragments (HC$\mathrm{CH}$ and $\mathrm{HC}=\mathrm{CH}-\mathrm{CH}$ ) to form ethylene and propylene. These might react in another hydrogenation to form ethane and propane, respectively. All four of these degradation products are observed. 
TABLE 5.5 Toluene Degradation in the Vapor Phase

\begin{tabular}{|c|c|c|c|c|c|c|}
\hline \multirow[b]{2}{*}{ Temp. $\left({ }^{\circ} \mathrm{E}\right)$} & \multirow[b]{2}{*}{$\begin{array}{l}\text { Loop } \\
\text { Time } \\
\text { (h) }\end{array}$} & \multicolumn{3}{|c|}{ Toluene and Degradation } & \multicolumn{2}{|c|}{ Products (mol \%) } \\
\hline & & Hydrogen & Methane & $\begin{array}{l}\mathrm{C}_{2} \mathrm{H}_{4}, \\
\mathrm{C}_{2} \mathrm{H}_{6}, \\
\mathrm{c}_{3} \mathrm{H}_{6}, \\
\mathrm{C}_{3} \mathrm{H}_{8},\end{array}$ & $\begin{array}{l}\text { Total } \\
\text { Gaseous } \\
\text { Degrad- } \\
\text { ation }\end{array}$ & Toluene \\
\hline \multicolumn{7}{|l|}{600} \\
\hline & $\begin{array}{r}23 \\
266 \\
455 \\
623 \\
766 \\
938 \\
1006\end{array}$ & $\begin{array}{r}2.6 \\
9.7 \\
13.7 \\
17.8 \\
12.6 \\
11.8 \\
12.1\end{array}$ & $\begin{array}{l}0.8 \\
3.0 \\
3.4 \\
2.3 \\
1.2 \\
1.4 \\
1.6\end{array}$ & $\begin{array}{l}4.1 \\
6.4 \\
4.7 \\
3.2 \\
1.7 \\
1.0 \\
1.9\end{array}$ & $\begin{array}{r}7.5 \\
19.1 \\
21.8 \\
23.3 \\
15.5 \\
14.2 \\
15.6\end{array}$ & $\begin{array}{r}19.3 \\
12.0 \\
14.7 \\
25.7 \\
11.7 \\
9.9 \\
14.7\end{array}$ \\
\hline \multicolumn{7}{|l|}{635} \\
\hline & $\begin{array}{r}45 \\
168 \\
338 \\
504 \\
649 \\
840\end{array}$ & $\begin{array}{r}7.2 \\
15.7 \\
22.1 \\
22.1 \\
28.4 \\
\text { NA }^{a}\end{array}$ & $\begin{array}{l}1.3 \\
3.9 \\
6.5 \\
8.5 \\
8.2 \\
\text { NA }\end{array}$ & $\begin{array}{l}2.2 \\
6.7 \\
6.2 \\
7.1 \\
5.5 \\
\text { NA }\end{array}$ & $\begin{array}{c}10.7 \\
26.3 \\
34.8 \\
37.7 \\
42.1 \\
\text { NA }\end{array}$ & $\begin{array}{r}6.9 \\
7.9 \\
17.6 \\
7.3 \\
8.0 \\
\text { NA }\end{array}$ \\
\hline \multicolumn{7}{|l|}{650} \\
\hline & $\begin{array}{r}19 \\
115 \\
282 \\
450 \\
619 \\
786 \\
955 \\
1006\end{array}$ & $\begin{array}{r}2.0 \\
14.8 \\
25.9 \\
27.8 \\
29.8 \\
33.1 \\
21.5 \\
29.6\end{array}$ & $\begin{array}{l}0.3 \\
4.2 \\
5.5 \\
5.9 \\
6.3 \\
6.2 \\
3.5 \\
4.2\end{array}$ & $\begin{array}{l}0.4 \\
3.3 \\
5.3 \\
6.2 \\
5.3 \\
4.4 \\
7.8 \\
4.8\end{array}$ & $\begin{array}{r}2.7 \\
22.3 \\
36.7 \\
39.9 \\
41.4 \\
43.7 \\
32.8 \\
38.6\end{array}$ & $\begin{array}{r}4.0 \\
8.3 \\
7.2 \\
10.6 \\
8.2 \\
9.3 \\
32.4 \\
23.0\end{array}$ \\
\hline \multicolumn{7}{|l|}{677} \\
\hline & $\begin{array}{l}117 \\
285 \\
452 \\
600 \\
789 \\
958\end{array}$ & $\begin{array}{l}25.8 \\
28.6 \\
28.2 \\
28.8 \\
24.9 \\
28.3\end{array}$ & $\begin{array}{l}11.7 \\
17.1 \\
19.9 \\
16.4 \\
15.9 \\
16.9\end{array}$ & $\begin{array}{r}8.0 \\
11.9 \\
11.4 \\
13.2 \\
10.0 \\
10.9\end{array}$ & $\begin{array}{l}45.5 \\
57.6 \\
59.5 \\
58.4 \\
50.8 \\
56.1\end{array}$ & $\begin{array}{l}4.9 \\
7.1 \\
5.4 \\
7.1 \\
7.5 \\
8.0\end{array}$ \\
\hline
\end{tabular}

$a_{\mathrm{NA}}=$ not analyzed. 
The relative methane concentration is also constant at each degradation temperature. At $600^{\circ} \mathrm{F}$, the relative concentration is $1-3 \mathrm{~mol} \%$. At $650^{\circ} \mathrm{F}$, the concentration increases to 5-6 mol \%, which further increases to $17-19 \mathrm{~mol} \%$ at $677^{\circ} \mathrm{F}$. Methane is formed when a methyl radical reacts with a hydrogen atom. Unlike the hydrogen concentration, the relative methane concentration at $677^{\circ} \mathrm{F}$ is greater than that at $650^{\circ} \mathrm{F}$. This is expected, because methane is much less reactive than hydrogen and does not undergo the addition and reduction reactions that hydrogen does.

The C2 and C3 alkanes and alkenes -- ethane, ethylene, propane, and propylene -would be formed by cleavage of the aromatic ring. The fact they are present at low concentration at $600^{\circ} \mathrm{F}$ proves that there are small amounts of ring cleavage even at this low temperature. They are also present at a level relative concentration at each temperature. As is the case for methane, at each temperature they are at a higher relative concentration level. At $600^{\circ} \mathrm{F}$, their relative concentration is greater than the methane concentration, but the reverse is true at $677^{\circ} \mathrm{F}$.

The ratio of the relative concentration of methane to ethanes and propanes is important. When the ring cleaves, two $\mathrm{C} 3$ or three $\mathrm{C2}$ fragments can be formed in addition to methane. Alternatively, if no methane is formed, ring cleavage will produce two C2 and one C3 ring fragments. Both fragmentation patterns would be taking place; in both cases, however, the concentration of $\mathrm{C2}$ and $\mathrm{C3}$ products would be greater than that of methane, as is the case at $600^{\circ} \mathrm{F}$. Hence, the greater relative methane concentration at $677^{\circ} \mathrm{F}$ must be due to the formation of methane by an additional mechanism, most probably by cleavage of the bond between the ring carbon and the methyl carbon.

The "total gaseous degradation" column in Table 5.5 sums the concentrations of hydrogen, methane, and $\mathrm{C} 2$ and $\mathrm{C} 3$ alkanes and alkenes. In each case this total relative concentration is greater at greater temperature. Degradation products consist of just under $60 \mathrm{~mol} \%$ of the vapor phase at a loop temperature of $677^{\circ} \mathrm{F}$.

Because degradation data at $635^{\circ} \mathrm{F}$ were obtained with a different evaporator pressure than in the other tests, these data are not directly comparable with the other data presented. However, the $635^{\circ} \mathrm{F}$ data show strong similarities to the data obtained at $650^{\circ} \mathrm{F}$. About $40 \mathrm{~mol} \%$ total degradation products occur in the vapor phase. The major degradation product is hydrogen, with the leveling off taking place at 22-28 mol \% (a little lower than at $650^{\circ} \mathrm{F}$ ). One major difference is that more than $8 \%$ methane was formed; at $650^{\circ} \mathrm{F}$, relative methane concentration was 5-6 mol \%. C2 and C3 alkane and alkene concentration was identical at both temperatures. It appears that reduced pressure slightly favors methane production over hydrogen. The data are presented in Table 5.5.

\subsubsection{Other Vapor-Phase Components}

The remaining $40 \mathrm{~mol} \%$ of the vapor phase consists of carbon dioxide, nitrogen, carbon monoxide, oxygen, helium, and argon. Data on the relative concentrations of these vapor-phase components are presented in Table 5.6. Small quantities of argon are 
TABLE 5.6 Relative Concentration of Background and Oxygen-Containing Components in the Vapor Phase

\begin{tabular}{|c|c|c|c|c|c|c|c|}
\hline \multirow[b]{2}{*}{ Temp. $\left({ }^{\circ} \mathrm{F}\right)$} & \multirow[b]{2}{*}{$\begin{array}{l}\text { Loop } \\
\text { Time } \\
(\mathrm{h})\end{array}$} & \multicolumn{6}{|c|}{ Components (mol \%) } \\
\hline & & $\begin{array}{r}\text { Carbon } \\
\text { Dioxide }\end{array}$ & $\begin{array}{c}\text { Nitrogen } \\
\text { and } \\
\text { Carbon } \\
\text { Monoxide }\end{array}$ & Oxygen & Water & Helium & Argon \\
\hline \multicolumn{8}{|l|}{600} \\
\hline & $\begin{array}{r}23 \\
266 \\
455 \\
623 \\
766 \\
938 \\
1006\end{array}$ & $\begin{array}{l}2.8 \\
5.7 \\
5.0 \\
3.1 \\
1.9 \\
4.0 \\
3.1\end{array}$ & $\begin{array}{r}9.2 \\
23.0 \\
37.3 \\
30.4 \\
54.6 \\
65.6 \\
58.2\end{array}$ & $\begin{array}{l}0.10 \\
0.05 \\
1.30 \\
0.40 \\
8.60 \\
1.20 \\
5.00\end{array}$ & $\begin{array}{l}0.1 \\
0.1 \\
0.1 \\
0.1 \\
0.0 \\
0.0 \\
0.1\end{array}$ & $\begin{array}{r}60.9 \\
39.9 \\
19.5 \\
16.7 \\
7.0 \\
4.2 \\
2.7\end{array}$ & $\begin{array}{l}0.04 \\
0.17 \\
0.40 \\
0.40 \\
0.70 \\
0.80 \\
0.60\end{array}$ \\
\hline \multicolumn{8}{|l|}{635} \\
\hline & $\begin{array}{r}45 \\
168 \\
338 \\
504 \\
649 \\
840\end{array}$ & $\begin{array}{l}5.7 \\
7.9 \\
7.6 \\
9.4 \\
8.0 \\
\mathrm{NA}^{\mathrm{a}}\end{array}$ & $\begin{array}{c}71.2 \\
54.6 \\
38.1 \\
44.2 \\
41.2 \\
\text { NA }\end{array}$ & $\begin{array}{l}1.20 \\
0.60 \\
0.60 \\
0.40 \\
0.80 \\
\text { NA }\end{array}$ & $\begin{array}{l}0.2 \\
0.2 \\
0.1 \\
0.1 \\
0.2 \\
\text { NA }\end{array}$ & $\begin{array}{r}0 \\
0 \\
0 \\
0 \\
0 \\
\mathrm{NA}\end{array}$ & $\begin{array}{l}4.20 \\
2.50 \\
1.50 \\
0.90 \\
0.40 \\
\mathrm{NA}\end{array}$ \\
\hline \multicolumn{8}{|l|}{650} \\
\hline & $\begin{array}{r}19 \\
115 \\
282 \\
450 \\
619 \\
786 \\
955 \\
1006\end{array}$ & $\begin{array}{l}2.4 \\
9.7 \\
9.0 \\
8.4 \\
7.0 \\
6.2 \\
4.2 \\
3.4\end{array}$ & $\begin{array}{r}6.9 \\
19.4 \\
29.9 \\
33.9 \\
38.9 \\
38.4 \\
27.2 \\
33.3\end{array}$ & $\begin{array}{l}0.05 \\
0.05 \\
0.10 \\
0.10 \\
0.20 \\
0.10 \\
2.00 \\
0.60\end{array}$ & $\begin{array}{l}0.0 \\
0.1 \\
0.0 \\
0.0 \\
0.0 \\
0.1 \\
0.3 \\
0.1\end{array}$ & $\begin{array}{r}83.9 \\
40.1 \\
16.7 \\
7.4 \\
4.0 \\
1.8 \\
0.7 \\
0.8\end{array}$ & $\begin{array}{l}0.05 \\
0.07 \\
0.18 \\
0.20 \\
0.30 \\
0.40 \\
0.40 \\
0.30\end{array}$ \\
\hline \multicolumn{8}{|l|}{677} \\
\hline & $\begin{array}{l}117 \\
285 \\
452 \\
600 \\
789 \\
958\end{array}$ & $\begin{array}{l}8.4 \\
9.7 \\
9.5 \\
8.5 \\
7.4 \\
7.7\end{array}$ & $\begin{array}{l}19.1 \\
21.3 \\
23.1 \\
23.4 \\
26.6 \\
26.2\end{array}$ & $\begin{array}{l}0.01 \\
0.01 \\
0.05 \\
0.30 \\
0.50 \\
0.40\end{array}$ & $\begin{array}{l}0.1 \\
0.0 \\
0.0 \\
0.1 \\
0.1 \\
0.1\end{array}$ & $\begin{array}{r}21.9 \\
4.2 \\
2.4 \\
2.1 \\
7.0 \\
1.3\end{array}$ & $\begin{array}{l}0.06 \\
0.10 \\
0.10 \\
0.17 \\
0.12 \\
0.19\end{array}$ \\
\hline
\end{tabular}

${ }^{a} \mathbf{N A}=$ not analyzed. 
present because it is used to purge the system of air. Helium is used to check the loop for leaks, and some residual amount would be expected to remain in the loop after pumpdown. The mole percent of helium is high in low-hour samples because the total pressure is low, and the low concentration of helium divided by its low molecular weight results in a high mole percent. As the pressure increases (due to the formation of degradation products), the relative concentration of helium decreases, although the mass of helium present in the loop is constant.

Because of the reactivity of oxygen with toluene at elevated temperatures, the concentration of oxygen in the vapor-phase sample should be very low, less than 1 mol $\%$. This is the case for all but four samples. The presence of oxygen at greater than 1 mol \% relative concentration in these samples indicates that the capsule leaked air after removal from the loop and before analysis.

Because the mass spectrometer cannot differentiate the slight difference in mass between molecular nitrogen and carbon monoxide, the concentrations of these components are combined in a single column. This complicates detection of air leakage into the loop, because the presence of nitrogen indicates air incursion into the loop, whereas carbon monoxide and carbon dioxide can be formed from oxygen-containing impurities in the toluene (especially ethers). If an air incursion into the loop occurred, the reaction of oxygen with toluene would produce oxidation products, such as benzaldehyde (which is observed), that could in turn degrade to form carbon monoxide and carbon dioxide.

The low concentration of benzaldehyde in the liquid phase implies that there must be some air incursion. However, the low concentration also indicates that the incursion is slight. Undoubtedly, some of the carbon monoxide and carbon dioxide can be attributed to this source. Some of the $\mathrm{CO}$ and $\mathrm{CO}_{2}$ is also due to the oxygen-containing impurities that were present in the initial charge of toluene. The concentration of carbon dioxide is only 7-9 mol \% of the total in most samples. Nitrogen and carbon monoxide concentrations combined are quite high, amounting to 20-35 mol \% relative concentration in most samples. If an air incursion into the hydrogen-rich atmosphere of the loop occurs, water should be formed. In all cases, the concentration of water is exceptionally low $(0.1 \mathrm{~mol} \%)$, so air leakage into the loop is insignificant.

The relative concentration of background and oxygen-containing components for the $635^{\circ} \mathrm{F}$ test is similar to that of the other samples. Carbon dioxide concentration was 8-9 mol \%. Oxygen concentration was higher by 25\%. This extra oxygen probably resulted from air incursion, because the relative concentration of nitrogen and carbon monoxide was higher than that in all the other samples that had no vapor sample-capsule leak. Indeed, some of the packed-stem valves in the low-pressure areas of the loop were replaced with bellows-seal valves after the $635^{\circ} \mathrm{F}$ test, because a small air leak was suspected. The water concentration, though low, was double that of the other samples. From the data, it appears that the air incursion was at a low level. This is supported by slightly higher values for benzaldehyde concentration in the liquid phase. Data are presented in Table 5.6. 


\subsection{RELATION OP THE ARRHENIUS EQUATION TO DEGRADATION}

The Arrhenius equation (Eq. 5.17) relates the reaction rate $R$ for a chemical reaction to absolute temperature through the constants $R_{0}$ and $K$. Two problems arise in relating the Arrhenius equation to ORC system degradation: (1) The total degradation in the system is the sum of components from many different chemical reactions, and (2) the temperature in the system varies from point to point.

$$
R=R_{0} e^{-K / T} \text { abs }
$$

To be strictly correct, the Arrhenius equation can be applied only for individual chemical reactions, and many reactions are involved in toluene degradation. In the previous section we showed that formation of bibenzyl is by far the dominant reaction for the conditions of our tests. Therefore, we approximate the total degradation rate by a single Arrhenius equation with unknown constants $R_{0}$ and $K$. The object of these experiments is to determine the two constants and to relate the Arrhenius equation to degradation in an ORC system. The result will be valid if formation of bibenzyl is the dominant reaction. If higher operating temperatures -- where other reactions such as formation of C2-biphenyls become important -- are required, then it will be necessary to perform additional research, calculate a second set of constants, and sum the degradations from the two important reactions.

The fluid-dynamic continuity equation (Eq. 5.18) is used to determine a relationship between residence time and position in the system. Figure 5.8 shows a control volume having a mass flow $\dot{m}$ passing through it with cross-sectional area $\mathrm{A}(\mathrm{x})$, fluid temperature $T(x)$, fluid pressure $p(x)$, and fluid density $\rho(p, T)$ at location $x$ in the system. At $x$, the fluid velocity is $u(x)$.

$$
\dot{\mathrm{m}}=\rho(\mathrm{p}, \mathrm{T}) \mathrm{A}(\mathrm{x}) \mathrm{u}(\mathrm{x})
$$

The fact that $u(x)=d x / d t$ gives a relationship between time and position in the system:

$$
d t=\frac{\rho(p, T) A(x)}{\dot{m}} d x
$$

Equation 5.19 also imposes the mathematical constraint that the mass flow rate not be zero.

The total degradation is the integral of the rate of degradation with respect to time; using Eg. 5.19 in the integral gives the degradation for one circuit around the system $D_{1}$, where $L$ is the length of the circuit:

$$
\mathrm{D}_{1}=\frac{\mathrm{R}_{\mathrm{o}}}{\dot{\mathrm{m}}} \int_{0}^{\mathrm{L}} \mathrm{e}^{-\mathrm{K} / \mathrm{T}} \mathrm{abs} \rho(\mathrm{p}, \mathrm{T}) \mathrm{A}(\mathrm{x}) \mathrm{dx}
$$


The duration of system operation $\mathrm{t}_{\mathrm{D}}$ and the total mass $\mathrm{m}$ of the fluid are known. Therefore, the number of circuits $\mathrm{n}$ made by the fluid during system operation is given by Eq. 5.21 :

$$
\mathrm{n}=\frac{\dot{\mathrm{m}} \mathrm{t}}{\mathrm{m}}
$$

Finally, since the total degradation $\mathrm{D}_{\mathrm{T}}$ is equal to $\mathrm{nD}_{1}$, one obtains the following expression:

$$
D_{T}=\frac{R_{0} t_{D}}{m} \int_{0}^{L} e^{-K / T} \text { abs } \rho(p, T) A(x) d x
$$

The integral of Eq. 5.22 was evaluated from arbitrary location $x_{1}$ to $x_{2}$ in the system, assuming linear changes of temperature and density and constant cross-sectional area. The resulting degradation from point 1 to point 2 is

$$
\begin{aligned}
& \mathrm{D}_{1,2}=\frac{\mathrm{t}_{0} \mathrm{R}_{0} \mathrm{~A}}{\mathrm{~m}}\left(\frac{\mathrm{x}_{2}-\mathrm{x}_{1}}{\mathrm{~T}_{2}-\mathrm{T}_{1}}\right)\left\{[ \rho _ { 1 } - ( \frac { \rho _ { 2 } - \rho _ { 1 } } { \mathrm { T } _ { 2 } - \mathrm { T } _ { 1 } } ) ( \mathrm { T } _ { 1 } + \frac { \mathrm { K } } { 2 } ) ] \left[\mathrm{T}_{2} \mathrm{e}^{-\frac{\mathrm{K}}{\mathrm{T}_{2}}}-\mathrm{T}_{1} \mathrm{e}^{-\frac{\mathrm{K}}{\mathrm{T}_{1}}}\right.\right. \\
& \left.\left.-\mathrm{K}\left(\mathrm{E}_{1}\left(\frac{\mathrm{K}}{\mathrm{T}_{2}}\right)-\mathrm{E}_{1}\left(\frac{\mathrm{K}}{\mathrm{T}}\right)\right)\right]+\frac{1}{2}\left(\frac{\rho_{2}-\rho_{1}}{\mathrm{~T}_{2}-\mathrm{T}_{1}}\right)\left[\mathrm{T}_{2}{ }^{2} \mathrm{e}^{-\frac{\mathrm{K}}{\mathrm{T}_{2}}}-\mathrm{T}_{1}{ }^{2} \mathrm{e}^{-\frac{\mathrm{K}}{\mathrm{T}}} 1\right]\right\}
\end{aligned}
$$

where $E_{1}(x)$ is defined and tabulated in Sec. 5 of Handbook of Mathematical Functions. 14 Although the mass flow rate was used to derive Eq. 5.23, it does not appear in the equation; nevertheless, it cannot be zero. Physically, this makes sense, because a fraction of the fluid in the system occupies each small section of the system and degrades at a rate prescribed by the temperature of that section. It does not matter whether the flow rate is low or high, because the same fraction of fluid occupies that particular section regardless of the flow rate. However, if the flow rate were zero, the fluid in the hottest parts of the system would be totally degraded, while the fluid in the coolest parts of the system would have little degradation. Equation $\mathbf{5 . 2 3}$ is written as the short BASIC program shown in App. E.

\subsection{DETERMINATION OF COEFFICIENTS FROM EXPERIMENTAL DATA}

Coefficients of the Arrhenius equation are determined by adjusting the coefficients $R_{o}$ and $K$ to minimize the sum of the squares of the differences between measured and predicted degradations (i.e., the least-square error). A modified version of the computer program shown in App. $E$ is used for the calculations. Data from the four 
tests performed at Argonne were fitted in this manner and used to predict the degradation for a test at $750^{\circ} \mathrm{F}$ performed by Sundstrand Corp. for the National Aeronautics and Space Administration (NASA). 15

Both the computer program shown in App. $E$ and the program that fits $R_{o}$ and $K$ to the data require temperature and density data. The temperatures are determined from thermocouples located at various positions in the evaporator and other hot parts of the loop. These measured temperatures are plotted as a function of location in the loop in Figs. 5.9-5.13; the zero datum is at the inlet of the evaporator. Fluid densities are determined from the temperatures and the state (liquid or vapor) from tabulated thermodynamic-property data. The least-square fit gives values of $R_{0}=9.9917 \times 10^{9}$ $\mathrm{ppm} / \mathrm{h}$ and $\mathrm{K}=23,056^{\circ} \mathrm{R}$.

The predicted and measured degradations for the tests are compared in Table 5.7. Test run no. $1\left(635^{\circ} \mathrm{F}\right)$ shows a $23 \%$ error, while the other Argonne tests show 6-7\% errors. There are two reasons why the error for test run no. 1 should be larger than the error for the other Argonne tests:

1. Because of a problem with the data logger during test run no. 1, the measured temperatures are not as accurate as they are for the other tests.

2. Test run no. 1 was operated at a substantially different evaporator pressure than the other tests ( 160 psia vs. 500 psia).

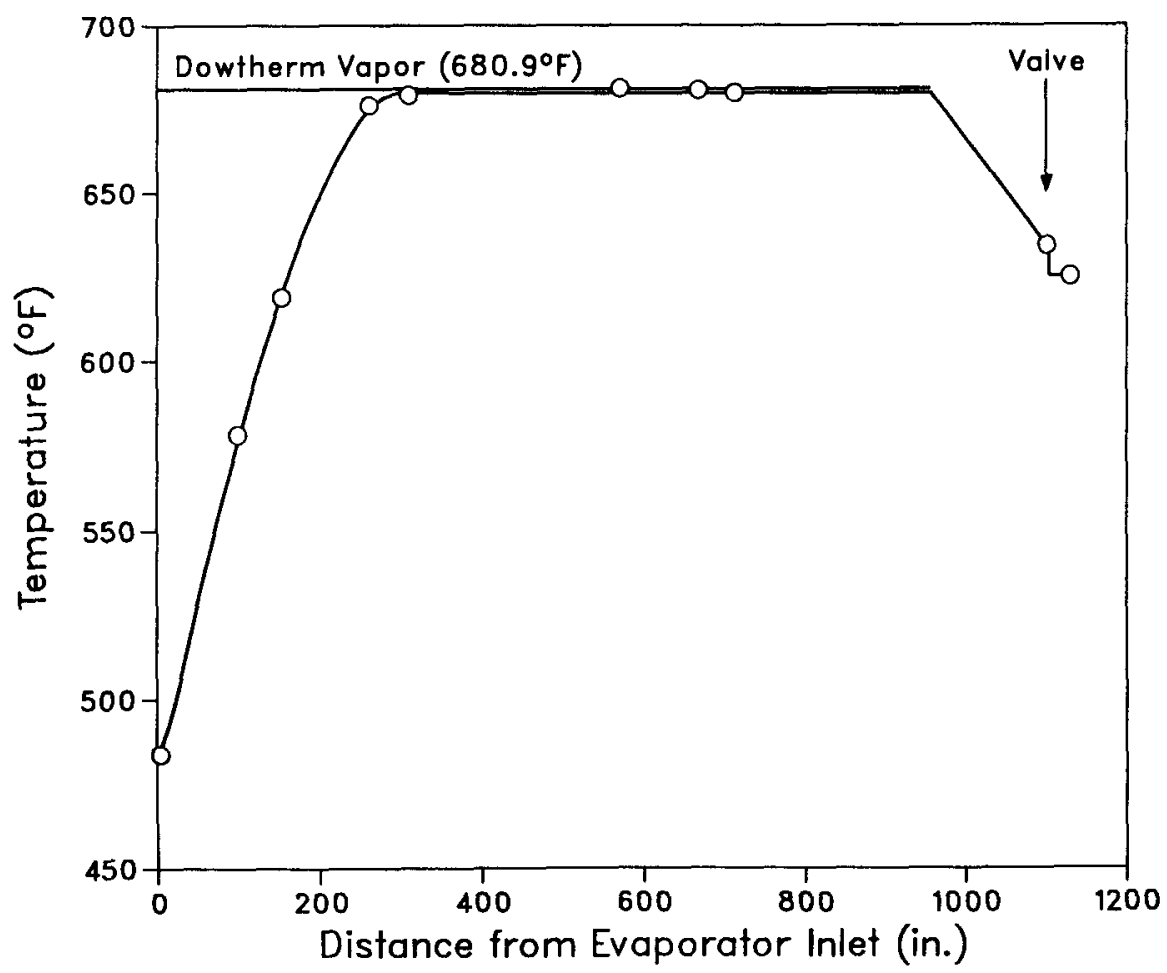

FIGURE 5.9 Temperature versus Position for Test No. $1\left(635^{\circ} \mathrm{F}\right)$ 


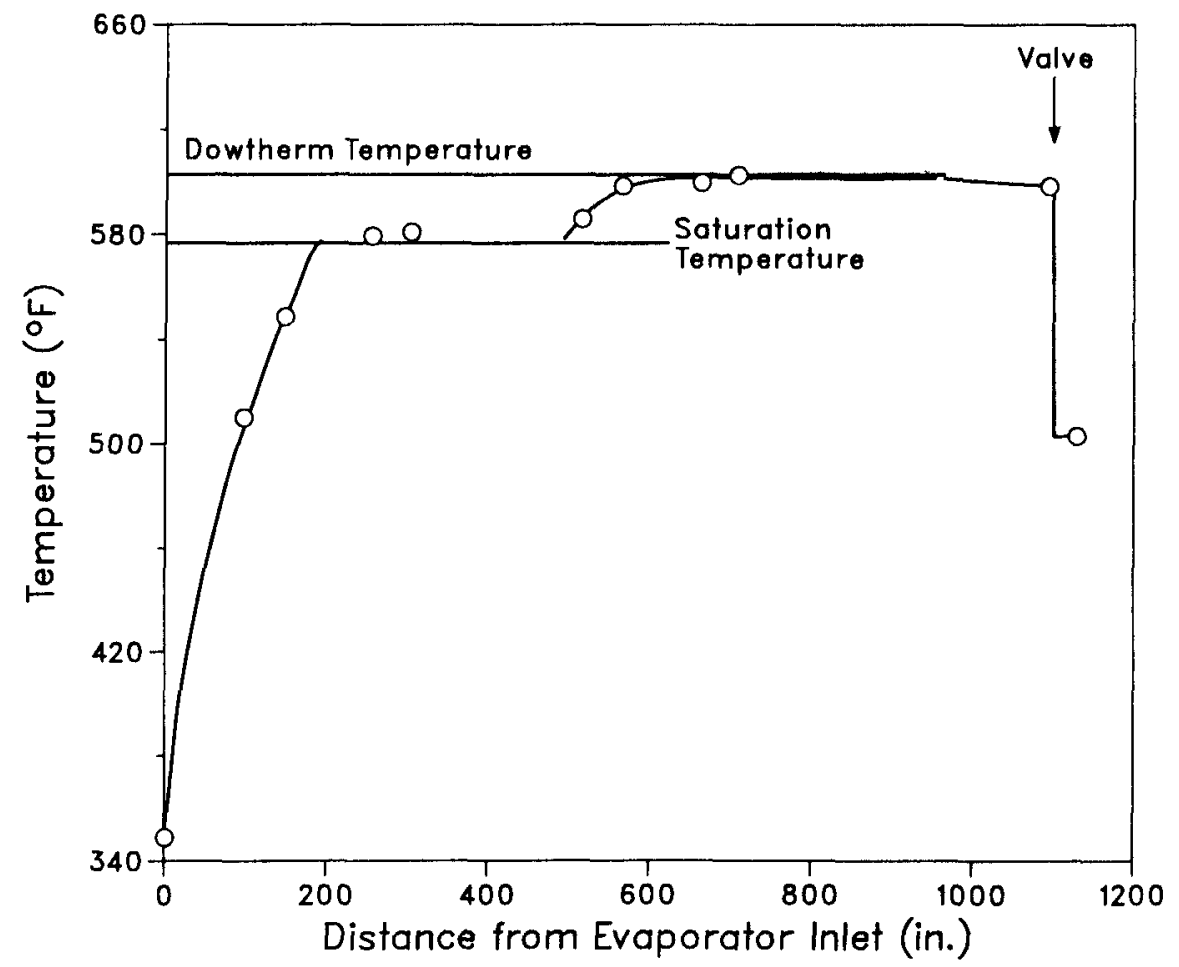

FIGURE 5.10 Temperature versus Position for Test No. $2\left(600^{\circ} \mathrm{F}\right)$

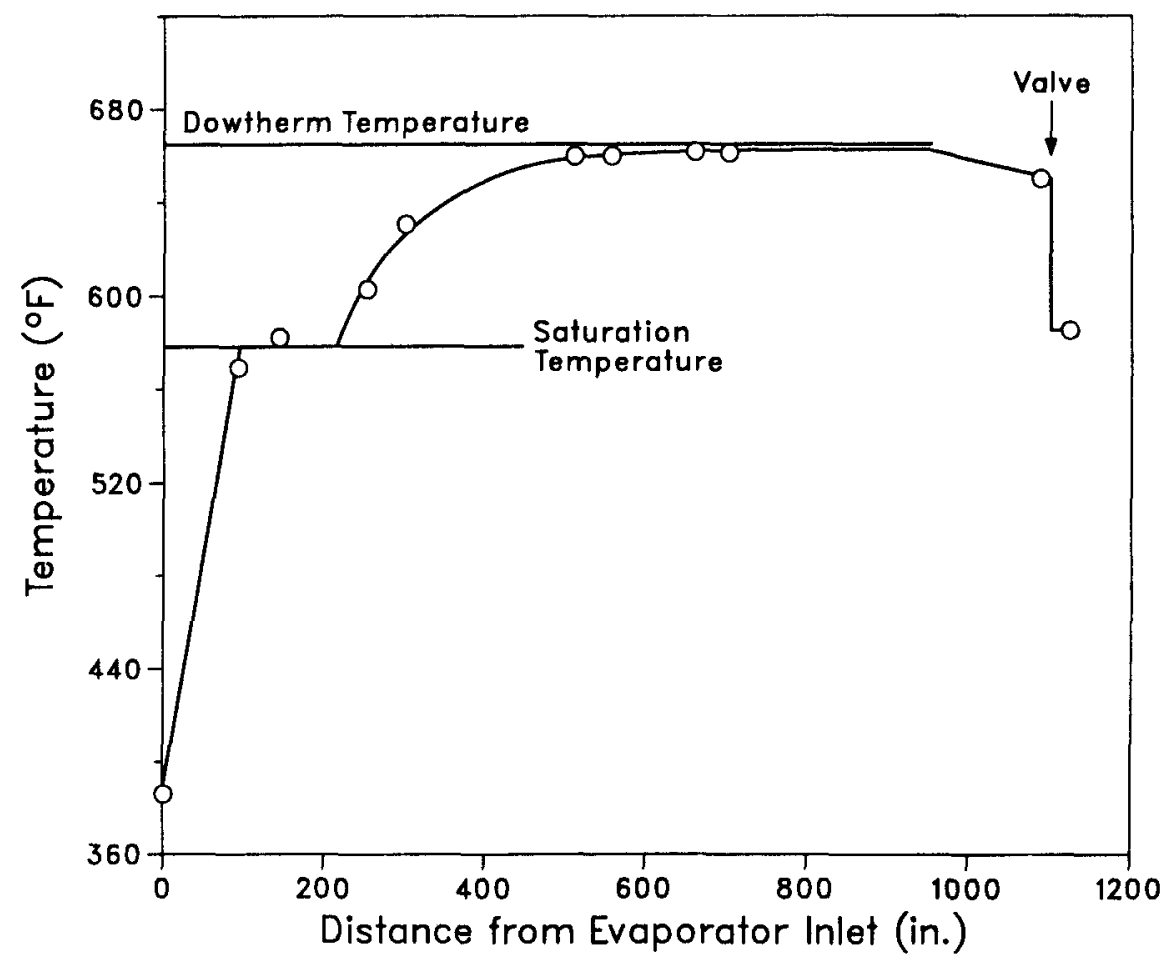

FIGURE 5.11 Temperature versus Position for Test No. $3\left(650^{\circ} \mathrm{F}\right)$ 


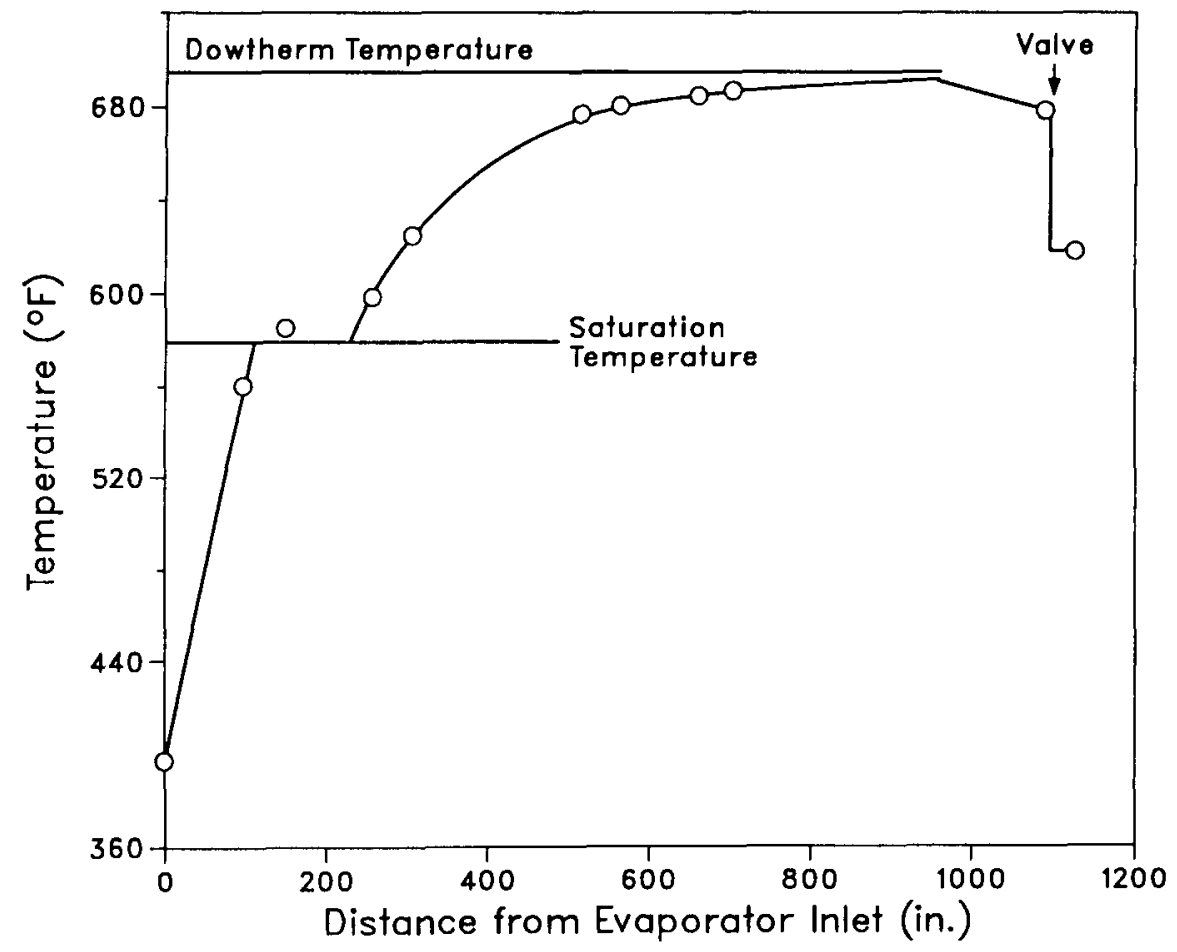

FIGURE 5.12 Temperature versus Position for Test No. $4\left(677^{\circ} \mathrm{F}\right)$

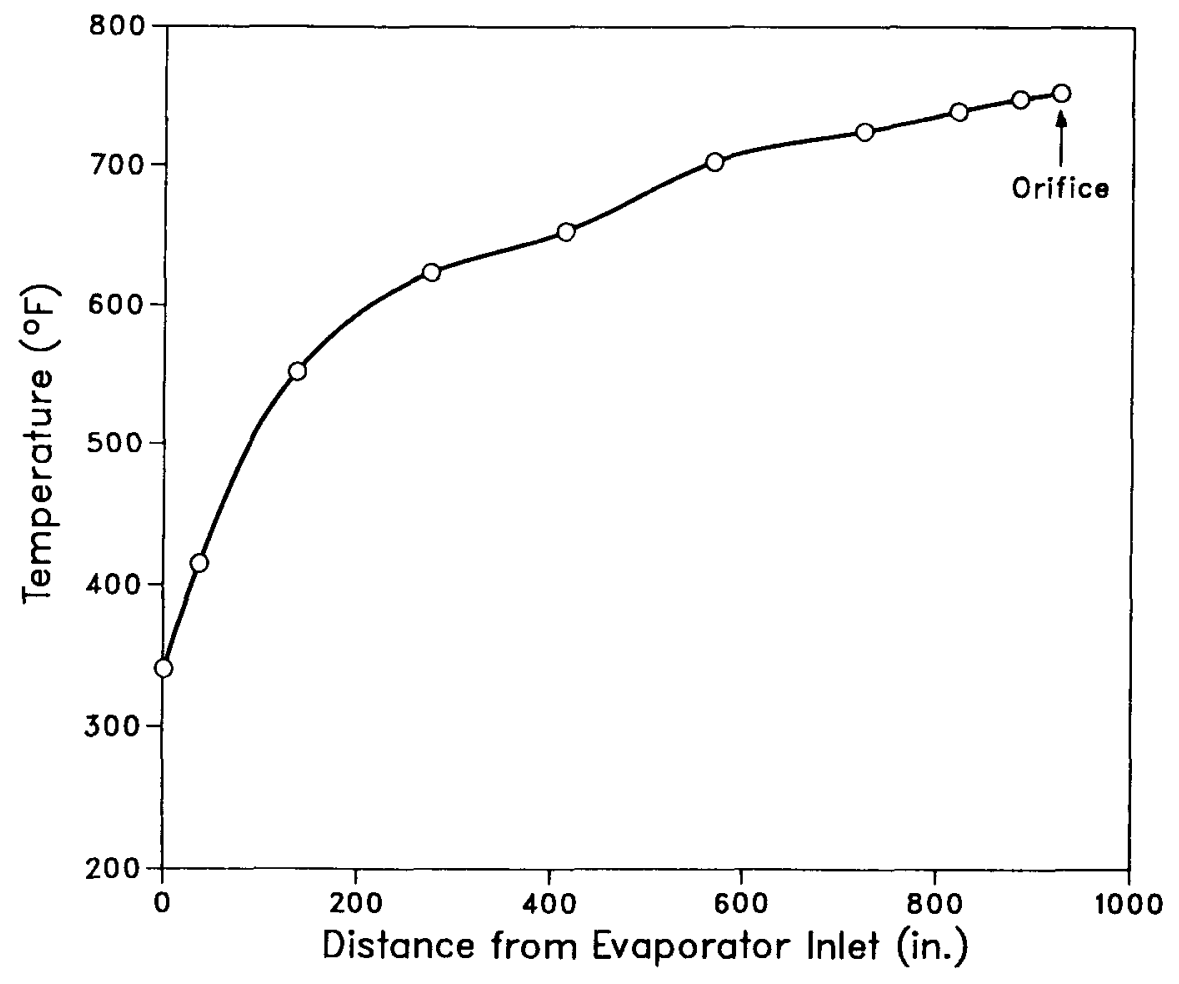

FIGURE 5.13 Temperature versus Position for Sundstrand/NASA Test $\left(750^{\circ} \mathrm{F}\right)$ 
TABLE 5.7 Comparison of Predicted and Measured Degradation for Single-Reaction Model

\begin{tabular}{ccccr}
\hline Test & $\begin{array}{c}\text { Nominal } \\
\text { Temp. }\left({ }^{\circ} \mathrm{F}\right)\end{array}$ & $\begin{array}{c}\text { Predicted } \\
\text { Degradation } \\
(\mathrm{ppm})\end{array}$ & $\begin{array}{c}\text { Measured } \\
\text { Degradation } \\
(\mathrm{ppm})\end{array}$ & $\begin{array}{c}\text { Error } \\
(\%)\end{array}$ \\
\hline 1 & 635 & 58.90 & 76.3 & -23 \\
2 & 600 & 111.82 & 105.4 & +6 \\
3 & 650 & 210.97 & 228.0 & -7 \\
4 & 677 & 260.94 & 246.0 & +6 \\
$\begin{array}{c}\text { Sundstrand/ } \\
\text { NASA }\end{array}$ & 750 & 641.17 & 1212.9 & -47 \\
\hline
\end{tabular}

The Sundstrand/NASA test shows a much larger error of $47 \%$. The main reason for this error is that a second chemical reaction leading to the formation of C2-biphenyl (Eqs. 5.4 and 5.13) is as important as the reaction leading to the formation of bibenzyl (Eqs. 5.2 and 5.5) on which the computation of the coefficients is based. Other possible reasons for the larger error include the following:

1. The Sundstrand/NASA test was operated at supercritical pressure, whereas the Argonne tests were operated at subcritical pressures.

2. The temperatures in the Sundstrand/NASA loop were not measured directly; instead, they were inferred from temperatures measured on the outside of the evaporator tube.

To determine whether the two-reaction hypothesis is correct, we determined the degradation due to methyl-group activation (Eq. 5.2) and ring activation (Eq. 5.4) for each of the tests, including the Sundstrand/NASA test, and determined the best fits of $R_{o}$ and $K$ for each reaction separately. For the methyl-group activation reaction, we obtained $R_{0}=3.6442 \times 10^{11} \mathrm{ppm} / \mathrm{h}$ and $\mathrm{K}=27,163^{\circ} \mathrm{R}$; for the ring activation reaction, we obtained $R_{o}=3.9485 \times 10^{30} \mathrm{ppm} / \mathrm{h}$ and $\mathrm{K}=79,215^{\circ} \mathrm{R}$. Predictions based on these values are listed, together with measured values, in Table 5.8. 
TABLE 5.8 Predicted and Measured Degradation for Two-Reaction Model

\begin{tabular}{|c|c|c|c|c|c|c|c|c|c|}
\hline \multirow[b]{2}{*}{ Test } & \multicolumn{3}{|c|}{ Methyl-Group Activation } & \multicolumn{3}{|c|}{ Ring Activation } & \multicolumn{3}{|c|}{ Totals } \\
\hline & $\begin{array}{l}\text { Mea sured } \\
\quad(\mathrm{ppm})\end{array}$ & $\begin{array}{l}\text { Predicted } \\
\quad(\mathrm{ppm})\end{array}$ & $\begin{array}{c}\text { Error } \\
(\%)\end{array}$ & $\begin{array}{l}\text { Measured } \\
\quad(\mathrm{ppm})\end{array}$ & $\begin{array}{l}\text { Predicted } \\
\quad(\mathrm{ppm})\end{array}$ & $\begin{array}{l}\text { Error } \\
(\%)\end{array}$ & $\begin{array}{l}\text { Mea sured } \\
(\mathrm{ppm})\end{array}$ & $\begin{array}{l}\text { Predicted } \\
\quad(\mathrm{ppm})\end{array}$ & $\begin{array}{c}\text { Error } \\
(\%)\end{array}$ \\
\hline $\begin{array}{l}1 \\
2 \\
3 \\
4 \\
\text { Sund- } \\
\text { st rand/ } \\
\text { NASA }\end{array}$ & $\begin{array}{l}76.3 \\
93.4 \\
194.9 \\
216.8 \\
677.4\end{array}$ & $\begin{array}{r}57.5 \\
79.7 \\
186.9 \\
247.5 \\
668.5\end{array}$ & $\begin{array}{r}-25 \\
-15 \\
-4 \\
+14 \\
-1\end{array}$ & $\begin{array}{c}0 \\
12.0 \\
33.1 \\
29.2 \\
538.5\end{array}$ & $\begin{array}{r}8.4 \\
0.3 \\
10.6 \\
37.2 \\
538.3\end{array}$ & $\begin{array}{r}- \\
-98 \\
-68 \\
+27 \\
<1\end{array}$ & $\begin{array}{r}76.3 \\
105.4 \\
228.0 \\
246.0 \\
1212.9\end{array}$ & $\begin{array}{r}65.9 \\
80.0 \\
197.5 \\
284.7 \\
1206.8\end{array}$ & $\begin{array}{r}-14 \\
-24 \\
-13 \\
+16 \\
<1\end{array}$ \\
\hline
\end{tabular}




\section{CONCLUSIONS AND RECOMMENDATIONS}

this report:

The following important conclusions can be drawn from the results presented in

1. A method of predicting degradation in ORC systems using toluene as the working fluid has been developed.

2. Air must be strictly excluded from any ORC system using toluene as a working fluid.

3. Provided that the toluene does not come in contact with oxygen, it is a very stable fluid at high temperatures.

4. Degradation products have been identified, and none is expected to cause serious problems in an ORC system.

5. Some impurities in toluene showed very little degradation in these experiments and could be potential ORC working fluids themselves.

The computer program shown in App. E can be used to predict degradation in ORC systems. With the constants $R_{\mathrm{O}}=9.9917 \times 10^{9} \mathrm{ppm} / \mathrm{h}$ and $\mathrm{K}=23,056^{\circ} \mathrm{R}$ in line 50010 , the program gives good accuracy up to about $680^{\circ} \mathrm{F}$, where a single chemical reaction resulting in formation of bibenzyl is dominant.* The input data required by the program are simple, and the program requires only about five seconds of running time on a personal computer. By performing repeated runs of the computer program for each major chemical reaction with the constants $R_{o}$ and $K$ adjusted accordingly, then summing the degradations attributable to each chemical reaction, the temperature range of the program can be extended. Using $R_{o}=3.6442 \times 10^{11} \mathrm{ppm} / \mathrm{h}$ and $\mathrm{K}=27,163^{\circ} \mathrm{R}$ for the methyl-group activation reaction (Eq. 5.2) and $R_{o}=3.9485 \times 10^{30} \mathrm{ppm} / \mathrm{h}$ and $\mathrm{K}=$ $79,215^{\circ} \mathrm{R}$ for the ring-carbon activation reaction (Eq. 5.4), the temperature range of the program can be extended at least to $750^{\circ} \mathrm{F}$. Measured and predicted degradations for this two-activation-equation model are shown in Table 5.8.

Oxygen reacts almost immediately with toluene to form benzaldehyde in an ORC system. The sources of oxygen for the reaction are (1) air leakage into the system, (2) residual air not completely purged from the system before the toluene is loaded, (3) dissolved air in the toluene, and (4) oxygen-bearing impurities in the toluene. Therefore, it is imperative to design the ORC system so air cannot enter during operation or shutdown. We also recommend degassing the toluene before an ORC system is operated at temperature. This might be accomplished in the field by evacuating the system after loading the toluene or after a long period of shutdown and allowing some of the toluene to boil off along with the dissolved air.

\footnotetext{
*Because the computer program cannot include subscript symbols, the constant denoted by " $R_{0}$ " in the text is represented by "R0" in the program.
} 
Toluene appears to be stable to at least $750^{\circ} \mathrm{F}$, according to results from both the Sundstrand/NASA experiment and our own. If Sundstrand's result is extrapolated, the total degradation after one year of continuous operation would be less than $0.5 \%$ in their loop. (The actual degradation rate would decrease if the fluid inventory were increased.) If there were no temperature excursions, an ORC system could operate for several years at $750^{\circ} \mathrm{F}$ before a fluid change would become necessary.

In the absence of oxygen, no degradation products that would threaten the integrity of the system, such as strong acids, are formed. If there is more oxygen present than was the case in our tests, there is a potential for oxidizing the benzaldehyde into benzoic acid, but this is a relatively mild acid. The major liquid-phase degradation products are bibenzyl and, at higher temperatures, C2-biphenyl and C1-fluorene. Because these compounds are less volatile than toluene, they will have a tendency to collect in the evaporator and foul it. We recommend that evaporator fouling be investigated in the future.

Noncondensable degradation products are mainly hydrogen and methane, although some light alkanes and alkenes were found. All of these gases tend to accumulate in the condenser and blanket it, thus reducing its effective heat-transfer coefficient. In our tests, we observed that the coolant flow to the condenser had to be increased gradually during the experiment as noncondensable products accumulated. We recommend that ORC systems include a cold trap in their design to periodically or continuously remove noncondensable gases.

Some of the impurities in toluene, such as cyclopentanes and cyclohexanes, appear to be very stable themselves. Cyclohexane -- with a molecular weight of 84.16, a boiling point of $178.5^{\circ} \mathrm{F}$, a critical temperature of $538^{\circ} \mathrm{F}$, and a critical pressure of 59.6 psia -- might be useful for supercritical cycles. We recommend investigation of cyclopentanes and cyclohexanes (with or without added methyl or ethyl groups) as potential ORC fluids. 


\section{REFERENCES}

1. Miller, D.R., et al., Optimum Working Fluids for Automotive Rankine Engines, APTD-1563, APTD-1564, APTD-1565, and APTD-1566, Vols. I-IV (1973).

2. Marciniak, T.J., et al., Comparison of Rankine Cycle Power Systems: Effects of Seven Working Fluids, Argonne National Laboratory Report ANL/CNSV-TM-87 (June 1981).

3. Curran, H.M., et al., Assessment of Rankine Cycle for Potential Applications to Solar Powered Cooling of Buildings, ASME Paper No. 74-WA/Sol-74, American Society of Mechanical Engineers, New York (1974).

4. Adam, A.W., and J. Monahan, 100-kW Organic Rankine Cycle Total Energy System, Paper No. 739045 in Proc. Intersociety Energy Conversion Engineering Conf., p. 126 (Aug. 1973).

5. McKenna, R., R. Niggemann, and P. Thollot, Solar Dynamic Power for Space Station, SAE Paper No. 841524, Society of Automotive Engineers (1984).

6. Monahan, J., and R. McKenna, Development of a 1-kW Organic Rankine Cycle Power Plant for Remote Applications, Paper No. 769199 in Proc. Intersociety Energy Conversion Engineering Conf., p. 1148 (1976).

7. Curran, H.M., The Use of Organic Working Fluids in Rankine Engines, Hittman Associates, Columbia, Md., U.S. Department of Energy Report DOE/CS/30202-T1 (Sept. 1979).

8. Curran, H.M., The Use of Organic Working Fluids in Rankine Engines, Paper No. 809194 in Proc. Intersociety Energy Conversion Engineering Conf., p. 985 (Aug. 1980).

9. Luchter, S., and R.A. Renner, An Assessment of the Technology of Rankine Engines for Automobiles, U.S. Department of Energy Report DOE/CS-0125 (formerly U.S. Energy Research and Development Administration Report ERDA-77-54) (1977, reprinted in 1979).

10. Berger, R., Analysis and Reduction of Degradation of Working Fluid in the Sundstrand Organic Rankine Cycle System, Vol. I, Report No. EGG-2265, Sundstrand Energy Systems (July 1983).

11. Boda, F.P., The SCSE Organic Rankine Engine, Paper No. 819610 in Proc. Intersociety Energy Conversion Engineering Conf., pp. 1371-1374 (1981).

12. Miller, D.R., Rankine Cycle Working Fluids for Solar-to-Electrical Energy Conversion, Sandia National Laboratories Report SLA-74-0132, p. 5 (Jan. 1974). 


$$
65 / 66
$$

13. Khalifa, H.E., and B.W. Rhodes, Analysis of Power Cycles for Geothermal Wellhead Conversion Systems, Electric Power Research Institute Report EPRI-AP-4070, Palo Alto, Calif. (June 1985).

14. Abramowitz, M., and I. Stegun, Section 5, Exponential integral and related functions, in Handbook of Mathematical Functions, National Bureau of Standards (1970).

15. Ragaller, D., Sundstrand Aviation Operations, personal communication (1986). 

APPENDIX A:

DAILY AVERAGES, MINIMA, AND MAXIMA OF EVAPORATOR TEMPERATURE, EVAPORATOR PRESSURE, AND CONDENSER PRESSURE 



\section{APPENDIX A: \\ DAILY AVERAGES, MINIMA, AND MAXIMA OF EVAPORATOR TEMPERATURE, EVAPORATOR PRESSURE, AND CONDENSER PRESSURE}

The data provided in this appendix are 24-hour averages, minima, and maxima of the evaporator temperature, evaporator pressure, and condenser pressure compiled from data taken each half hour during the test runs. The purpose of the data provided herein is to verify the accuracy with which the loop parameters were maintained. Since the evaporator temperature and pressure affect the temperature distribution in the hot parts of the loop, they are the most important indicators of how well the loop is controlled. Condenser pressure is included because, if it becomes subatmospheric, air could leak into the loop. Any oxygen in the loop reacts immediately with toluene to form benzaldehyde, a degradation product. 
TABLE A.1 Daily Average, Minimum, and Maximum Pressures and Temperatures for Test Run No. $1\left(635^{\circ} \mathrm{F}\right)$

\begin{tabular}{|c|c|c|c|c|c|c|c|c|c|}
\hline \multirow{2}{*}{$\begin{array}{l}\text { Interval } \\
\quad(\mathrm{h})\end{array}$} & \multicolumn{3}{|c|}{ Temperature $\left({ }^{\circ} \mathrm{F}\right)$} & \multicolumn{3}{|c|}{$\begin{array}{c}\text { Evaporator } \\
\text { Pressure (psia) }\end{array}$} & \multicolumn{3}{|c|}{$\begin{array}{c}\text { Condenser } \\
\text { Pressure (psia) }\end{array}$} \\
\hline & Avg. & Min. & $\operatorname{Max}$. & Avg. & Min. & Max. & Avg. & Min. & Max. \\
\hline $\begin{array}{l}0-24 \\
24-48 \\
48-72 \\
72-96 \\
96-120 \\
120-144 \\
144-168 \\
168-192 \\
192-216 \\
216-240 \\
240-264 \\
264-288 \\
288-312 \\
312-336 \\
336-360 \\
360-384 \\
384-408 \\
408-432 \\
432-456 \\
456-480 \\
480-482^{\mathrm{a}} \\
482-484^{\mathrm{b}} \\
484-507 \\
507-531 \\
531-555 \\
555-579 \\
579-603^{\mathrm{c}} \\
603-627 \\
627-651^{\mathrm{d}} \\
651-675 \\
675-699 \\
699-723 \\
723-747 \\
747-771 \\
771-795 \\
795-819 \\
819-840\end{array}$ & $\begin{array}{l}636.1 \\
637.5 \\
631.4 \\
630.3 \\
630.0 \\
627.5 \\
627.5 \\
633.9 \\
634.8 \\
636.1 \\
635.8 \\
636.4 \\
637.5 \\
637.2 \\
635.8 \\
635.9 \\
637.3 \\
638.6 \\
635.4 \\
636.7 \\
637.3 \\
631.7 \\
636.8 \\
637.0 \\
633.7 \\
634.7 \\
635.0 \\
638.4 \\
637.9 \\
637.3 \\
636.8 \\
635.3 \\
637.9 \\
636.5 \\
635.9 \\
634.8 \\
635.6\end{array}$ & $\begin{array}{l}631.4 \\
635.0 \\
627.7 \\
626.3 \\
625.5 \\
625.9 \\
625.2 \\
631.7 \\
632.6 \\
633.3 \\
633.1 \\
634.5 \\
636.1 \\
633.3 \\
634.2 \\
633.7 \\
635.4 \\
636.8 \\
632.8 \\
635.6 \\
636.8 \\
627.4 \\
630.0 \\
633.7 \\
631.7 \\
633.6 \\
633.4 \\
636.4 \\
636.1 \\
635.1 \\
634.0 \\
633.4 \\
636.1 \\
635.4 \\
633.7 \\
633.3 \\
633.9\end{array}$ & $\begin{array}{l}639.8 \\
638.6 \\
638.6 \\
633.6 \\
635.0 \\
629.7 \\
633.9 \\
637.2 \\
636.7 \\
652.3 \\
637.6 \\
637.9 \\
639.5 \\
639.6 \\
637.9 \\
638.1 \\
640.0 \\
640.7 \\
639.2 \\
637.9 \\
637.8 \\
635.4 \\
639.8 \\
638.9 \\
635.8 \\
636.8 \\
636.8 \\
640.0 \\
640.0 \\
639.5 \\
640.4 \\
638.2 \\
651.6 \\
637.9 \\
637.8 \\
636.8 \\
636.8\end{array}$ & $\begin{array}{l}160.06 \\
160.26 \\
159.94 \\
158.90 \\
160.20 \\
161.70 \\
161.80 \\
159.20 \\
159.54 \\
159.59 \\
159.35 \\
160.36 \\
161.37 \\
161.23 \\
158.75 \\
159.10 \\
159.11 \\
158.89 \\
155.54 \\
151.14 \\
151.50 \\
158.03 \\
160.16 \\
158.51 \\
158.12 \\
157.92 \\
158.32 \\
158.24 \\
158.90 \\
158.38 \\
158.17 \\
157.97 \\
157.85 \\
157.58 \\
157.70 \\
158.60 \\
159.52\end{array}$ & $\begin{array}{l}157.50 \\
158.90 \\
158.60 \\
157.50 \\
158.80 \\
160.10 \\
159.70 \\
156.70 \\
158.50 \\
158.90 \\
157.80 \\
158.50 \\
160.40 \\
160.10 \\
157.40 \\
157.80 \\
157.90 \\
158.20 \\
149.70 \\
150.00 \\
150.90 \\
154.60 \\
157.30 \\
157.20 \\
156.90 \\
156.70 \\
157.40 \\
157.20 \\
157.70 \\
157.40 \\
157.30 \\
157.00 \\
156.70 \\
155.70 \\
156.80 \\
156.60 \\
157.50\end{array}$ & $\begin{array}{l}161.60 \\
161.00 \\
161.00 \\
161.10 \\
161.60 \\
163.40 \\
163.30 \\
161.00 \\
160.40 \\
160.40 \\
160.30 \\
161.70 \\
162.10 \\
162.60 \\
161.50 \\
160.50 \\
160.10 \\
160.10 \\
159.30 \\
152.50 \\
151.90 \\
159.90 \\
163.10 \\
159.50 \\
159.30 \\
158.80 \\
159.30 \\
159.50 \\
159.80 \\
160.30 \\
159.40 \\
158.80 \\
158.70 \\
158.90 \\
159.20 \\
159.60 \\
160.60\end{array}$ & $\begin{array}{l}17.56 \\
17.73 \\
16.42 \\
1720 \\
17.36 \\
17.50 \\
17.61 \\
17.42 \\
17.49 \\
17.43 \\
17.38 \\
17.58 \\
17.84 \\
17.86 \\
17.27 \\
17.83 \\
17.79 \\
17.37 \\
17.24 \\
17.34 \\
17.69 \\
17.92 \\
17.50 \\
17.27 \\
17.57 \\
19.01 \\
17.81 \\
17.36 \\
17.06 \\
17.51 \\
17.55 \\
17.47 \\
17.73 \\
16.76 \\
16.52 \\
16.45 \\
16.61\end{array}$ & $\begin{array}{l}17.08 \\
17.34 \\
15.11 \\
16.68 \\
17.19 \\
17.30 \\
17.34 \\
17.14 \\
17.26 \\
17.26 \\
17.10 \\
17.19 \\
17.65 \\
17.54 \\
16.87 \\
17.68 \\
17.27 \\
17.14 \\
17.04 \\
17.05 \\
17.61 \\
16.23 \\
16.59 \\
16.58 \\
17.38 \\
17.54 \\
17.49 \\
16.60 \\
16.74 \\
16.52 \\
17.33 \\
17.17 \\
17.31 \\
16.40 \\
16.36 \\
16.31 \\
15.99\end{array}$ & $\begin{array}{l}17.79 \\
18.03 \\
17.68 \\
17.68 \\
17.56 \\
17.65 \\
18.09 \\
18.01 \\
17.71 \\
17.61 \\
17.66 \\
17.90 \\
18.03 \\
18.09 \\
18.07 \\
18.26 \\
18.39 \\
17.69 \\
17.60 \\
17.59 \\
17.77 \\
19.09 \\
18.19 \\
17.97 \\
17.86 \\
22.48 \\
18.78 \\
18.33 \\
17.998 \\
17.80 \\
17.85 \\
17.83 \\
18.27 \\
18.46 \\
16.71 \\
16.73 \\
16.79\end{array}$ \\
\hline Overall & 635.3 & 625.2 & 652.3 & 158.89 & 149.70 & 163.40 & 17.42 & 15.11 & 22.48 \\
\hline
\end{tabular}

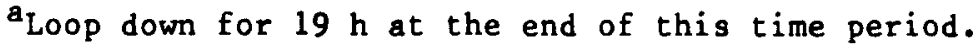

${ }^{b}$ Loop down for $2 \mathrm{~h}$ at the end of this time period.

$c_{1.5} \mathrm{~h}$ of data unavailable in this time period.

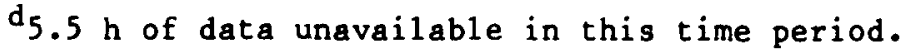


TABLE A.2 Daily Average, Minimum, and Maximum Pressures and Temperatures for Test Run No. $2\left(600^{\circ} \mathrm{F}\right)$

\begin{tabular}{|c|c|c|c|c|c|c|c|c|c|}
\hline \multirow{2}{*}{$\begin{array}{l}\text { Interval } \\
\quad(\mathrm{h})\end{array}$} & \multicolumn{3}{|c|}{ Temperature $\left({ }^{\circ} \mathrm{F}\right)$} & \multicolumn{3}{|c|}{$\begin{array}{c}\text { Evaporator } \\
\text { Pressure (psia) } \\
\end{array}$} & \multicolumn{3}{|c|}{$\begin{array}{c}\text { Condenser } \\
\text { Pressure (psia) }\end{array}$} \\
\hline & Avg. & Min. & Max. & Avg. & Min. & Max. & Avg. & Min. & Max. \\
\hline $0-24$ & 597.4 & 595.2 & 603.5 & 489.93 & 483.70 & 508.10 & 17.35 & 10.94 & 18.66 \\
\hline $24-48$ & 98.7 & 597.7 & 599.4 & 495.59 & 489.70 & 502.90 & 16.83 & 14.04 & 17.16 \\
\hline $48-72$ & 99.0 & 598.4 & 599.6 & 498.77 & 492.30 & 503.20 & 17.31 & 17.04 & 17.57 \\
\hline $72-96^{a}$ & 98.8 & 598.5 & 599.1 & 499.19 & 490.90 & 502.60 & 17.48 & 17.28 & 17.80 \\
\hline $96-120$ & 8.8 & 598.3 & 599.3 & 490.79 & 486.80 & 493.70 & 17.65 & 17.50 & 17.78 \\
\hline $120-144$ & 98.7 & 598.0 & 599.1 & 491.67 & 488.00 & 496.20 & 17.48 & 17.26 & 17.72 \\
\hline $144-168$ & 98.8 & 598.1 & 599.3 & 491.95 & 486.20 & 497.20 & 17.37 & 17.19 & 17.57 \\
\hline $168-192$ & 598.8 & 598.1 & 601.2 & 493.66 & 490.40 & 499.00 & 17.26 & 17.06 & 17.34 \\
\hline $192-$ & 598.7 & 598.2 & 599.1 & 492.76 & 487.20 & 497.70 & 16.98 & 16.75 & 17.14 \\
\hline $216-240$ & 98.5 & 598.0 & 599.1 & 492.47 & 487.40 & 497.20 & 16.83 & 16.70 & 16.92 \\
\hline $240-264$ & 98.4 & 597.9 & 599.1 & 492.65 & 488.90 & 498.10 & 16.79 & 16.73 & 16.86 \\
\hline $264-288$ & 599.8 & 599.1 & 600.5 & 495.97 & 488.00 & 501.80 & 17.04 & 15.02 & 17.52 \\
\hline $288-312$ & 99.4 & 598.7 & 600.3 & 492.98 & 488.00 & 509.80 & 17.16 & 16.78 & 17.43 \\
\hline $312-$ & 99. & 599.2 & 600.2 & 495.36 & 489.10 & 500.80 & 17.31 & 17.20 & 17.40 \\
\hline $336-360$ & 599.6 & 599.1 & 600.3 & 495.82 & 492.30 & 500.10 & 17.27 & 17.10 & 17.37 \\
\hline $360-384$ & 99.7 & 599.1 & 600.2 & 494.91 & 490.80 & 500.30 & 17.16 & 17.04 & 17.26 \\
\hline $384-408$ & 99.7 & 599.1 & 600.3 & 494.74 & 490.70 & 500.70 & 17.15 & 17.00 & 17.26 \\
\hline $408-$ & 599.4 & 598.9 & 600.2 & 488.61 & 450.80 & 499.90 & 17.14 & 17.02 & 17.26 \\
\hline $432-456$ & 600.2 & 599.5 & 600.9 & 499.92 & 490.40 & 505.60 & 16.81 & 15.60 & 17.19 \\
\hline 480 & 0.5 & 600.1 & 601.1 & 493.83 & 488.00 & 500.0 & 17.41 & 14.75 & 18.42 \\
\hline & 0.3 & 599.5 & 601.0 & 493.76 & 489.50 & 498. & & 17.22 & 18.16 \\
\hline & 0.5 & 599.9 & 600 . & 494.55 & 489.70 & 498. & & 17.93 & 18.21 \\
\hline $528-$ & 0.2 & 599.6 & 600.7 & 491.32 & 486.60 & 496.50 & 18.03 & 17.81 & 18.20 \\
\hline $552-576$ & 0.2 & 599.4 & 600.8 & 492.84 & 488.40 & 497.40 & 17.91 & 17.72 & 18.09 \\
\hline $576-600$ & 9.5 & 599.1 & 599.9 & 491.01 & 486.90 & 495.3 & 17.59 & 17.34 & 17.72 \\
\hline $600-$ & 0.1 & 599.5 & 601.0 & 495.02 & 487.30 & 505. & 17.51 & 15.35 & 17.77 \\
\hline 624 & 0.0 & 599.4 & 600.5 & 491.21 & 484.60 & 498.60 & 17.00 & 16.07 & 17.84 \\
\hline $648-t$ & 600.4 & 600.1 & 601.0 & 490.80 & 482.40 & 498.10 & 18.12 & 17.62 & 18.58 \\
\hline & 0.3 & 599.6 & 600.9 & 491.51 & 486.10 & 497.1 & 17.60 & 17.23 & 18.68 \\
\hline $696-7$ & 0.2 & 599.7 & 600.8 & 490.48 & 486.80 & 495.4 & 17.51 & 17.35 & 17.63 \\
\hline $720-7$ & 600.1 & 599.5 & 600.8 & 492.58 & 487.70 & 498.6 & 17.52 & 17.37 & 17.64 \\
\hline & 0.2 & 599.7 & 600.8 & 492.42 & 489.10 & 498.0 & 17. & 17.11 & 17.73 \\
\hline & 600.6 & 599.9 & 601.2 & 493.56 & 488.10 & 499.70 & 17.10 & 15.30 & 17.39 \\
\hline $792-\varepsilon$ & 600.3 & 599.7 & 600.8 & 491.38 & 487.30 & 498.00 & 17.34 & 17.22 & 17.46 \\
\hline & 0.4 & 600.0 & 600.8 & 495.42 & 490.20 & 502. & 17.42 & 17.25 & 17.56 \\
\hline $840-864$ & 600.8 & 600.4 & 601.4 & 499.34 & 494.00 & 503.70 & 17.38 & 17.15 & 17.57 \\
\hline $864-888$ & 600.5 & 599.8 & 601.2 & 499.08 & 494.10 & 503.60 & 16.94 & 16.73 & 17.12 \\
\hline $888-912$ & 600.1 & 599.3 & 600.9 & 499.24 & 495.10 & 503.80 & & 16.45 & 16.84 \\
\hline $912-936$ & 600.1 & 599.7 & 600.5 & 500.17 & 488.20 & 507.00 & 16.56 & 16.31 & 17.13 \\
\hline $936-960$ & 600.0 & 599.4 & 600.6 & 490.30 & 470.50 & 501.70 & 16.63 & 15.82 & 17.09 \\
\hline $960-984$ & 600.0 & 599.5 & 600.6 & 493.10 & 486.70 & 497.70 & 16.77 & 16.67 & 16.92 \\
\hline $984-1006$ & 600.2 & 599.5 & 600.7 & 494.81 & 489.50 & 499.50 & 16.97 & 16.86 & 17.13 \\
\hline Overal1 & 599.7 & 595.2 & 603.5 & 493.89 & 450.80 & 509.80 & 17.26 & 10.94 & 18.68 \\
\hline
\end{tabular}

${ }^{a} 10 \mathrm{~h}$ of data unavailable during this time period. 
TABLE A.3 Daily Average, Minimum and Maximum Pressures and Temperatures for Test Run No. $3\left(650^{\circ} \mathrm{F}\right)$

\begin{tabular}{|c|c|c|c|c|c|c|c|c|c|}
\hline \multirow{2}{*}{$\begin{array}{l}\text { Interval } \\
\quad(\mathrm{h})\end{array}$} & \multicolumn{3}{|c|}{ Temperature $\left({ }^{\circ} \mathrm{F}\right)$} & \multicolumn{3}{|c|}{$\begin{array}{c}\text { Evaporator } \\
\text { Pressure (psia) }\end{array}$} & \multicolumn{3}{|c|}{$\begin{array}{c}\text { Condenser } \\
\text { Pressure (psia) } \\
\end{array}$} \\
\hline & Avg. & Min. & Max. & Avg. & Min. & Max. & Avg. & Min. & Max. \\
\hline $0-24$ & 647.5 & 646.1 & 650.1 & 495.50 & 482.80 & 505.80 & 17.95 & 15.90 & 18.74 \\
\hline $24-48$ & 649.7 & 649.1 & 650.3 & 497.21 & 489.60 & 504.00 & 17.07 & 16.56 & 17.27 \\
\hline $48-72$ & 649.7 & 649.1 & 650.5 & 501.71 & 494.40 & 507.80 & 17.16 & 16.96 & 17.37 \\
\hline $72-96^{a}$ & 649.1 & 648.6 & 649.7 & 505.06 & 499.60 & 515.00 & 17.15 & 16.91 & 17.39 \\
\hline $96-120^{a}$ & 648.6 & 648.0 & 649.9 & 505.71 & 488.30 & 515.80 & 17.28 & 16.12 & 17.89 \\
\hline $120-144$ & 650.0 & 649.3 & 650.7 & 494.18 & 488.10 & 501.80 & 18.21 & 17.50 & 18.63 \\
\hline $144-168$ & 649.8 & 649.2 & 650.6 & 491.23 & 485.30 & 496.70 & 17.55 & 17.31 & 17.92 \\
\hline $168-192$ & 649.8 & 649.0 & 650.5 & 492.91 & 488.80 & 498.50 & 17.91 & 17.62 & 18.12 \\
\hline $192-216$ & 649.8 & 649.1 & 650.5 & 494.85 & 489.90 & 501.40 & 17.90 & 17.52 & 18.10 \\
\hline $216-240$ & 649.1 & 648.1 & 649.8 & 501.51 & 496.60 & 510.40 & 17.99 & 17.62 & 18.18 \\
\hline $240-264$ & 648.9 & 648.5 & 649.3 & 505.78 & 500.80 & 511.00 & 18.04 & 17.86 & 18.22 \\
\hline $264-288^{a}$ & 649.1 & 648.1 & 651.0 & 505.40 & 486.40 & 516.60 & 17.75 & 15.79 & 18.29 \\
\hline $288-312$ & 650.6 & 649.7 & 651.3 & 494.78 & 490.90 & 499.90 & 18.14 & 17.73 & 18.58 \\
\hline $312-336$ & 650.1 & 649.5 & 650.6 & 498.06 & 492.90 & 503.50 & 18.16 & 17.69 & 18.54 \\
\hline $336-360$ & 649.8 & 649.3 & 650.7 & 499.72 & 494.20 & 506.80 & 17.78 & 17.63 & 17.90 \\
\hline $360-384$ & 649.8 & 649.3 & 650.3 & 499.32 & 489.70 & 506.60 & 17.90 & 17.66 & 18.19 \\
\hline $384-408$ & 649.0 & 648.5 & 650.0 & 497.76 & 494.10 & 502.20 & 18.14 & 17.97 & 18.41 \\
\hline $408-432$ & 649.2 & 648.7 & 649.6 & 498.92 & 491.40 & 505.30 & 18.15 & 17.91 & 18.32 \\
\hline $432-456$ & 649.0 & 648.3 & 650.0 & 498.45 & 484.00 & 504.80 & 17.89 & 15.71 & 18.45 \\
\hline $456-480$ & 650.2 & 649.5 & 650.8 & 494.26 & 489.10 & 500.20 & 18.15 & 17.79 & 18.38 \\
\hline $480-504$ & 650.4 & 649.8 & 651.2 & 494.90 & 486.70 & 502.30 & 18.10 & 17.84 & 18.37 \\
\hline $504-528$ & 650.7 & 649.9 & 652.0 & 497.39 & 488.40 & 502.90 & 17.83 & 16.96 & 18.31 \\
\hline-552 & 650.7 & 649.0 & 651.9 & 495.86 & 489.40 & 504.90 & 17.30 & 17.07 & 17.53 \\
\hline $552-576$ & 649.1 & 648.6 & 649.6 & 500.68 & 495.40 & 507.50 & 17.56 & 17.35 & 17.75 \\
\hline $576-600$ & 649.0 & 648.5 & 649.4 & 501.43 & 495.20 & 506.30 & 17.70 & 17.54 & 17.88 \\
\hline $600-624$ & 649.1 & 648.5 & 650.5 & 499.92 & 486.00 & 506.90 & 17.56 & 16.02 & 17.96 \\
\hline 624 & 650.1 & 649.5 & 650. & 497.20 & 493.20 & 502.50 & 18.39 & 17.71 & 18.70 \\
\hline 72 & 650.1 & 649.5 & 650.7 & 496.71 & 491.50 & 501.80 & 18.24 & 17.49 & 18.66 \\
\hline $672-696$ & 650.0 & 649.4 & 650.8 & 495.87 & 490.80 & 500.80 & 17.76 & 17.35 & 17.97 \\
\hline $696-720$ & 650.1 & 649.5 & 650.6 & 496.77 & 491.60 & 502.40 & 17.74 & 17.53 & 17.97 \\
\hline $720-744$ & 650.1 & 649.5 & 650.7 & 496.80 & 493.70 & 502.20 & 17.66 & 17.46 & 17.93 \\
\hline $744-768$ & 649.5 & 648.5 & 650.6 & 503.25 & 494.20 & 509.40 & 17.79 & 17.61 & 17.94 \\
\hline & 649.4 & 648.0 & 649.9 & 502.23 & 486.80 & 512.60 & 17.72 & 15.51 & 18.23 \\
\hline & 650.3 & 649.4 & 650.8 & 496.36 & 489.20 & 501.00 & 18.49 & 17.64 & 18.81 \\
\hline $816-840$ & 650.2 & 649.6 & 650.8 & 493.61 & 485.00 & 500.10 & 18.48 & 17.24 & 19.01 \\
\hline & 650.2 & 649.5 & 650.8 & 497.19 & 489.90 & 501.50 & 17.59 & 17.27 & 17.78 \\
\hline $864-888$ & 650.5 & 649.8 & 650.9 & 494.67 & 489.80 & 500.70 & 17.51 & 17.24 & 17.77 \\
\hline $888-912$ & 650.3 & 649.6 & 651.2 & 492.26 & 486.20 & 497.70 & 17.34 & 17.09 & 17.52 \\
\hline $912-936$ & 650.0 & 649.0 & 650.9 & 498.12 & 491.00 & 505.40 & 17.44 & 17.21 & 17.65 \\
\hline $936-960^{a}$ & 649.5 & 648.8 & 650.4 & 498.90 & 489.30 & 506.60 & 17.37 & 14.73 & 17.93 \\
\hline $960-984$ & 650.2 & 649.6 & 650.7 & 499.07 & 488.40 & 505.70 & 18.16 & 17.44 & 19.01 \\
\hline $984-1006$ & 649.1 & 635.8 & 650.3 & 491.98 & 485.50 & 501.80 & 18.55 & 18.27 & 18.75 \\
\hline Overa11 & 649.7 & 635.8 & 652.0 & 497.94 & 482.80 & 516.60 & 17.82 & 14.73 & 19.01 \\
\hline
\end{tabular}

$a_{0.5} \mathrm{~h}$ of data unavailable in this time period. 
TABLE A.4 Daily Average, Minimum, and Maximum Pressures and Temperatures for Test Run No. $4\left(677^{\circ} \mathrm{F}\right)$

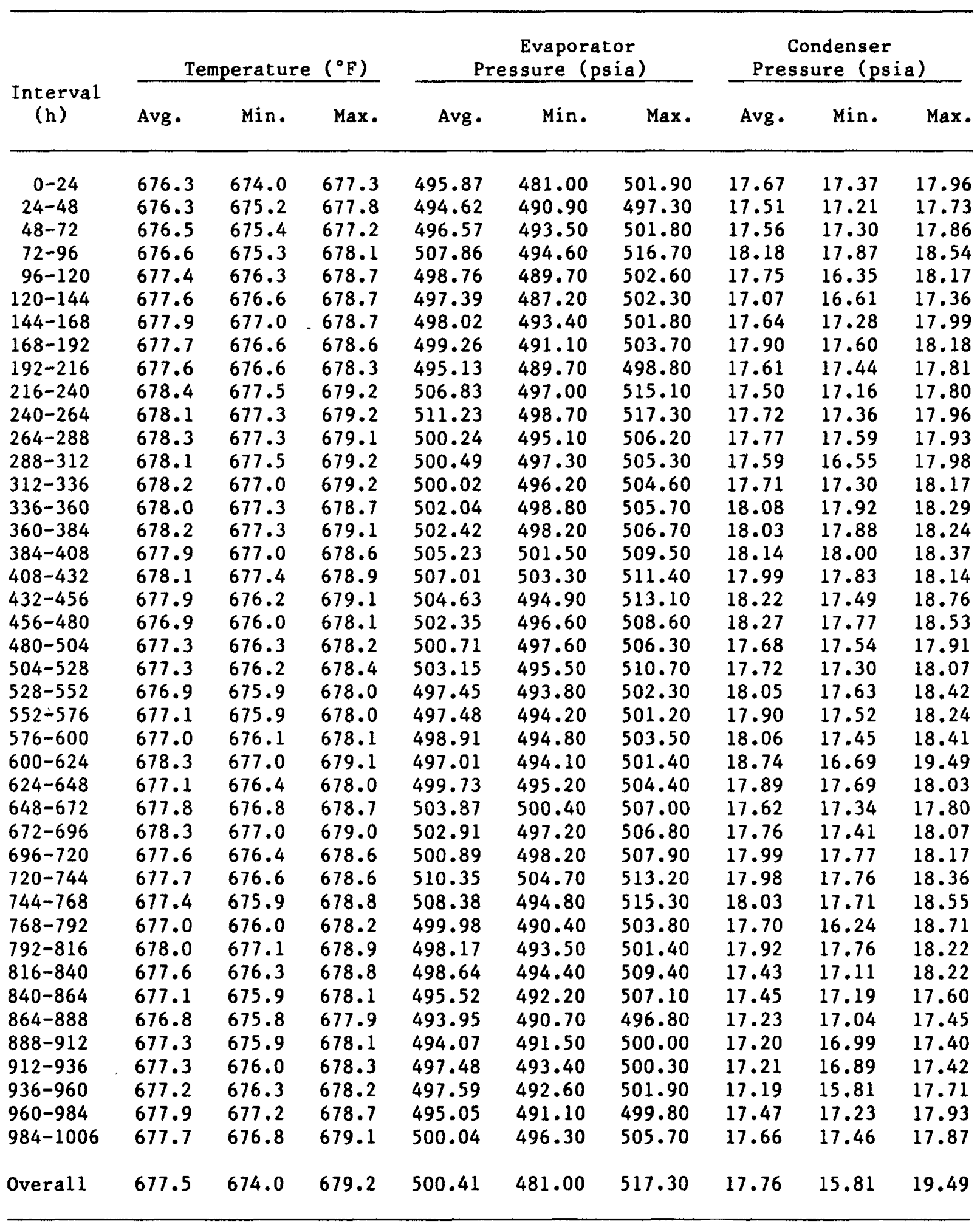


$75 / 76$

APPENDIX B:

IDENTIFICATION OF LIQUID-PHASE IMPURITIES

AND DEGRADATION PRODUCTS 


$$
-
$$




\section{APPENDIX B:}

\section{IDENTIFICATION OF LIQUID-PHASE IMPURITIES}

\section{AND DEGRADATION PRODUCTS}

Figures B.1-B.32 are the ion-chromatograms and mass spectra used to identify liquid-phase impurities in and degradation products of toluene samples obtained in ORC tests. 


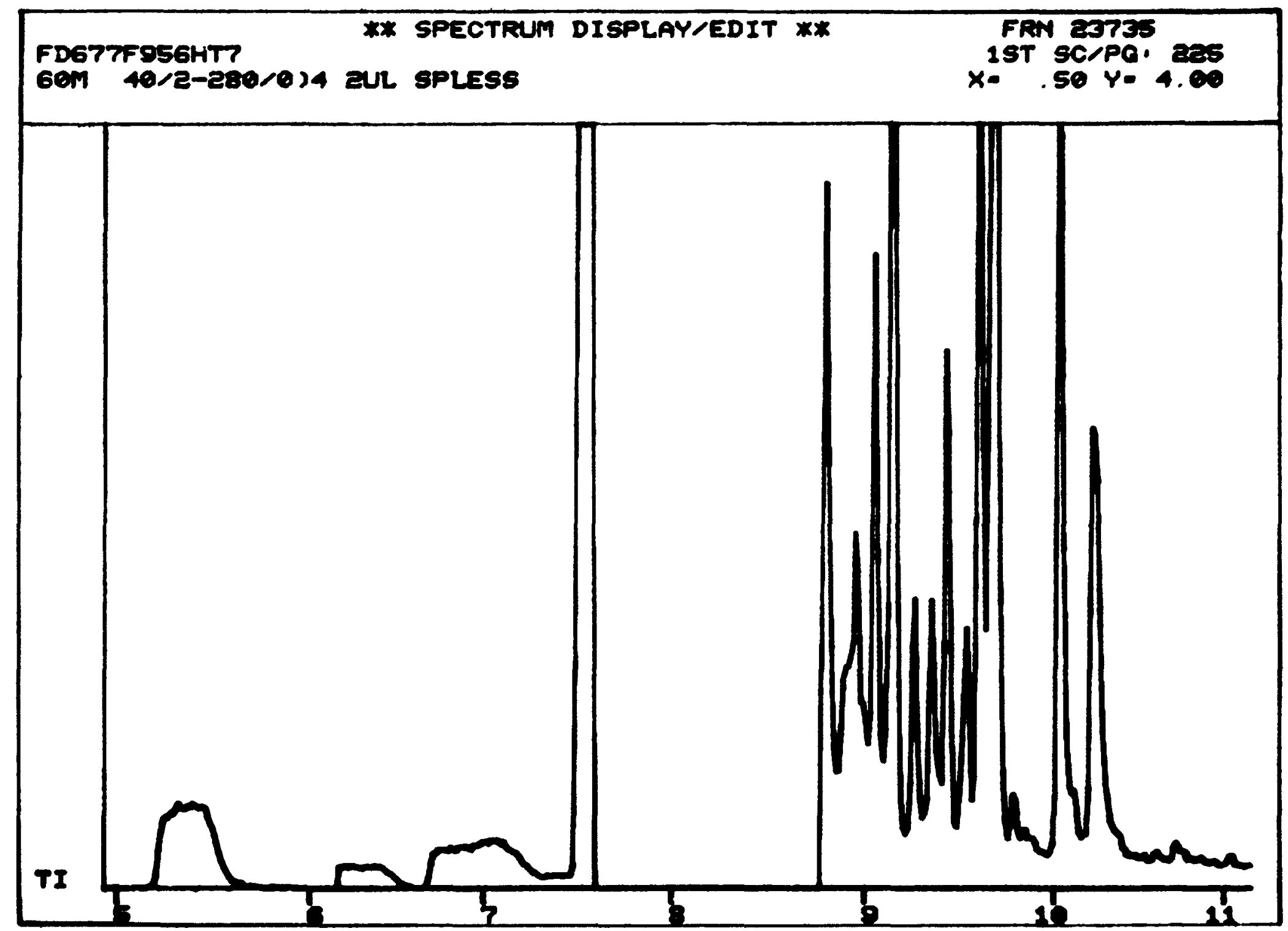

FIGURE B.1 Total Ion Chromatogram Showing 5-11 min of Toluene Degradation for $956 \mathrm{~h} \mathrm{at} 677^{\circ} \mathrm{F}$ 


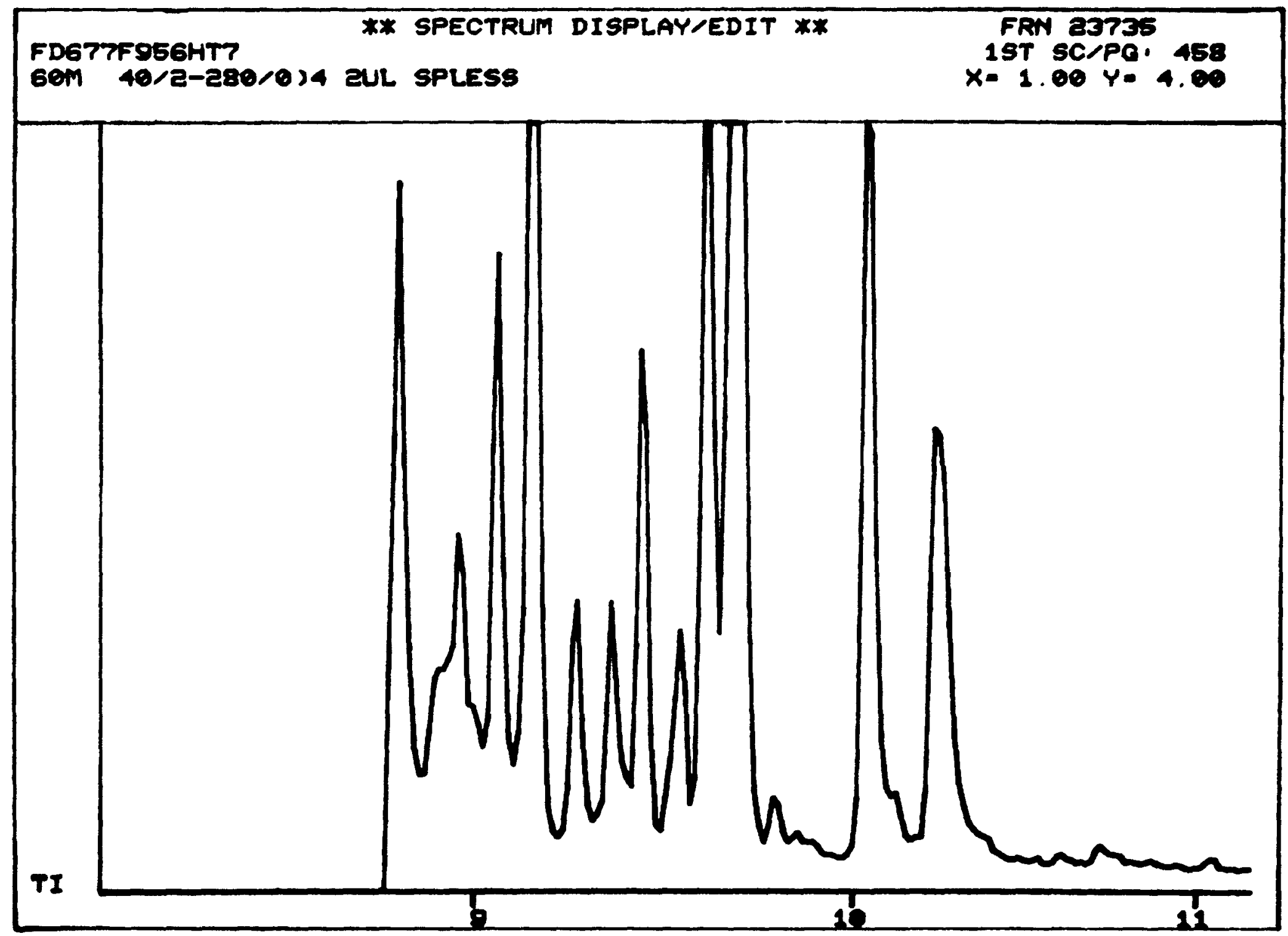

FIGURE B.2 Total Ion Chromatogram Showing 8-11 min of Toluene Degradation for $956 \mathrm{~h}$ at $677^{\circ} \mathrm{F}$ 


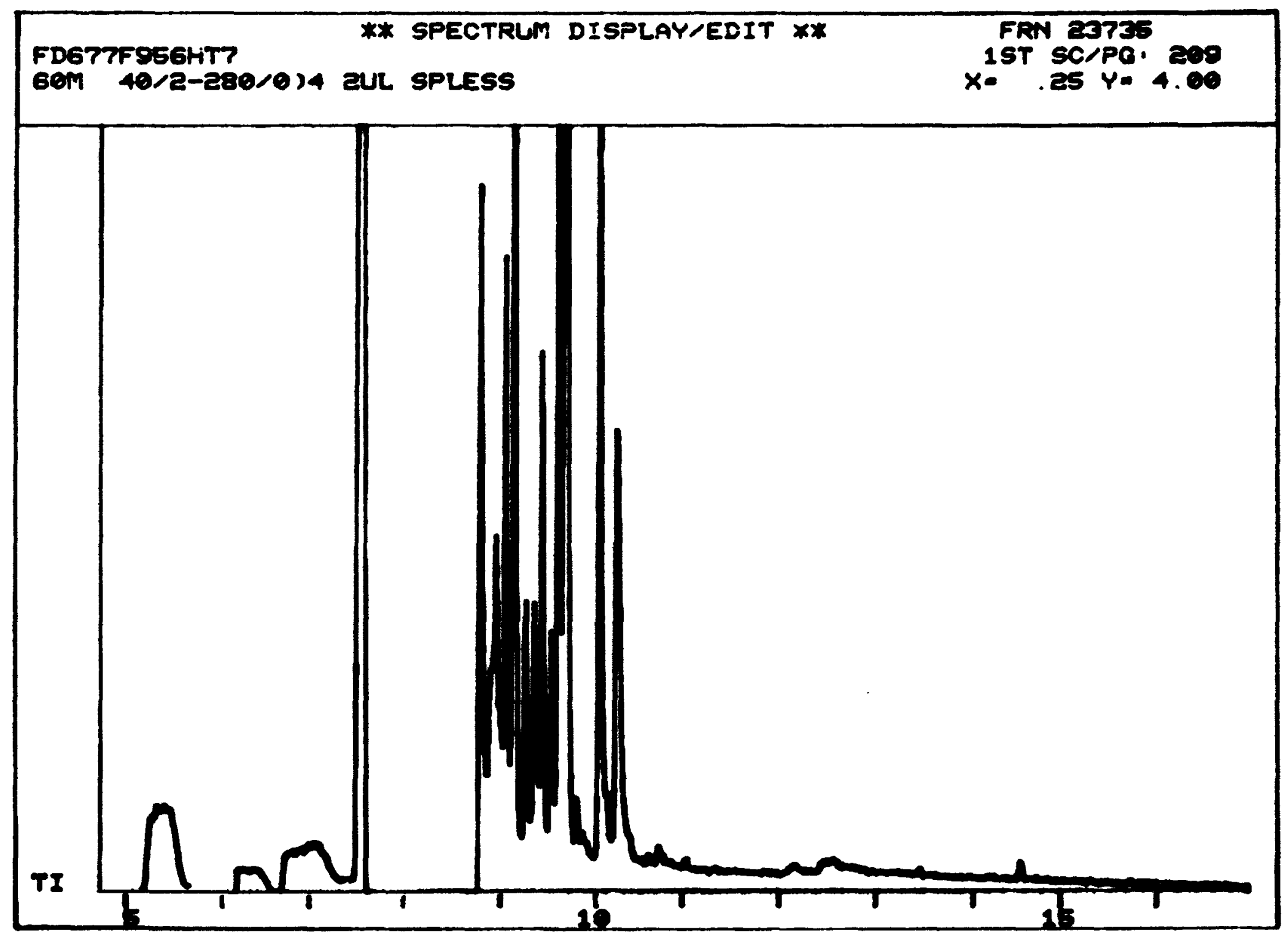

$\infty$

FIGURE B.3 Total Ion Chromatogram Showing 5-17 min of Toluene Degradation for $956 \mathrm{~h}$ at $677^{\circ} \mathrm{F}$ 


$$
I
$$




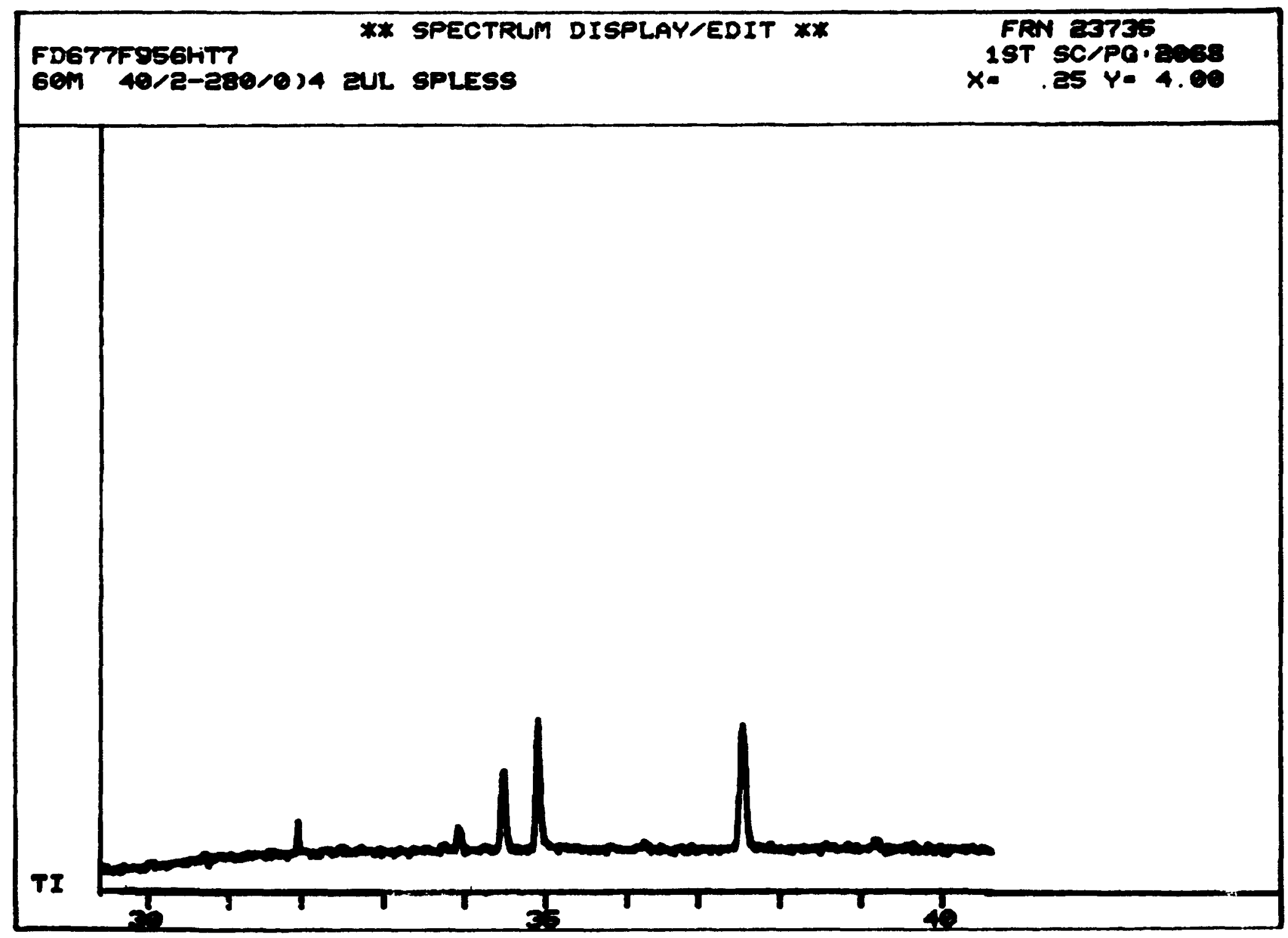

FIGURE B.5 Total Ion Chromatogram Showing 30-40 min of Toluene Degradation for $956 \mathrm{~h}$ at $677^{\circ} \mathrm{F}$ 


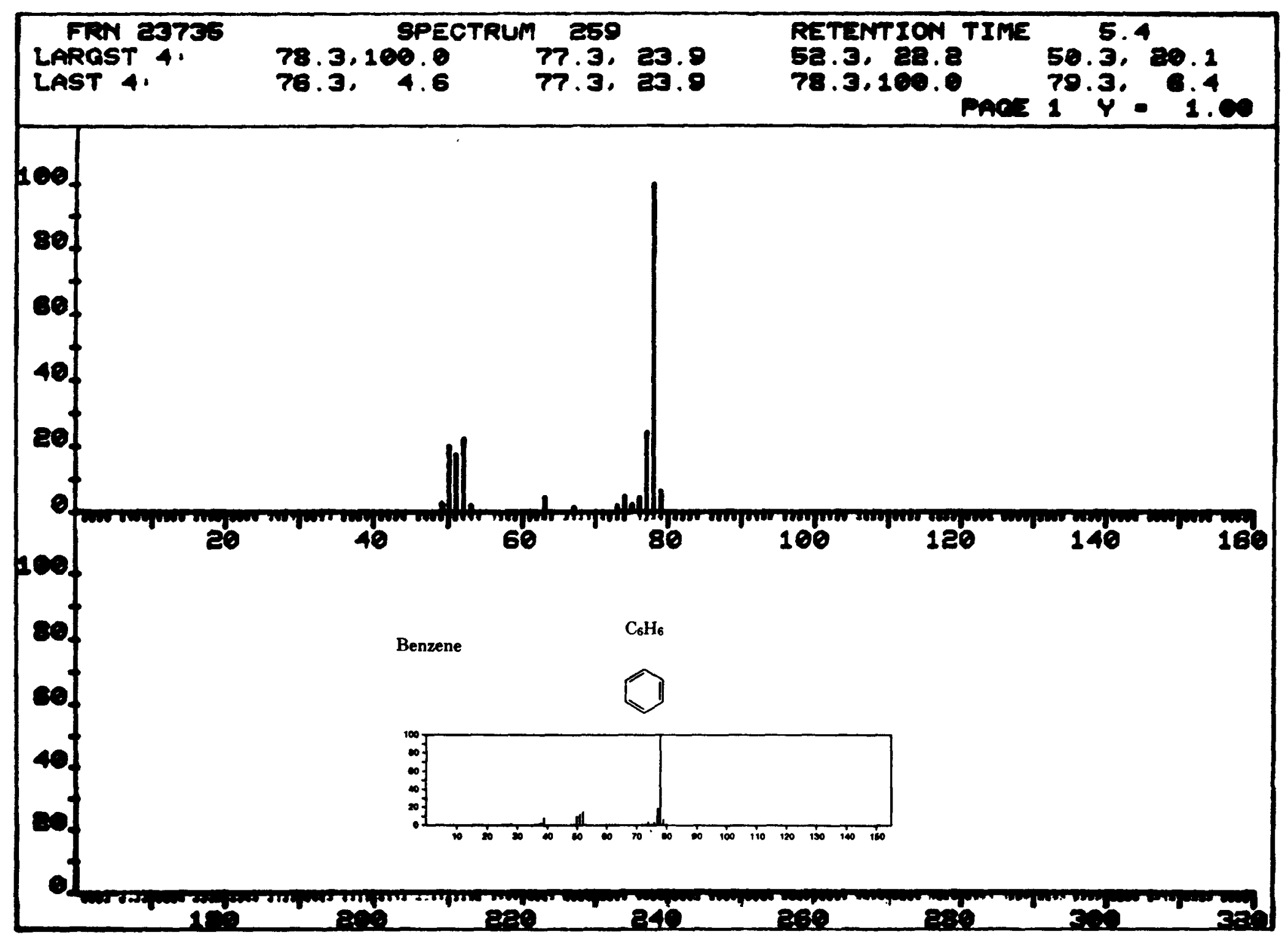

$\stackrel{\infty}{\omega}$

FIGURE B.6 Peak at 5.4 min: Benzene 


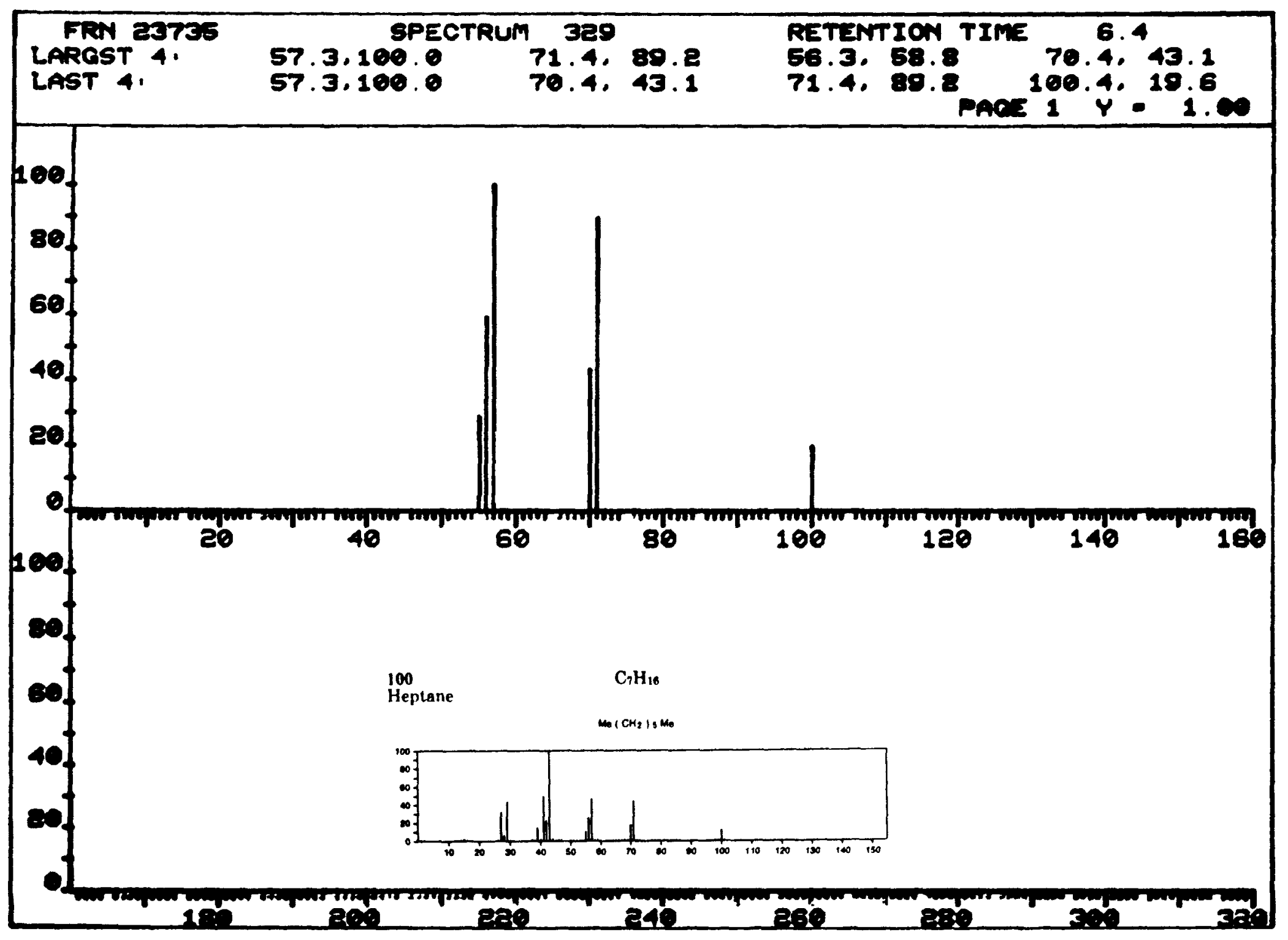

FIGURE B.7 Peak at 6.4 min: Heptane 


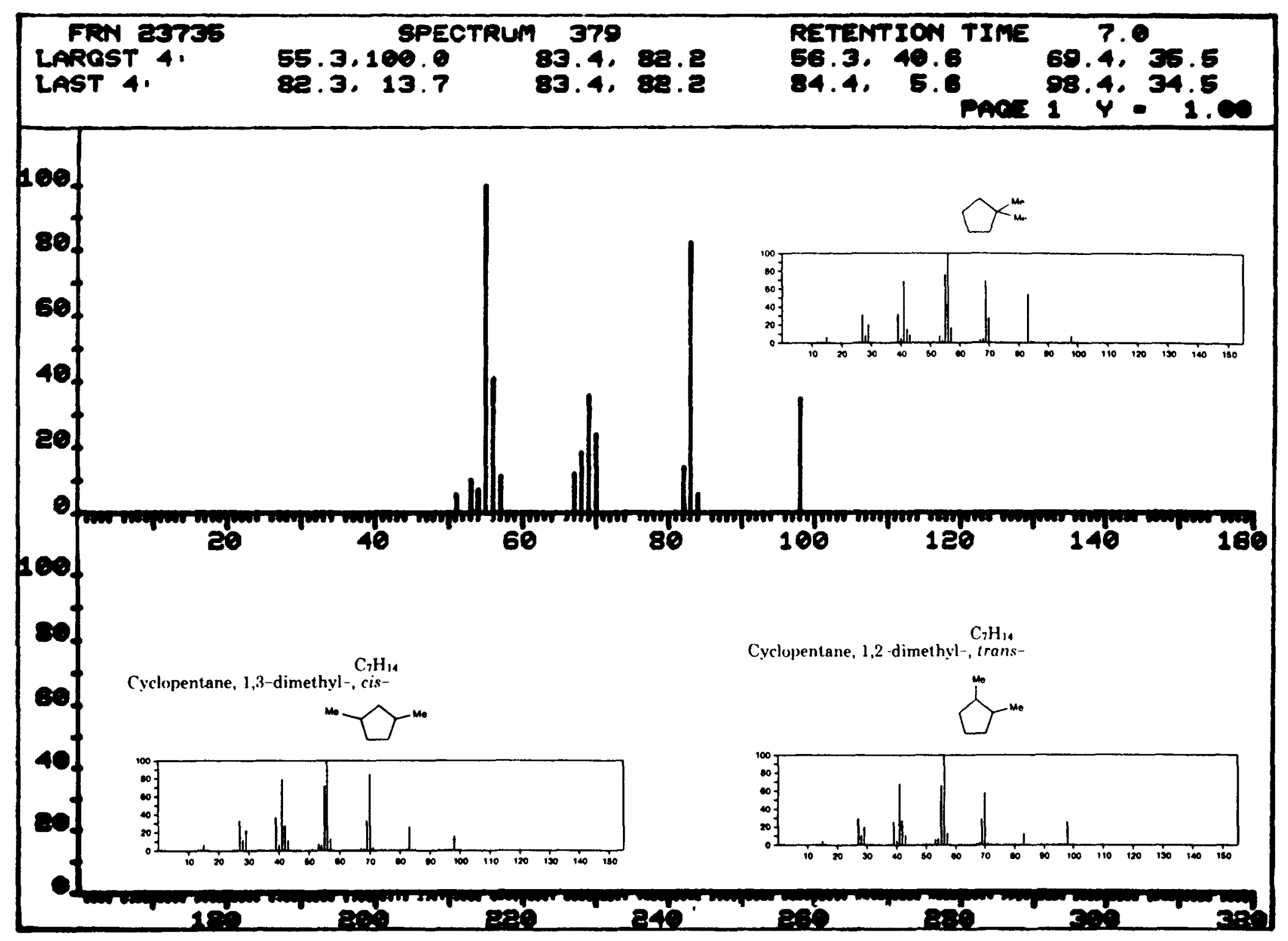

FIGURE B.8 Peak at 7.0 min: Dimethyleyclopentane Isomer 


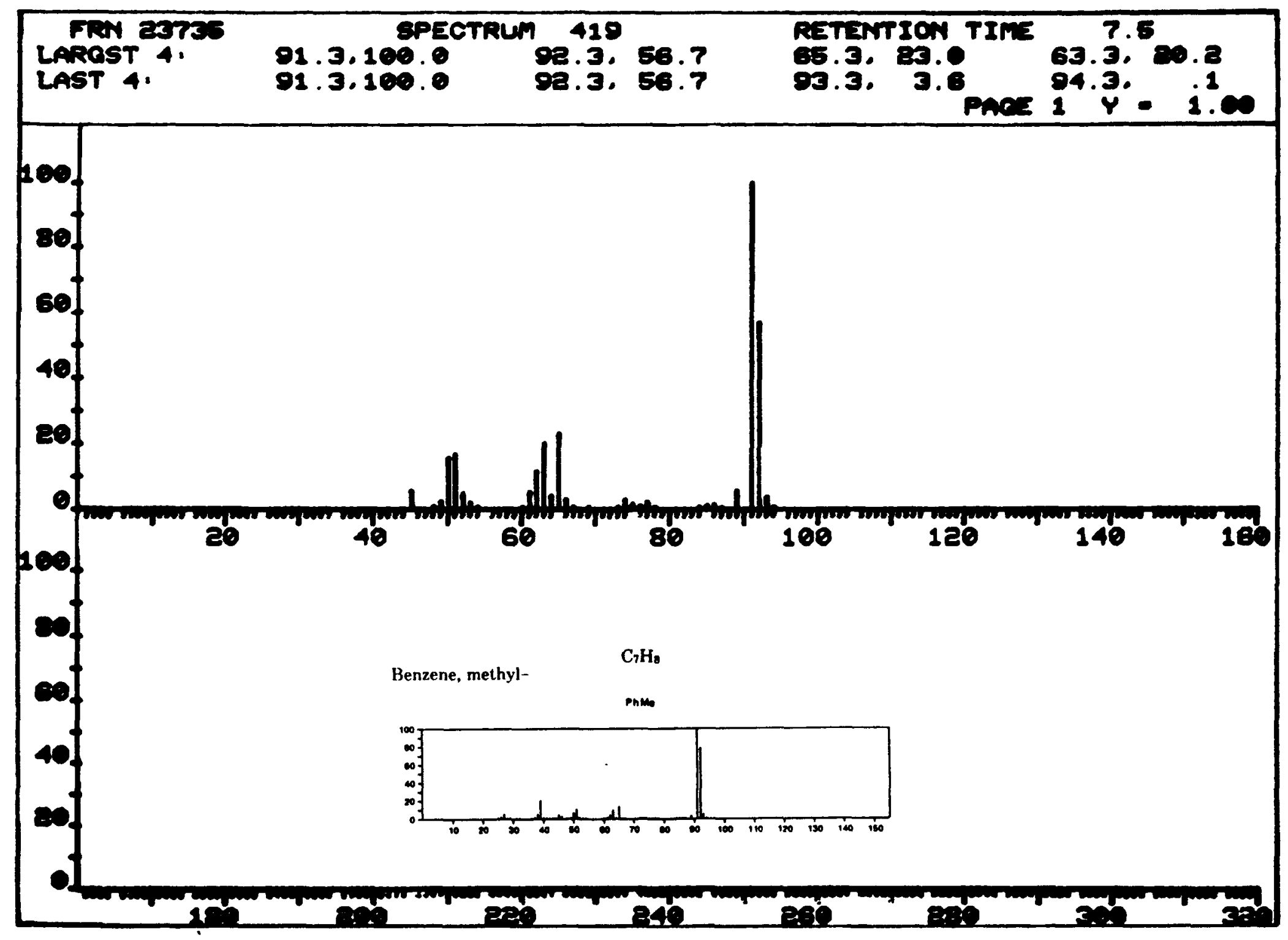

FIGURE B.9 Peak at 7.5 min: Methylbenzene 


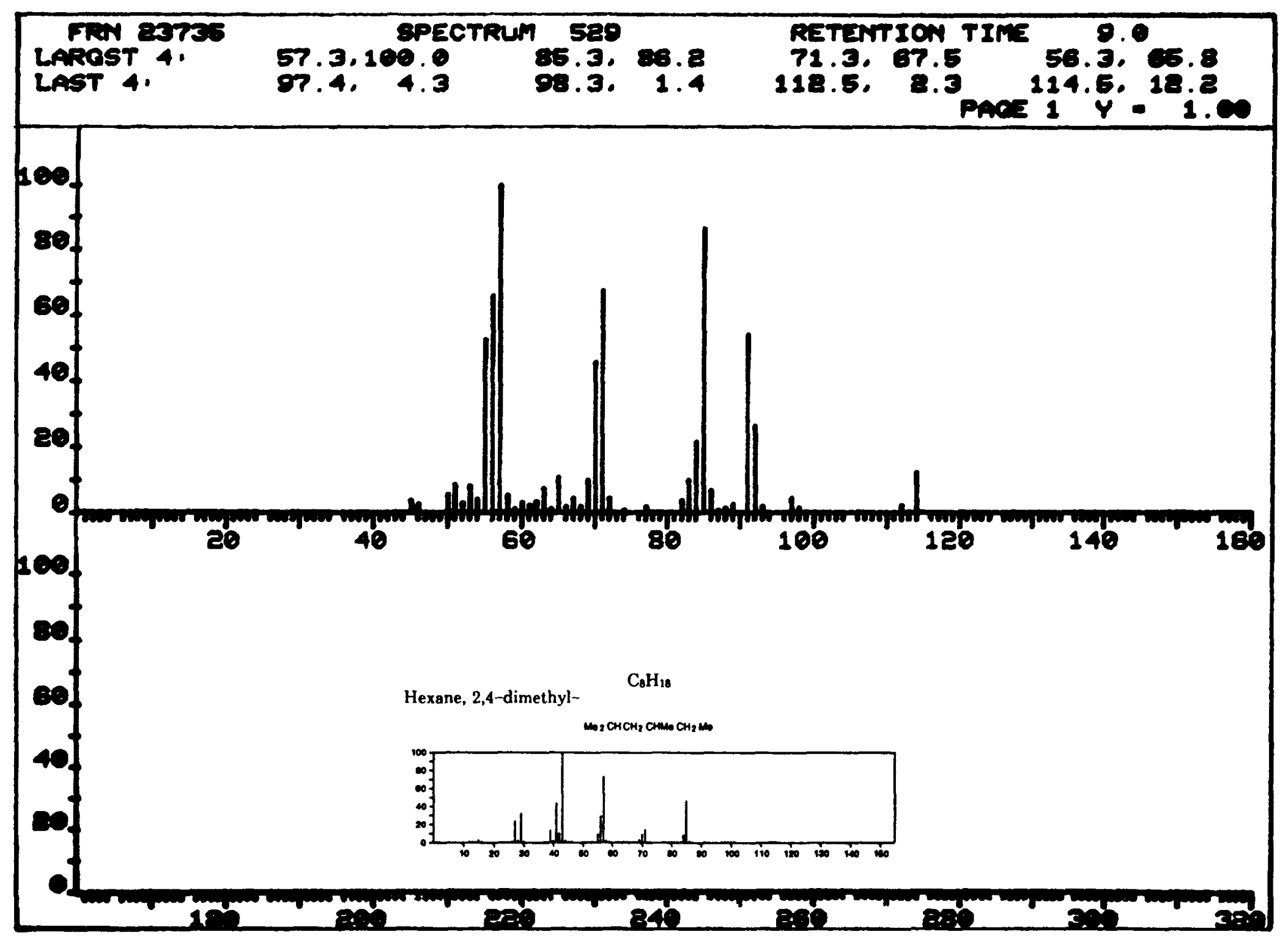

FIGURE B.10 Peak at 9.0 min: Dimethylhexane Isomer 


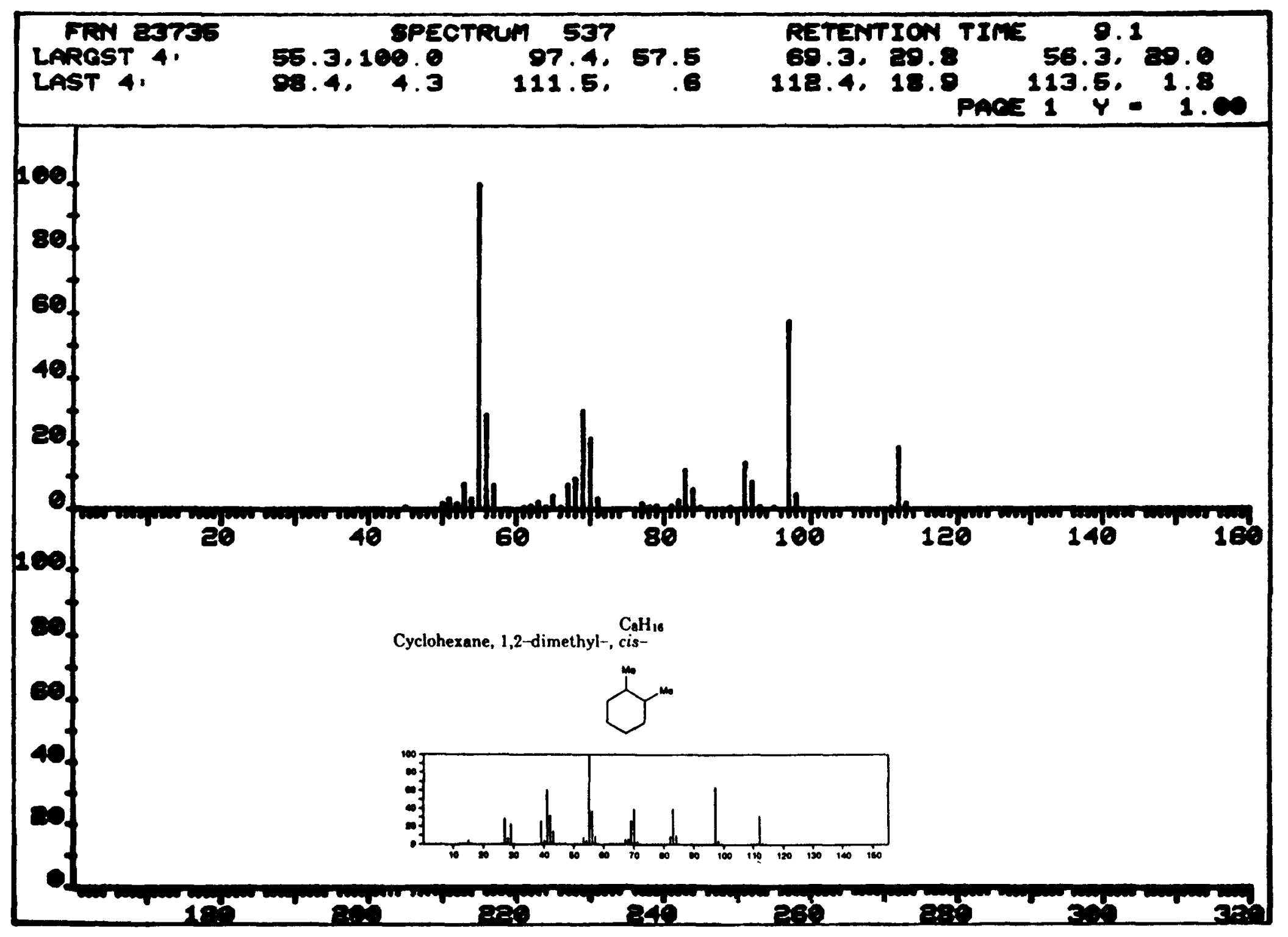

FIGURE B.11 Peak at 9.1 min: Dimethyleyclohexane Isomer 


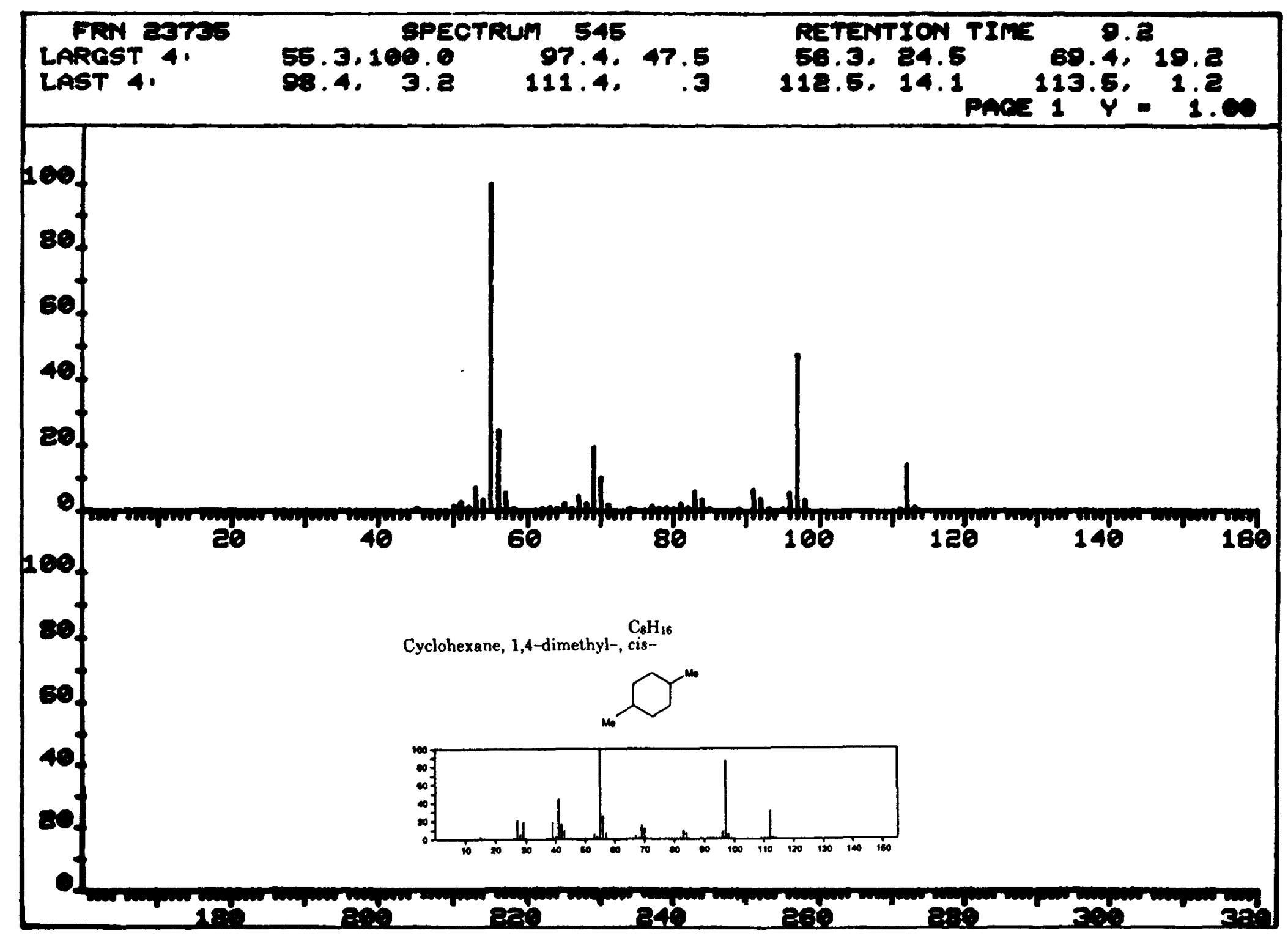

FIGURE B.12 Peak at 9.2 min: Dimethyleyclohexane Isomer 


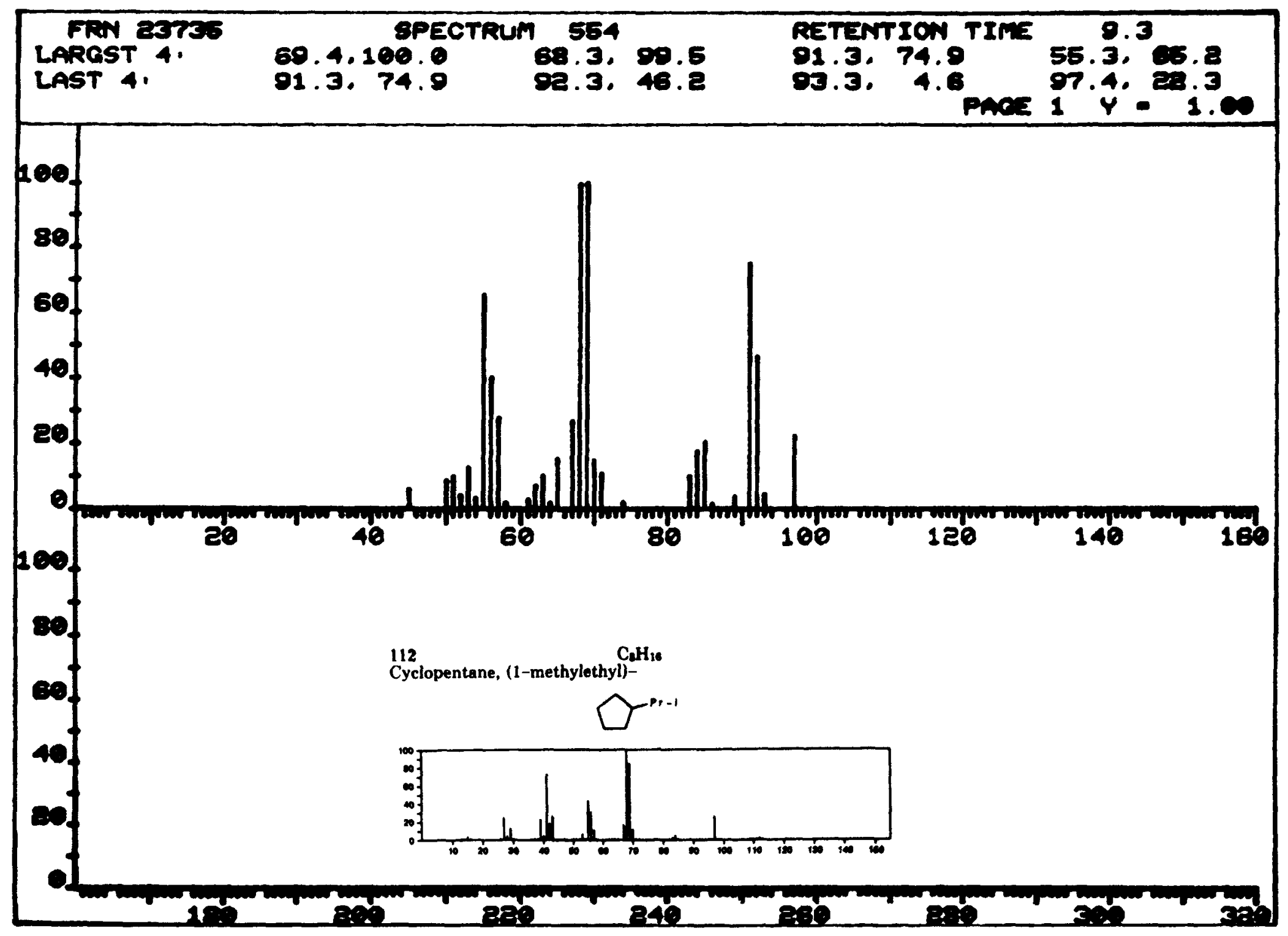

FIGURE B.13 Peak at 9.3 min: A C9 Cycloalkane 


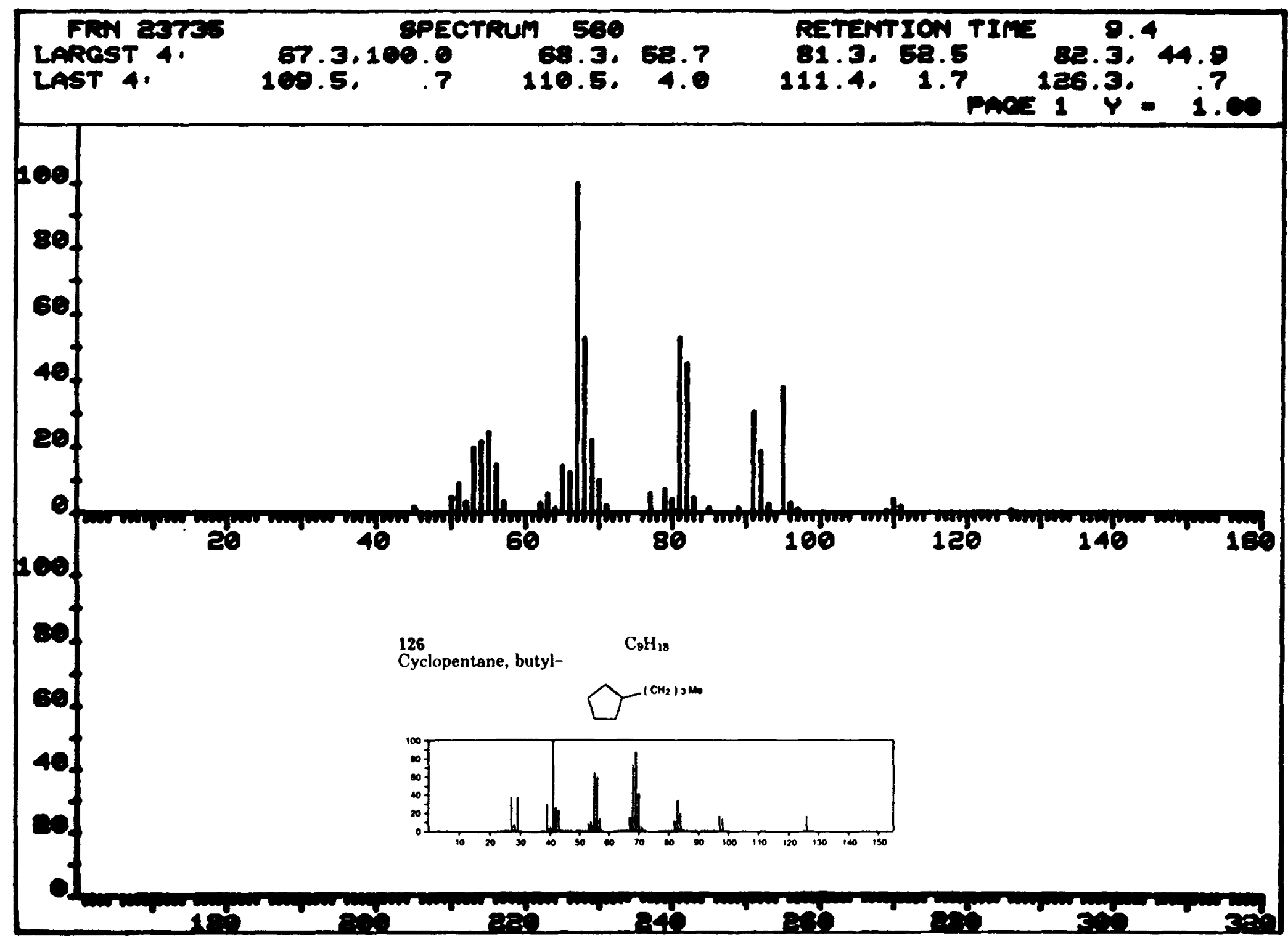

FIGURE B.14 Peak at 9.4 min: A C9 Cycloalkane 


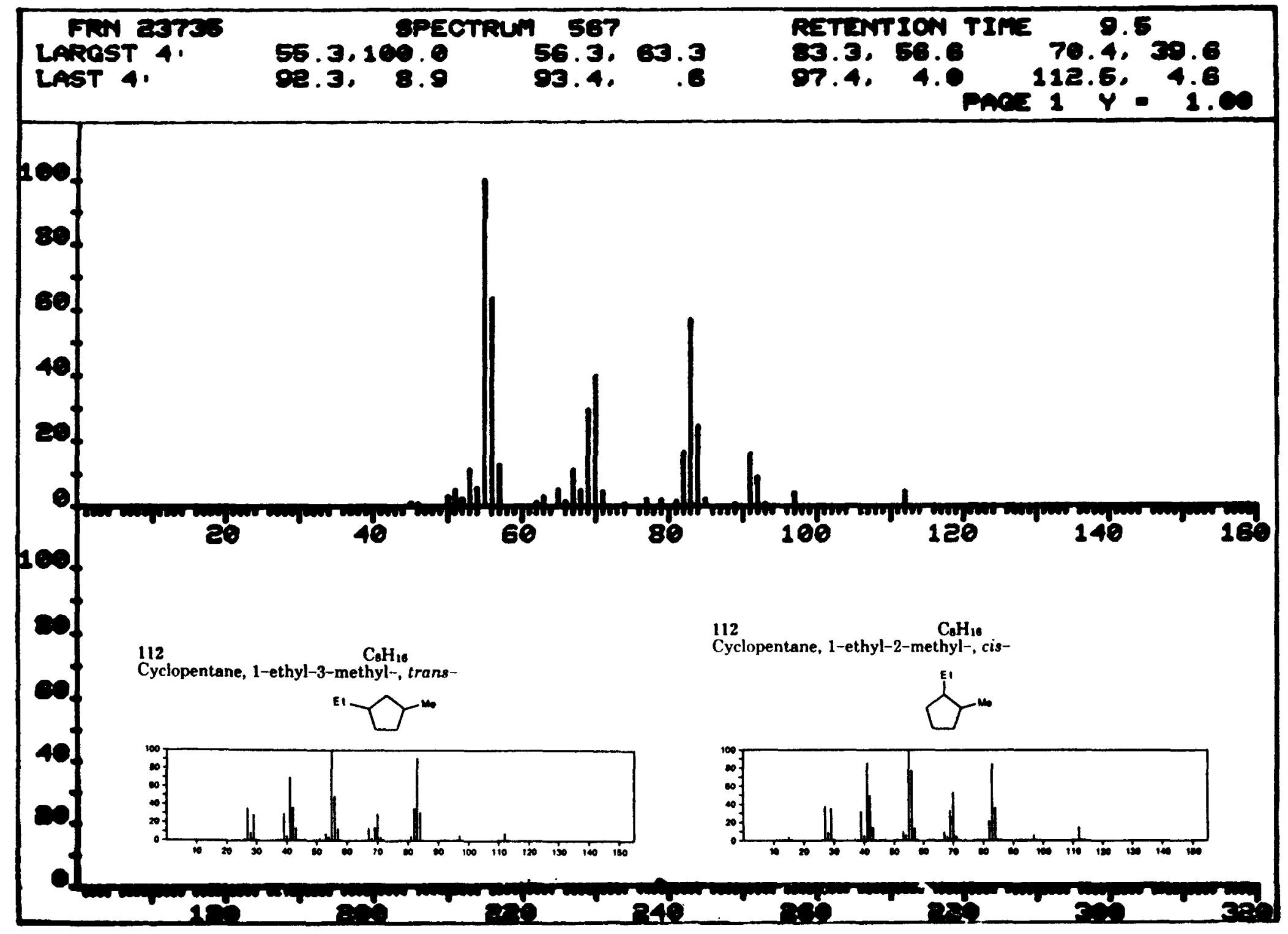

FIGURE B.15 Peak at 9.5 min: A C8 Cycloalkane 


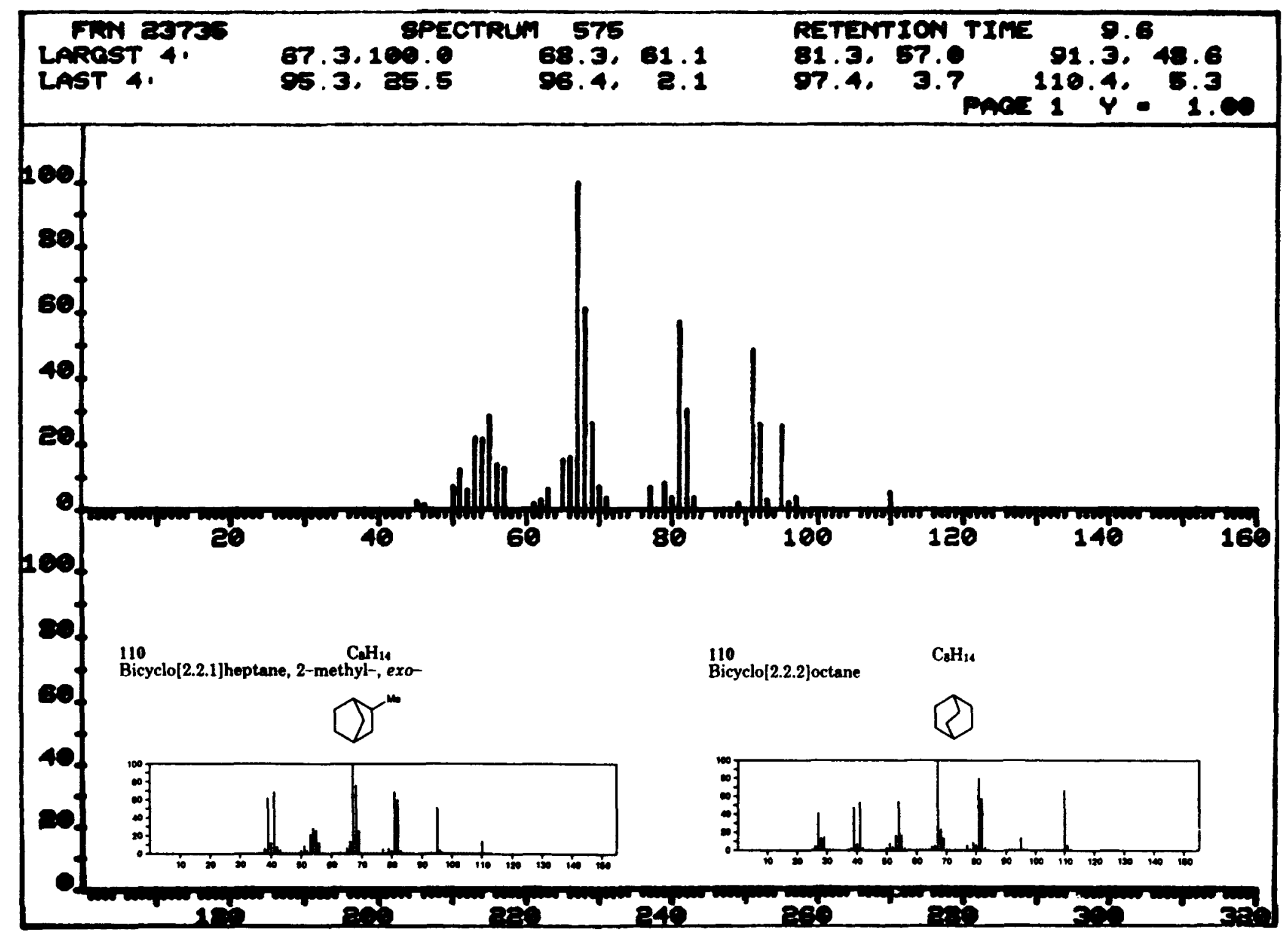

FIGURE B.16 Peak at 9.6 min: A C8 Cycloalkane 


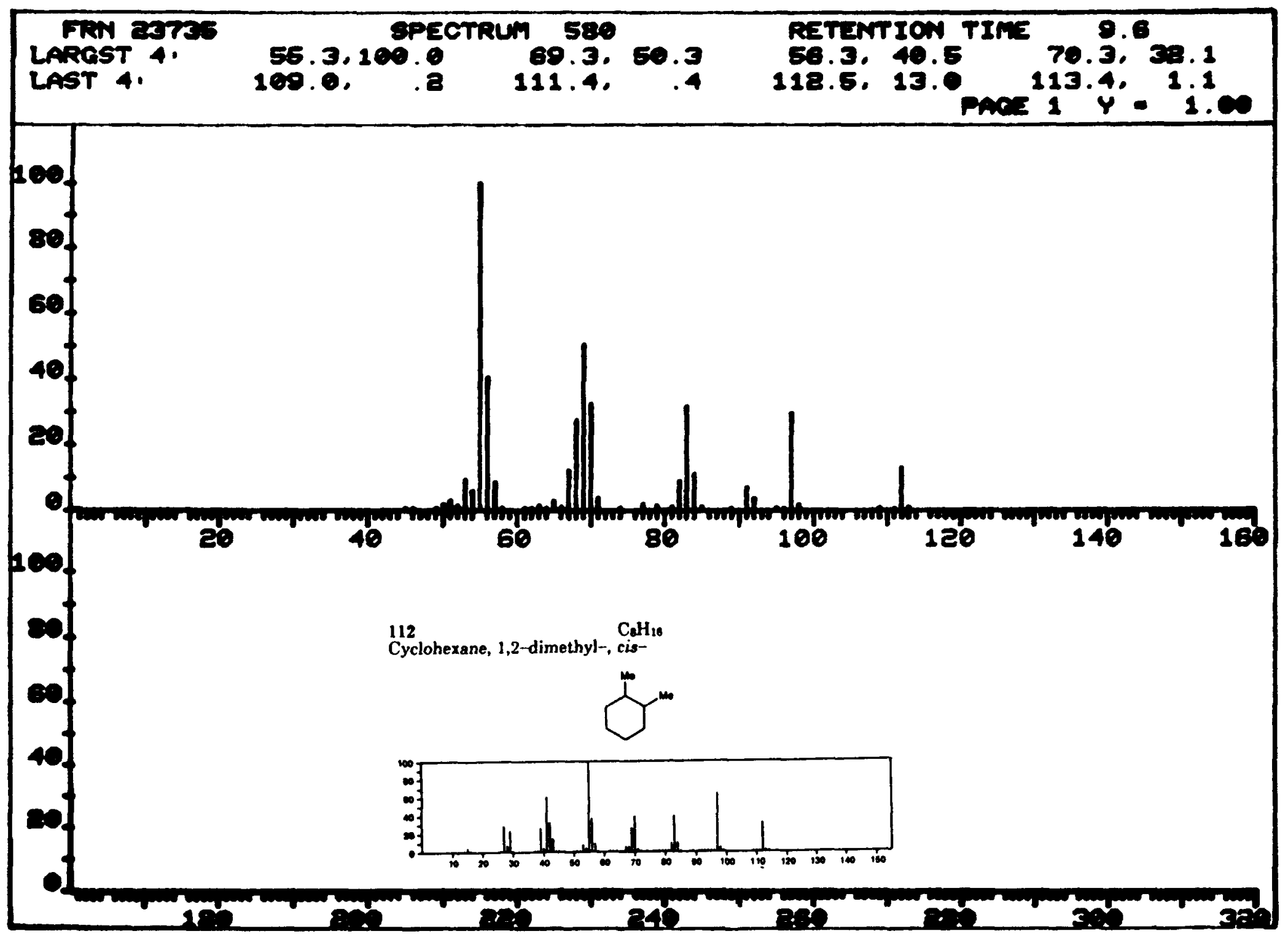

FIGURE B.17 Peak at 9.6 min: Dimethylcyclohexane Isomer 


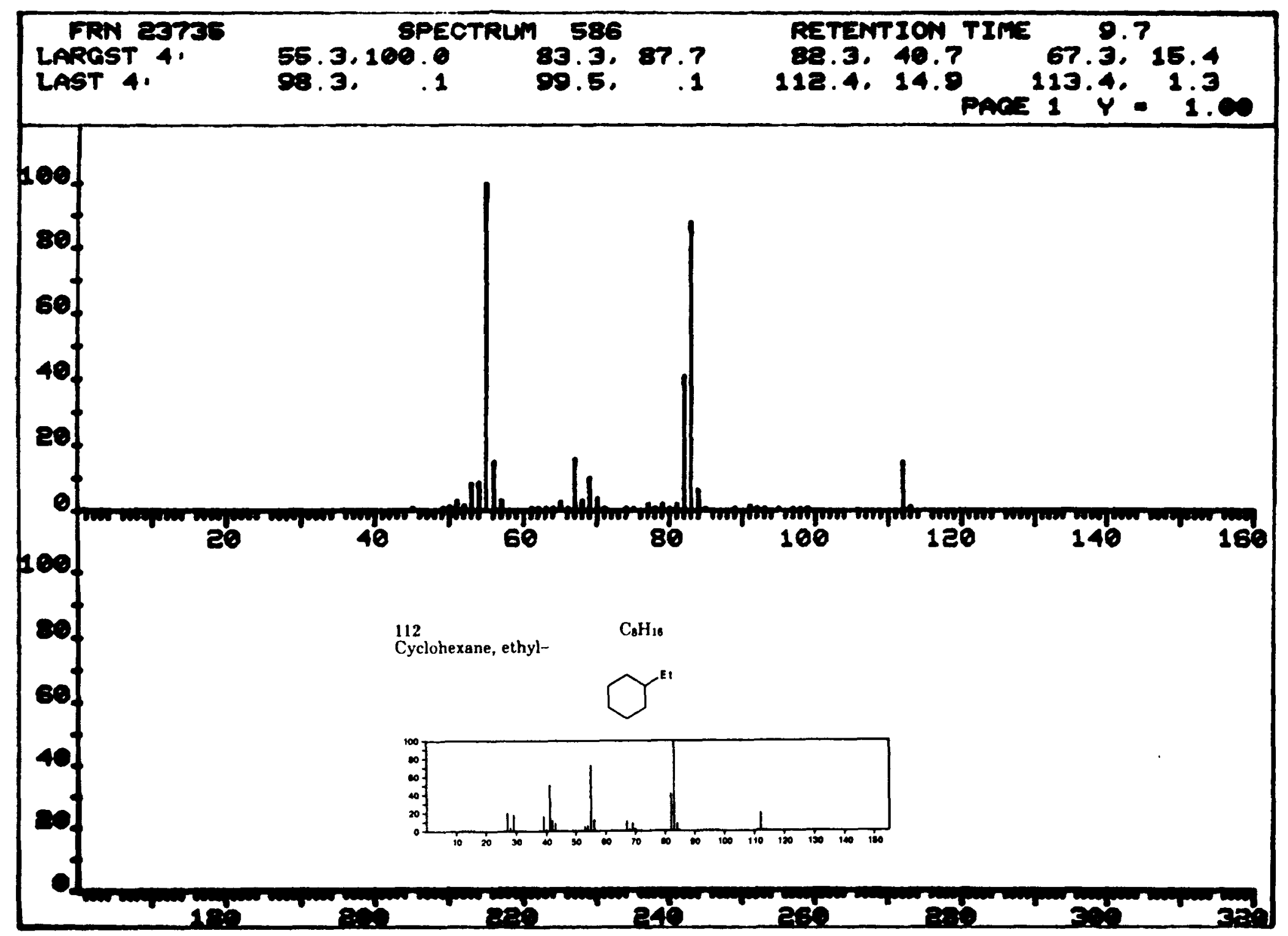

FIGURE B.18 Peak at 9.7 min: Ethylcyclohexane 


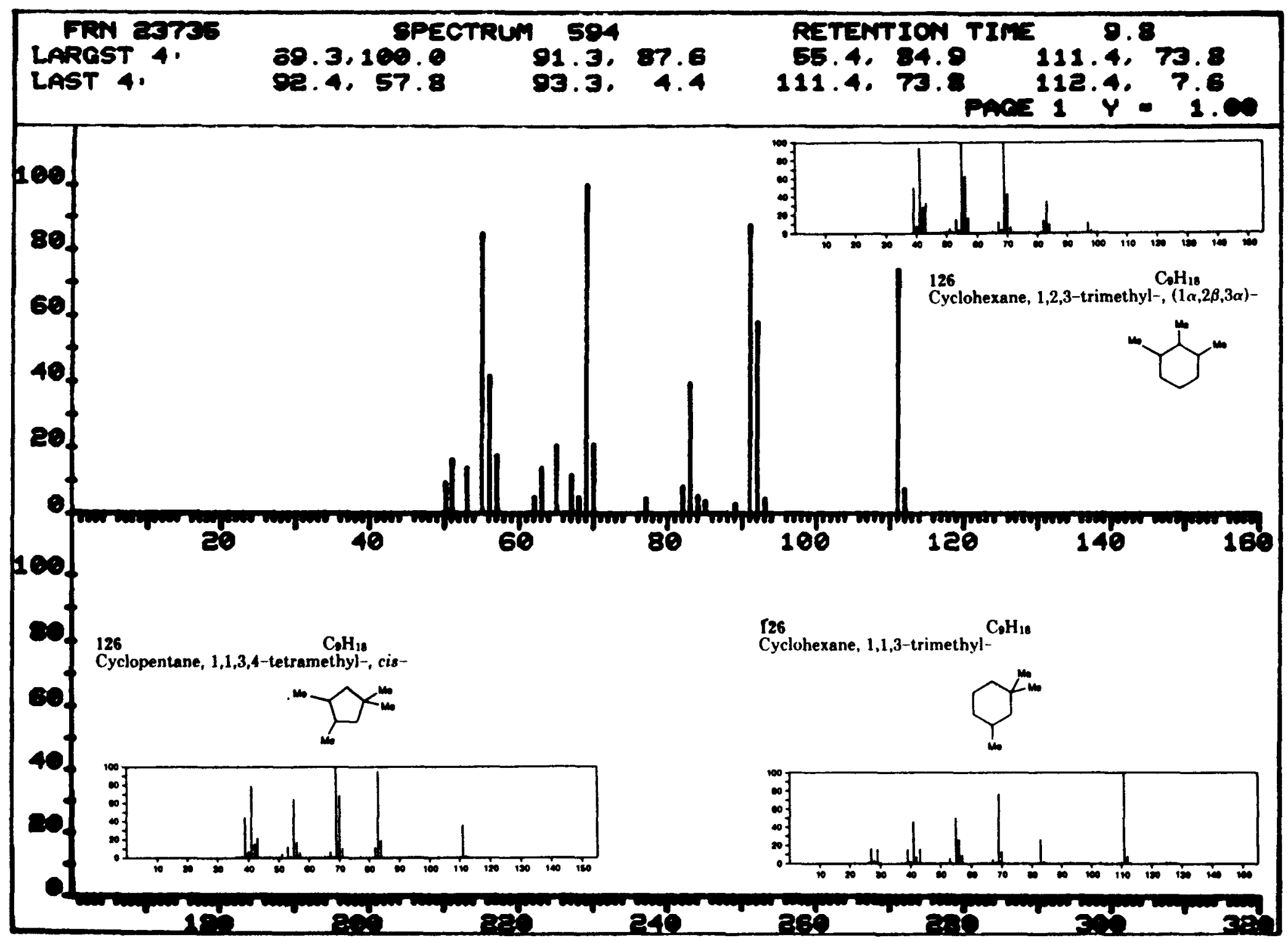

FIGURE B.19 Peak at 9.8 min: A C9 Cycloalkane 


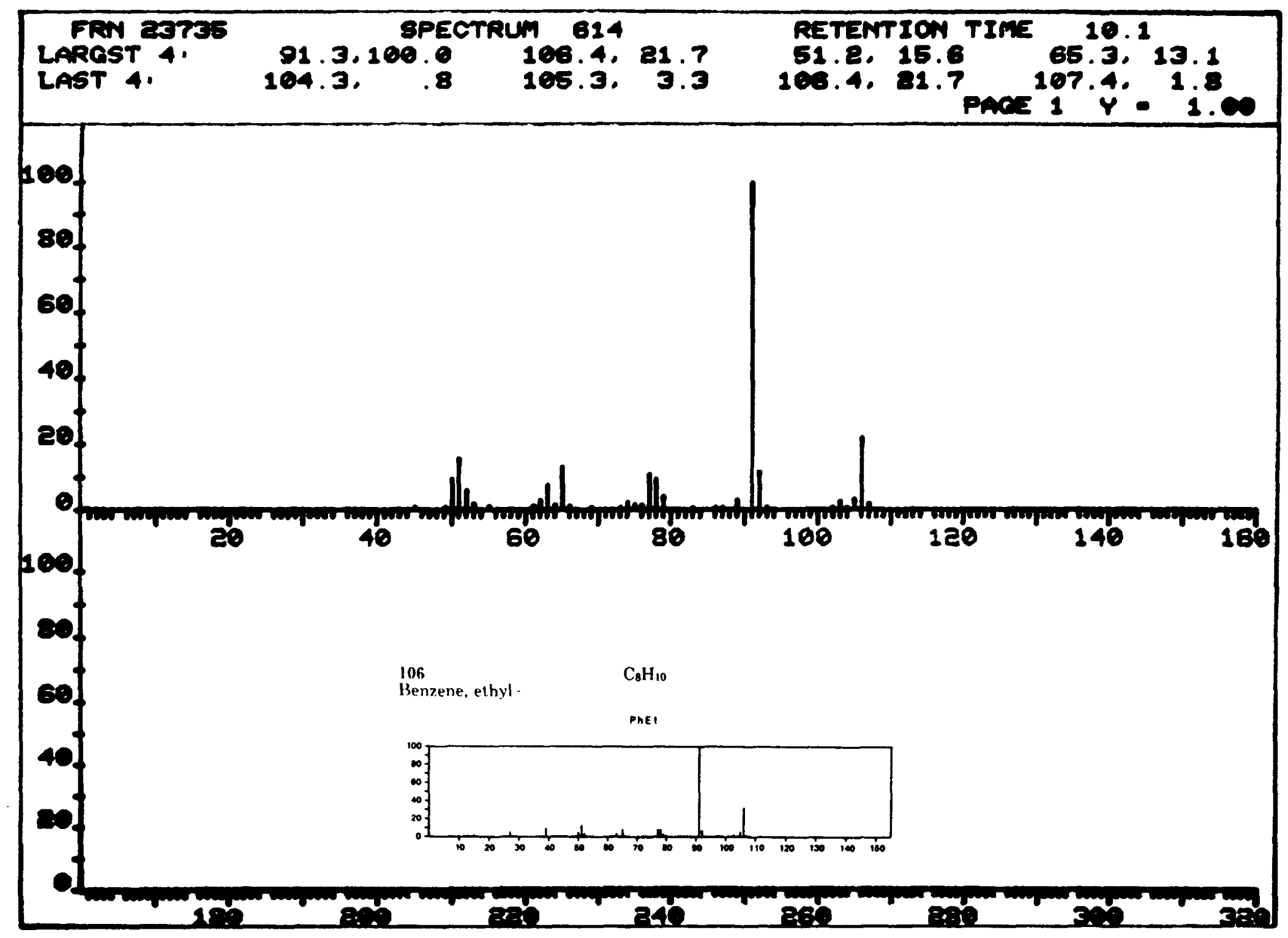

FIGURE B.20 Peak at 10.1 min: Ethylbenzene 


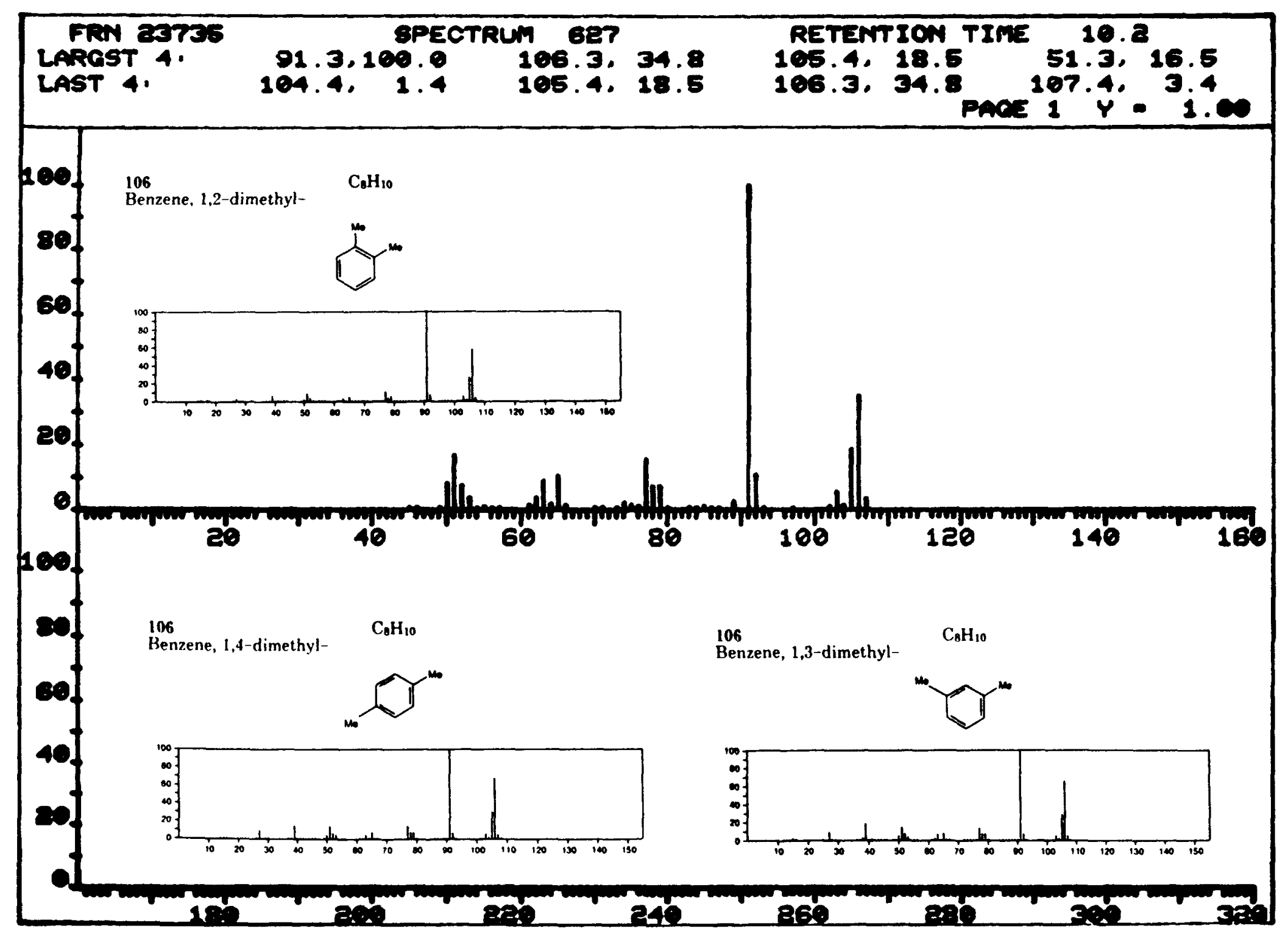

FIGURE B.21 Peak at 10.2 min: Xylene Isomer 


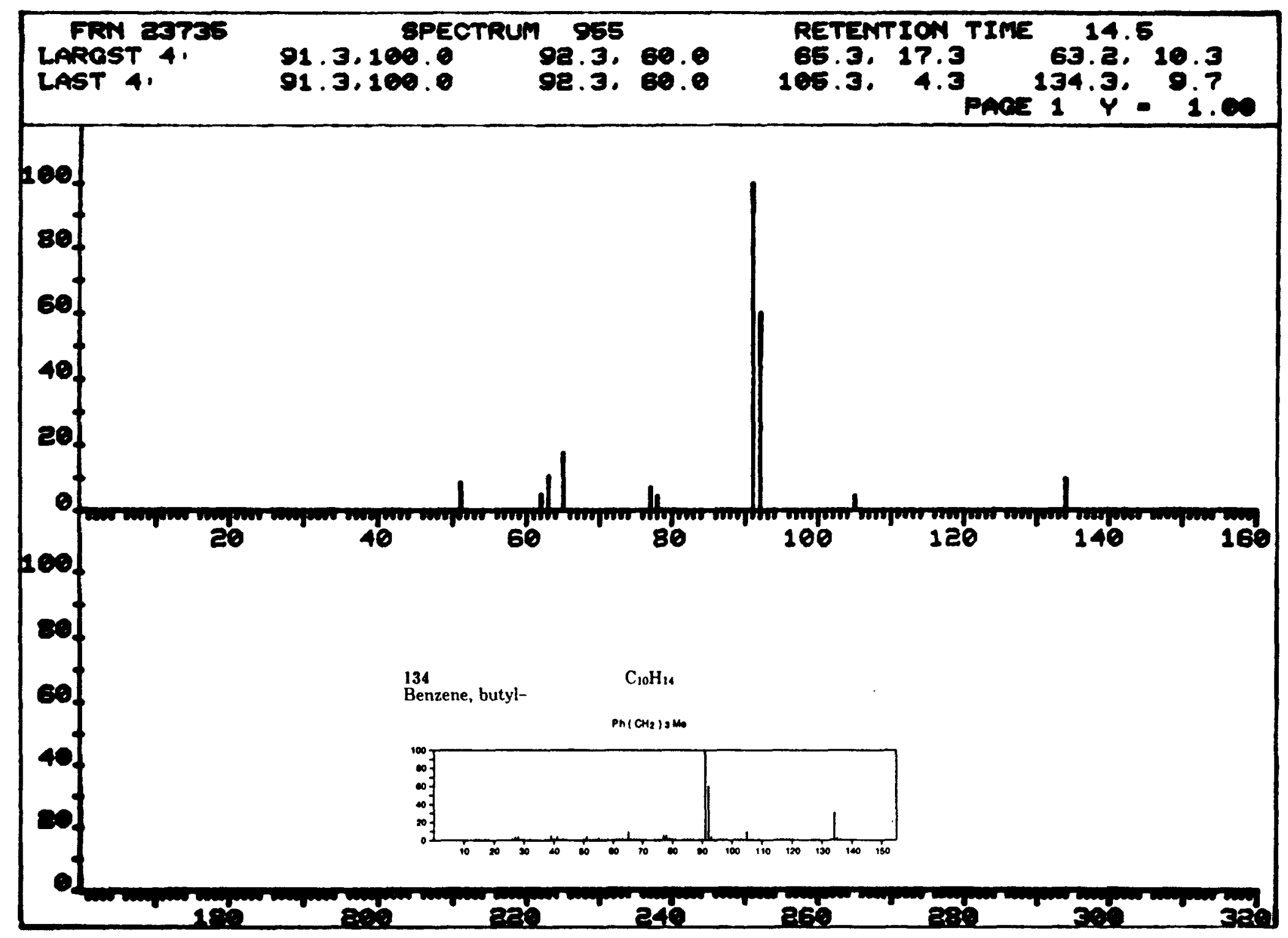

FIGURE B.22 Peak at 14.5 min: C4-Benzene Isomer 


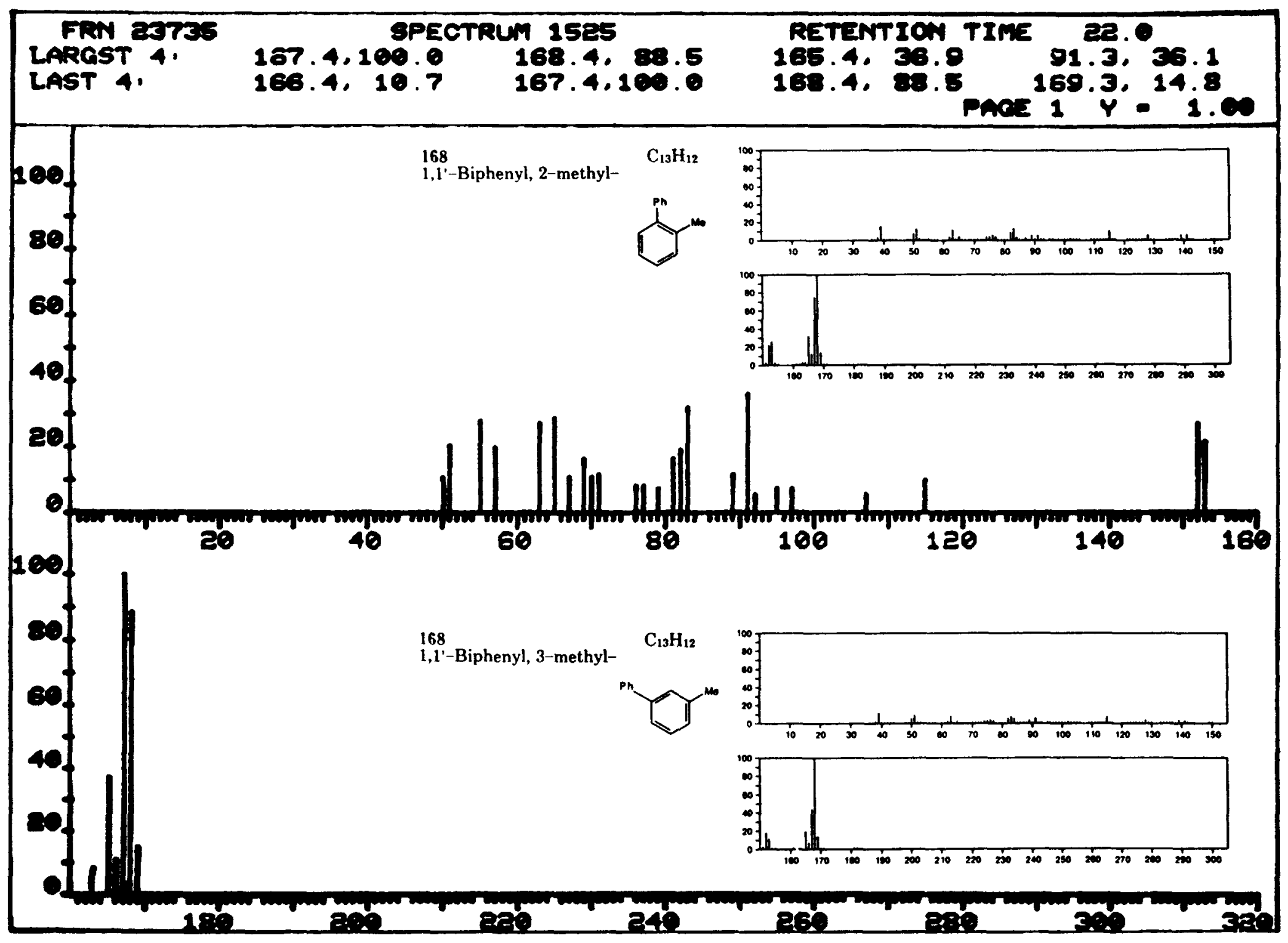

FIGURE B.23 Peak at 22.0 min: Methylbiphenyl Isomer 


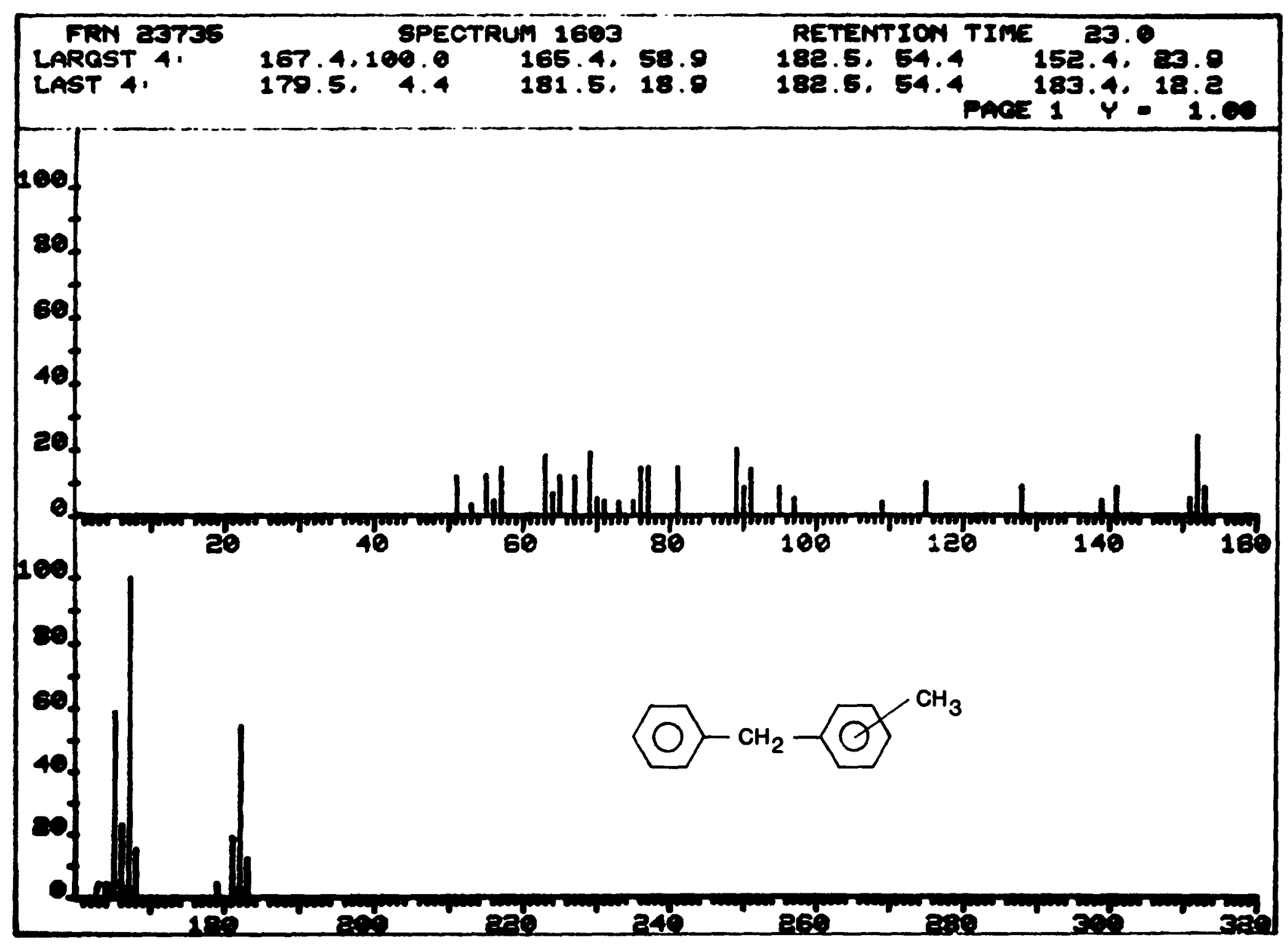

FIGURE B.24 Peak at 23.0 min: C1-Diphenylmethane Isomer 


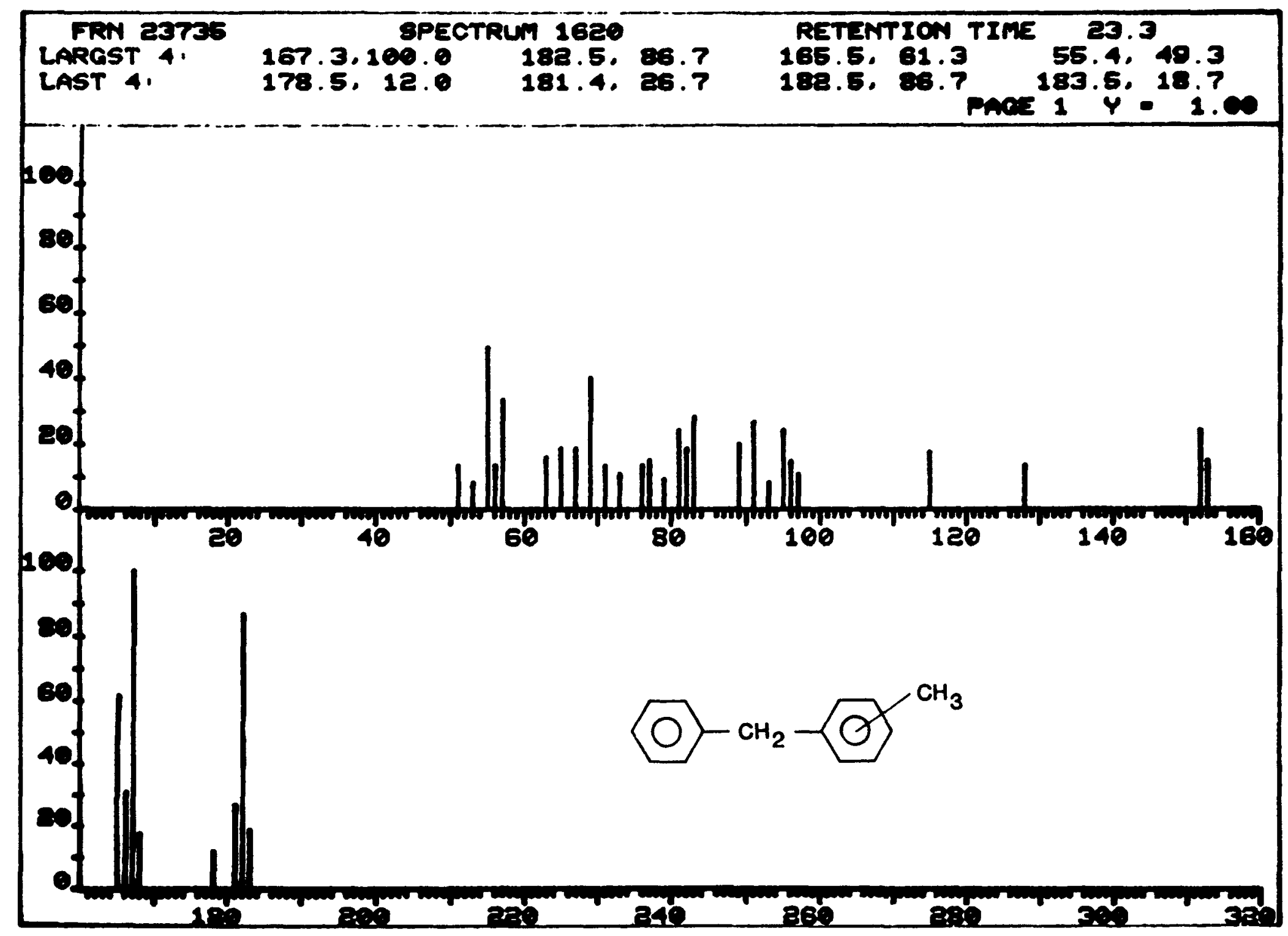

FIGURE B.25 Peak at 23.3 min: C1-Diphenylmethane Isomer 


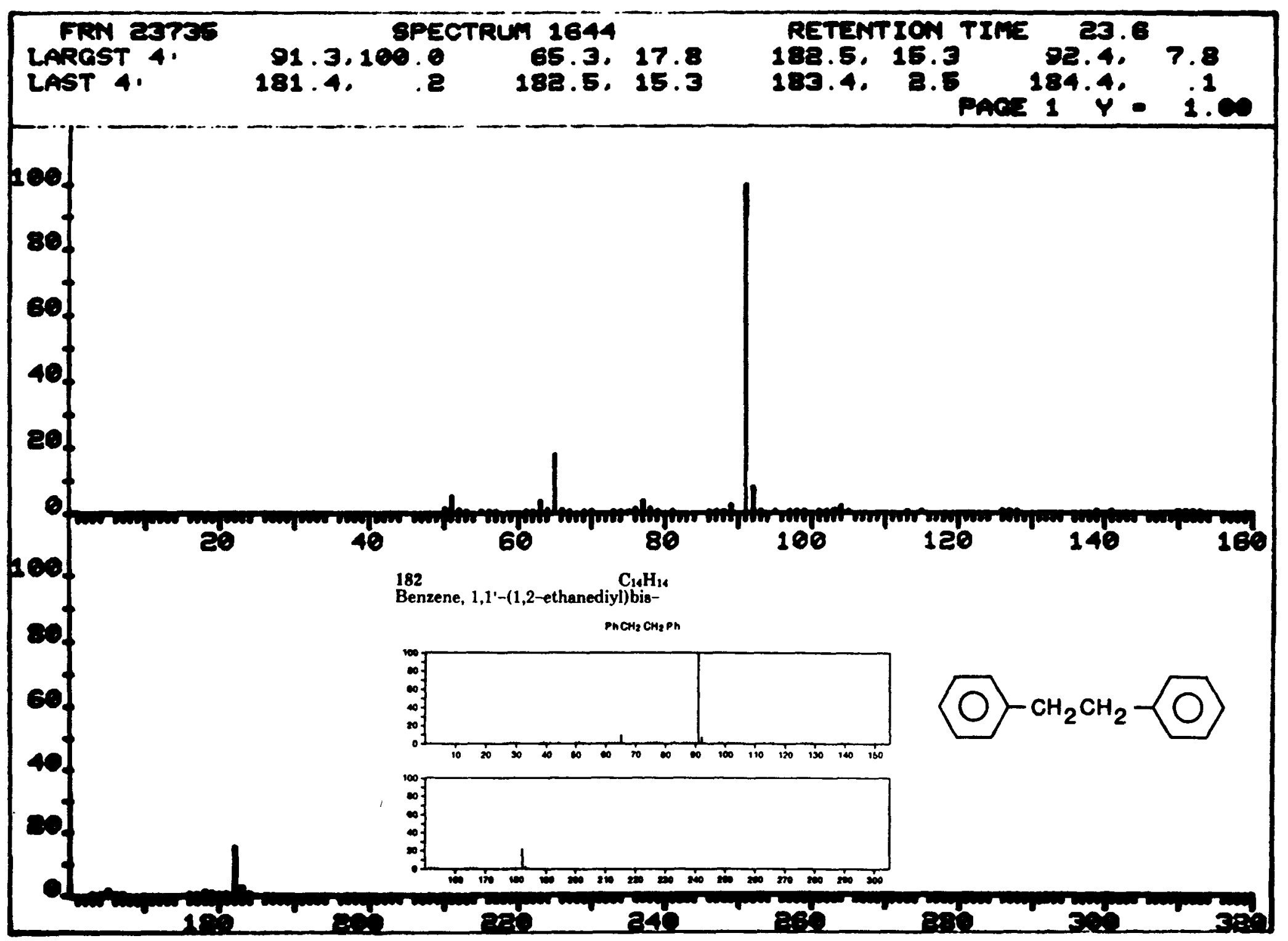

FIGURE B.26 Peak at 23.6 min: Bibenzyl 


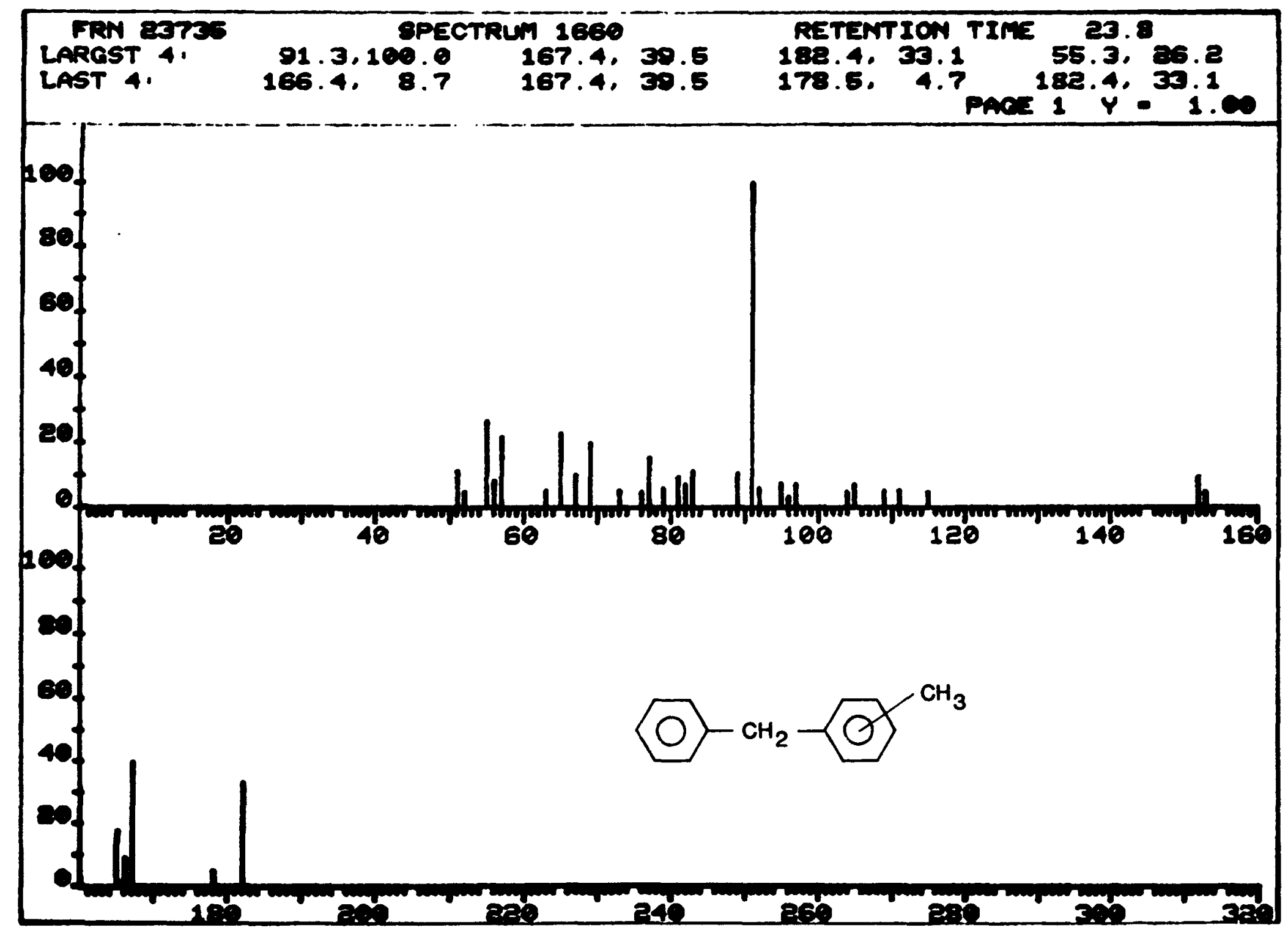

FIGURE B.27 Peak at $23.8 \mathrm{~min}$ C1-Diphenylmethane Isomer 


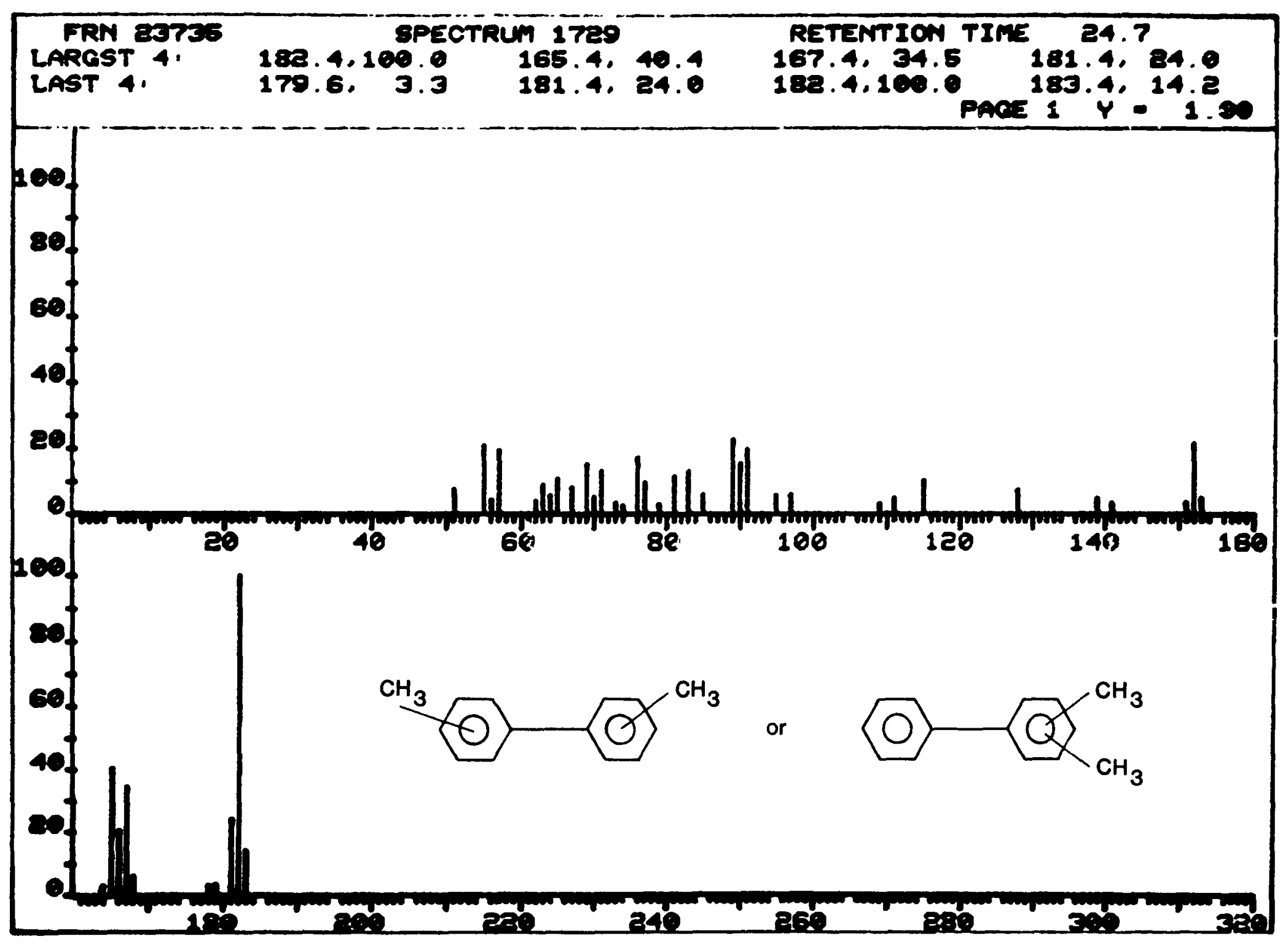

FIGURE B.28 Peak at 24.7 min: Dimethylbiphenyl Isomer 


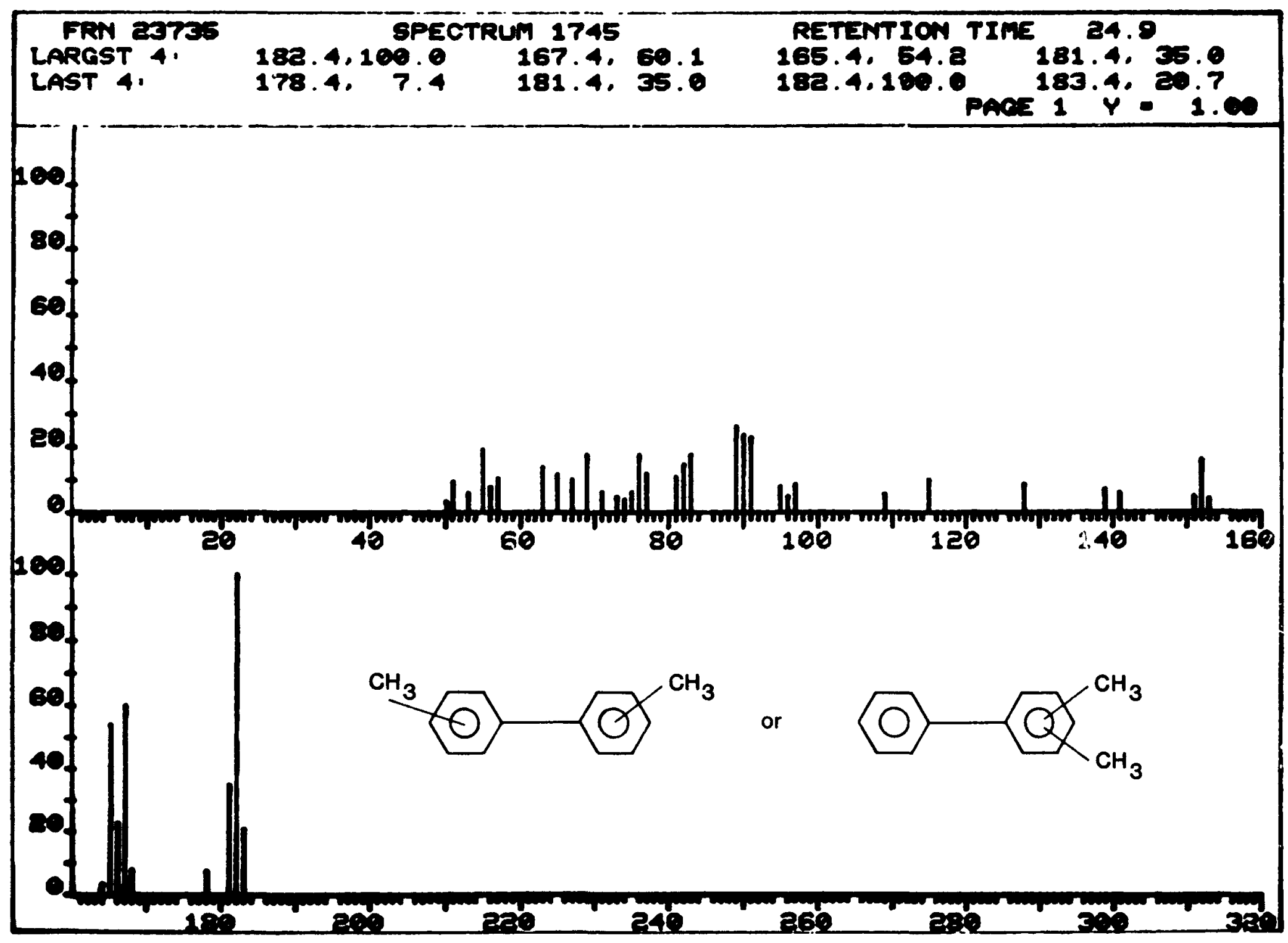

FIGURE B.29 Peak at 24.9 min: Dimethylbiphenyl Isomer 


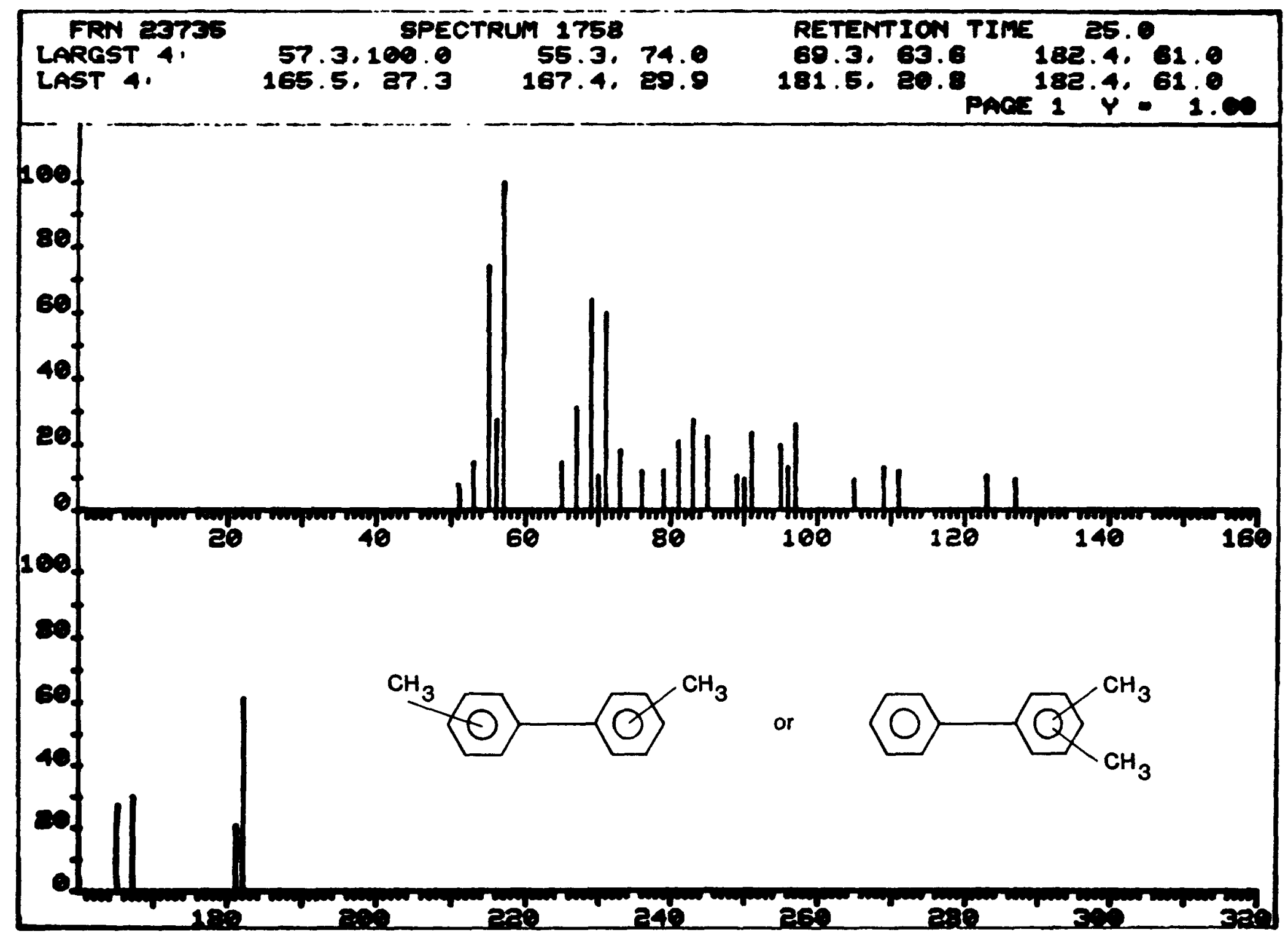

FIGURE B.30 Peak at 25.0 min: Dimethylbiphenyl Isomer 


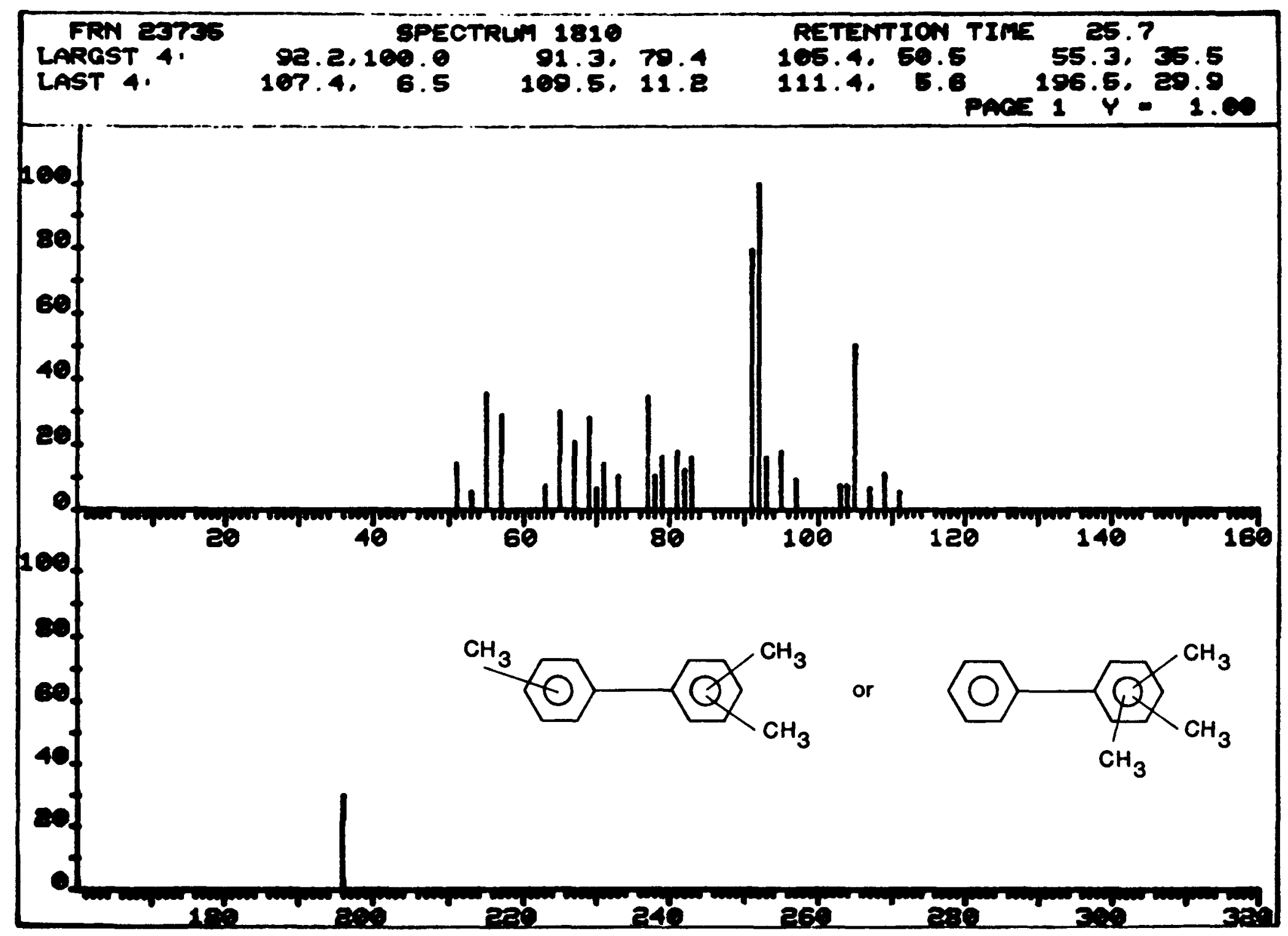

FIGURE B.31 Peak at 25.7 min: C3-Biphenyl Isomer 


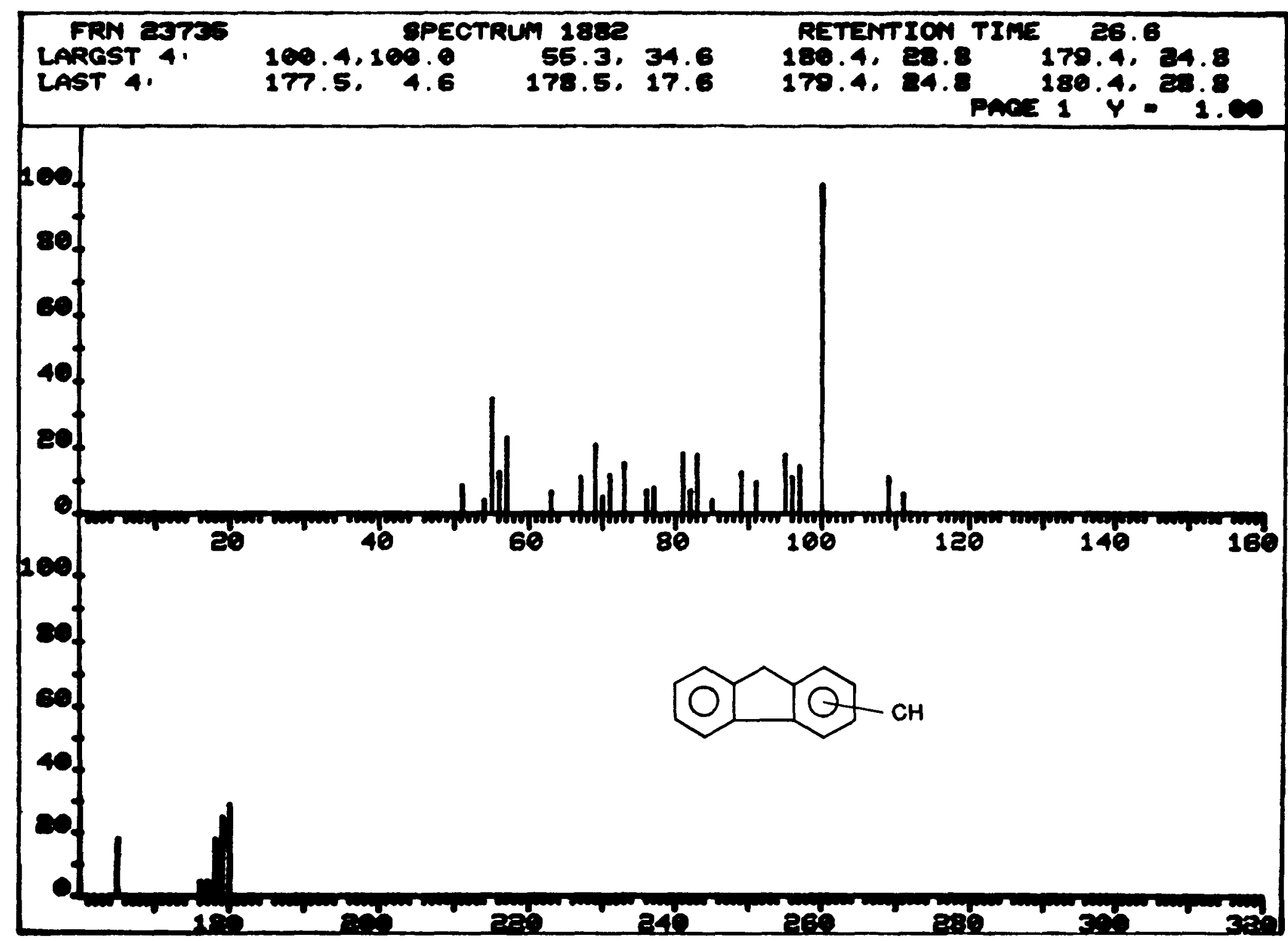

FIGURE B.32 Peak at $26.6 \mathrm{~min}$ Methylfluorene Isomer 


$$
111 / / / 2
$$

APPENDIX C:

\section{GAS CHROMATOGRAMS OF}

LIQUID SAMPLES 



\section{APPENDIX C:}

\section{GAS CHROMATOGRAMS OF LIQUID SAMPLES}

Figures C.1-C.19 are gas chromatagrams obtained from liquid samples.

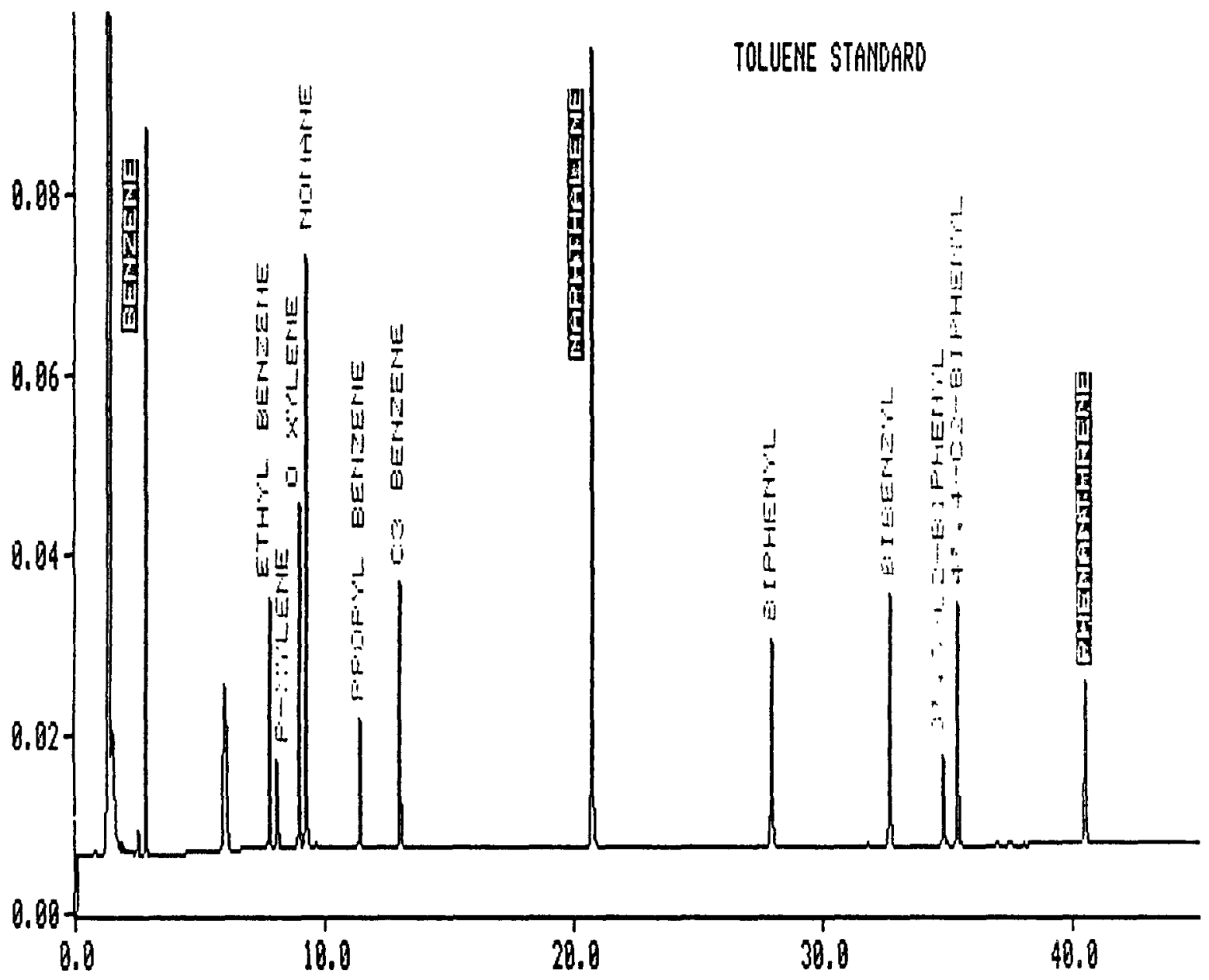

FIGURE C.1 Replotted Chromatogram of Toluene Standard 


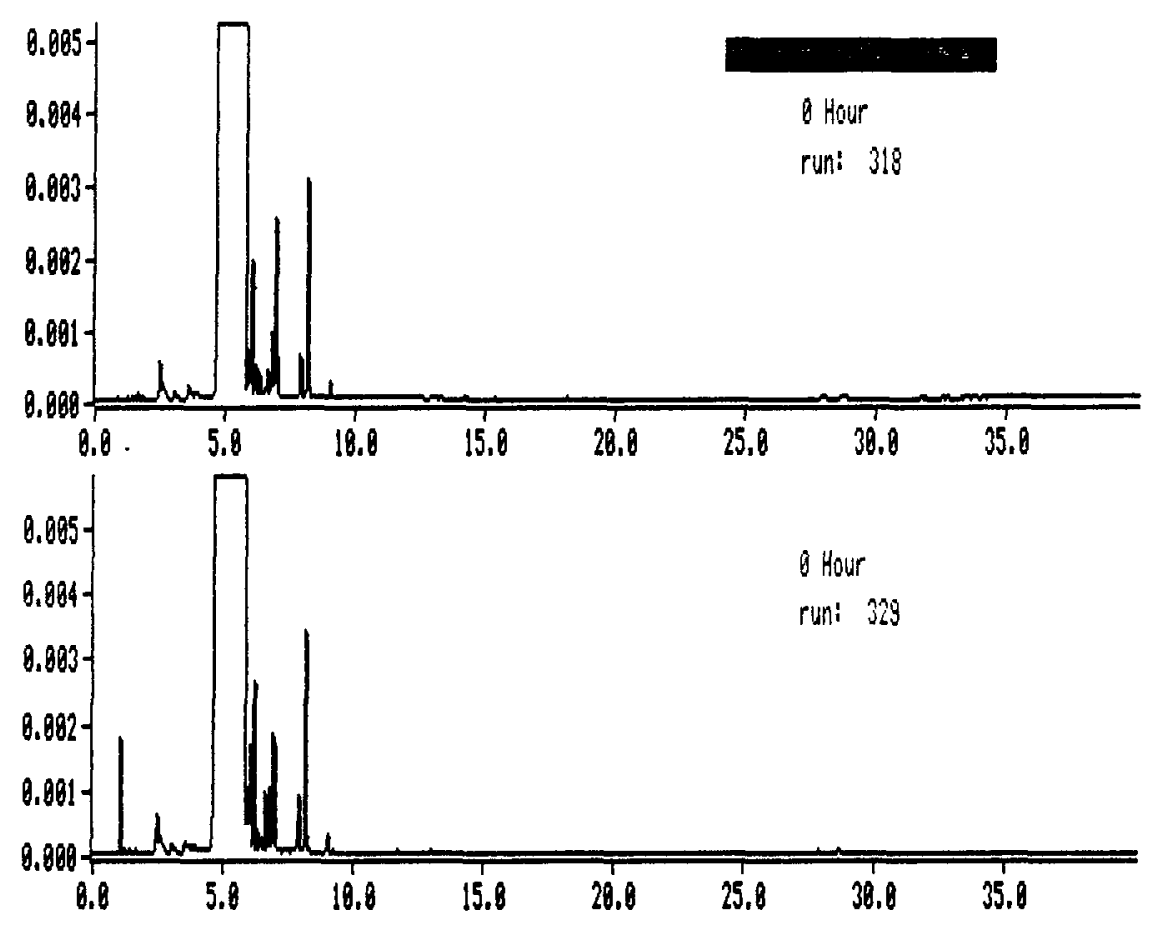

FIGURE C.2a Replotted Chromatograms for $635^{\circ} \mathrm{F}, 0 \mathrm{~h}$, Time Segment $=$ 0-40 min - Major Components

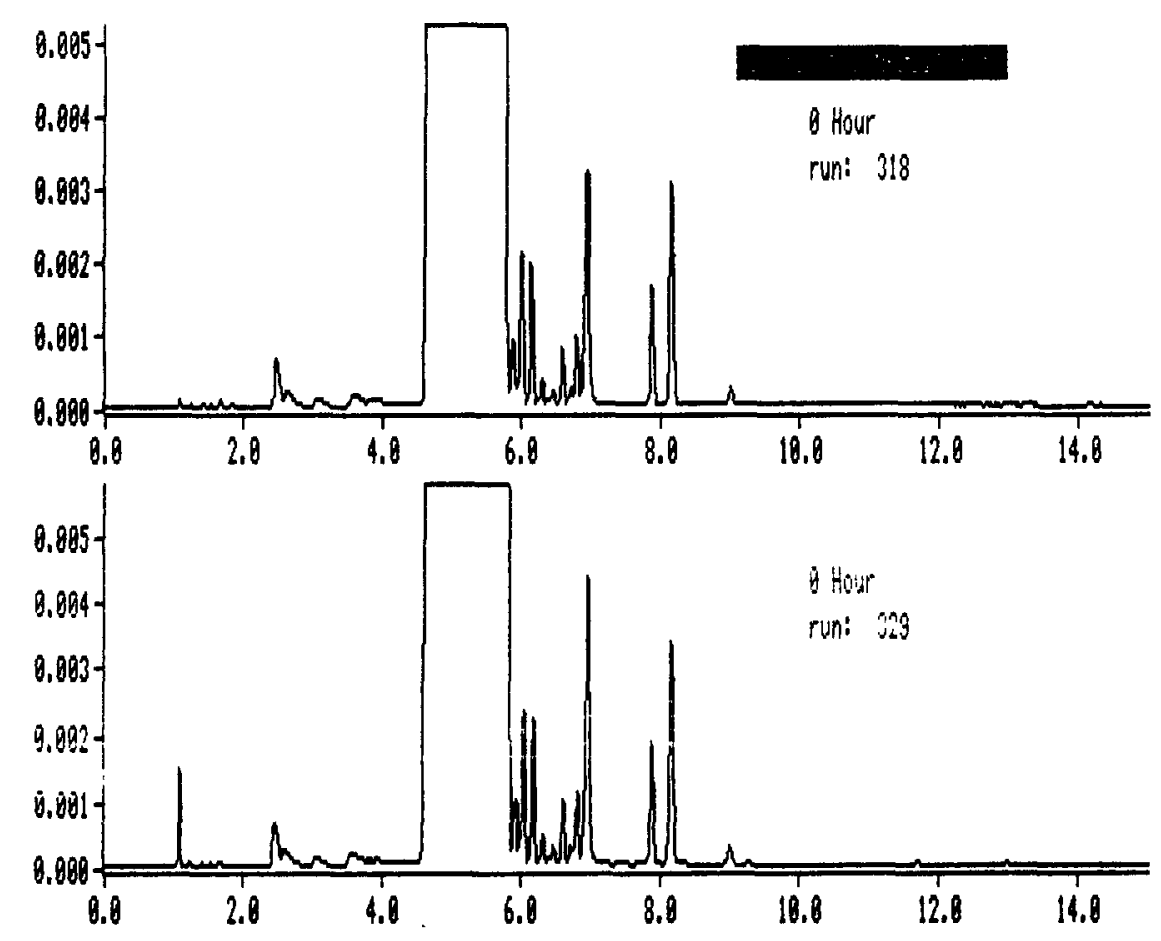

FIGURE C.2b Replotted Chromatograms for $635^{\circ} \mathrm{F}, 0 \mathrm{~h}$, Time Segment $=$ 0-15 $\mathrm{min}-$ Toluene Impurities 

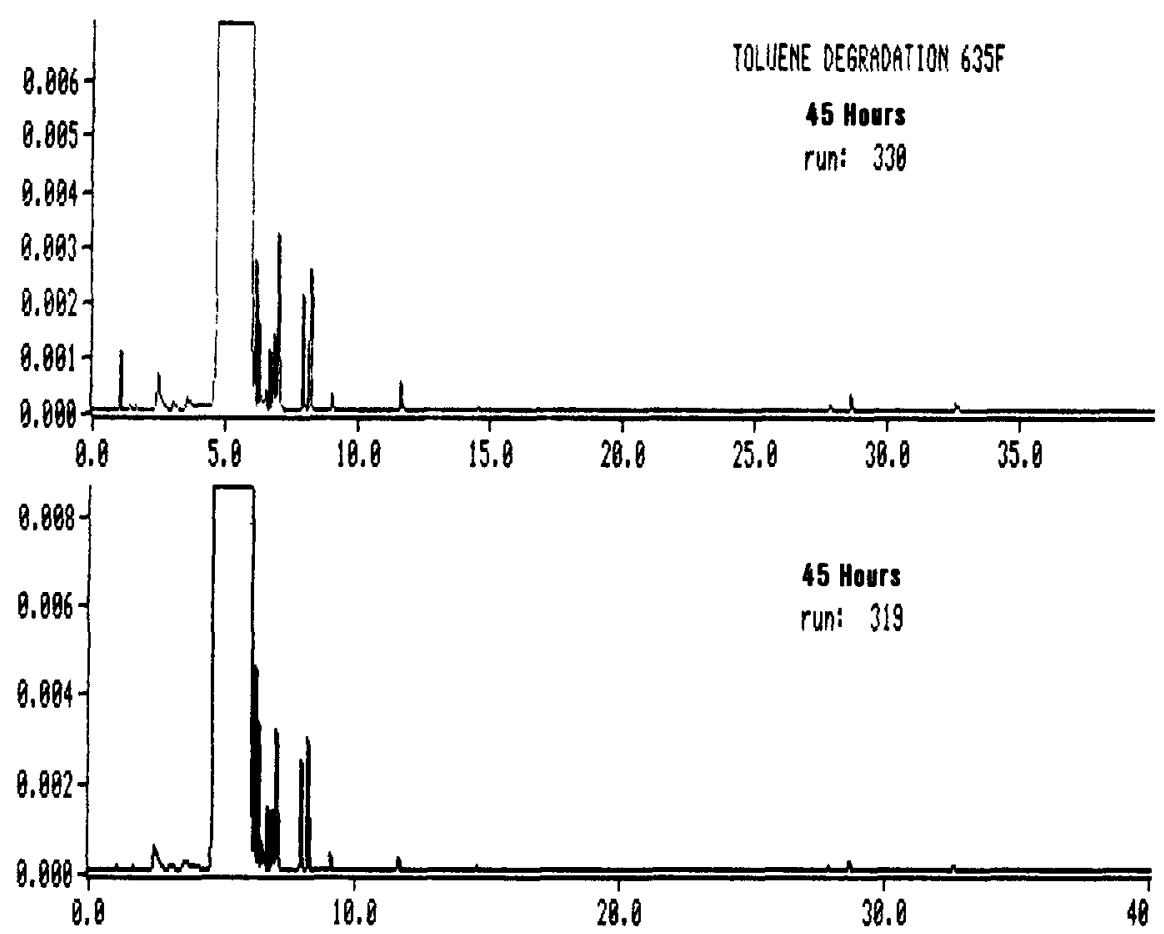

FIGURE C.3a Replotted Chromatograms for $635^{\circ} \mathrm{F}, 45 \mathrm{~h}$, Runs 330 and 319, Time Segment $=0-40 \mathrm{~min}-$ Major Components
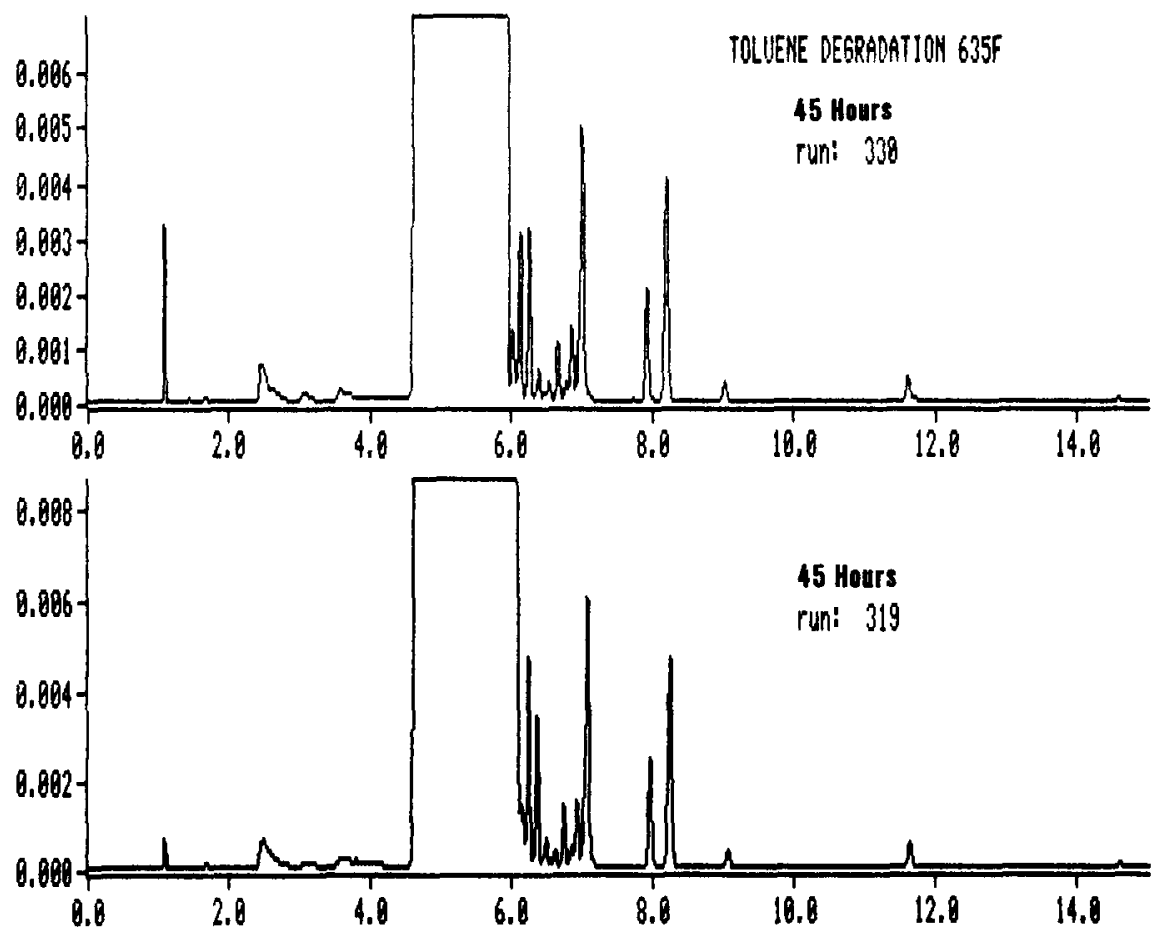

FIGURE C.3b Replotted Chromatograms for $635^{\circ} \mathrm{F}, 45 \mathrm{~h}$, Runs 330 and 319, Time Segment $=$ 0-15 $\mathrm{min}-$ Toluene Impurities 

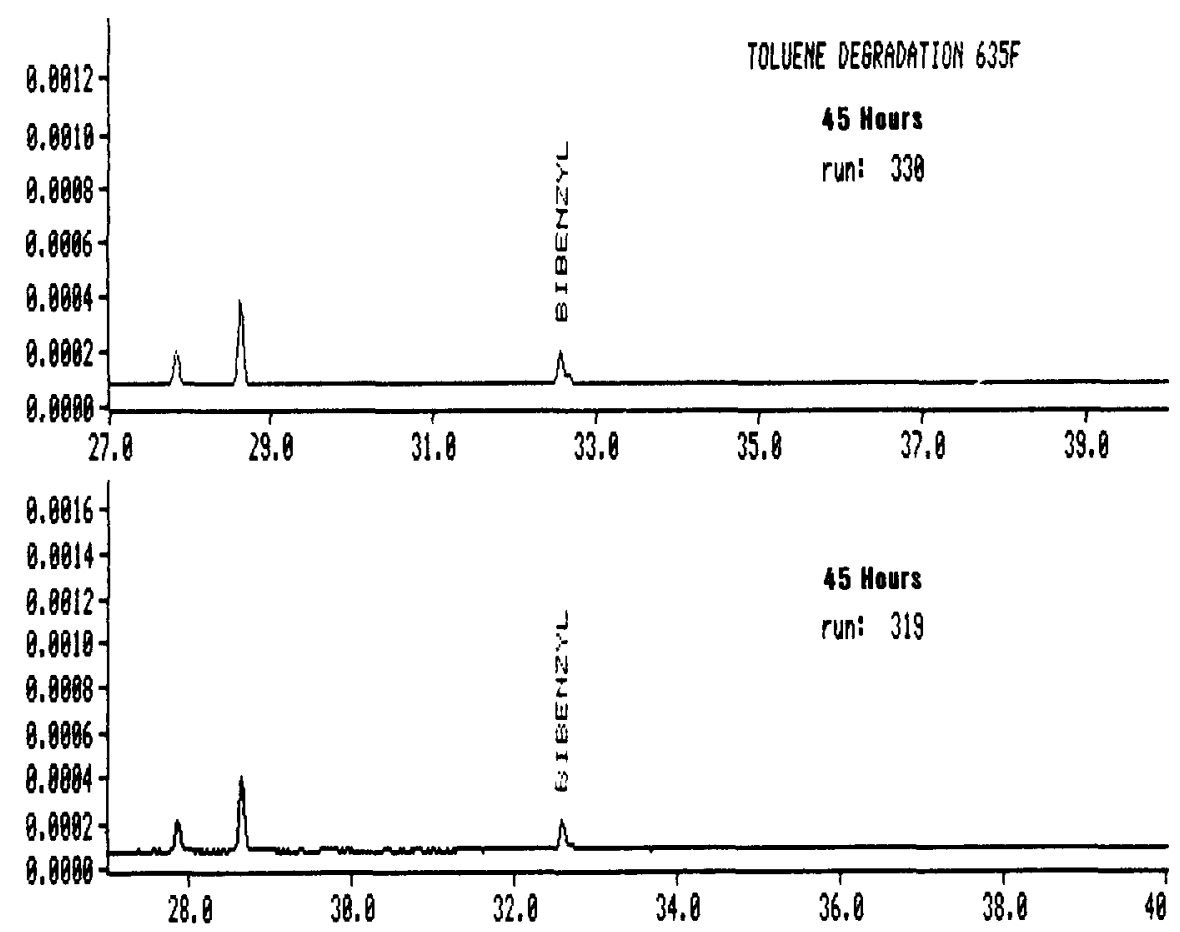

FIGURE C.3c Replotted Chromatograms for $635^{\circ} \mathrm{F}, 45 \mathrm{~h}$, Runs 330 and 319 , Time Segment $=27-40$ min - Degradation Products

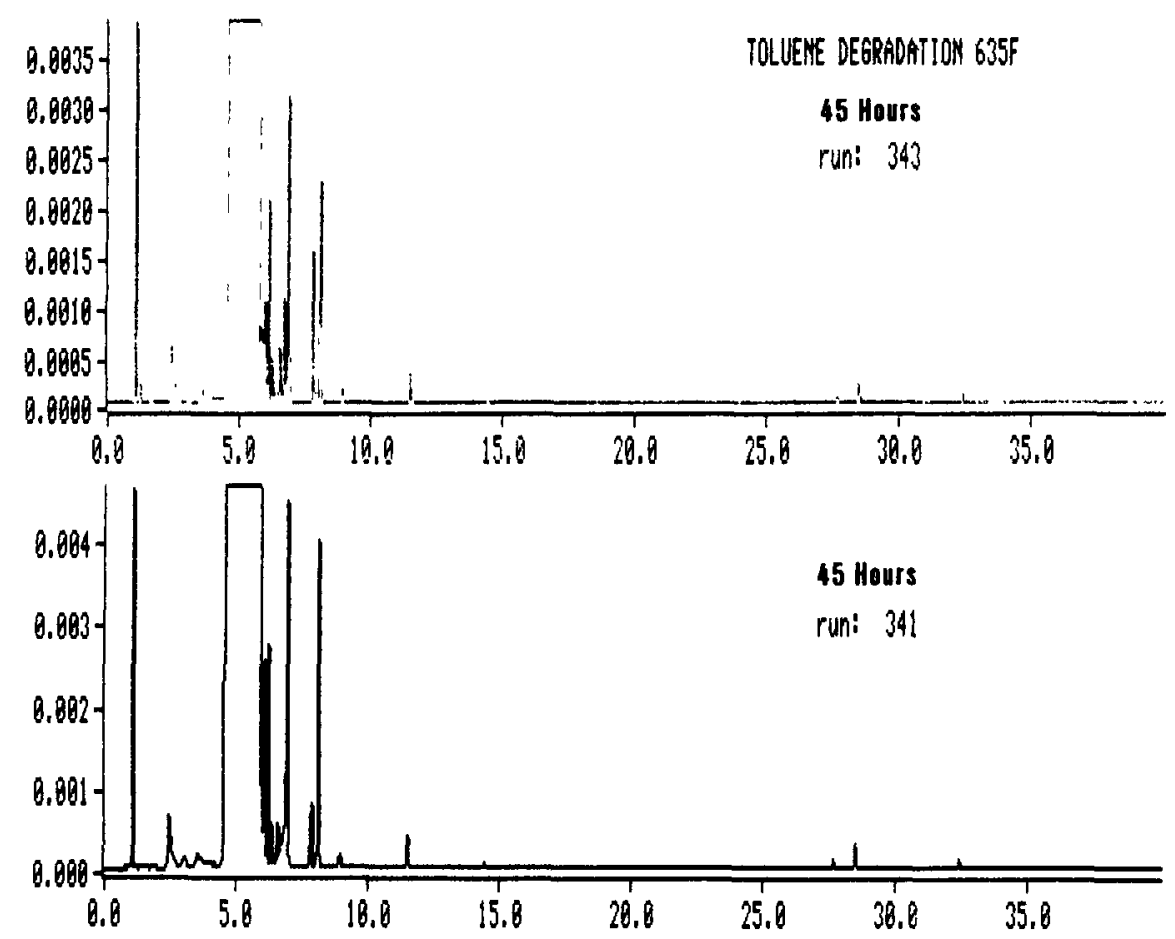

FIGURE C.4a Replotted Chromatograms for $635^{\circ} \mathrm{F}, 45 \mathrm{~h}$, Runs 343 and 341, Time Segment $=0-40 \mathrm{~min}-$ Major Components 


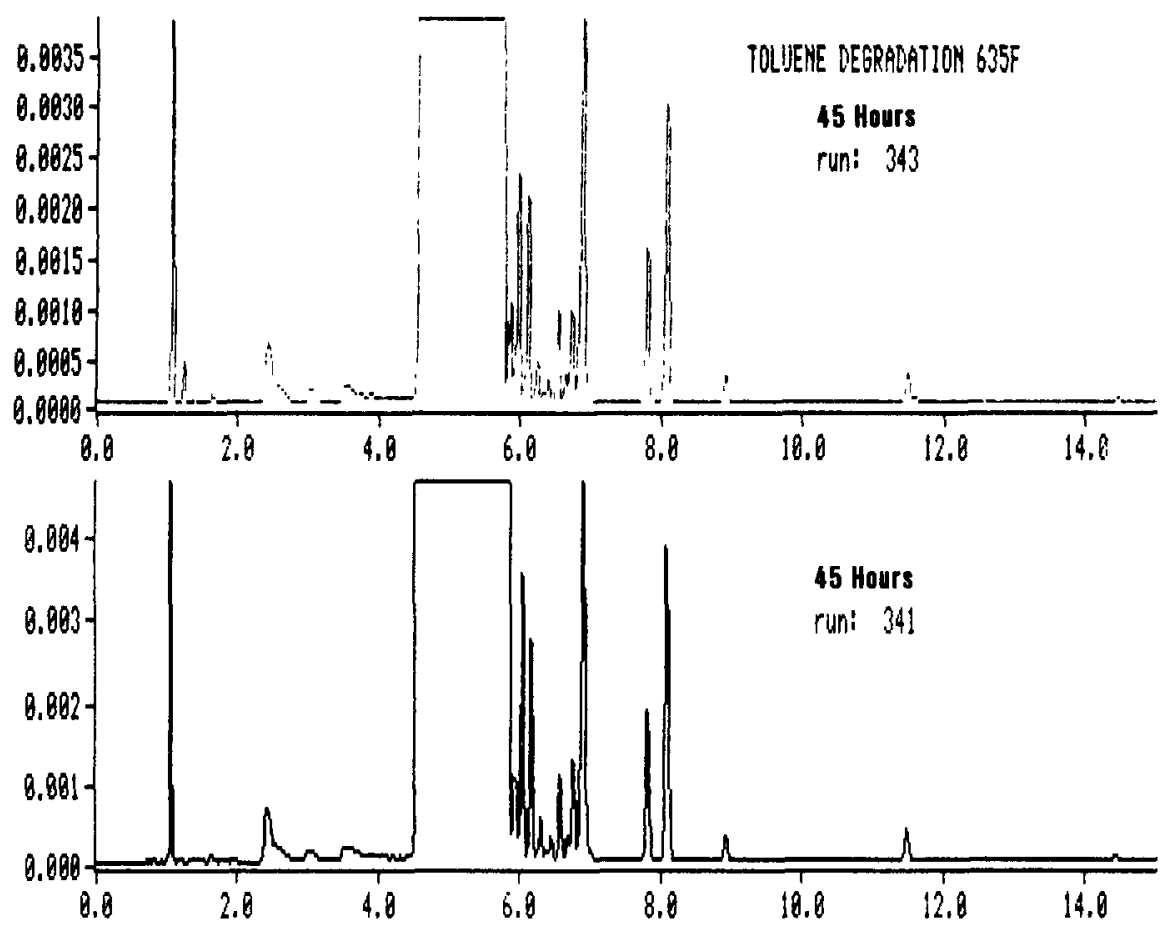

FIGURE C.4b Replotted Chromatograms for $635^{\circ} \mathrm{F}, 45 \mathrm{~h}$, Runs 343 and 341, Time Segment $=0$-15 min - Toluene Impurities
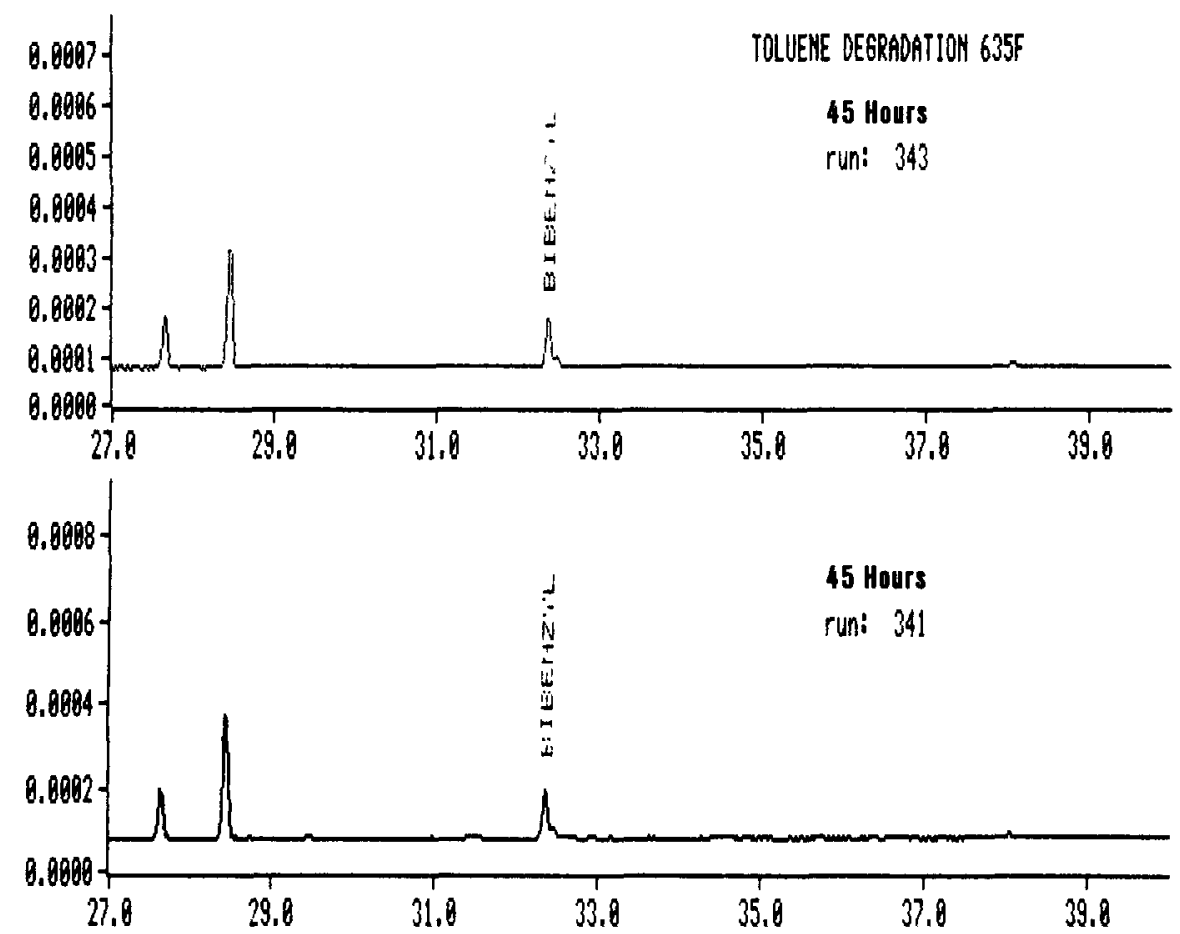

FIGURE C.4c Replotted Chromatograms for $635^{\circ} \mathrm{F}, 45 \mathrm{~h}$, Runs 343 and 341, Time Segment $=27-40 \mathrm{~min}-$ Degradation Products 


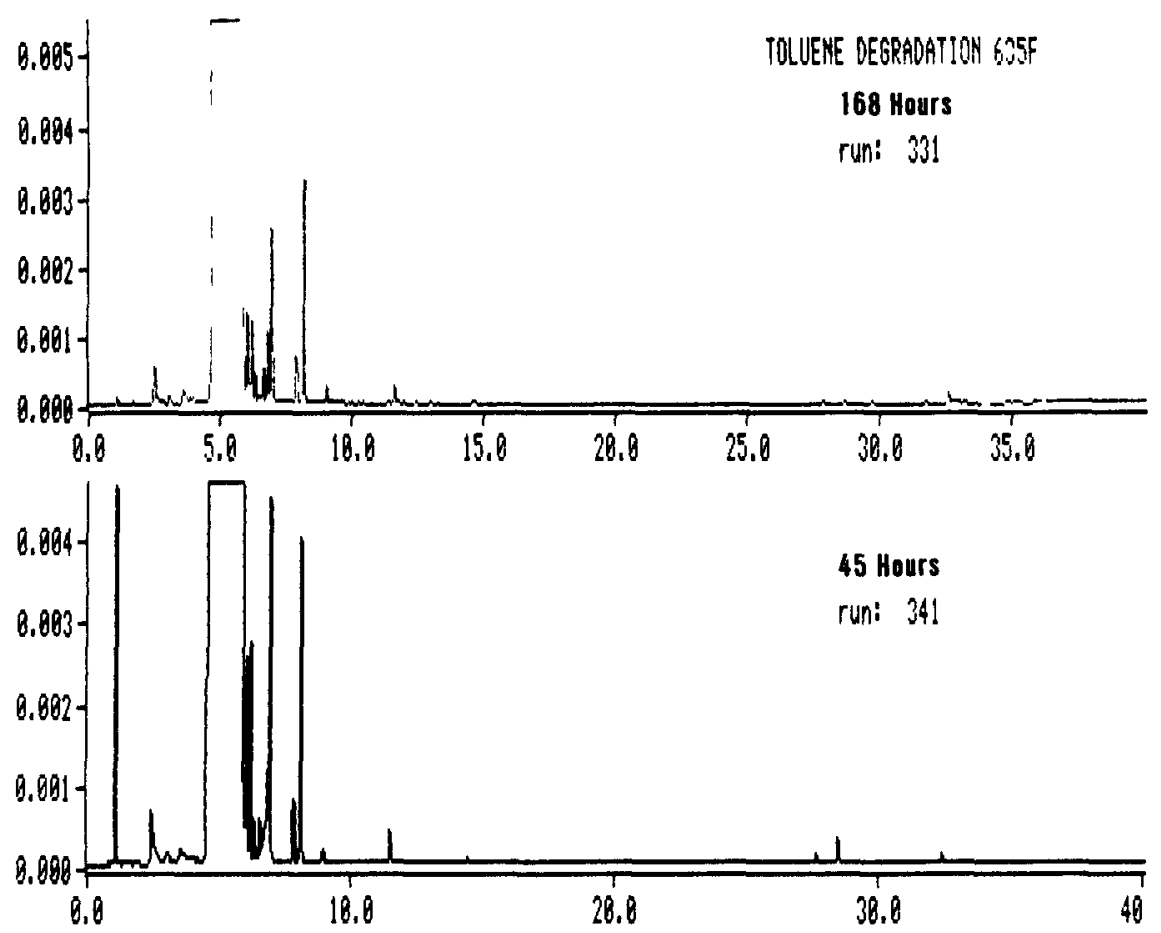

FIGURE C.5a Replotted Chromatograms for $635^{\circ} \mathrm{F}, 168$ and $45 \mathrm{~h}$, Runs 331 and 341, Time Segment $=0-40 \mathrm{~min}-$ Major Components

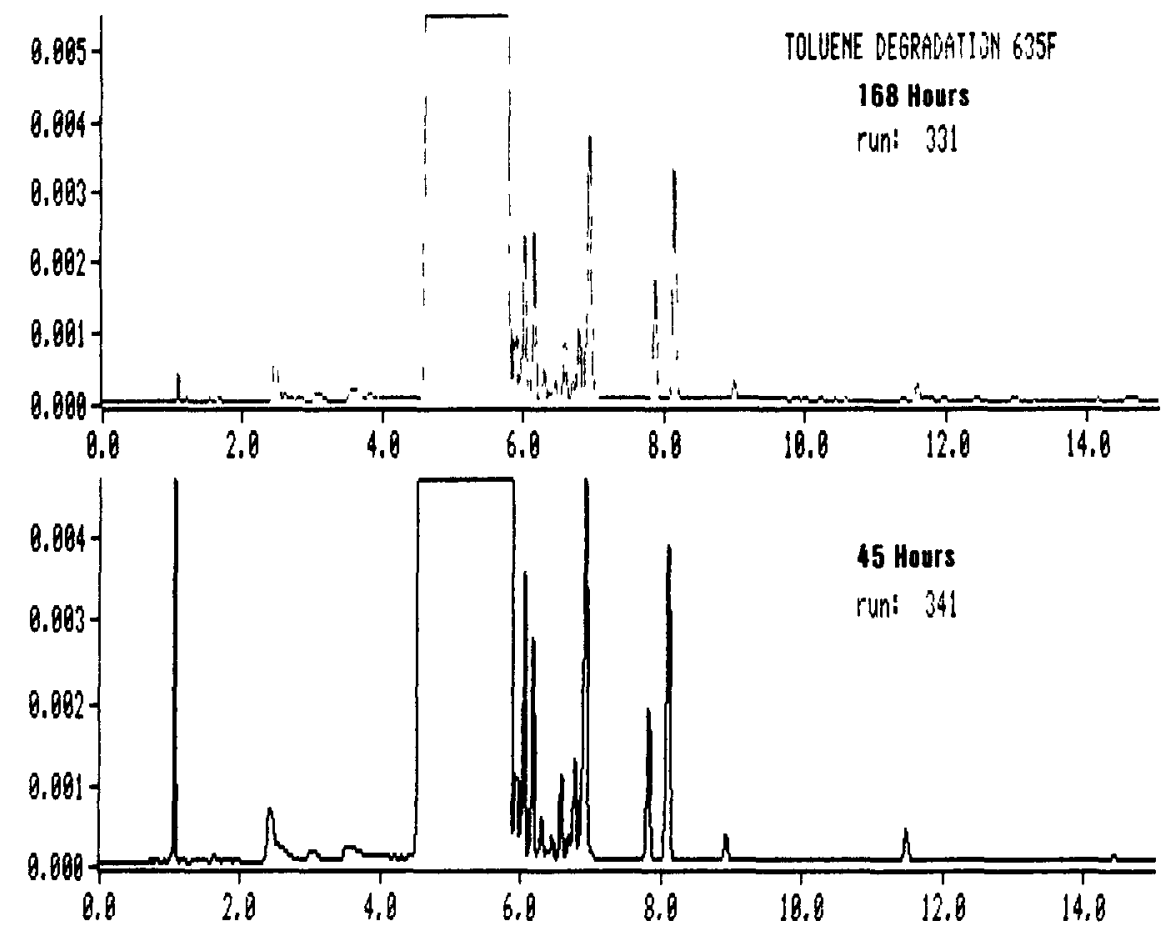

FIGURE C.5b Replotted Chromatograms for $635^{\circ} \mathrm{F}, 168$ and $45 \mathrm{~h}$, Runs 331 and 341, Time Segment $=0-15 \mathrm{~min}-$ Toluene Impurities 


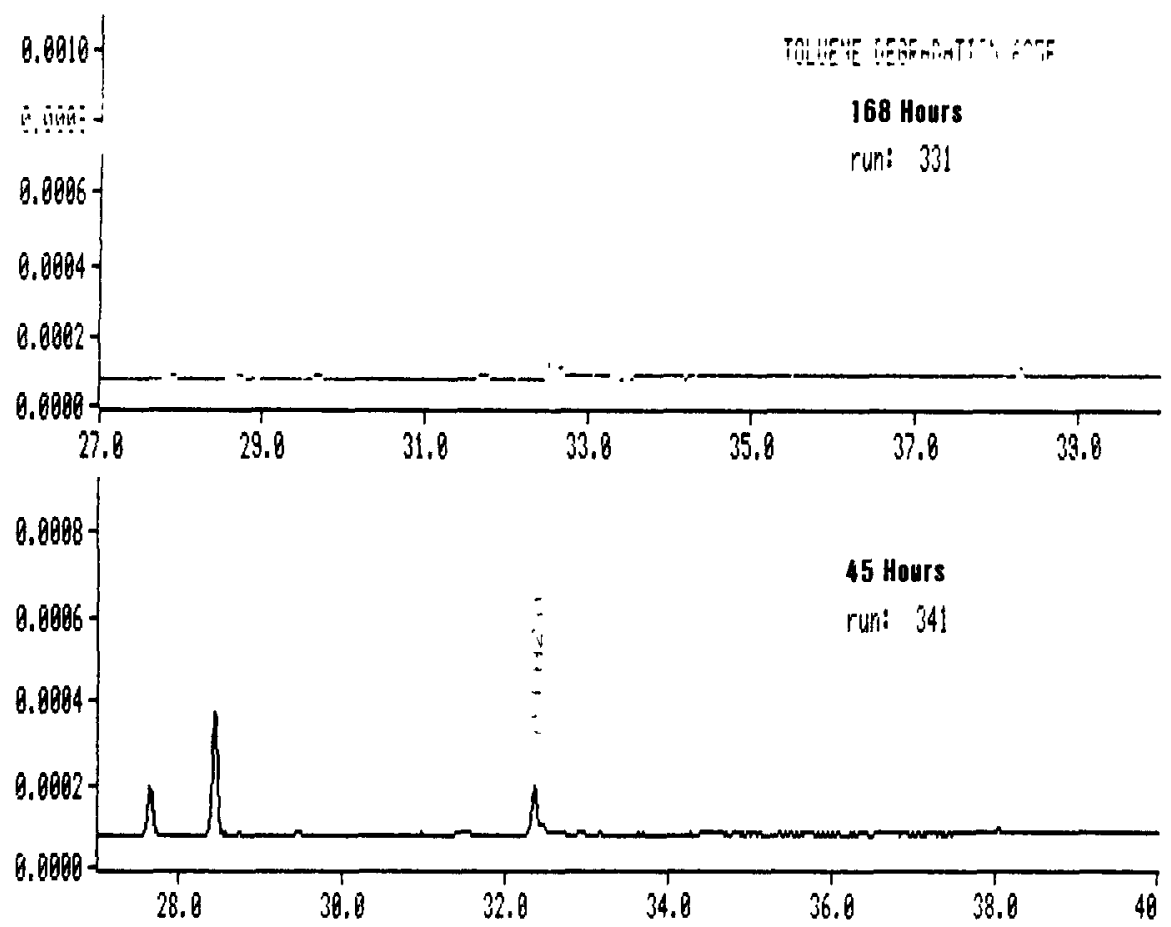

FIGURE C.5c Replotted Chromatograms for $635^{\circ} \mathrm{F}, 168$ and $45 \mathrm{~h}$, Runs 331 and 341, Time Segment $=27-40 \mathrm{~min}-$ Degradation Products

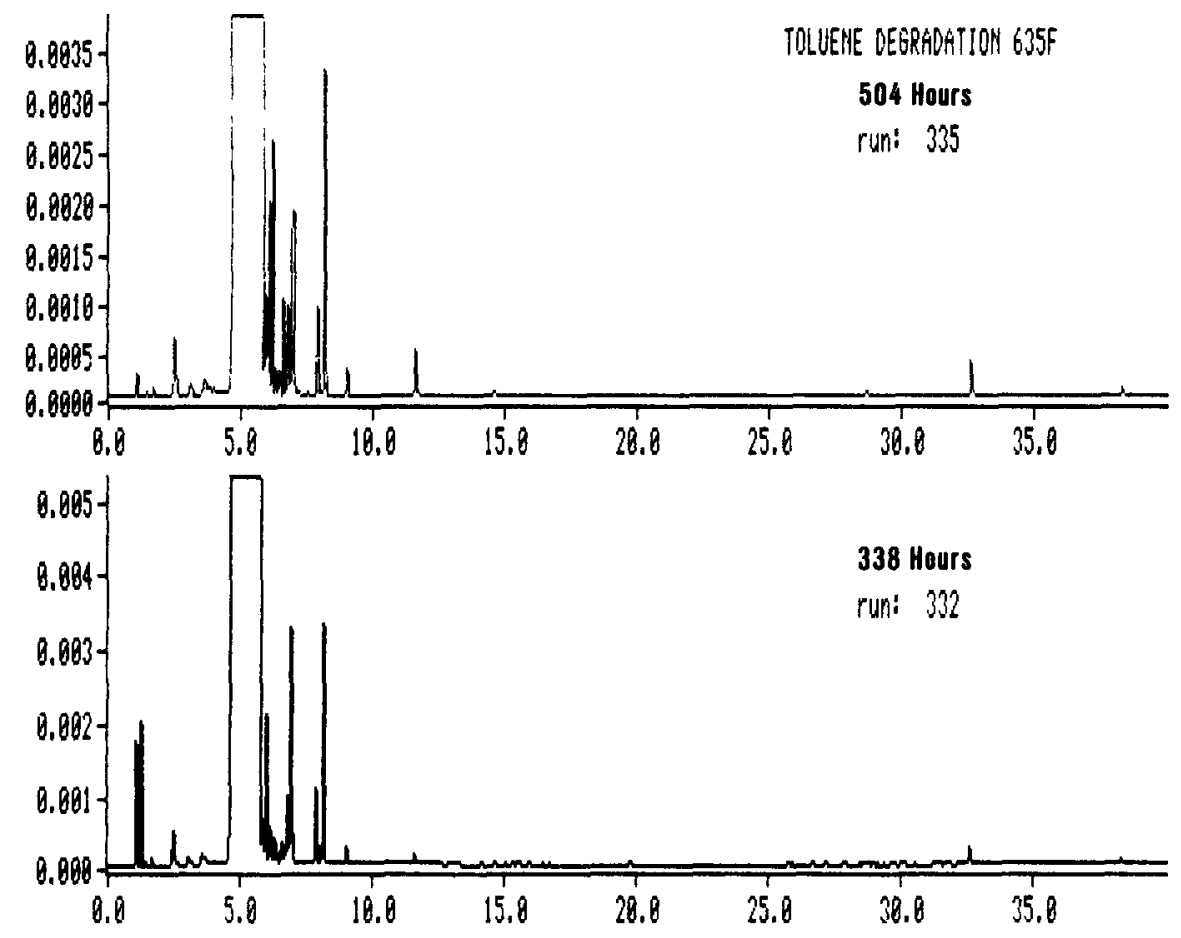

FIGURE C.6a Replotted Chromatograms for $635^{\circ} \mathrm{F}, 504$ and $338 \mathrm{~h}$, Runs 335 and 332, Time Segment $=$ 0-40 min - Major Components 


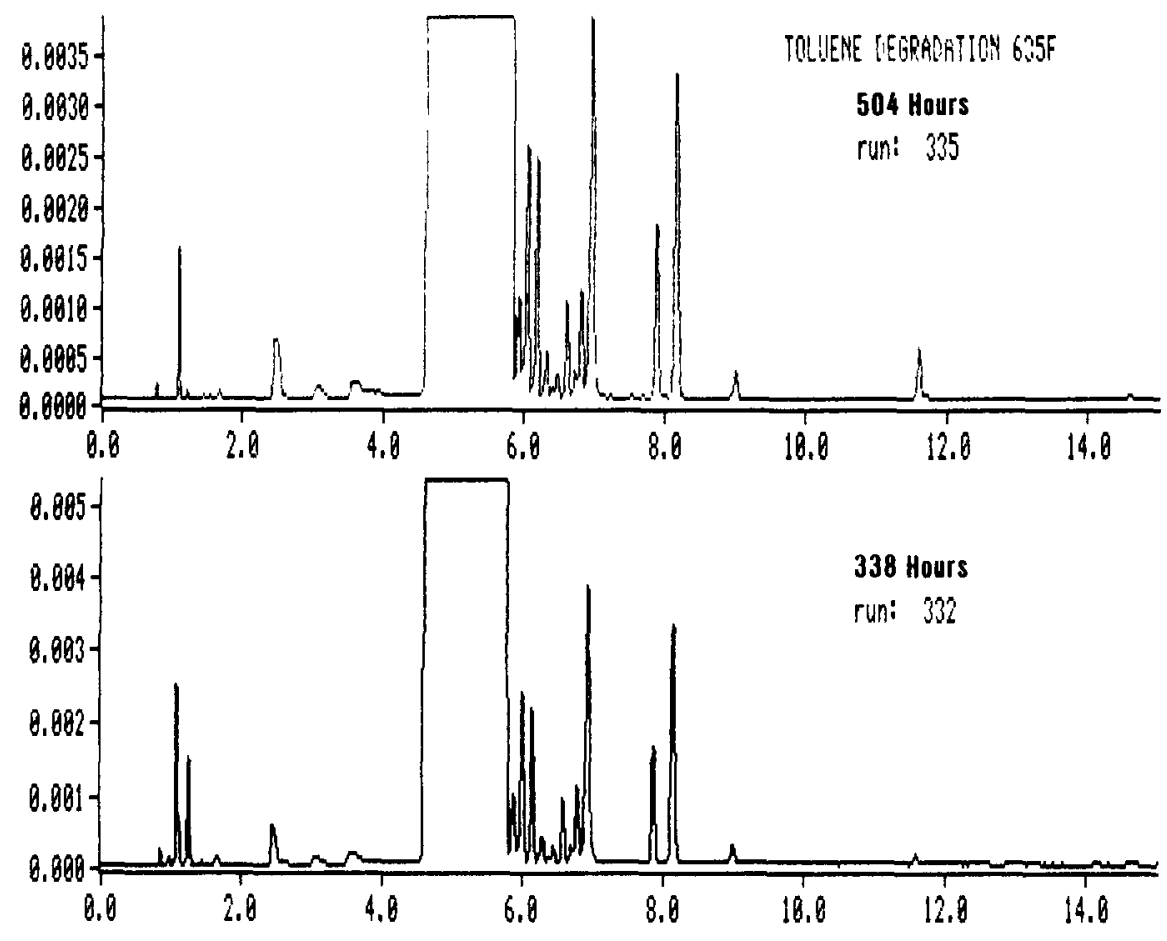

FIGURE C.6b Replotted Chromatograms for $635^{\circ} \mathrm{F}, 504$ and $338 \mathrm{~h}$, Runs 335 and 332, Time Segment $=$ 0-15 $\mathrm{min}-$ Toluene Impurities
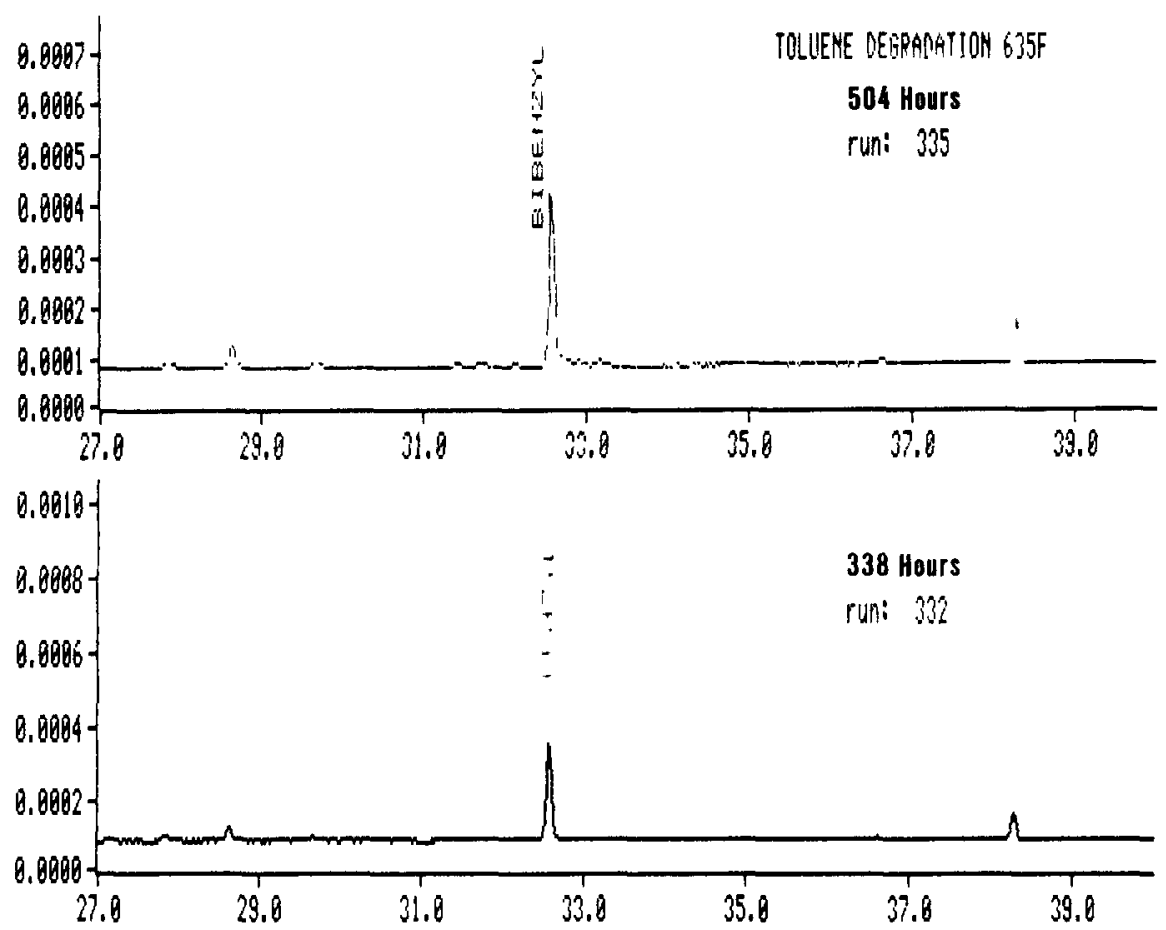

FIGURE C.6c Replotted Chromatograms for $635^{\circ} \mathrm{F}, 504$ and $338 \mathrm{~h}$, Runs 335 and 332, Time Segment $=$ 27-40 $\mathrm{min}-$ Degradation Products 


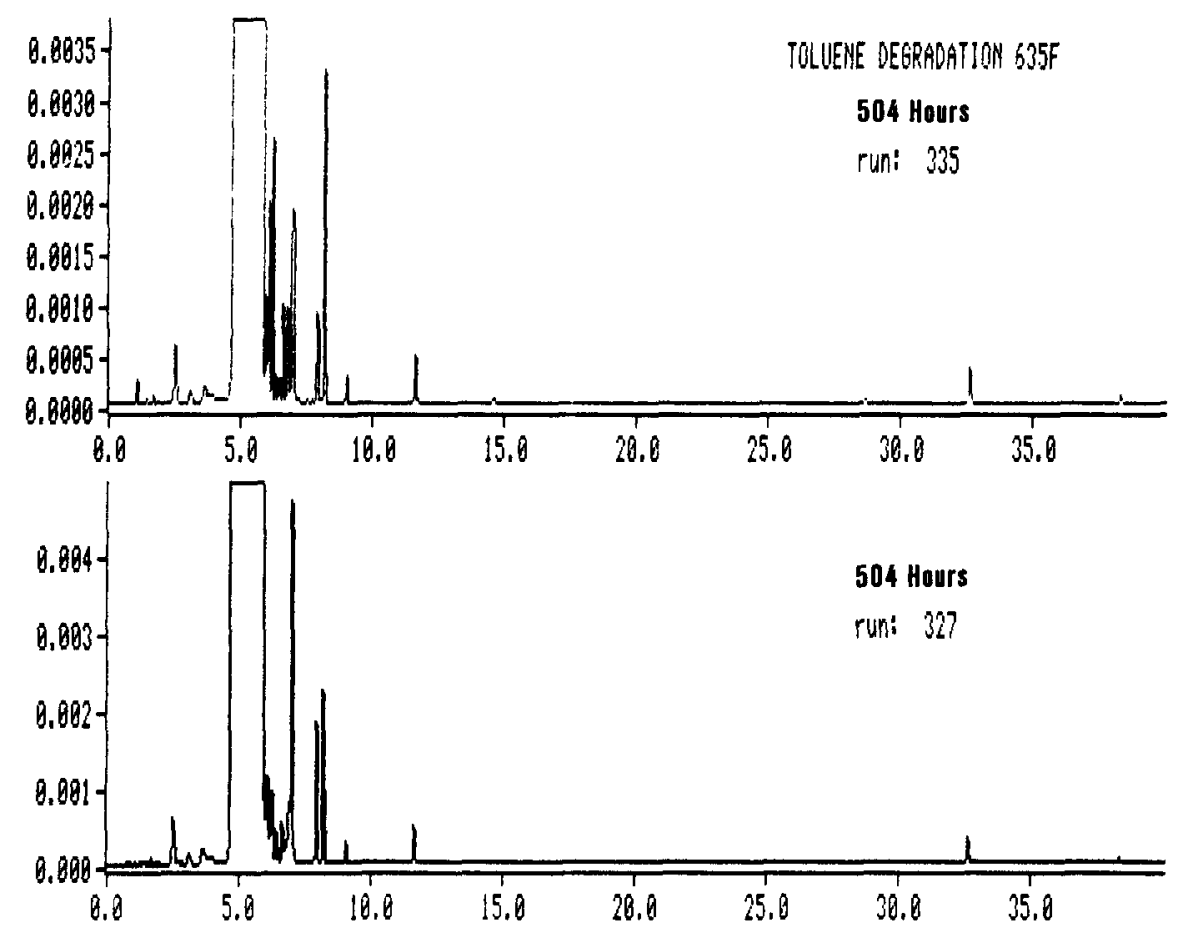

FIGURE C.7a Replotted Chromatograms for $635^{\circ} \mathrm{F}, 504 \mathrm{~h}$, Runs 335 and 327, Time Segment $=0-40 \mathrm{~min}$ - Total Degradation

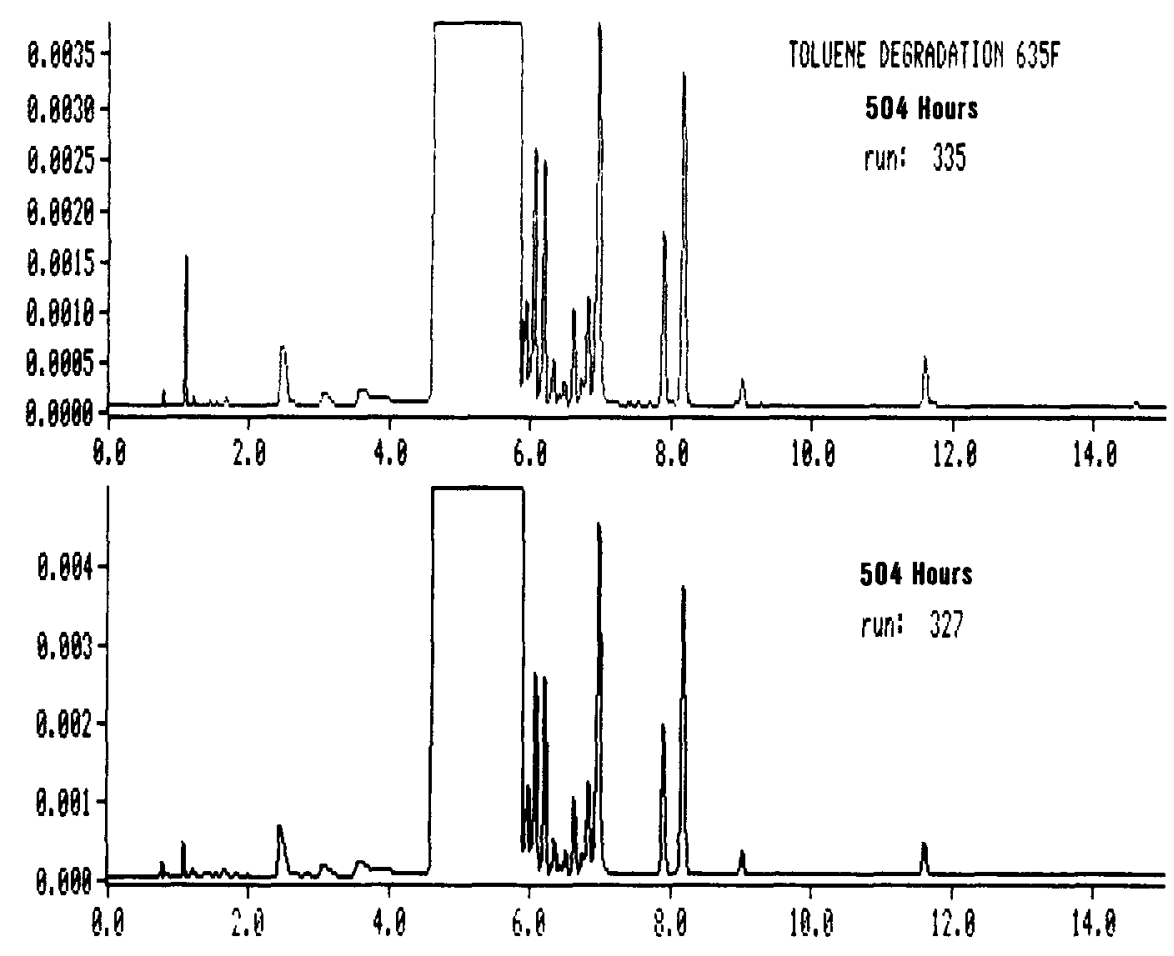

FIGURE C.7b Replotted Chromatograms for $635^{\circ} \mathrm{F}, 504 \mathrm{~h}$, Runs 335 and 327, Time Segment $=0-15 \mathrm{~min}-$ Toluene Impurities 

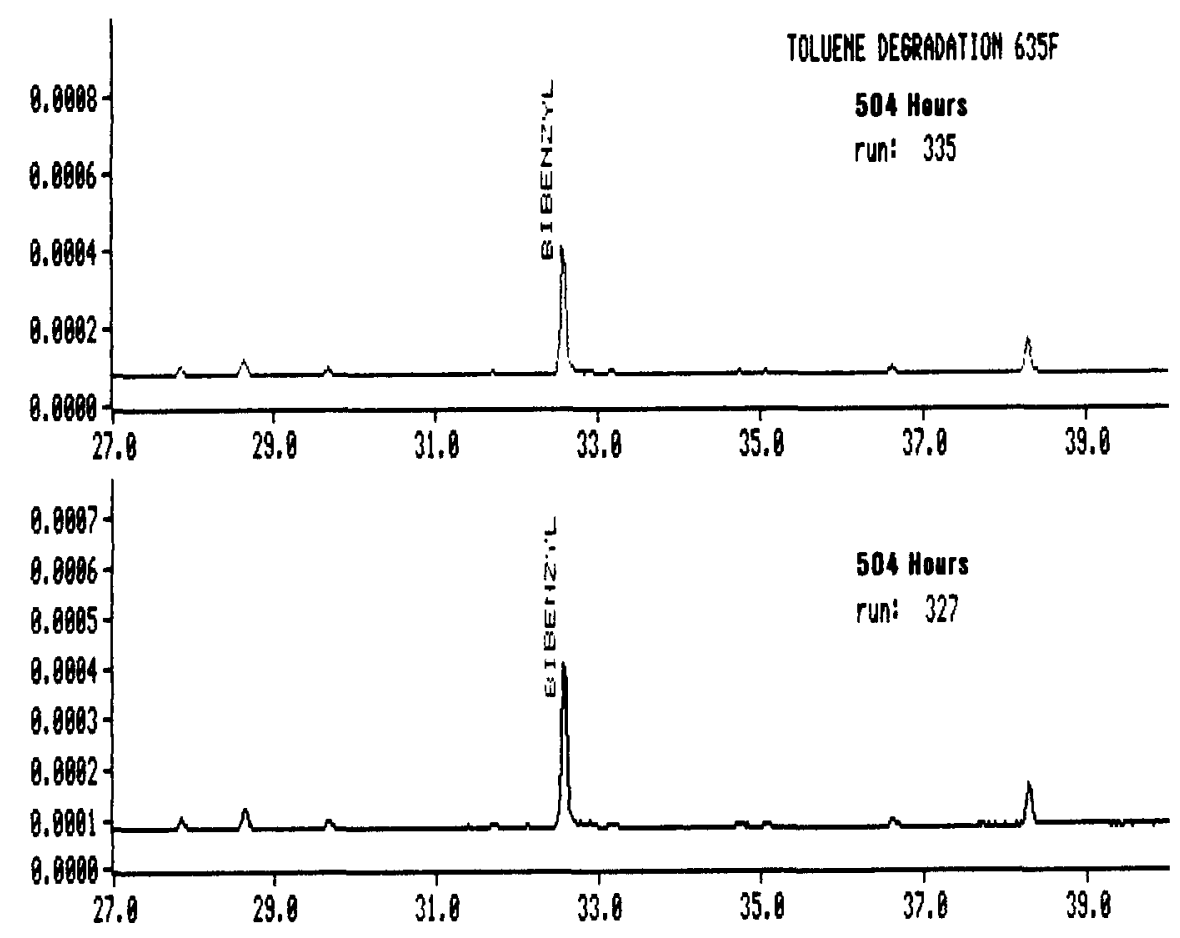

FIGURE C.7c Replotted Chromatograms for $635^{\circ} \mathrm{F}, 504 \mathrm{~h}$, Runs 335 and 327, Time Segment $=$ 27-40 min - Degraded Toluene Products

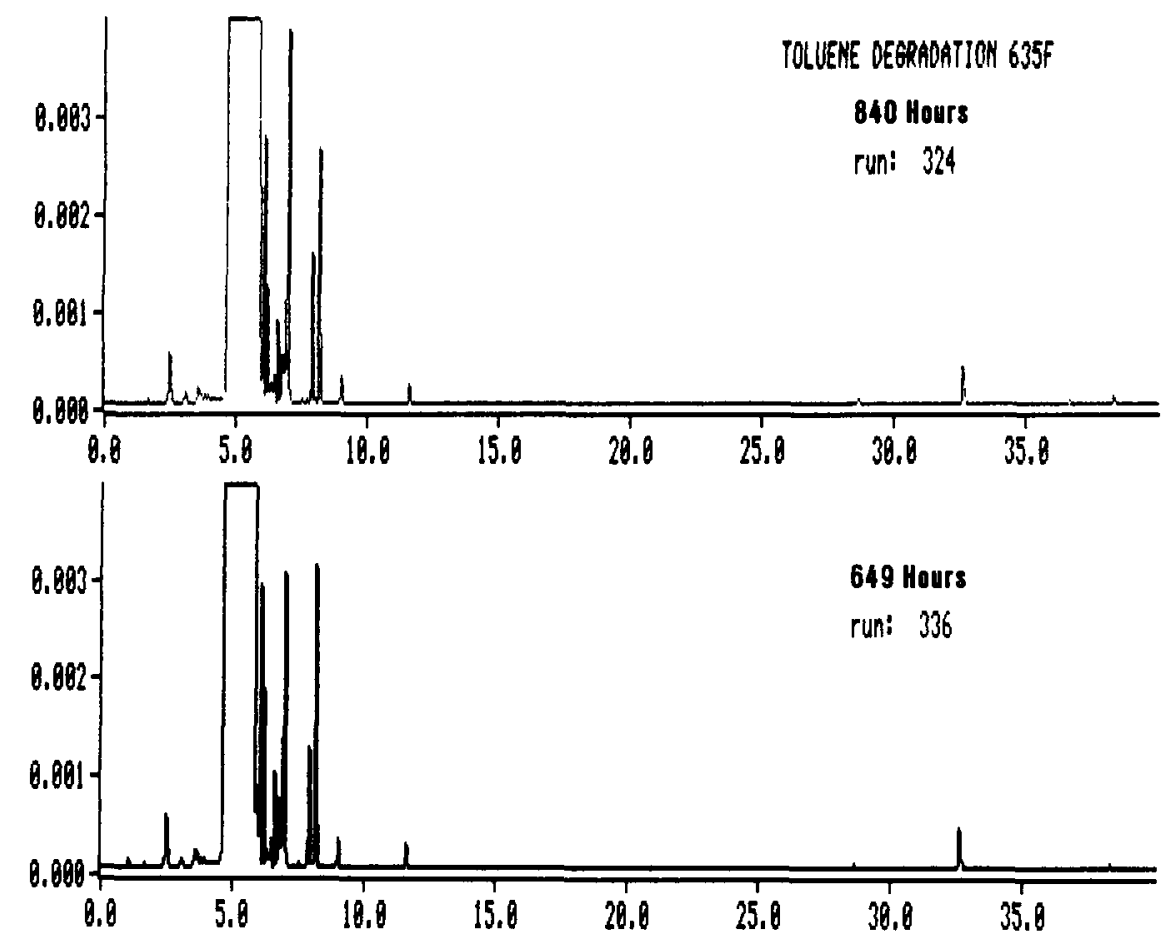

FIGURE C.8a Replotted Chromatograms for $635^{\circ} \mathrm{F}, 840$ and $649 \mathrm{~h}$, Runs 324 and 336, Time Segment = 0-40 min - Major Components 

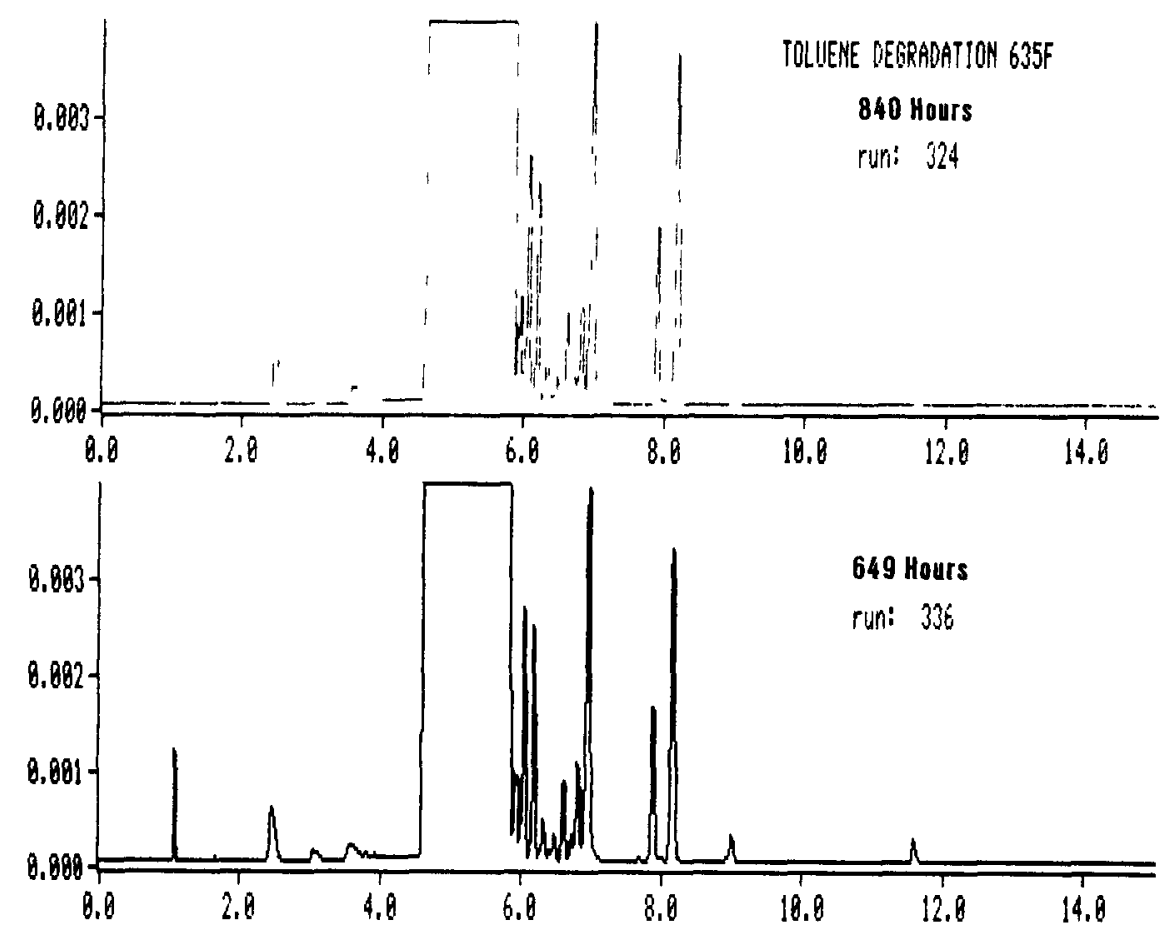

FIGURE C.8b Replotted Chromatograms for $635^{\circ} \mathrm{F}, 840$ and $649 \mathrm{~h}$, Runs 324 and 336, Time Segment $=0-15 \mathrm{~min}-$ Toluene Impurities

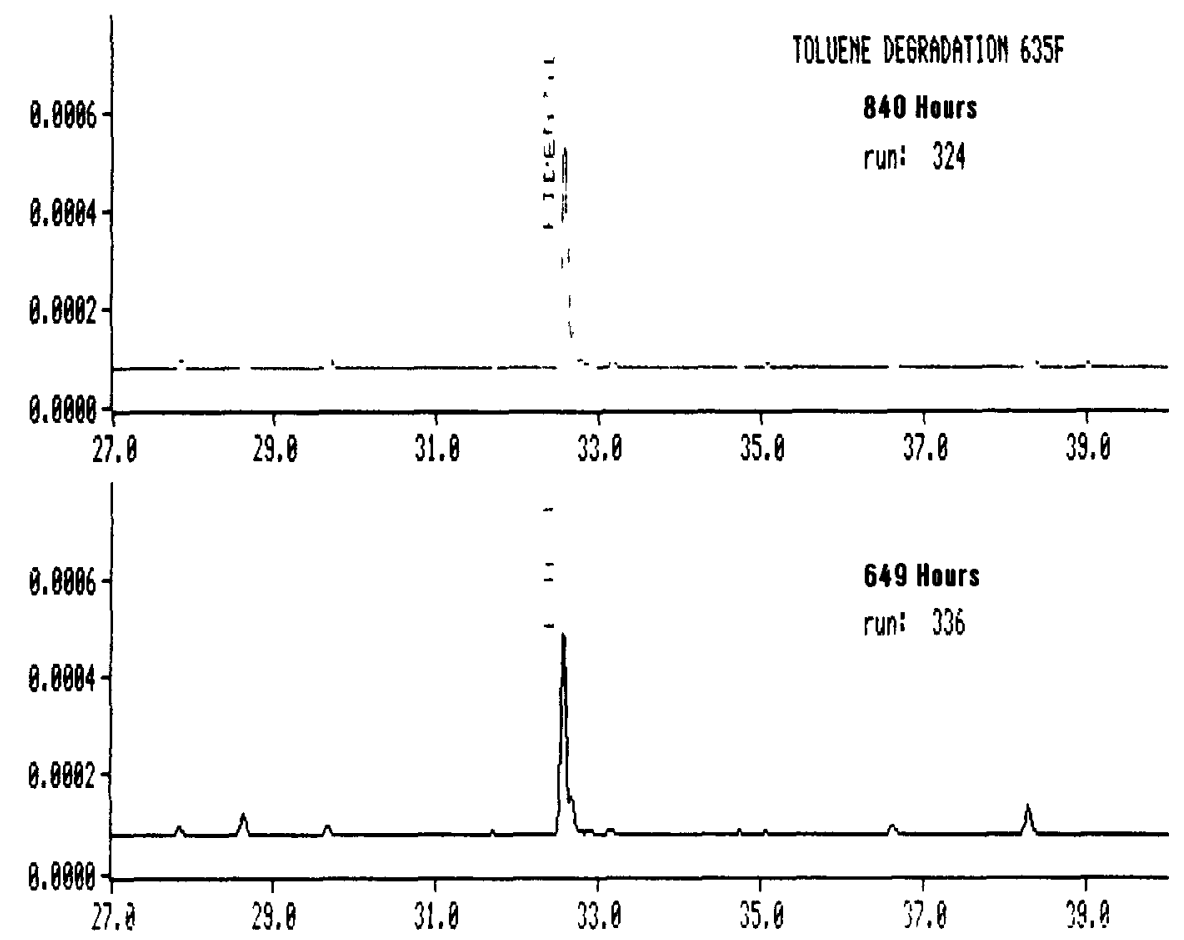

FIGURE C.8c Replotted Chromatograms for $635^{\circ} \mathrm{F}, 840$ and $649 \mathrm{~h}$, Runs 324 and 336, Time Segment $=27-40 \mathrm{~min}-$ Degradation Products 


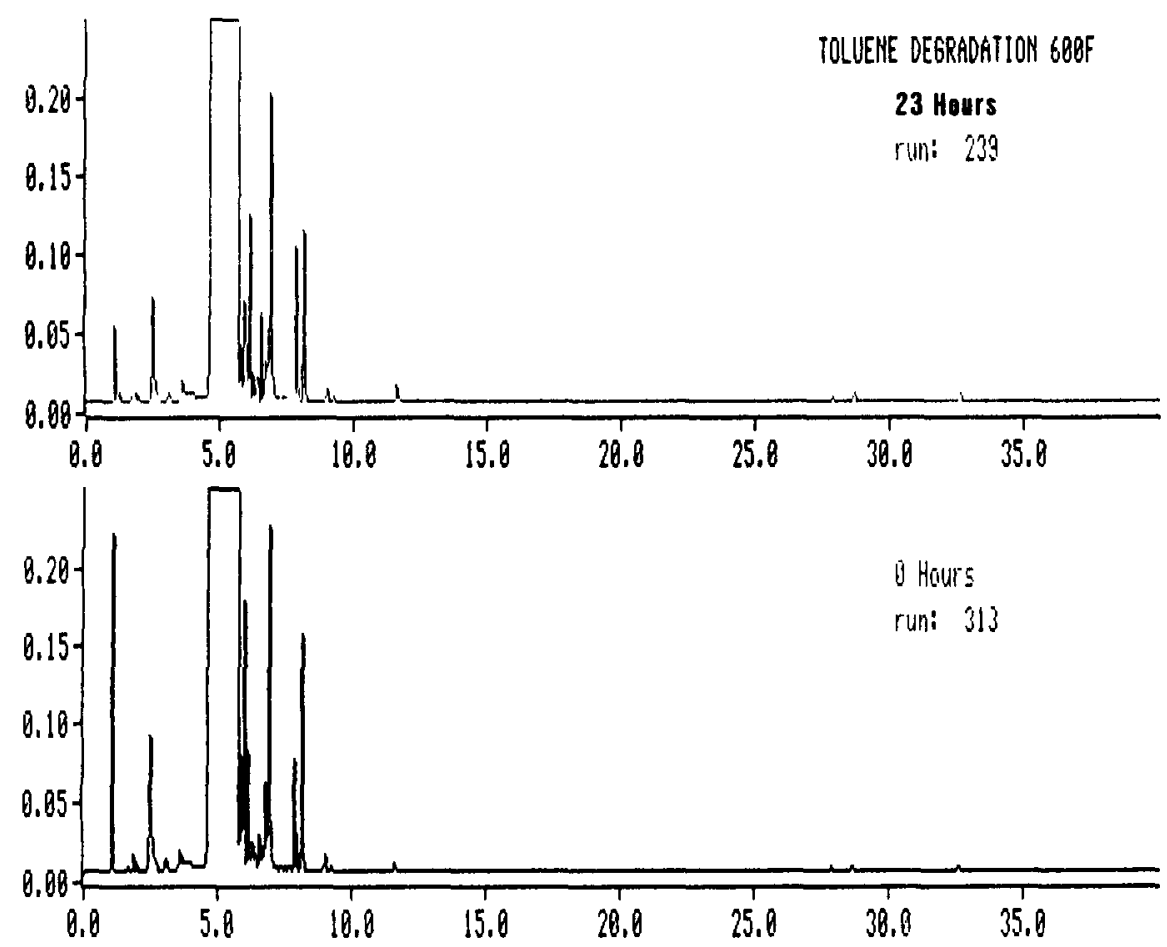

FIGURE C.9a Replotted Chromatograms for $600^{\circ} \mathrm{F}, 23$ and $0 \mathrm{~h}$, Runs 239 and 313, Time Segment $=$ 0-40 $\mathrm{min}-$ Major Components

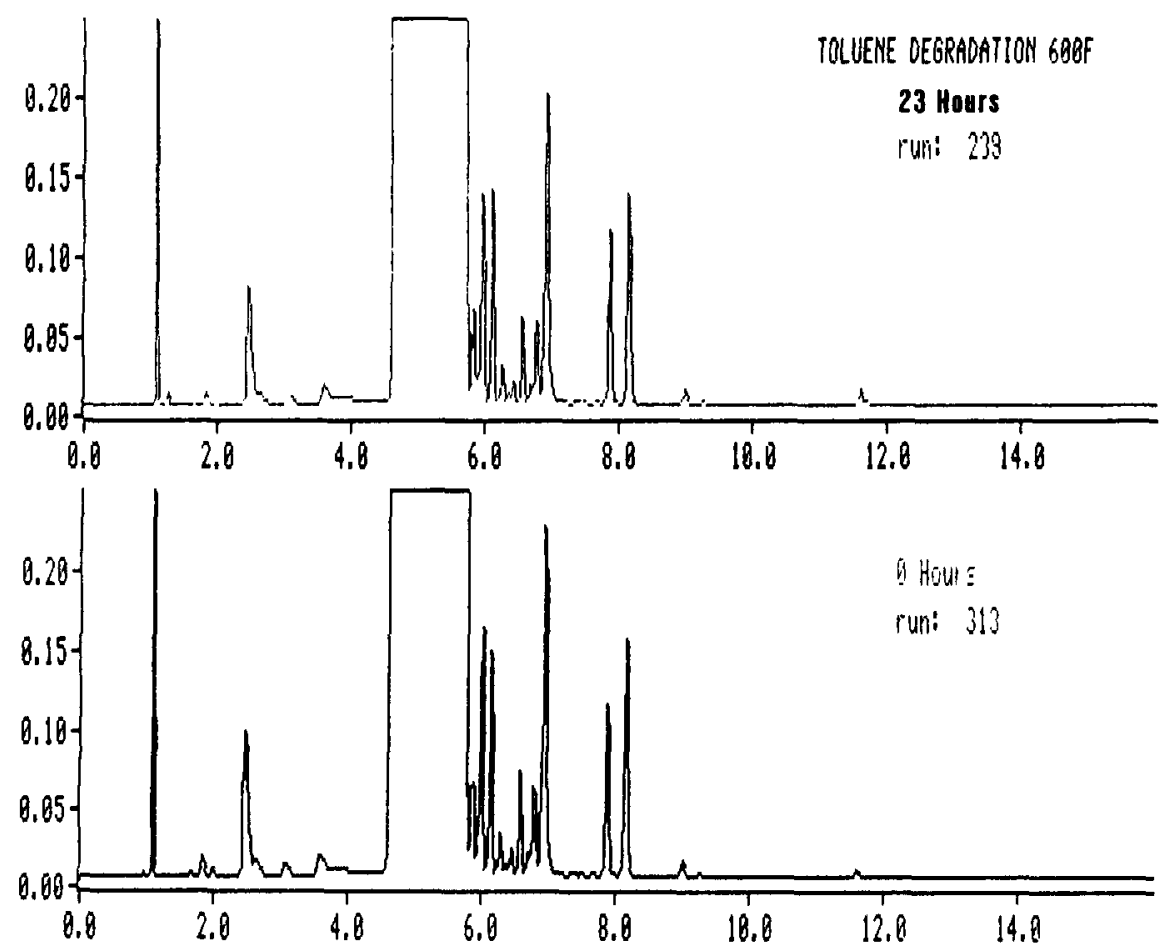

FIGURE C.9b Replotted Chromatograms for $600^{\circ} \mathrm{F}, 23$ and $0 \mathrm{~h}$, Runs 239 and 313, Time Segment $=0-15 \mathrm{~min}-$ Toluene Impurities 


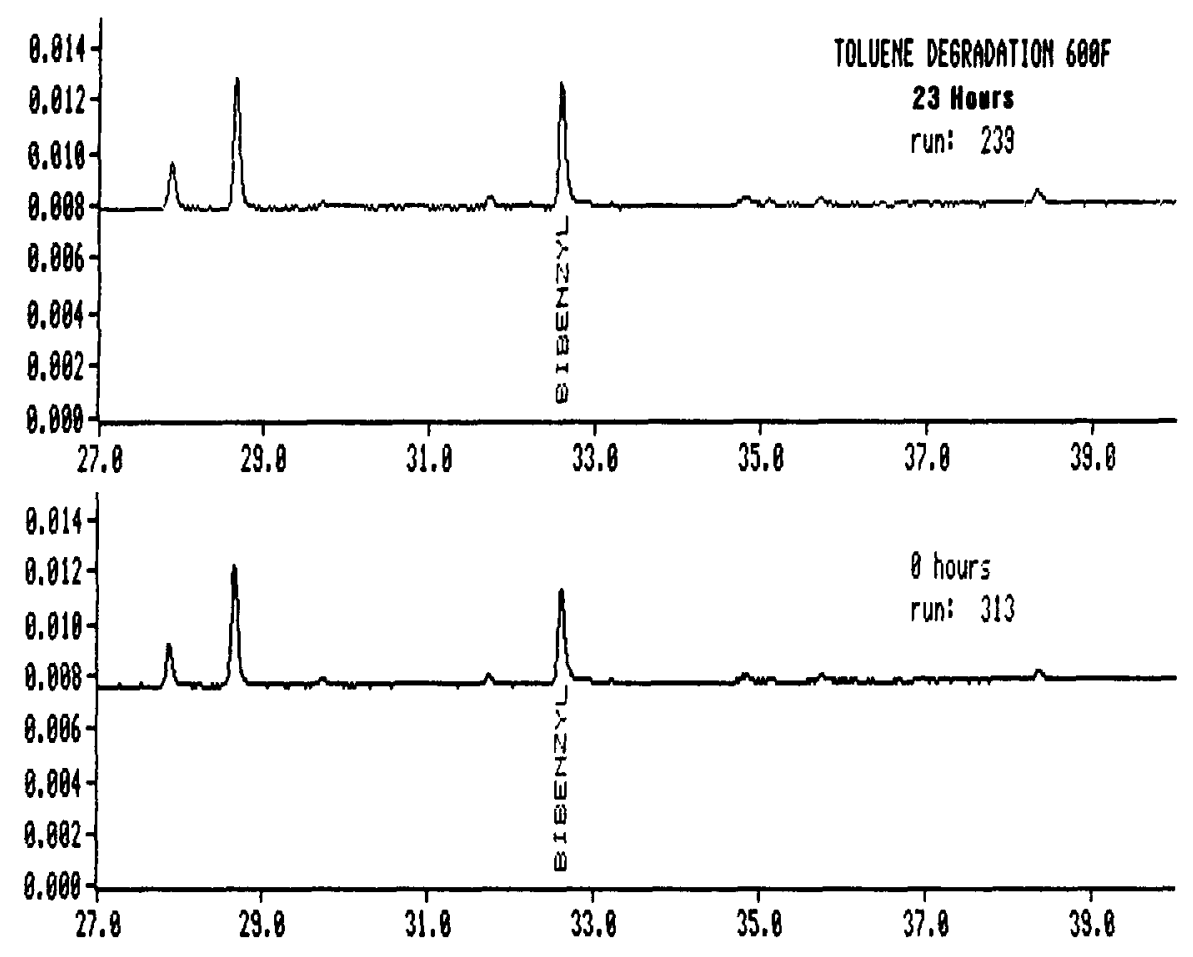

FIGURE C.9c Replotted Chromatograms for $600^{\circ} \mathrm{F}, 23$ and $0 \mathrm{~h}$, Runs 239 and 313, Time Segment $=27-40 \mathrm{~min}-$ Degradation Products

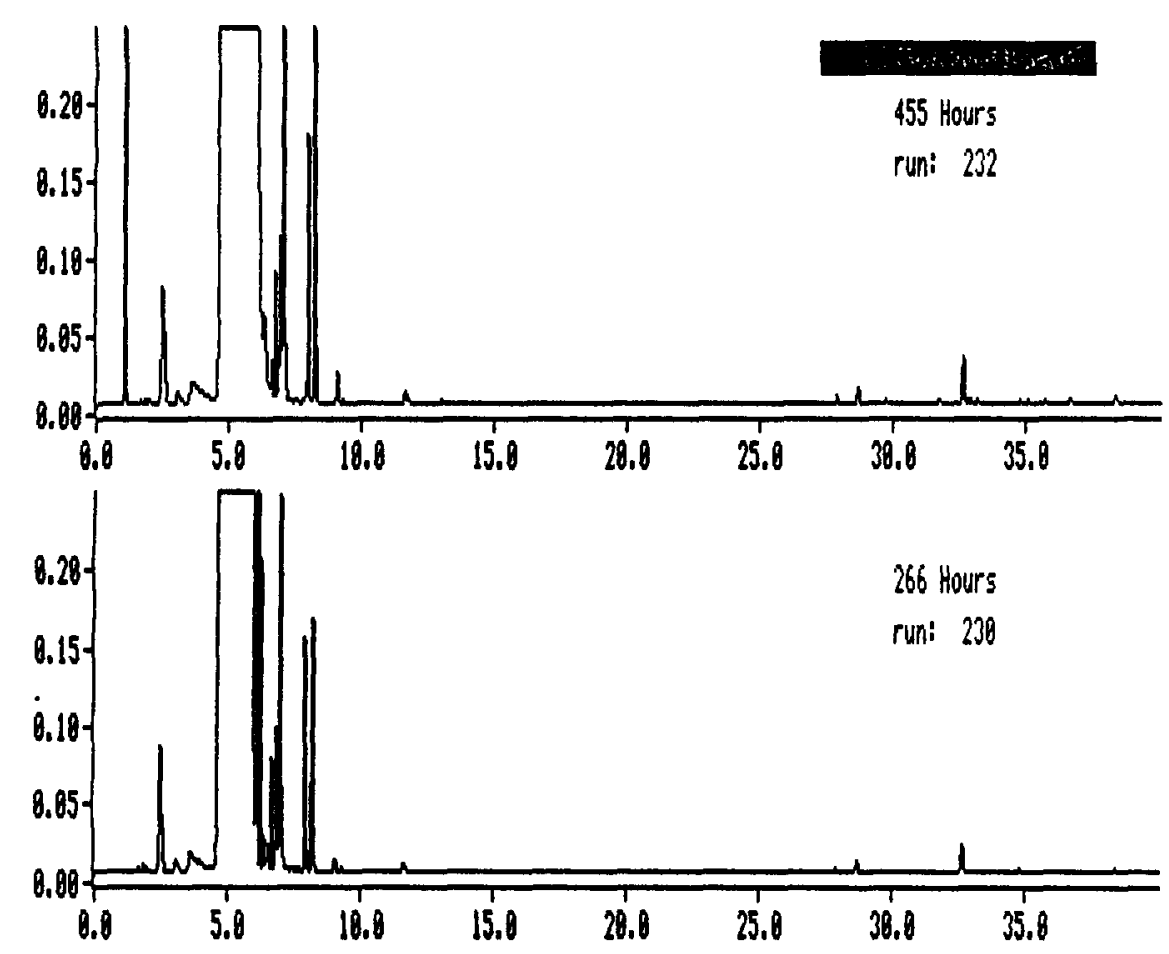

FIGURE C.10a Replotted Chromatograms for $600^{\circ} \mathrm{F}, 455$ and $266 \mathrm{~h}$, Runs 232 and 230, Time Segment $=$ 0-40 min - Major Components 

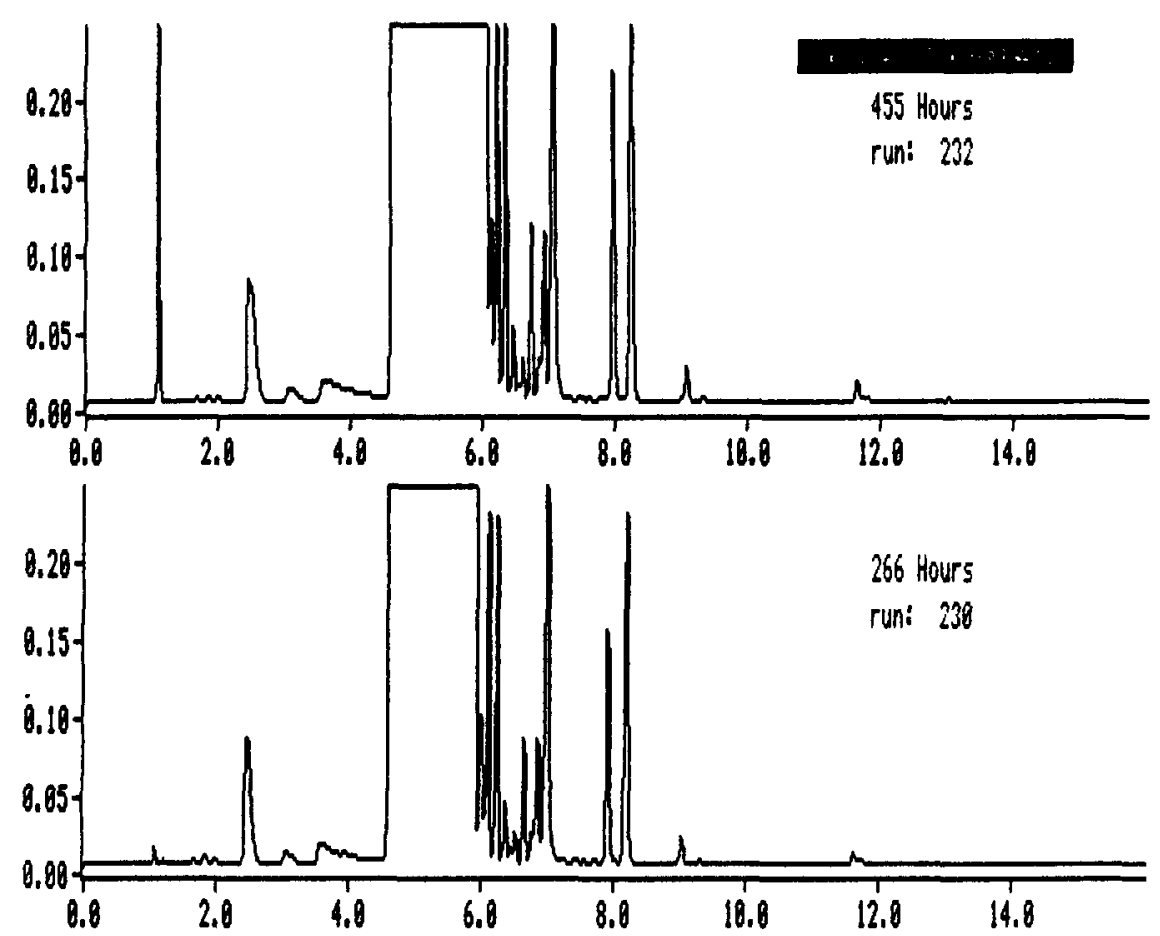

FIGURE C.10b Replotted Chromatograms for $600^{\circ} \mathrm{F}, 455$ and $266 \mathrm{~h}$, Runs 232 and 230, Time Segment $=0$-15 $\mathrm{min}-$ Toluene Impurities

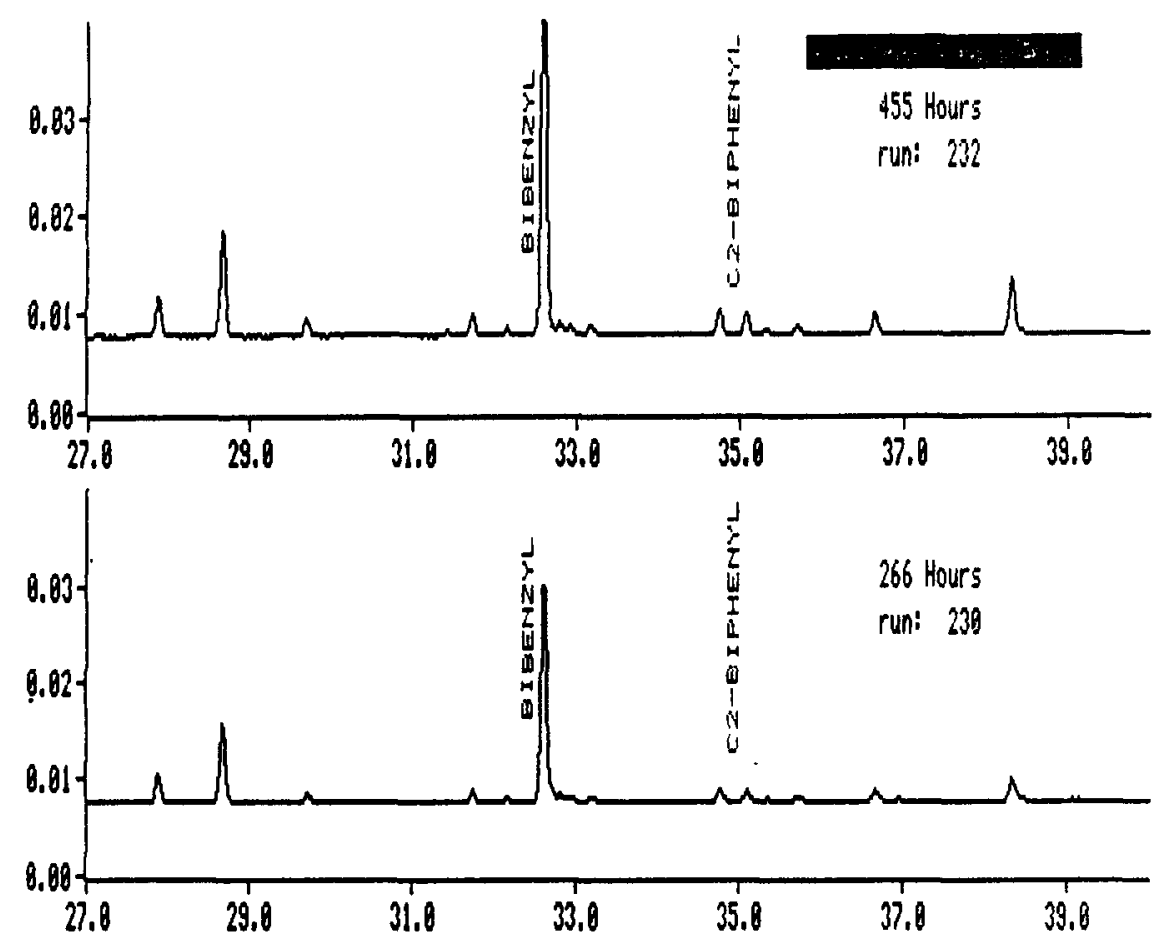

FIGURE C.10c Replotted Chromatograms for $600^{\circ} \mathrm{F}, 455$ and $266 \mathrm{~h}$, Runs 232 and 230, Time Segment $=$ 27-40 $\mathrm{min}-$ Degradation Products 


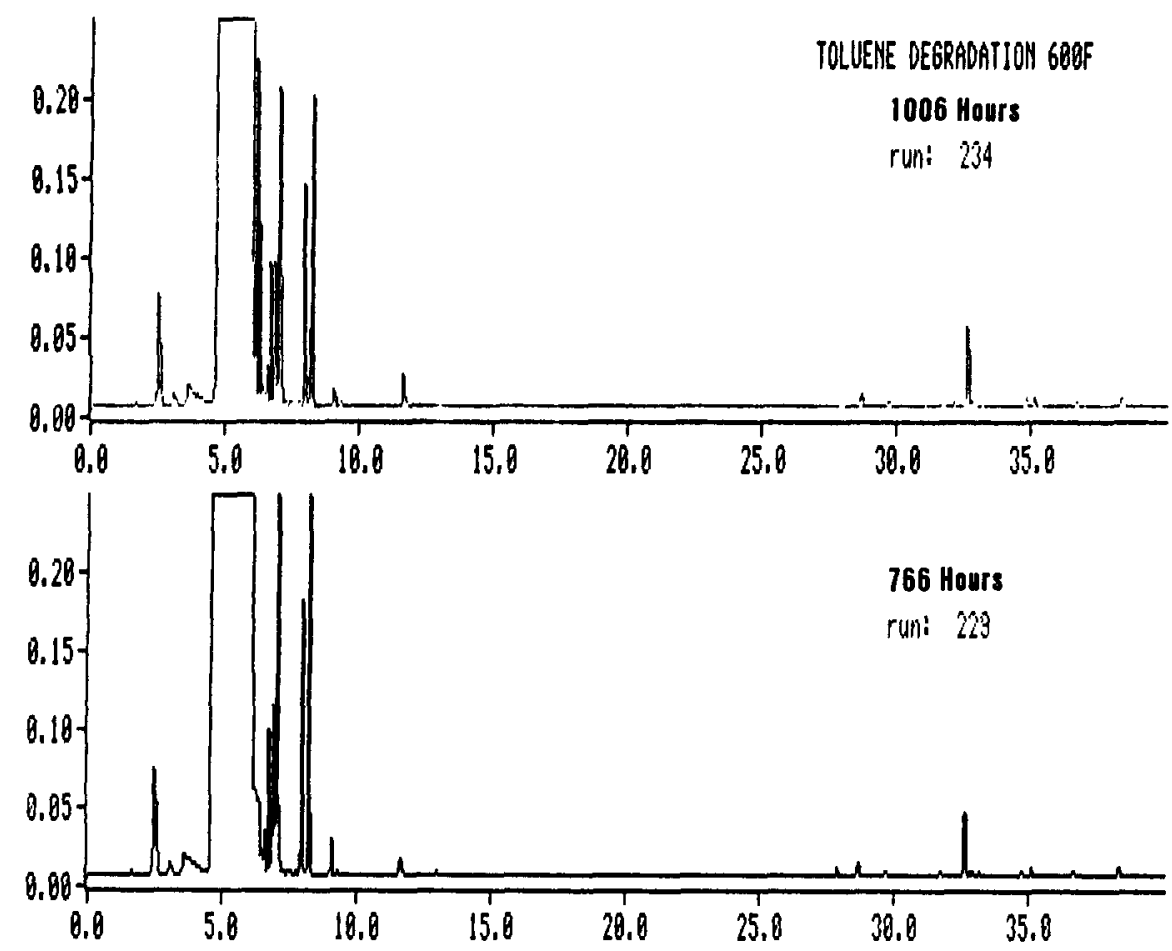

FIGURE C.11a Replotted Chromatograms for $600^{\circ} \mathrm{F}, 1006$ and $766 \mathrm{~h}$, Runs 234 and 229, Time Segment $=0-40$ min - Major Components

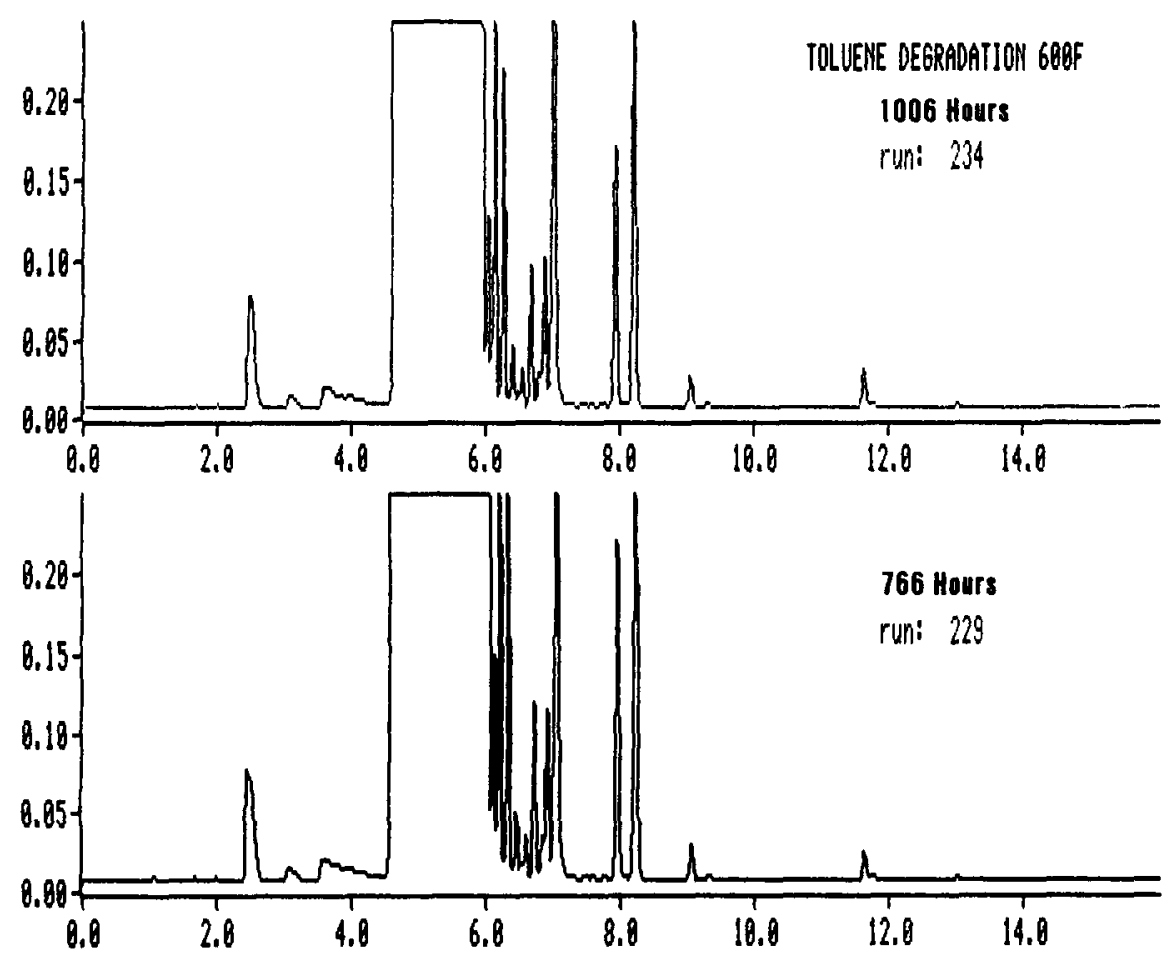

FIGURE C.11b Replotted Chromatograms for $600^{\circ} \mathrm{F}, 1006$ and $766 \mathrm{~h}$, Runs 234 and 229, Time Segment $=0-15 \mathrm{~min}-$ Toluene Impurities 


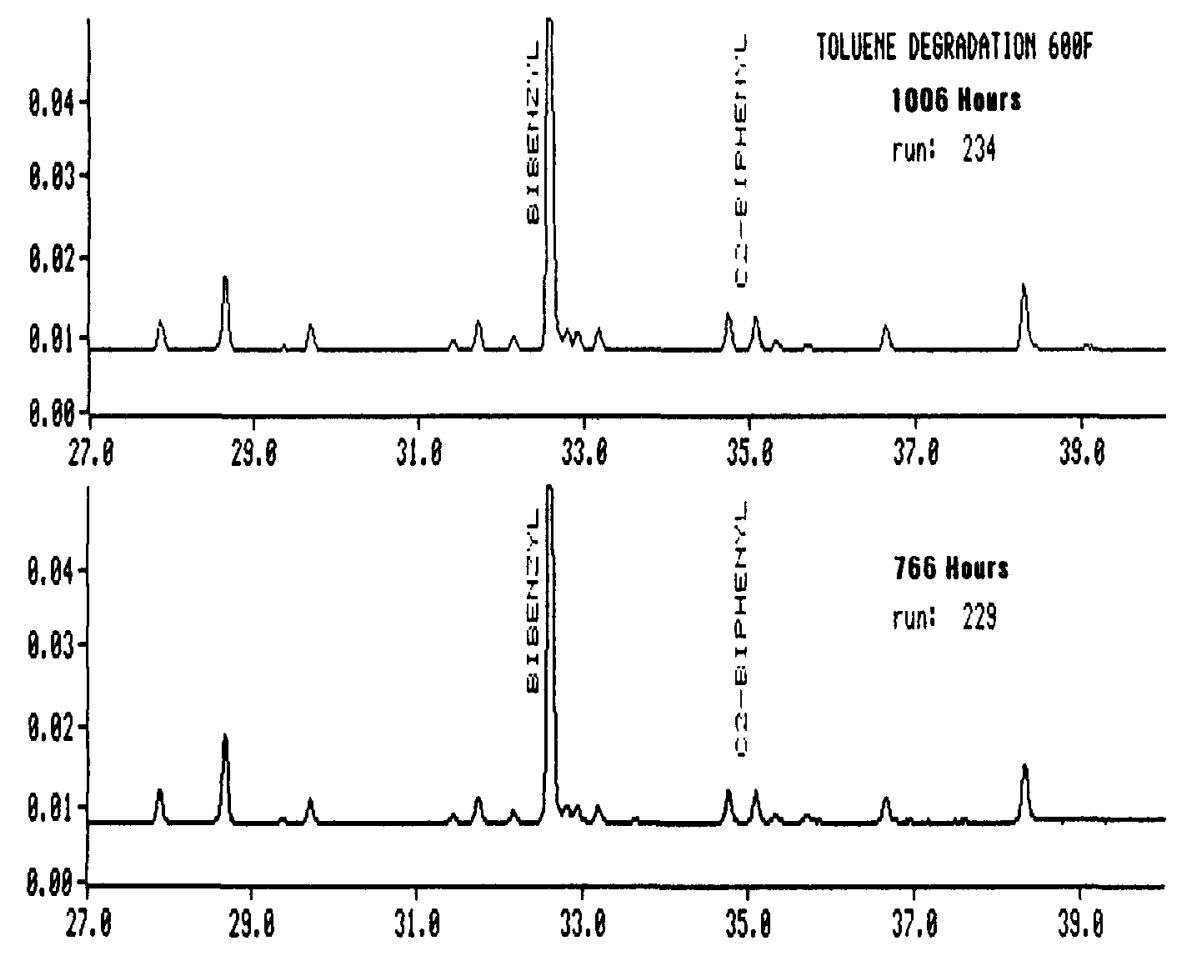

FIGURE C.11c Replotted Chromatograms for $600^{\circ} \mathrm{F}, 1006$ and $766 \mathrm{~h}$, Runs 234 and 229, Time Segment $=$ 27-40 $\mathrm{min}-$ Degradation Products
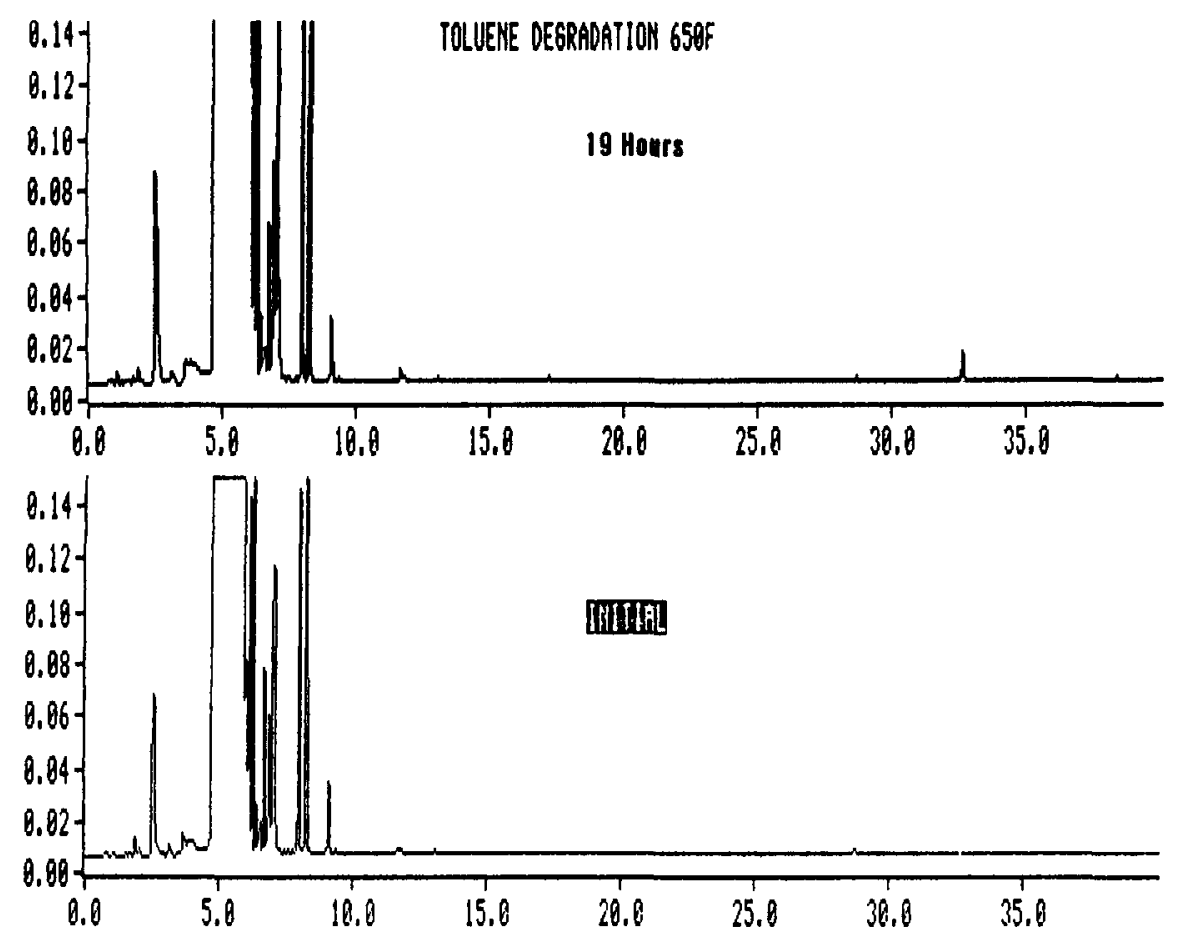

FIGURE C.12a Replotted Chromatograms for $650^{\circ} \mathrm{F}, 19$ and $0 \mathrm{~h}$, Time Segment = 0-40 min - Major Components 

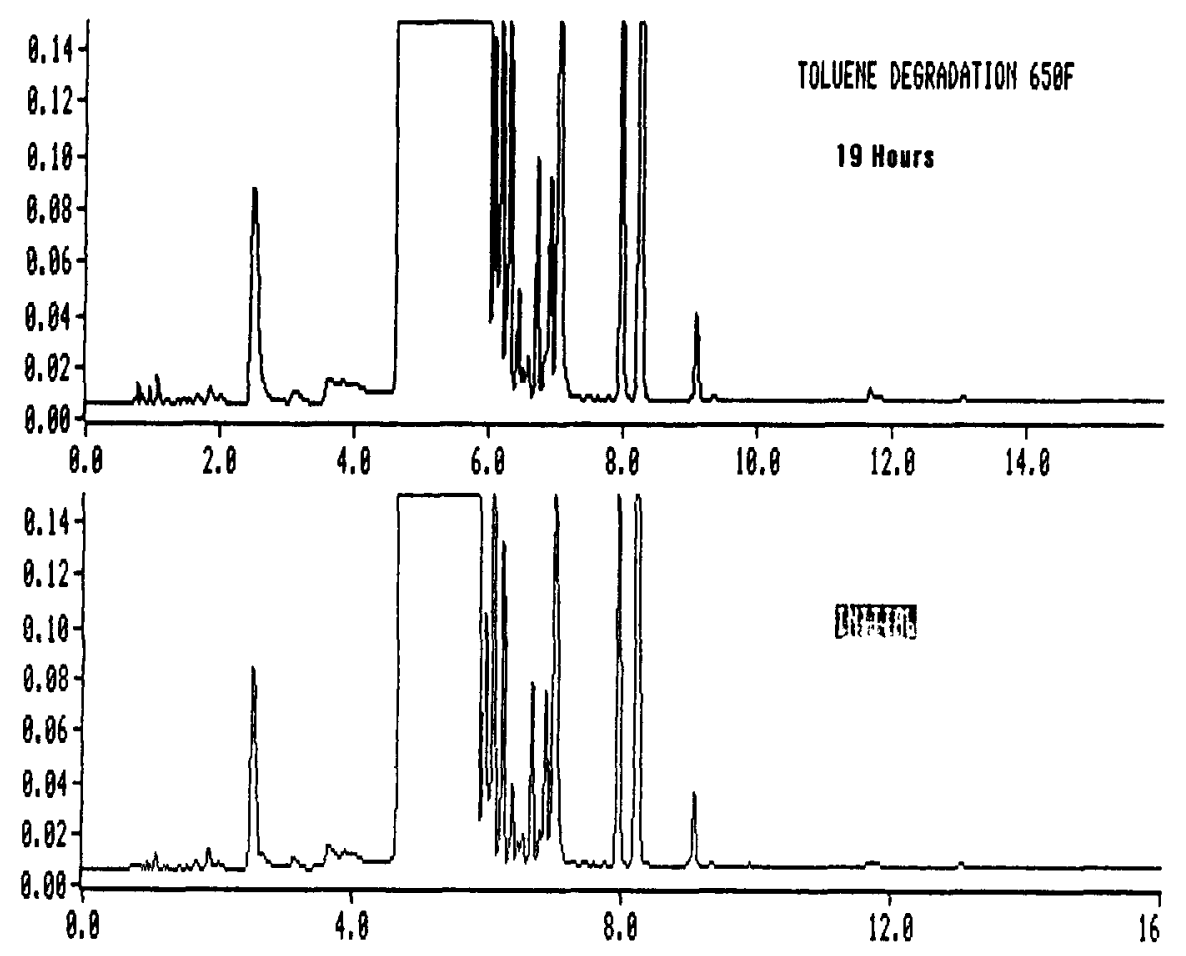

FIGURE C.12b Replotted Chromatograms for $650^{\circ} \mathrm{F}, 19$ and $0 \mathrm{~h}$, Time Segment $=$ 0-15 $\mathrm{min}$ - Toluene Impurities
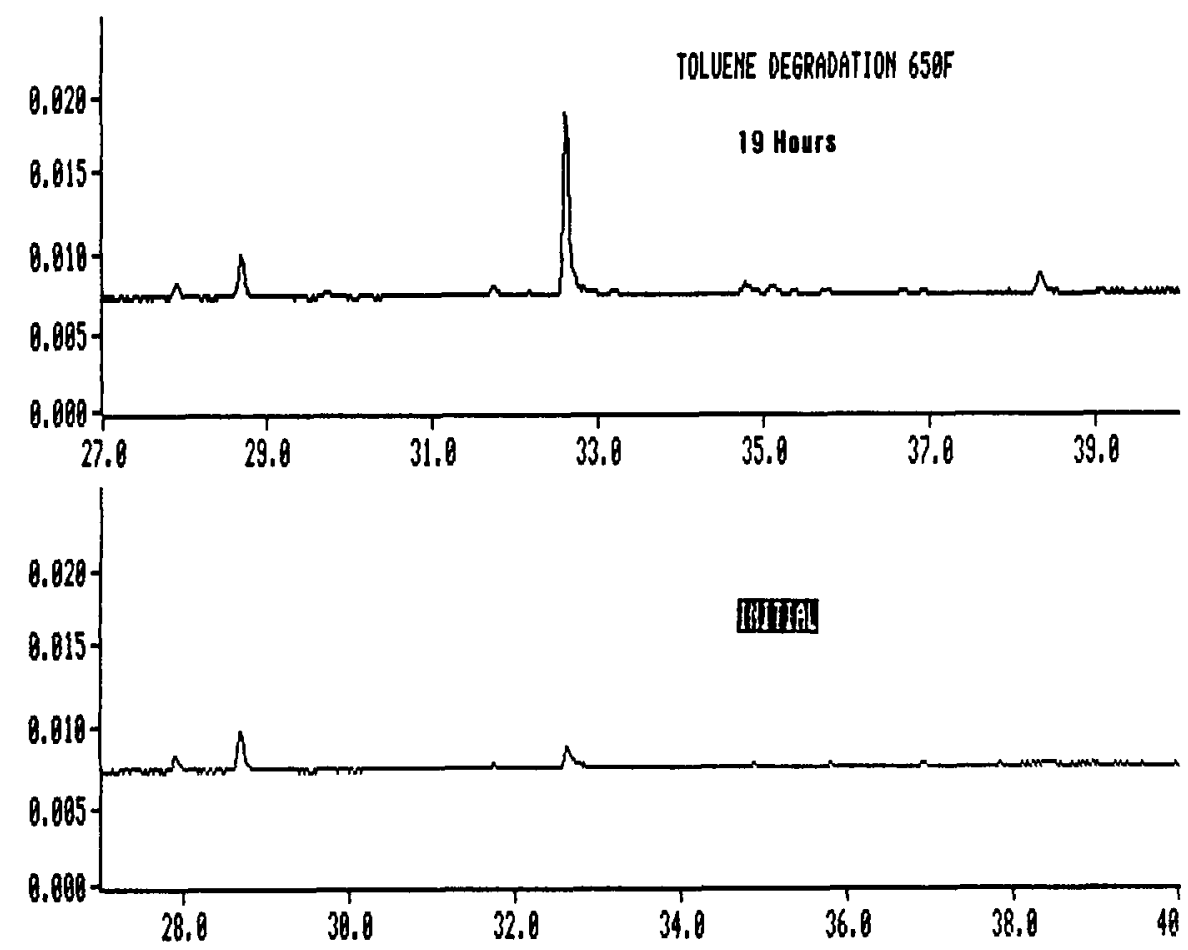

FIGURE C.12c Replotted Chromatograms for $650^{\circ} \mathrm{F}, 19$ and $0 \mathrm{~h}$, Time Segment $=$ 27-40 $\mathrm{min}-$ Degradation Products 


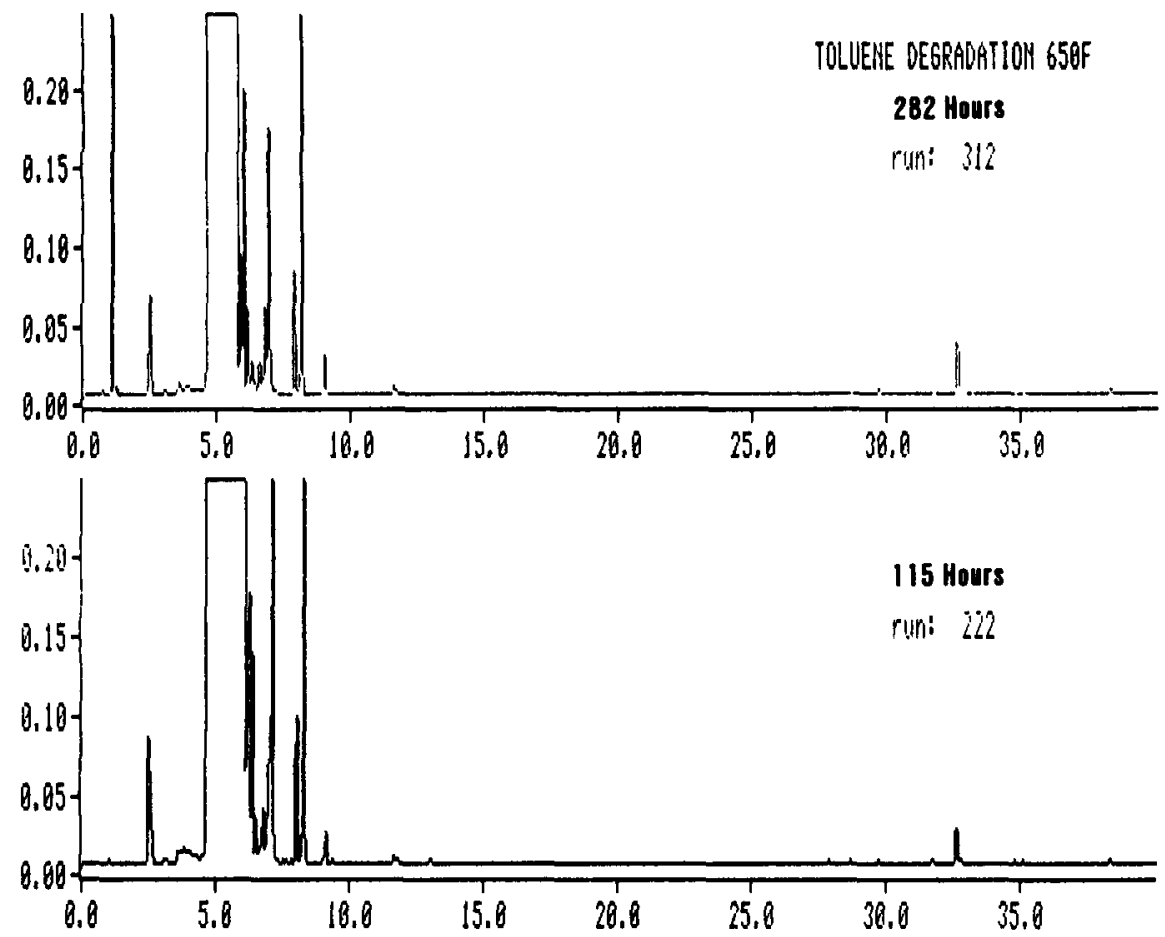

FIGURE C.13a Replotted Chromatograms for $650^{\circ} \mathrm{F}, 282$ and $115 \mathrm{~h}$, Runs 312 and 222, Time Segment = 0-40 $\mathrm{min}-$ Major Components

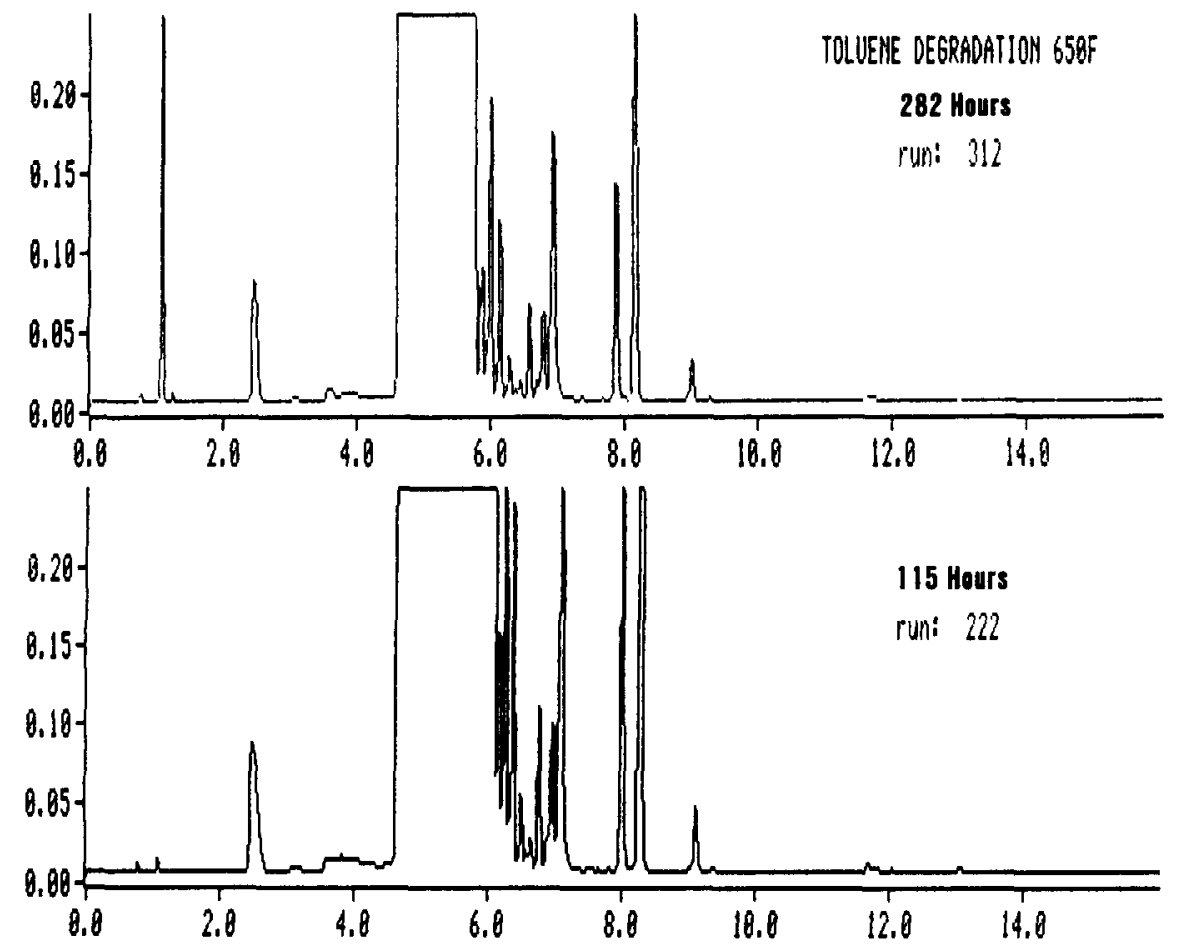

FIGURE C.13b Replotted Chromatograms for $650^{\circ} \mathrm{F}, 282$ and $115 \mathrm{~h}$, Runs 312 and 222, Time Segment $=0-15 \mathrm{~min}-$ Tolvene Impurities 

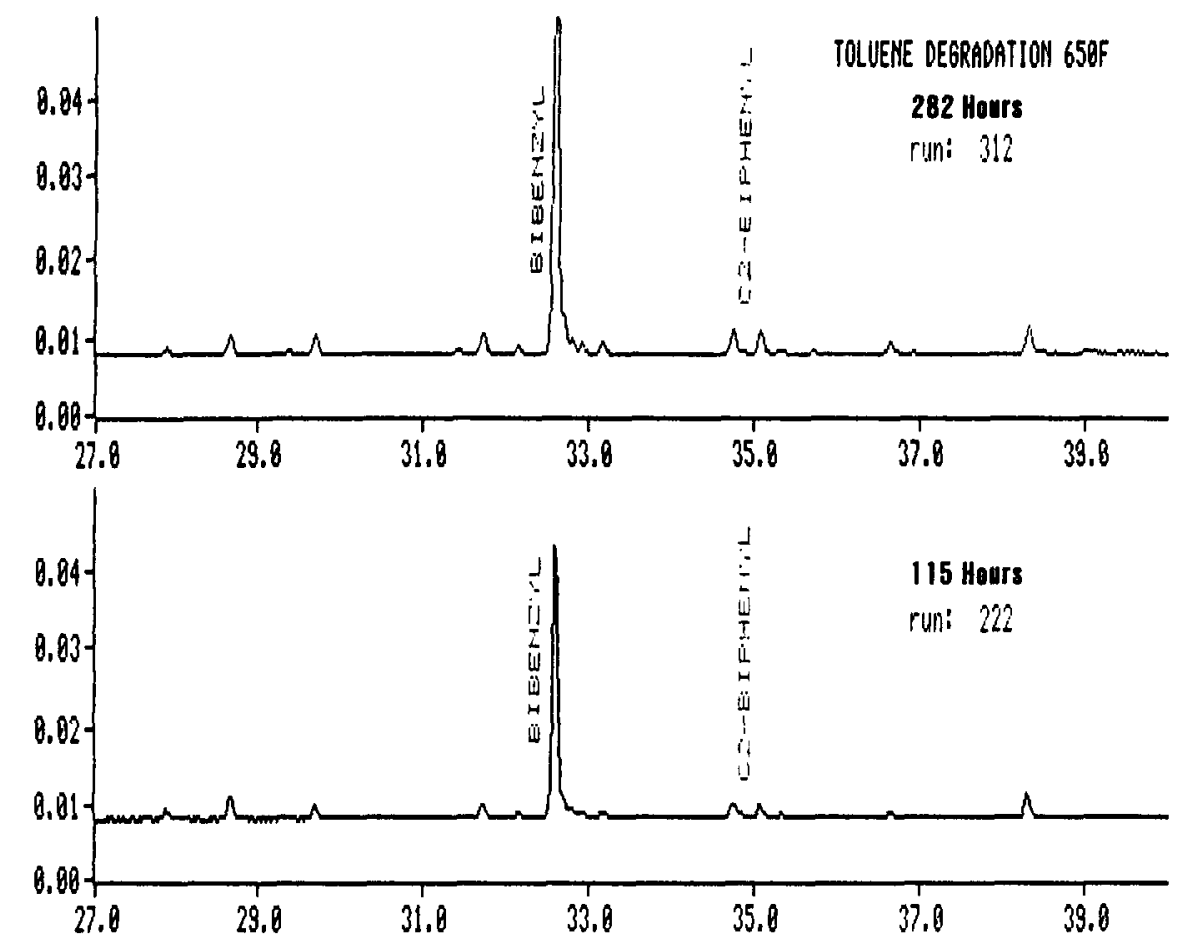

FIGURE C.13c Replotted Chromatograms for $650^{\circ} \mathrm{F}, 282$ and $115 \mathrm{~h}$, Runs 312 and 222, Time Segment $=27-40 \mathrm{~min}-$ Degradation Products

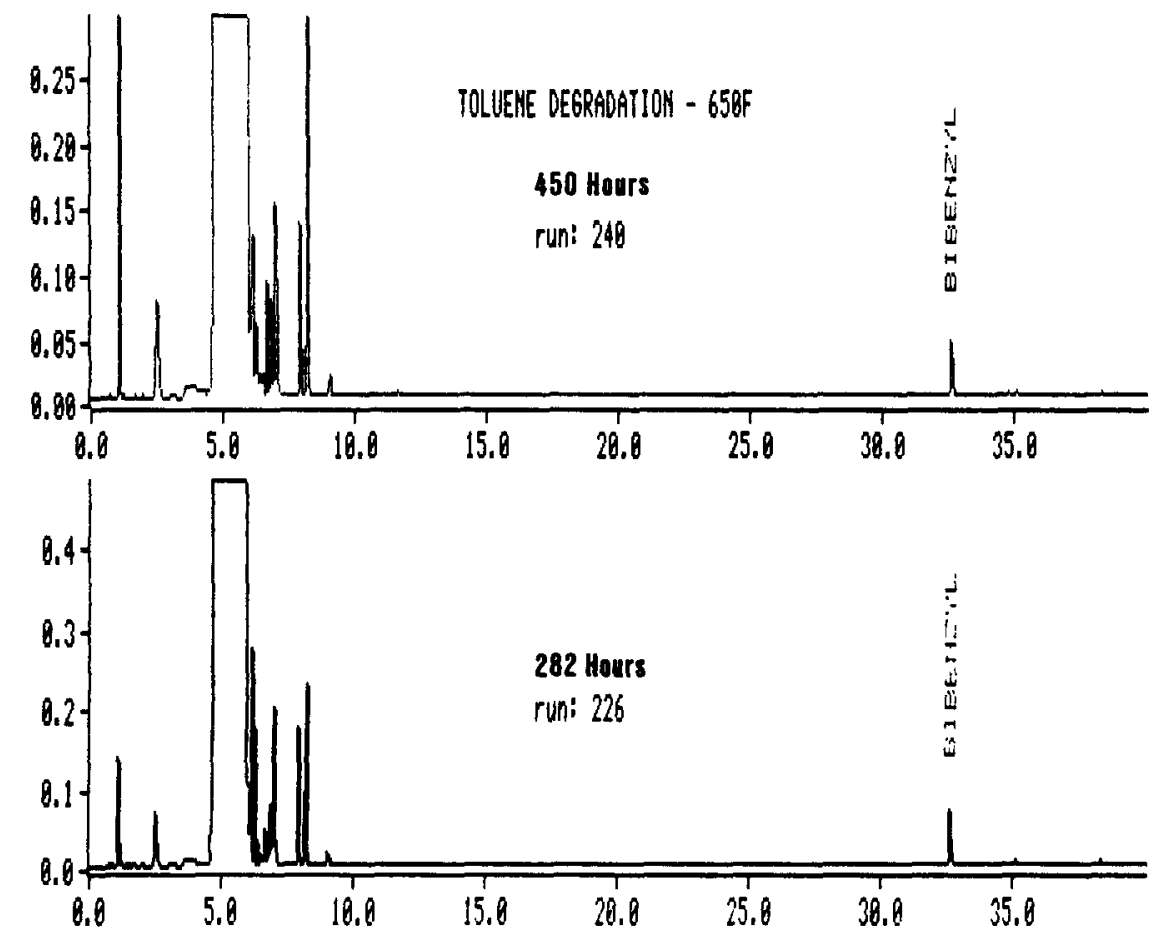

FIGURE C.14a Replotted Chromatograms for $650^{\circ} \mathrm{F}, 450$ and $282 \mathrm{~h}$, Runs 240 and 226, Time Segment $=0-40 \mathrm{~min}-$ Major Components 


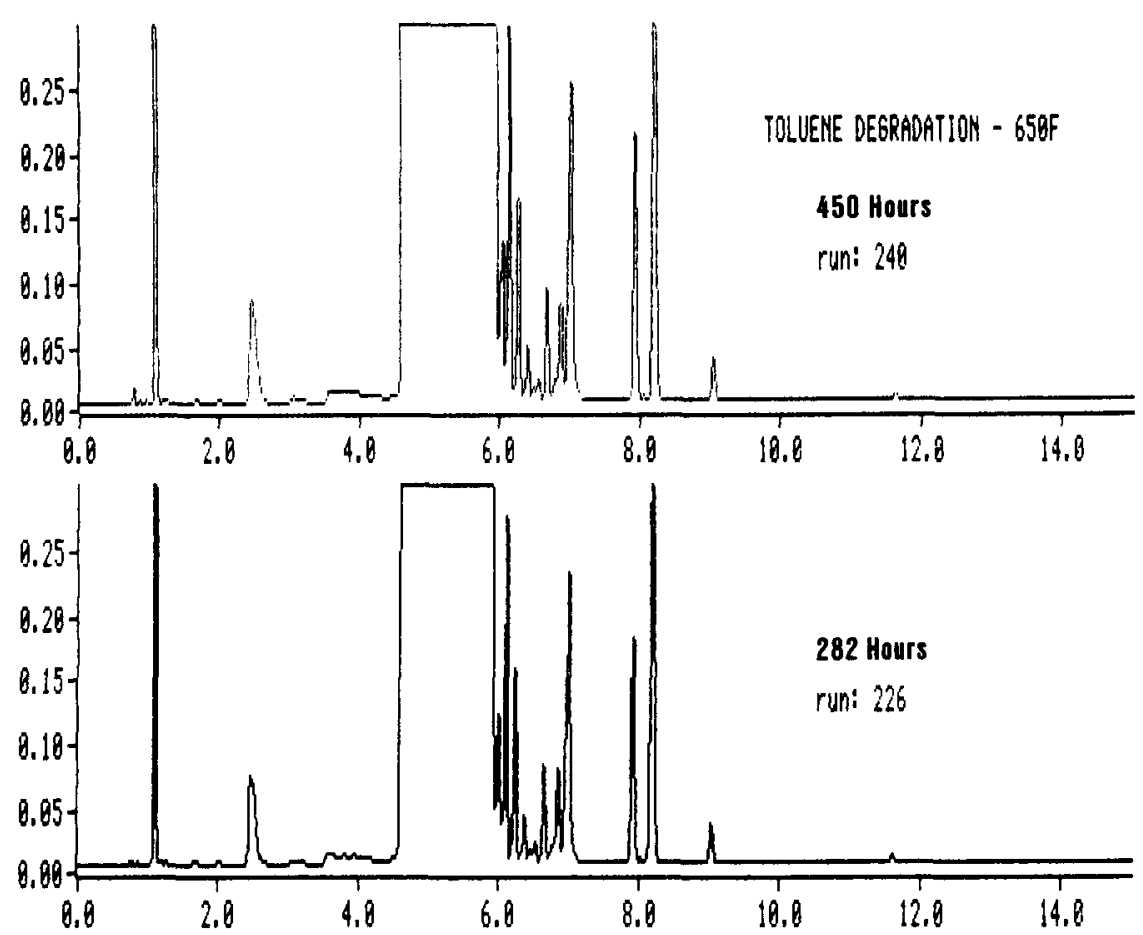

FIGURE C.14b Replotted Chromatograms for $650^{\circ} \mathrm{F}, 450$ and $282 \mathrm{~h}$, Runs 240 and 226, Time Segment $=0-15 \mathrm{~min}-$ Toluene Impurities
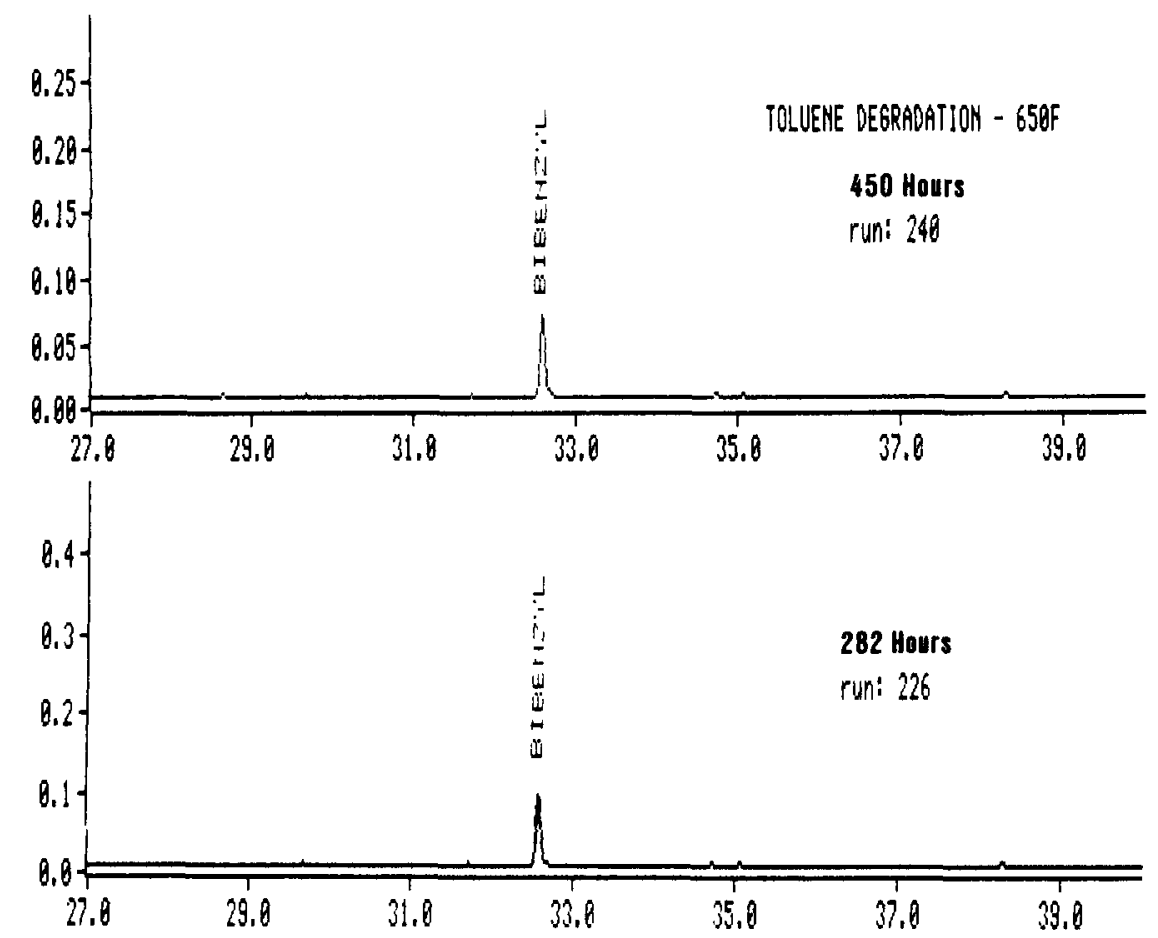

FIGURE C.14c Replotted Chromatograms for $650^{\circ} \mathrm{F}, 450$ and $282 \mathrm{~h}$, Runs 240 and 226, Time Segment $=27-40 \mathrm{~min}-$ Degradation Products 


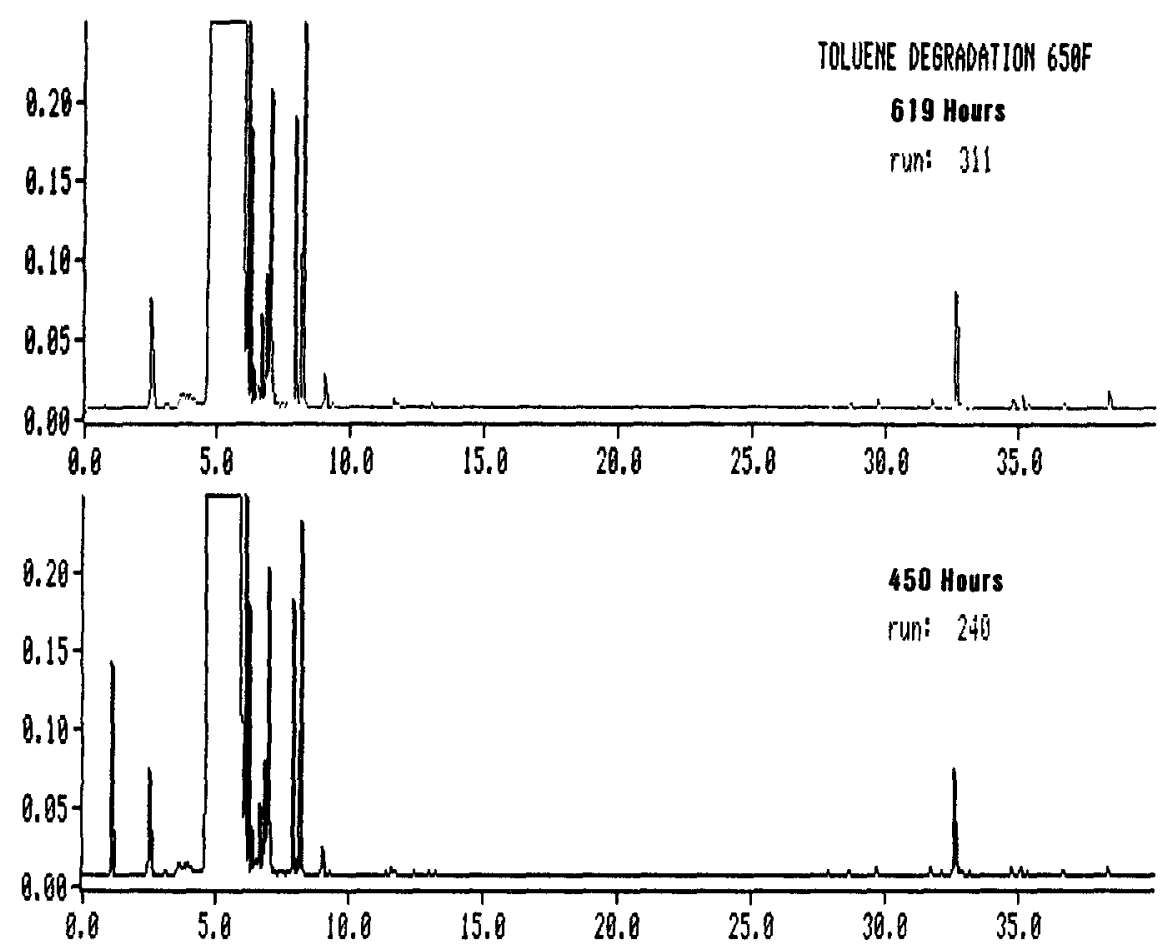

FIGURE C.15a Replotted Chromatograms for $650^{\circ} \mathrm{F}, 619$ and $450 \mathrm{~h}$, Runs 311 and 240, Time Segment $=0-40 \mathrm{~min}-$ Major Components

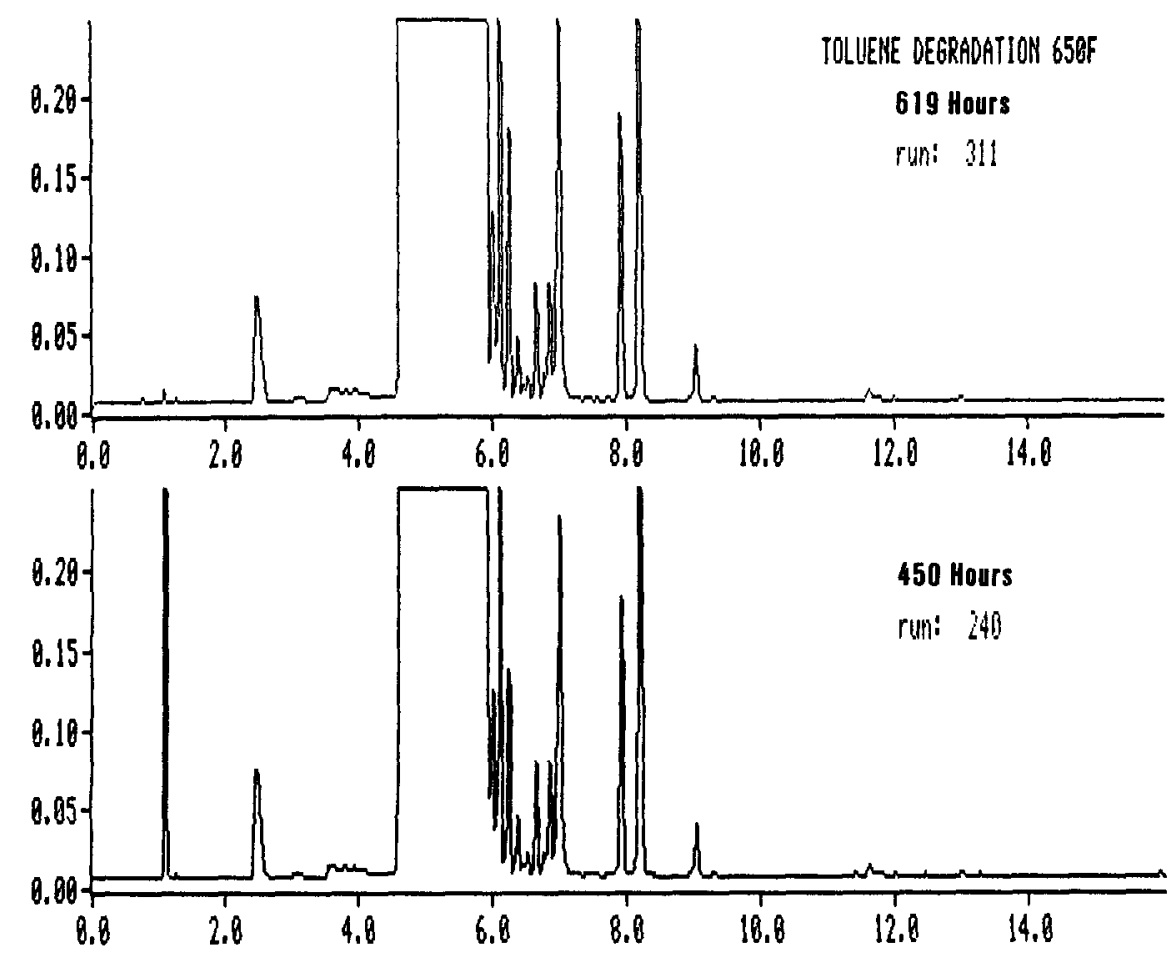

FIGURE C.15b Replotted Chromatograms for $650^{\circ} \mathrm{F}, 619$ and $450 \mathrm{~h}$, Runs 311 and 240, Time Segment $=$ 0-15 $\mathrm{min}-$ Toluene Impurities 

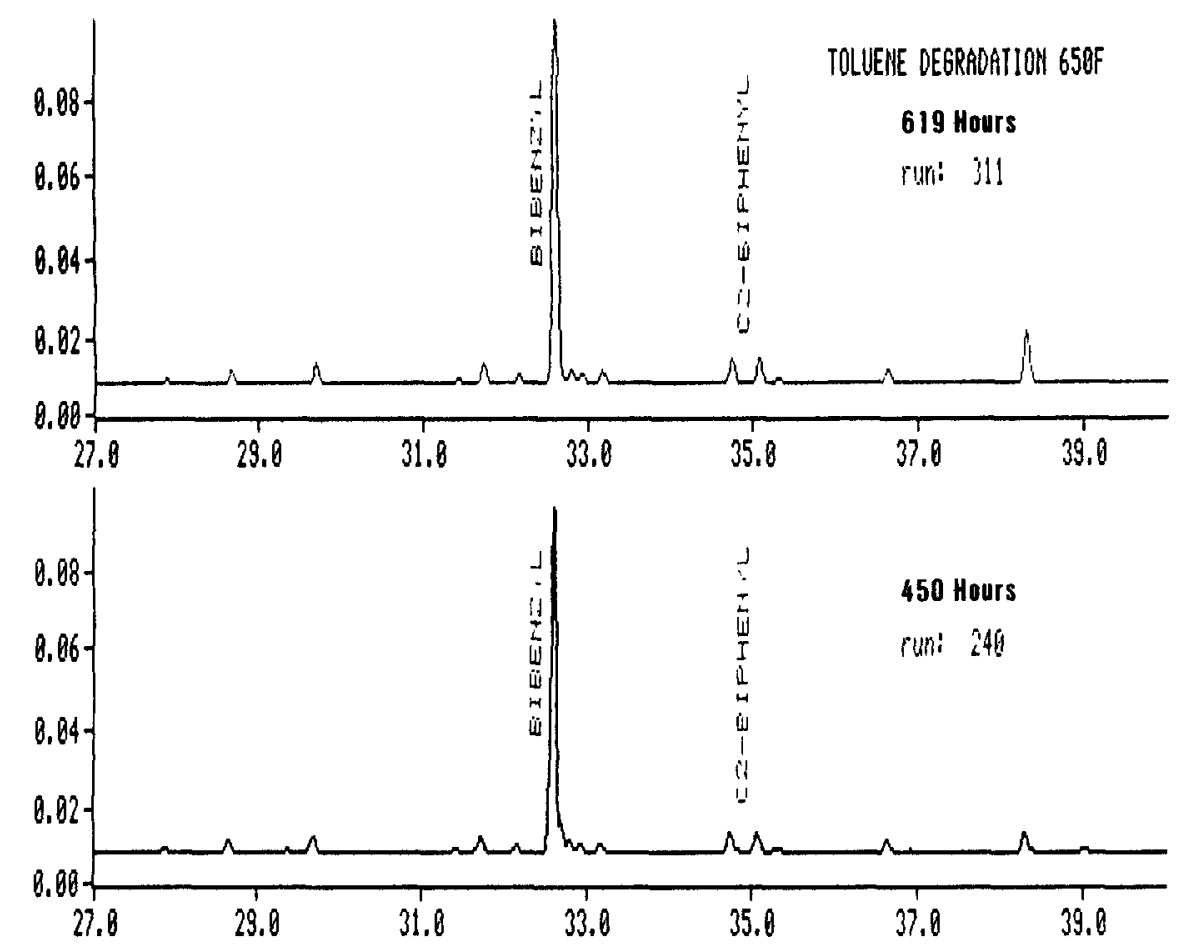

FIGURE C.15c Replotted Chromatograms for $650^{\circ} \mathrm{F}, 619$ and $450 \mathrm{~h}$, Runs 311 and 240, Time Segment $=27-40 \mathrm{~min}-$ Degradation Products

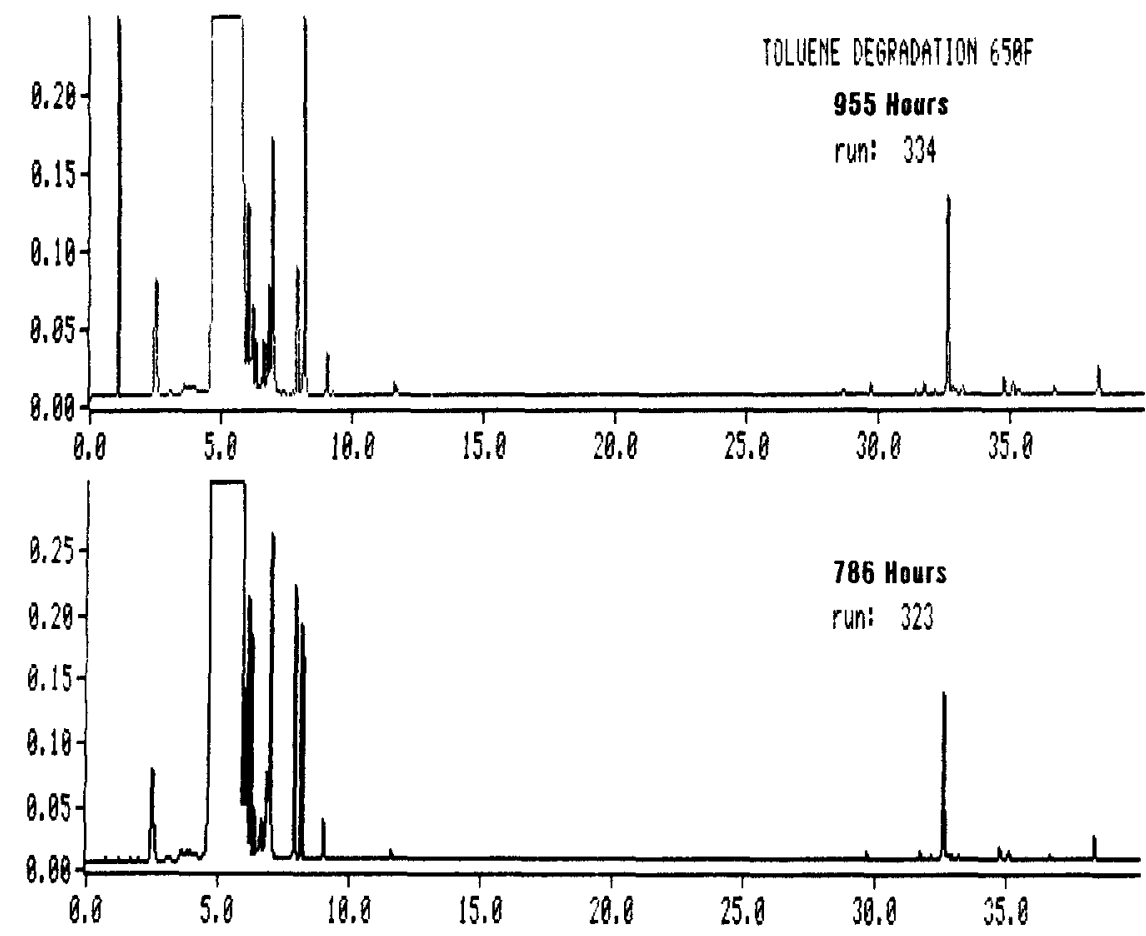

FIGURE C.16a Replotted Chromatograms for $650^{\circ} \mathrm{F}, 955$ and $786 \mathrm{~h}$, Runs 334 and 323, Time Segment $=$ 0-40 $\mathrm{min}-$ Major Components 


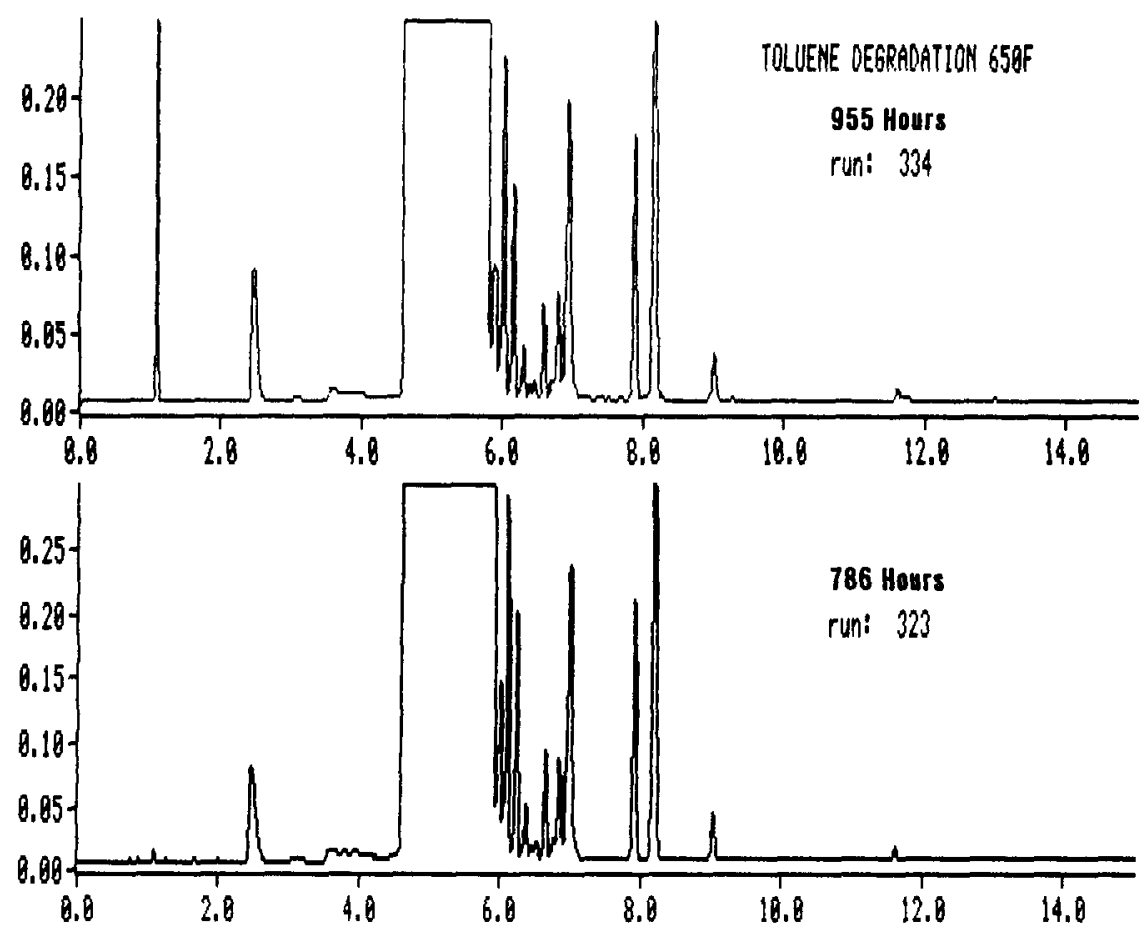

FIGURE C.16b Replotted Chromatograms for $650^{\circ} \mathrm{F}, 955$ and $786 \mathrm{~h}$, Runs 334 and 323, Time Segment $=$ 0-15 $\mathrm{min}-$ Toluene Impurities
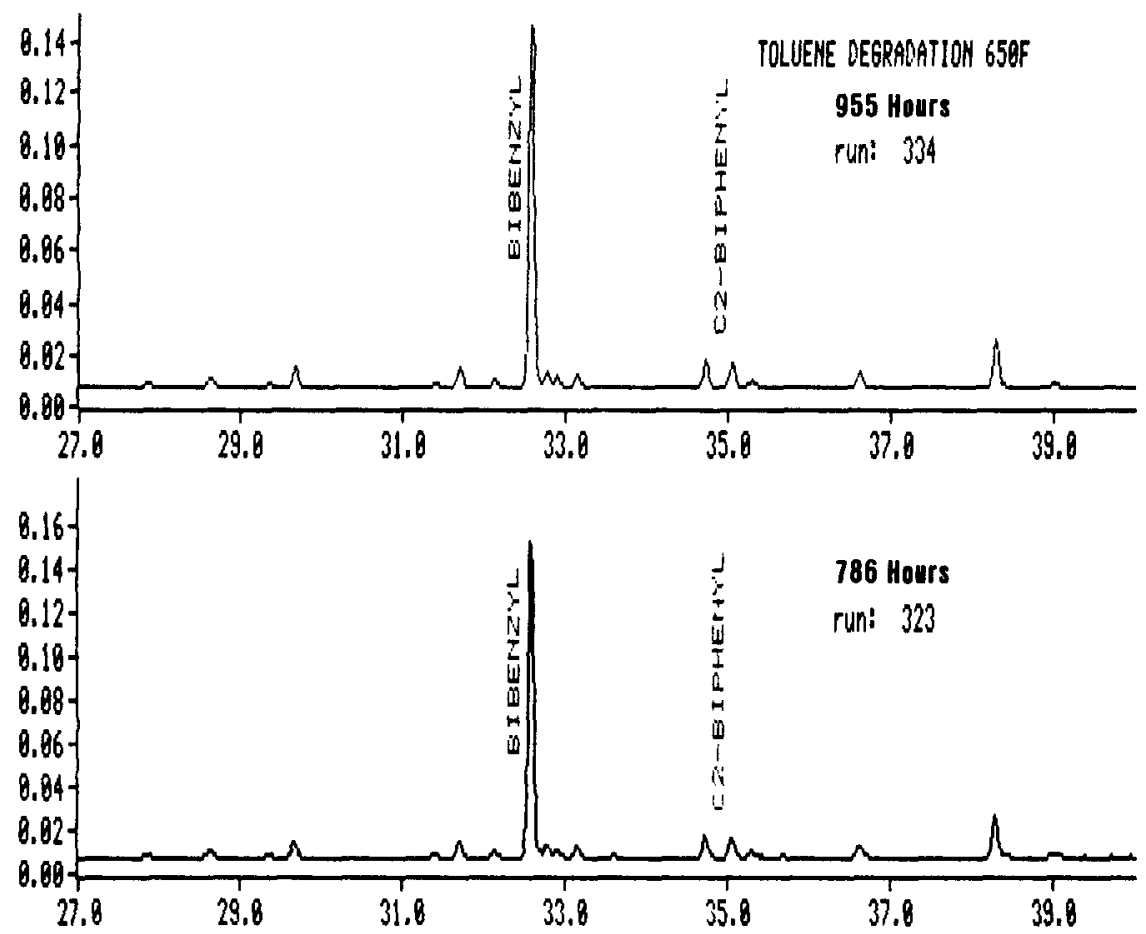

FIGURE C.16c Replotted Chromatograms for $650^{\circ} \mathrm{F}, 955$ and $786 \mathrm{~h}$, Runs 334 and 323, Time Segment $=27-40 \mathrm{~min}-$ Degradation Products 


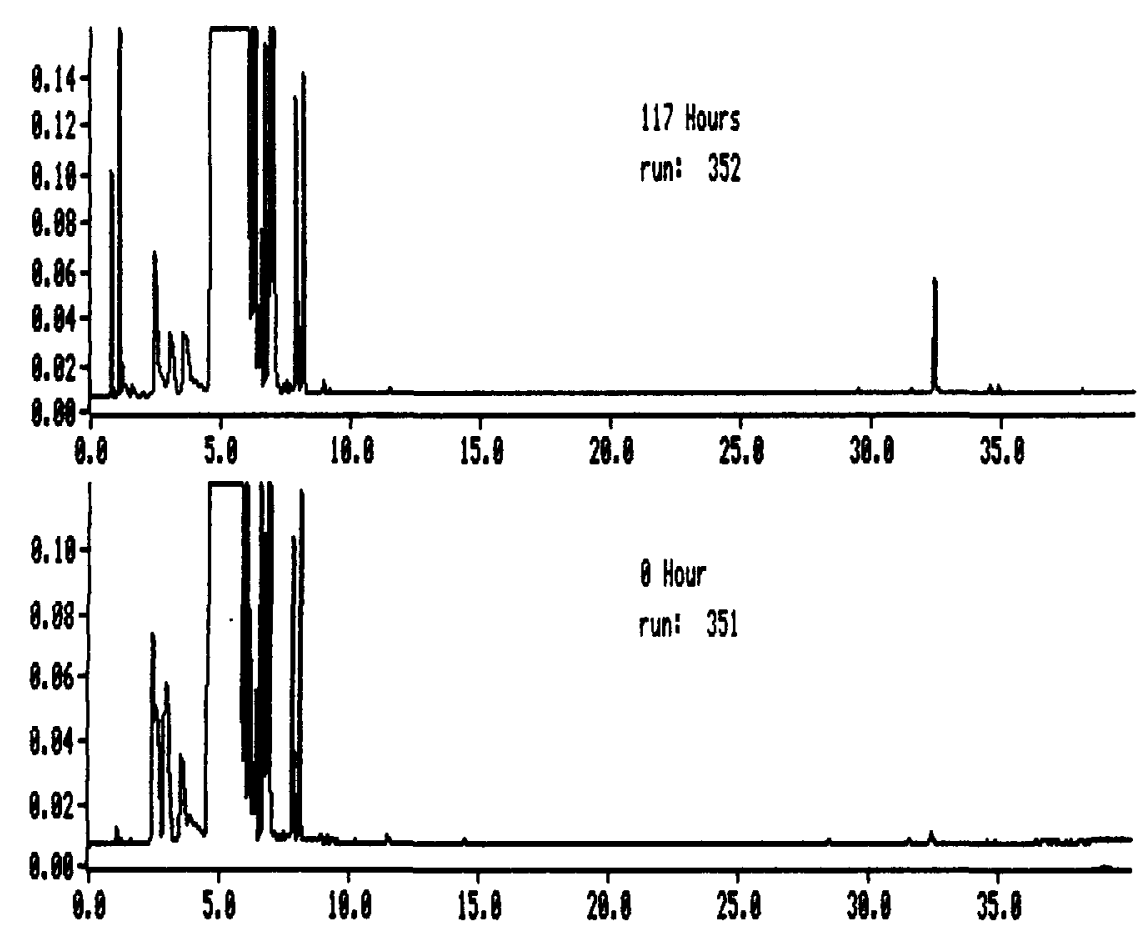

FIGURE C.17a Replotted Chromatograms for $677^{\circ} \mathrm{F}, 117$ and $0 \mathrm{~h}$, Runs 352 and 351, Time Segment = 0-40 $\mathrm{min}-$ Major Components

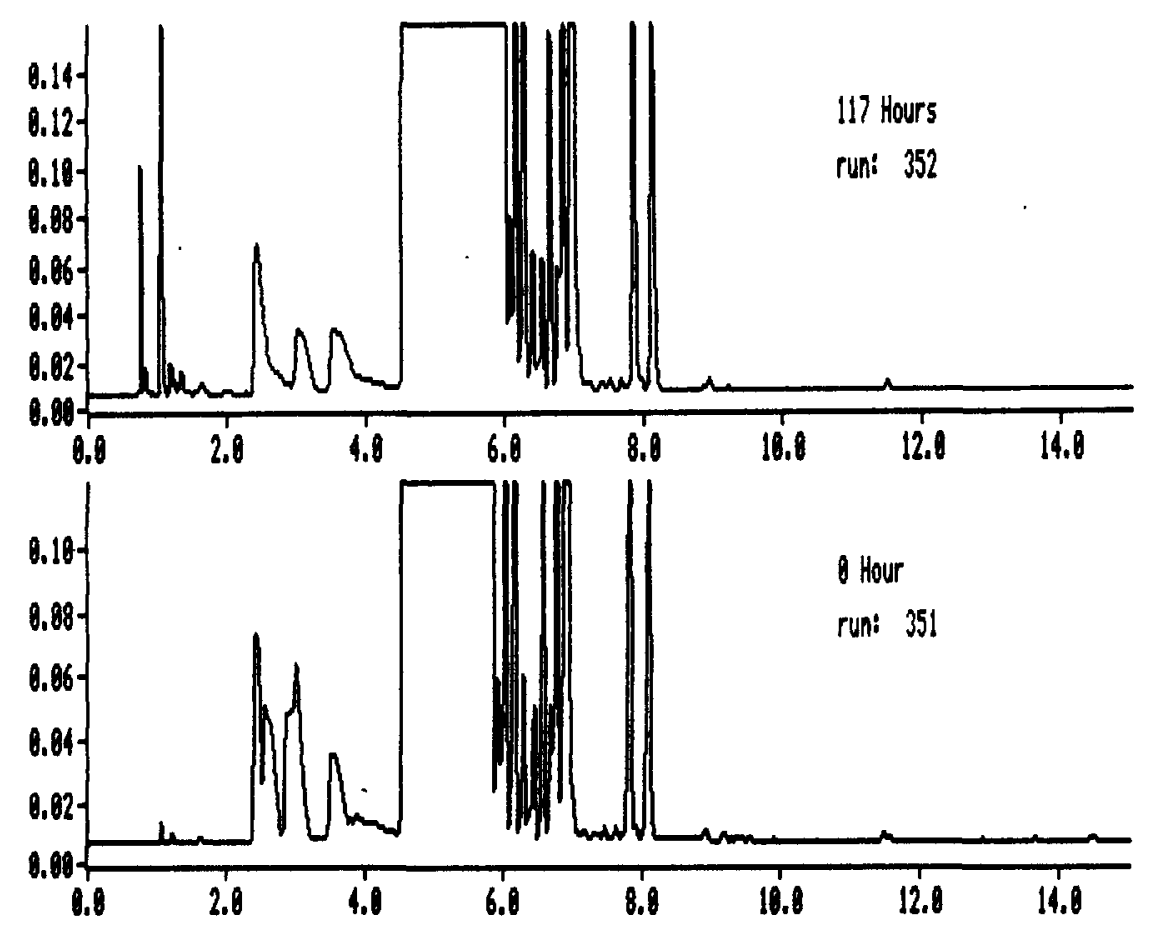

FIGURE C.17b Replotted Chromatograms for $677^{\circ} \mathrm{F}, 117$ and $0 \mathrm{~h}$, Runs 352 and 351, Time Segment = 0-15 min - Toluene Impurities 

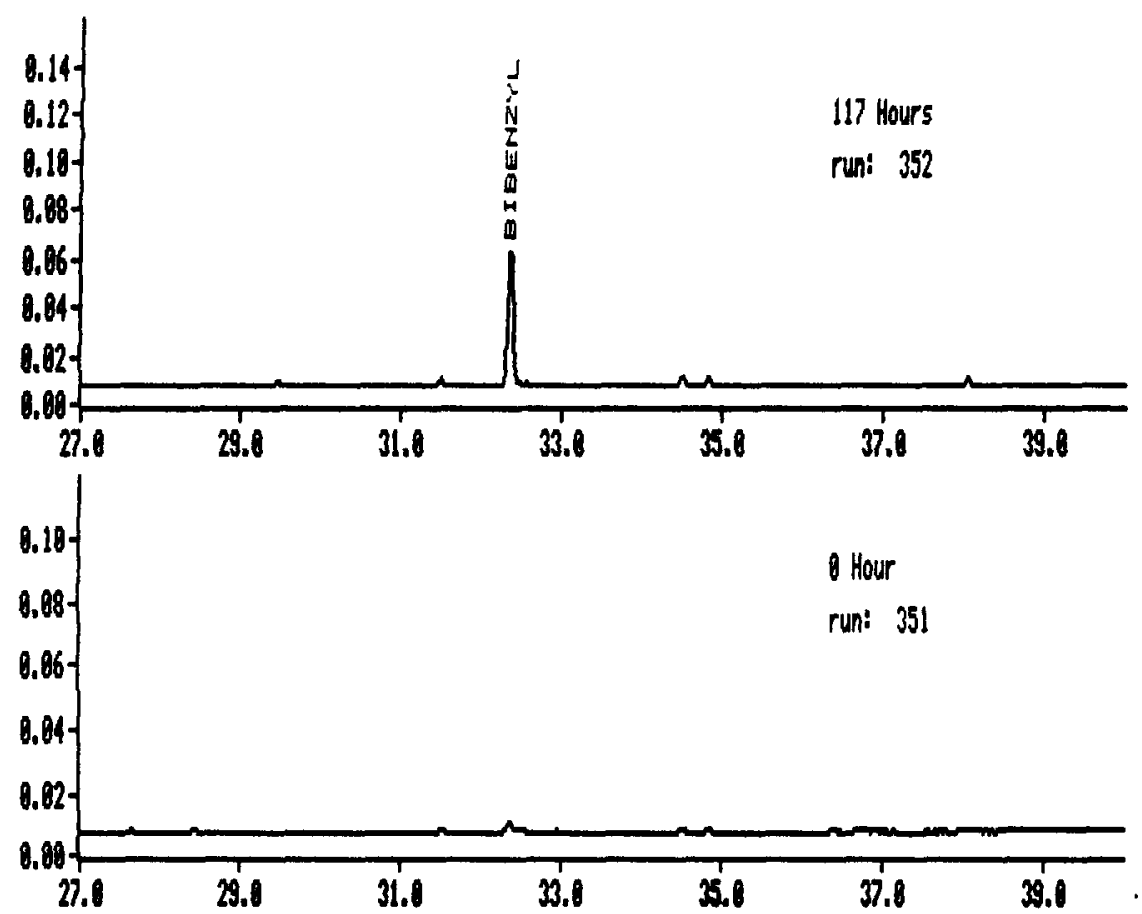

FIGURE C.17c Replotted Chromatograms for $677^{\circ} \mathrm{F}, 117$ and $0 \mathrm{~h}$, Runs 352 and 351, Time Segment $=27-40 \mathrm{~min}-$ Degradation Products
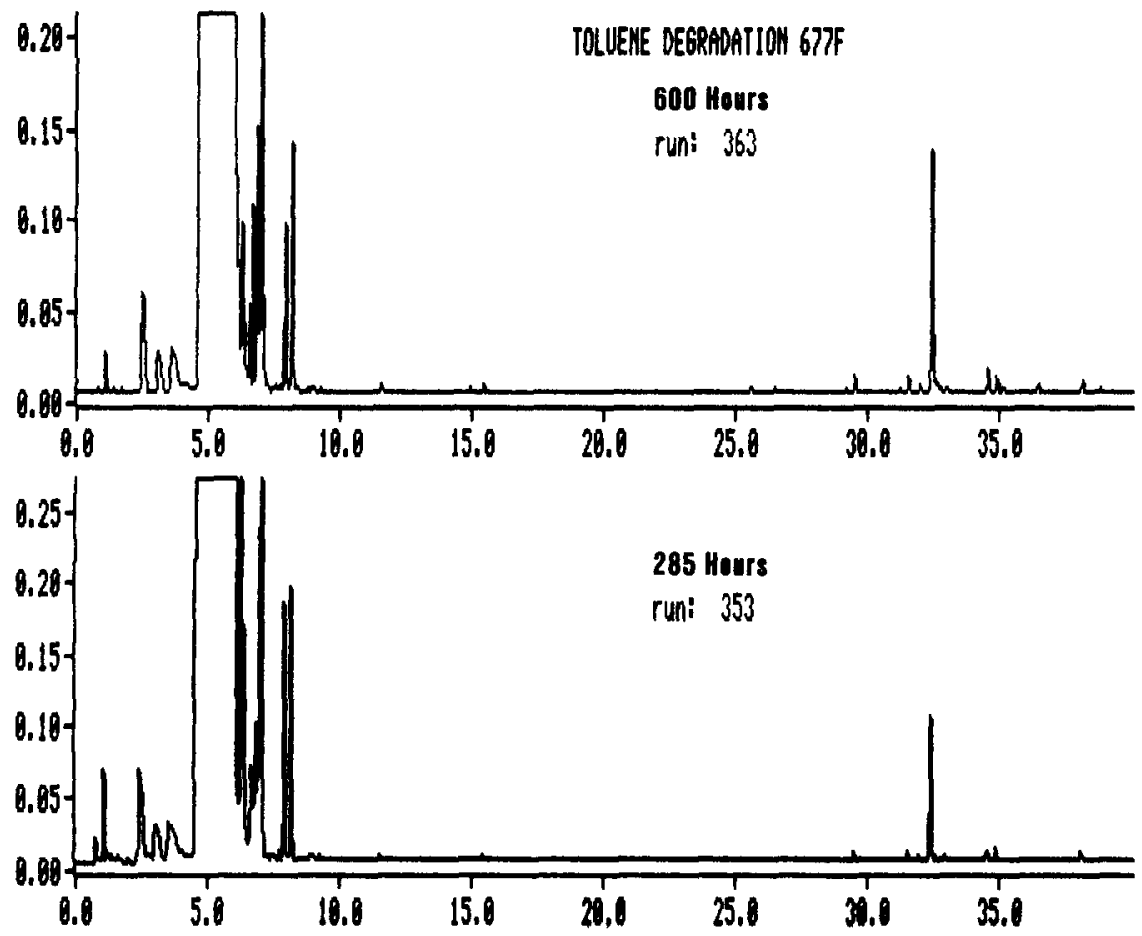

FIGURE C.18a Replotted Chromatograms for $677^{\circ} \mathrm{F}, 600$ and $285 \mathrm{~h}$, Runs 363 and 353, Time Segment $=$ 0-40 $\mathrm{min}-$ Major Components 


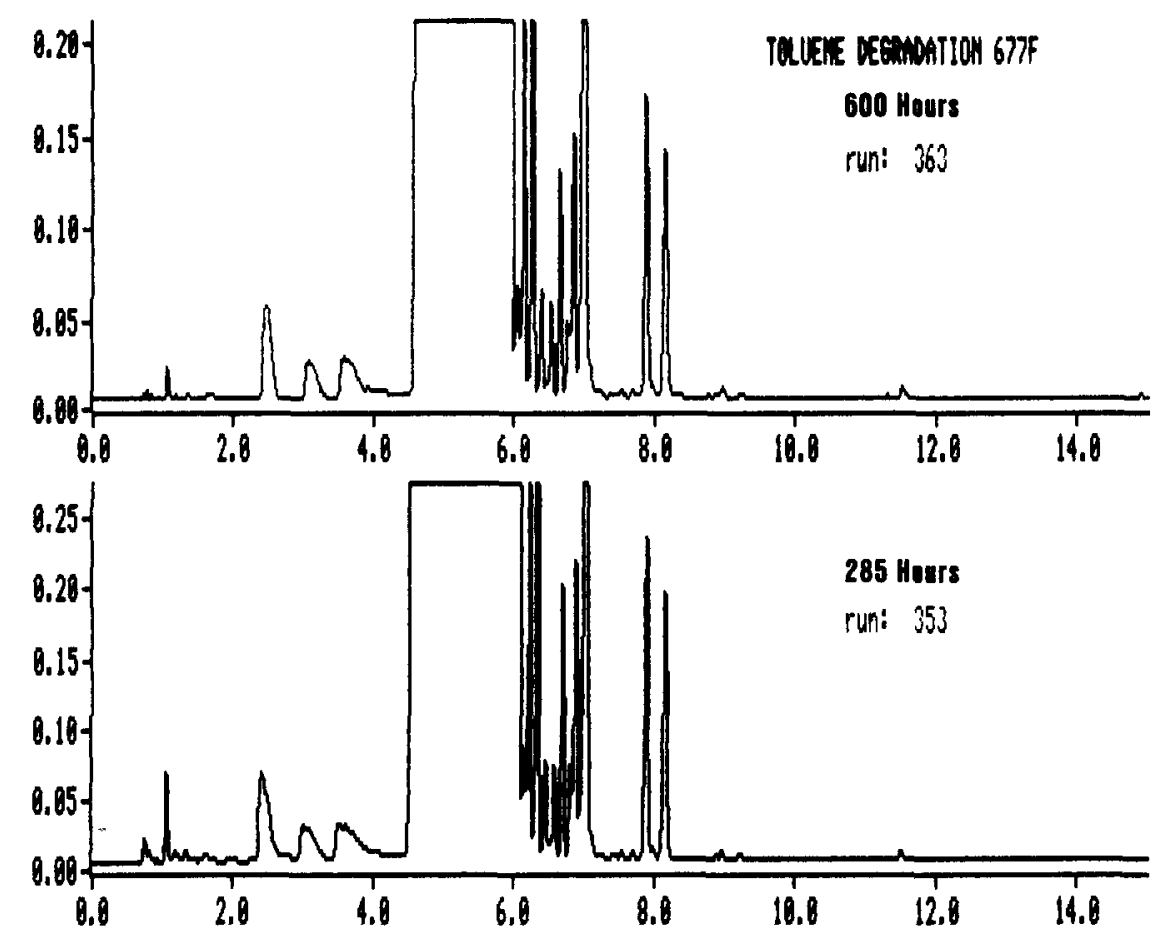

FIGURE C.18b Replotted Chromatograms for $677^{\circ} \mathrm{F}, 600$ and $285 \mathrm{~h}$, Runs 363 and 353, Time Segment $=0-15 \mathrm{~min}-$ Toluene Impurities
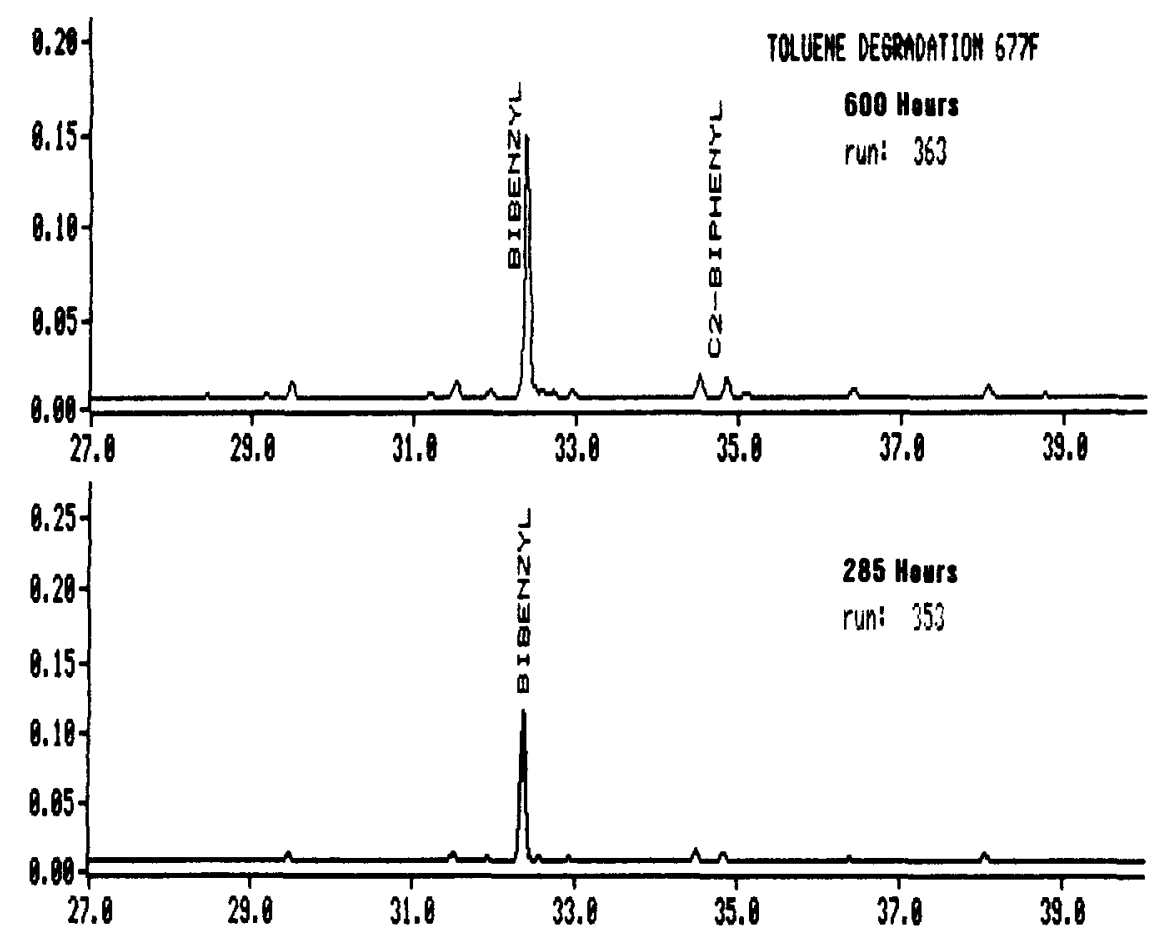

FIGURE C.18c Replotted Chromatograms for $677^{\circ} \mathrm{F}, 600$ and $285 \mathrm{~h}$, Runs 363 and 353, Time Segment = 27-40 $\mathrm{min}-$

Degradation Products 

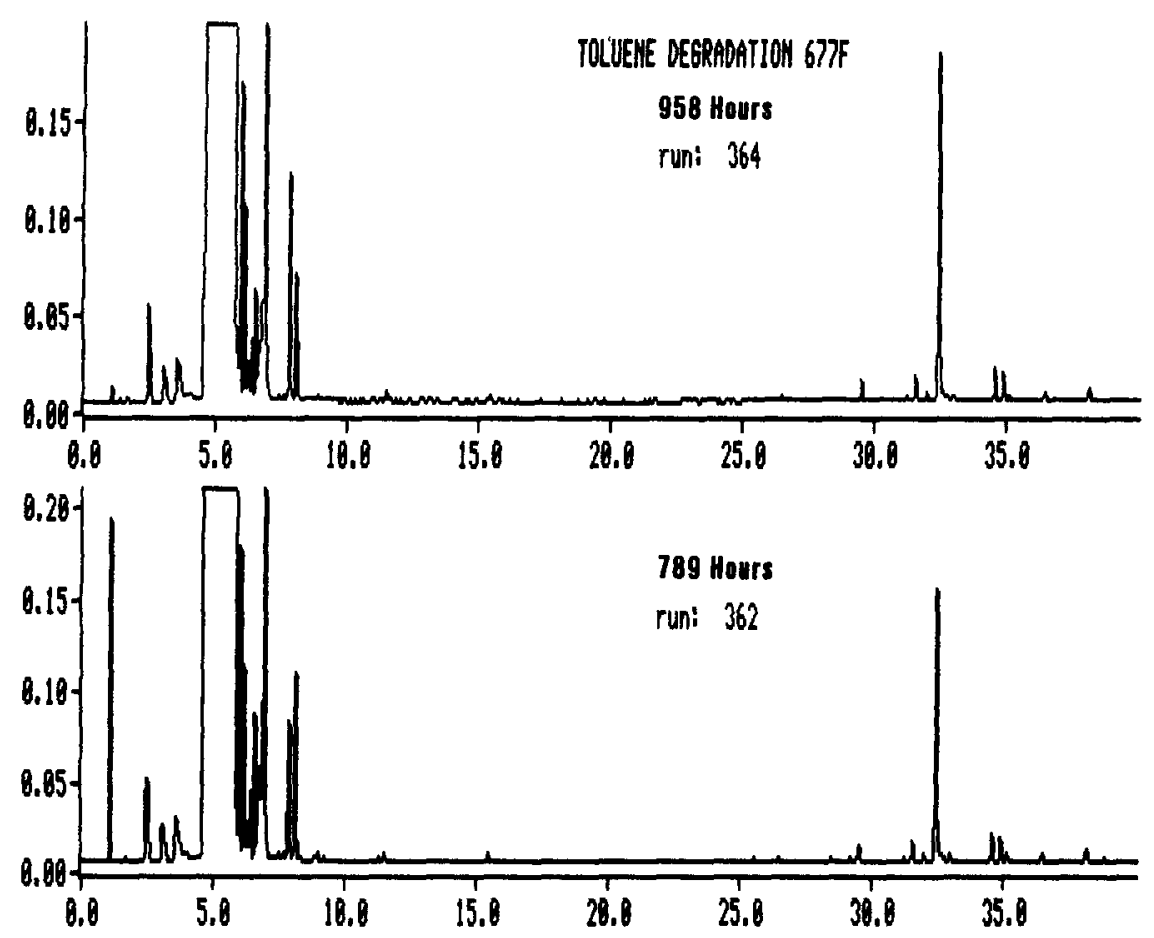

FIGURE C.19a Replotted Chromatograms for $677^{\circ} \mathrm{F}, 958$ and $789 \mathrm{~h}$, Runs 364 and 362, Time Segment $=$ 0-40 $\mathrm{min}-$ Major Components
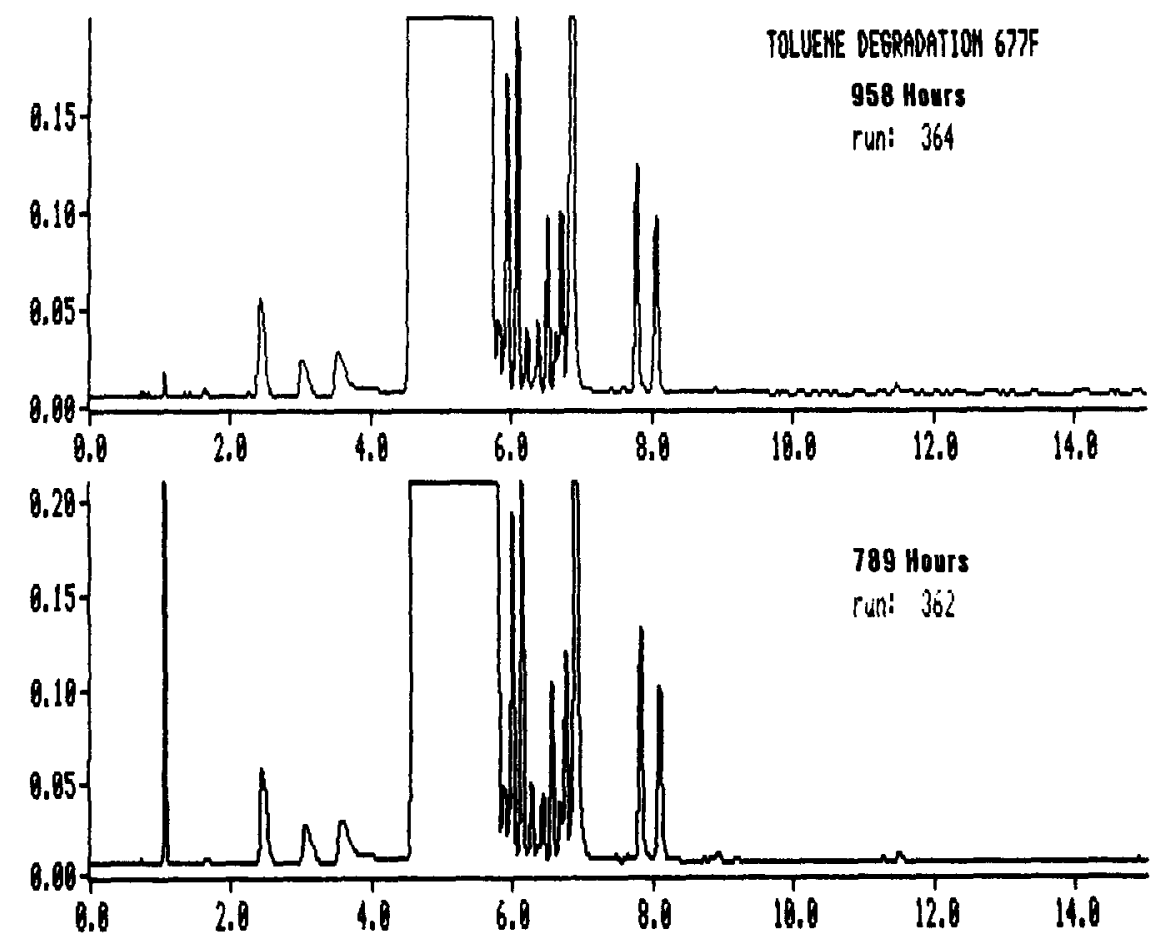

FIGURE C.19b Replotted Chromatograms for $677^{\circ} \mathrm{F}, 958$ and $789 \mathrm{~h}$, Runs 364 and 362, Time Segment = 0-15 min - Toluene Impurities 

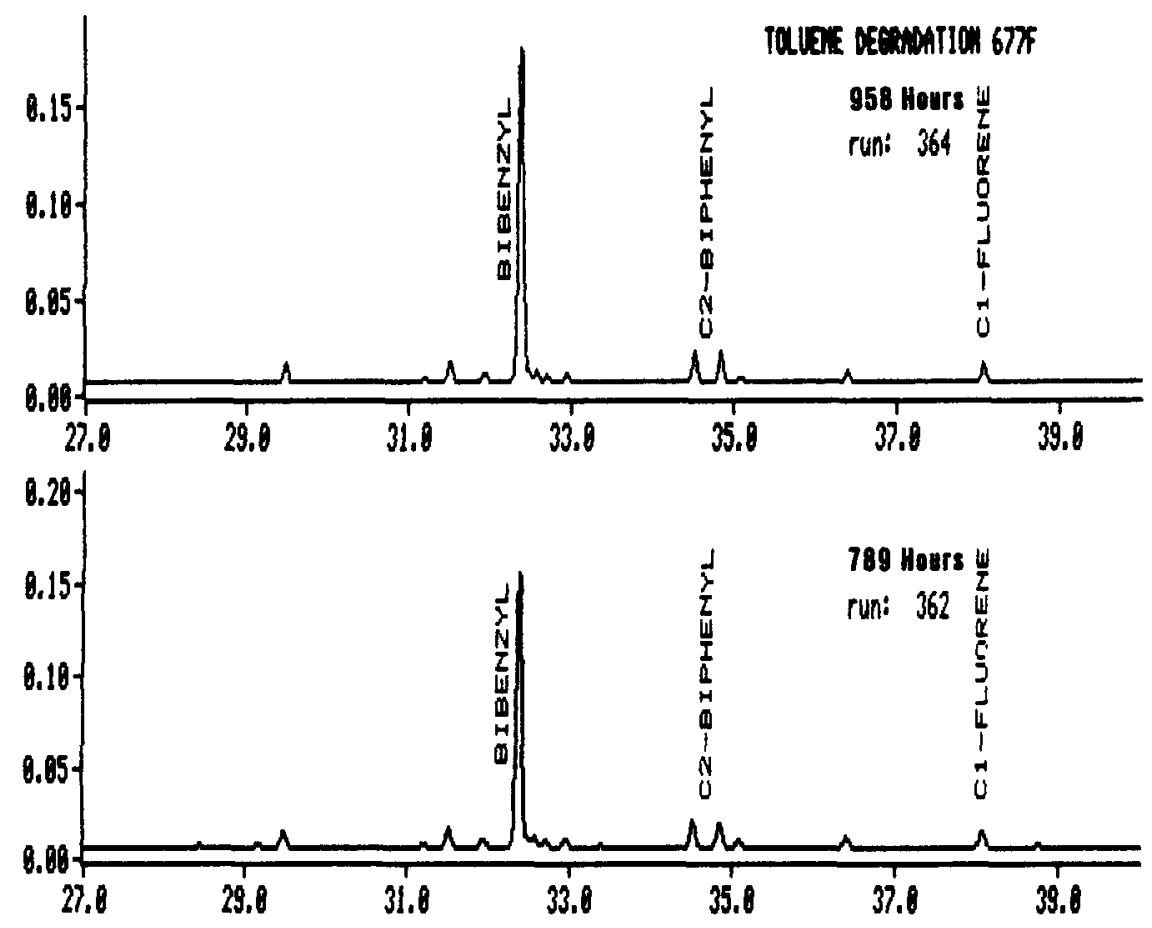

FIGURE C.19c Replotted Chromatograms for $677^{\circ} \mathrm{F}, 958$ and $789 \mathrm{~h}$, Runs 364 and 362, Time Segment $=$ 27-40 $\mathrm{min}-$ Degradation Products 
$141 / 142$

APPENDIX D:

TOLUENE DEGRADATION REPORTS 



\section{APPENDIX D: \\ TOLUENE DEGRADATION REPORTS}

TABLE D.1 Toluene Degradation Report $-635^{\circ} \mathrm{F}, 0 \mathrm{~h}$, Run 318

\begin{tabular}{|c|c|c|c|c|c|}
\hline $\begin{array}{r}\text { Peak } \\
\text { No. }\end{array}$ & Name & $\begin{array}{c}\text { Aromatic } \\
\text { Retention } \\
\quad \text { Index }\end{array}$ & $\begin{array}{l}\text { Conc. } \\
\text { (ppm) }\end{array}$ & $\begin{array}{l}\text { Ret. } \\
\text { Time } \\
\text { (min) }\end{array}$ & Area $^{a}$ \\
\hline 1 & & 135.7 & 5.8 & 1.66 & 23 \\
\hline 2 & BENZENE & 200.0 & 115.4 & 2.44 & 467 \\
\hline 3 & & 206.8 & 19.9 & 3.06 & 81 \\
\hline 4 & METHYLCYCLOHEXANE & 212.3 & 29.2 & 3.57 & 118 \\
\hline 5 & C2-CYCLOPENTANE & 215.0 & 1.0 & 3.82 & 4 \\
\hline 6 & C2-CYCLOPENTANE & 215.5 & 0.4 & 3.86 & 1 \\
\hline 7 & C2-CYCLOPENTANE & 216.4 & 2.3 & 3.95 & 9 \\
\hline 10 & C8-ALKANE & 237.0 & 33.8 & 5.83 & 137 \\
\hline 11 & C8-ALKANE & 237.5 & 48.2 & 5.87 & 195 \\
\hline 12 & C2-CYCLOHEXANE & 238.8 & 168.3 & 5.99 & 681 \\
\hline 13 & C2-CYCLOHEXANE & 240.4 & 137.4 & 6.14 & 556 \\
\hline 14 & ISOPROPYLCYCLOPENTANE & 242.0 & 28.4 & 6.28 & 115 \\
\hline 15 & & 243.0 & 5.7 & 6.37 & 23 \\
\hline 16 & ETHYLMETHYCYCLOPENTANE & 243.7 & 15.8 & 6.44 & 64 \\
\hline 17 & ETHYLMETHYCYCLOPENTANE & 245.2 & 57.4 & 6.57 & 232 \\
\hline 18 & DIMETHYLCYCLOHEXANE & 246.5 & 16.3 & 6.70 & 66 \\
\hline 19 & DIMETHYLCYCLOHEXANE & 247.4 & 72.4 & 6.78 & 293 \\
\hline 20 & ETHYLCYCLOHEXANE & 249.0 & 334.9 & 6.93 & 1355 \\
\hline 21 & ETHYLBENZENE & 259.2 & 126.0 & 7.86 & 510 \\
\hline 22 & XYLENE & 262.3 & 268.3 & 8.14 & 1085 \\
\hline 23 & & 271.7 & 23.0 & 9.00 & 81 \\
\hline
\end{tabular}

RRI REPORT

$\begin{array}{llr}\text { SAMPLE: } & \text { FD635FT3 } & \text { TOTAL CONCENTRATION }=1509.6 \\ \text { DISK FILE: } & 31802 & \text { NO. OF INTERPRETED PEAKS }=22 \\ \text { GC RUN: } & 41786 & \text { TOTAL NO. OF PEAKS }=23\end{array}$

TOLUENE DATA:

$$
\begin{array}{ll}
\mathrm{RT}=5.76 & \text { AREA }=4039750 \\
\mathrm{ARI}=236 \% & \text { CONC }=998490
\end{array}
$$

${ }^{\text {Area }}$ is in a unit that is calibrated when the standard sample is analyzed. 
TABLE D.2 Toluene Degradation Report $-635^{\circ} \mathrm{F}, 0 \mathrm{~h}$, Run 329

\begin{tabular}{|c|c|c|c|c|c|}
\hline $\begin{array}{c}\text { Peak } \\
\text { No. }\end{array}$ & Name & $\begin{array}{l}\text { Aromatic } \\
\text { Retention } \\
\text { Index }\end{array}$ & $\begin{array}{l}\text { Conc. } \\
\text { (ppm) }\end{array}$ & $\begin{array}{l}\text { Ret. } \\
\text { Time } \\
\text { (min) }\end{array}$ & Area $^{a}$ \\
\hline 1 & & 101.1 & 1.8 & 1.24 & 9 \\
\hline 2 & & 135.1 & 5.6 & 1.65 & 27 \\
\hline 3 & BENZENE & 200.0 & 112.9 & 2.44 & 543 \\
\hline 4 & & 206.7 & 19.7 & 3.05 & 95 \\
\hline 5 & METHYLCYCLOHEXANE & 212.3 & 33.6 & 3.57 & 161 \\
\hline 6 & C2-CYCLOPENTANE & 214.8 & 4.1 & 3.79 & 20 \\
\hline 9 & C8-ALKANE & 237.7 & 27.1 & 5.87 & 130 \\
\hline 10 & C8-ALKANE & 238.1 & 49.4 & 5.91 & 238 \\
\hline 11 & C2-CYCLOHEXANE & 239.4 & 164.4 & 6.03 & 791 \\
\hline 12 & ISOPROPYLCYCLOPENTANE & 240.9 & 134.5 & 6.16 & 647 \\
\hline 13 & & 242.5 & 27.6 & 6.30 & 133 \\
\hline 14 & & 243.4 & 5.4 & 6.39 & 26 \\
\hline 15 & ETHYLMETHYCYCLOPENTANE & 244.2 & 15.4 & 6.46 & 74 \\
\hline 16 & & 245.6 & 56.1 & 6.59 & 270 \\
\hline 17 & DIMETHYLCYCLOHEXANE & 246.9 & 16.0 & 6.71 & 77 \\
\hline 18 & & 247.8 & 71.0 & 6.79 & 342 \\
\hline 19 & ETHYLCYCLOHEXANE & 249.4 & 328.0 & 6.94 & 1578 \\
\hline 20 & ETHYLBENZENE & 259.6 & 122.1 & 7.87 & 587 \\
\hline 21 & XYLENE & 262.7 & 259.4 & 8.15 & 1248 \\
\hline 22 & & 272.1 & 24.3 & 9.00 & 97 \\
\hline
\end{tabular}

RRI REPORT

$\begin{array}{llr}\text { SAMPLE: } & \text { FD635FOHT3 } & \text { TOTAL CONCENTRATION }=1478.1 \\ \text { DISK FILE: } & 32902 & \text { NO. OF INTERPRETED PEAKS }=21 \\ \text { GC RUN: } & 42486 & \text { TOTAL NO. OF PEAKS }=22\end{array}$

TOLUENE DATA:

$$
\begin{array}{ll}
\text { RT }=5.80 & \text { AREA }=4805160 \\
\text { ARI }=237 \% & \text { CONC }=998522
\end{array}
$$

area is in a unit that is calibrated when the standard sample is analyzed. 
TABLE D.3 Toluene Degradation Report $-635^{\circ} \mathrm{F}, 45 \mathrm{~h}$, Run 319

\begin{tabular}{|c|c|c|c|c|c|}
\hline $\begin{array}{c}\text { Peak } \\
\text { No. }\end{array}$ & Name & $\begin{array}{l}\text { Aromatic } \\
\text { Retention } \\
\text { Index }\end{array}$ & $\begin{array}{l}\text { Conc. } \\
\text { (ppm) }\end{array}$ & $\begin{array}{l}\text { Ret. } \\
\text { Time } \\
\text { (min) }\end{array}$ & Area $^{a}$ \\
\hline 1 & & 115.4 & 2.3 & 1.43 & 15 \\
\hline 2 & & 134.7 & 6.2 & 1.67 & 41 \\
\hline 3 & BENZENE & 200.0 & 115.1 & 2.48 & 755 \\
\hline 4 & C6H14 & 206.3 & 6.2 & 3.06 & 41 \\
\hline 5 & METHYLCYCLOHEXANE & 212.0 & 1.2 & 3.57 & 8 \\
\hline 6 & C2-CYCLOPENTANE & 214.5 & 1.1 & 3.79 & 7 \\
\hline 10 & C2-CYCLOHEXANE & 240.0 & 29.2 & 6.11 & 192 \\
\hline 11 & C2-CYCLOHEXANE & 240.3 & 45.4 & 6.14 & 298 \\
\hline 12 & I SOPROPYLCYCLOPENTANE & 241.2 & 162.9 & 6.22 & 1069 \\
\hline 13 & & 242.6 & 136.0 & 6.34 & 893 \\
\hline 14 & ETHYLMETHYCYCLOPENTANE & 243.9 & 27.9 & 6.47 & 183 \\
\hline 15 & ETHYLMETHYCYCLOPENTANE & 244.7 & 5.2 & 6.54 & 34 \\
\hline 16 & & 245.5 & 15.4 & 6.61 & 101 \\
\hline 17 & DIMETHYLCYCLOHEXANE & 246.8 & 56.2 & 6.72 & 369 \\
\hline 18 & & 248.0 & 16.1 & 6.84 & 106 \\
\hline 19 & ETHYLCYCLOHEXANE & 248.9 & 71.0 & 6.92 & 466 \\
\hline 20 & ETHYLCYCLOHEXANE & 250.4 & 327.0 & 7.06 & 2146 \\
\hline 21 & ETHYLBENZENE & 260.3 & 118.9 & 7.95 & 780 \\
\hline 22 & XYLENE & 263.3 & 253.1 & 8.23 & 1661 \\
\hline 23 & & 272.5 & 23.4 & 9.06 & 134 \\
\hline 24 & BENZALDEHYDE & 300.7 & 30.9 & 11.62 & 177 \\
\hline 25 & Cl-STYRENE & 333.4 & 5.0 & 14.59 & 29 \\
\hline 26 & BIPHENYL & 473.0 & 9.1 & 27.85 & 58 \\
\hline 27 & DIPHENYLETHER & 481.0 & 22.8 & 28.64 & 145 \\
\hline 28 & BIBENZYL & 520.9 & 9.0 & 32.59 & 58 \\
\hline
\end{tabular}

RRI REPORT

SAMPLE: $\quad$ FD635F51HT3 TOTAL CONCENTRATION $=1496.9$

DISK FILE: 31902 NO. OF INTERPRETED PEAKS $=26$

GC RUN: $41786 \quad$ TOTAL NO. OF PEAKS $=28$

TOLUENE DATA:

$$
\begin{array}{ll}
\text { RT }=6.06 & \text { AREA }=6551450 \\
\text { ARI }=240 \% & \text { CONC }=998503
\end{array}
$$

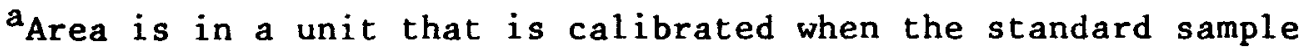
is analyzed. 
TABLE D.4 Toluene Degradation Report $-635^{\circ} \mathrm{F}, 45 \mathrm{~h}$, Run 330

\begin{tabular}{rlrrrr}
\hline & & $\begin{array}{c}\text { Aromatic } \\
\text { Retention } \\
\text { Index }\end{array}$ & $\begin{array}{r}\text { Conc. } \\
\text { (ppm) }\end{array}$ & $\begin{array}{l}\text { Ret. } \\
\text { Time } \\
\text { (min) }\end{array}$ & Area \\
\hline & & Name & & & \\
\hline 1 & & 116.0 & 1.6 & 1.42 & 9 \\
2 & & 135.5 & 5.9 & 1.66 & 35 \\
3 & BENZENE & 200.0 & 110.5 & 2.45 & 647 \\
4 & & 206.7 & 20.2 & 3.06 & 118 \\
5 & METHYLCYCLOHEXANE & 212.4 & 34.5 & 3.58 & 202 \\
6 & C2-CYCLOPENTANE & 214.7 & 8.7 & 3.79 & 51 \\
7 & C2-CYCLOPENTANE & 216.2 & 9.4 & 3.93 & 55 \\
11 & C2-CYCLOHEXANE & 239.3 & 75.1 & 6.02 & 440 \\
12 & C2-CYCLOHEXANE & 240.4 & 162.3 & 6.12 & 151 \\
13 & ISOPROPYLCYCLOPENTANE & 241.8 & 133.9 & 6.25 & 784 \\
14 & & 243.2 & 27.4 & 6.38 & 160 \\
15 & ETHYLMETHYCYCLOPENTANE & 244.1 & 5.3 & 6.46 & 31 \\
16 & ETHYLMETHYCYCLOPENTANE & 244.9 & 15.3 & 6.53 & 90 \\
17 & & 246.2 & 55.4 & 6.65 & 325 \\
18 & & 247.5 & 15.9 & 6.77 & 93 \\
19 & & 248.4 & 70.1 & 6.85 & 411 \\
20 & ETHYLCYCLOHEXANE & 250.0 & 322.1 & 6.99 & 1886 \\
21 & ETHYLBENZENE & 260.0 & 117.1 & 7.90 & 686 \\
22 & XYLENE & 263.0 & 249.1 & 8.18 & 1459 \\
23 & & 272.3 & 24.2 & 9.02 & 118 \\
24 & BENZALDEHYDE & 300.7 & 36.6 & 11.60 & 178 \\
25 & C1-STYRENE & 333.5 & 5.0 & 14.58 & 24 \\
26 & BIPHENYL & 473.0 & 9.7 & 27.83 & 53 \\
27 & DIPHENYLETHER & 481.0 & 23.9 & 28.62 & 130 \\
28 & BIBENZYL & 520.9 & 9.8 & 32.57 & 53 \\
& & & & & \\
\hline & & & & & \\
\hline
\end{tabular}

RRIREPORT

SAMPLE: $\quad$ FD635F51HT3 TOTAL CONCENTRATION $=1548.8$

DISK FILE: 33002 NO. OF INTERPRETED PEAKS $=26$

GC RUN: $42486 \quad$ TOTAL NO. OF PEAKS $=28$

TOLUENE DATA:

$$
\begin{array}{ll}
\text { RT }=5.93 & \text { AREA }=5848720 \\
\text { ARI }=238 \% & \text { CONC }=998451
\end{array}
$$

\footnotetext{
${ }^{a}$ Area is in a unit that is calibrated when the standard sample
} is analyzed. 
TABLE D.5 Toluene Degradation Report $-635^{\circ} \mathrm{F}, 45$ h, Run 340

\begin{tabular}{|c|c|c|c|c|c|}
\hline $\begin{array}{c}\text { Peak } \\
\text { No. }\end{array}$ & Name & $\begin{array}{l}\text { Aromatic } \\
\text { Retention } \\
\text { Index }\end{array}$ & $\begin{array}{l}\text { Conc. } \\
\text { (ppm) }\end{array}$ & $\begin{array}{l}\text { Ret. } \\
\text { Time } \\
\text { (min) }\end{array}$ & Area $^{a}$ \\
\hline 1 & & 114.8 & 1.8 & 1.42 & 10 \\
\hline 2 & & 134.5 & 6.1 & 1.66 & 35 \\
\hline 3 & BENZENE & 200.0 & 110.5 & 2.47 & 636 \\
\hline 4 & & 206.8 & 20.7 & 3.08 & 119 \\
\hline 8 & C2-CYCLOHEXANE & 239.1 & 30.6 & 6.01 & 176 \\
\hline 9 & C2-CYCLOHEXANE & 239.5 & 45.9 & 6.04 & 264 \\
\hline 10 & ISOPROPYLCYCLOPENTANE & 240.5 & 164.0 & 6.13 & 943 \\
\hline 11 & I SOPROPYLCYCLOPENTANE & 241.9 & 135.6 & 6.26 & 780 \\
\hline 12 & & 243.3 & 27.8 & 6.39 & 160 \\
\hline 13 & ETHYLMETHYCYCLOPENTANE & 244.2 & 5.4 & 6.46 & 31 \\
\hline 14 & ETHYLMETHYCYCLOPENTANE & 245.0 & 15.5 & 6.53 & 89 \\
\hline 15 & & 246.3 & 56.5 & 6.65 & 325 \\
\hline 16 & & 247.6 & 16.2 & 6.77 & 93 \\
\hline 17 & & 248.4 & 71.3 & 6.85 & 411 \\
\hline 18 & ETHYLCYCLOHEXANE & 250.0 & 327.5 & 6.99 & 1884 \\
\hline 19 & ETHYLBENZENE & 260.0 & 120.3 & 7.89 & 692 \\
\hline 20 & XYLENE & 263.0 & 257.4 & 8.16 & 1481 \\
\hline 24 & BIPHENYL & 473.0 & 9.7 & 27.74 & 54 \\
\hline 25 & DIPHENYLETHER & 481.0 & 23.8 & 28.53 & 134 \\
\hline 26 & BIBENZYL & 520.9 & 10.1 & 32.46 & 56 \\
\hline
\end{tabular}

RRI REPORT

$\begin{array}{llr}\text { SAMPLE: } & \text { FD635F51HT3 } & \text { TOTAL CONCENTRATION }=1515.9 \\ \text { DISK FILE: } & 34002 & \text { NO. OF INTERPRETED PEAKS }=24 \\ \text { GC RUN: } & 5686 & \text { TOTAL NO. OF PEAKS }=26\end{array}$

TOLUENE DATA:

$$
\begin{array}{ll}
\mathrm{RT}=5.95 & \text { AREA }=5743420 \\
\mathrm{ARI}=239 \% & \text { CONC }=998484
\end{array}
$$

${ }^{a}$ Area is in a unit that is calibrated when the standard sample is analyzed. 
TABLE D.6 Toluene Degradation Report $-635^{\circ} \mathrm{F}, 45 \mathrm{~h}$, Run 341

\begin{tabular}{rlrrrr}
\hline Peak & Name & $\begin{array}{c}\text { Aromatic } \\
\text { Retention } \\
\text { Index }\end{array}$ & $\begin{array}{r}\text { Conc. } \\
\text { (ppm) }\end{array}$ & $\begin{array}{l}\text { Ret. } \\
\text { Time } \\
\text { (min) }\end{array}$ & Area $^{\text {a }}$ \\
\hline & & 115.7 & 1.8 & 1.40 & 10 \\
1 & & 135.0 & 6.0 & 1.63 & 33 \\
2 & & 200.0 & 113.5 & 2.42 & 617 \\
3 & BENZENE & 206.7 & 21.0 & 3.02 & 114 \\
4 & METHYLCYCLOHEXANE & 212.5 & 36.9 & 3.54 & 201 \\
5 & C2-CYCLOPENTANE & 216.2 & 11.8 & 3.87 & 64 \\
6 & 240.1 & 131.3 & 6.03 & 715 \\
10 & C2-CYCLOHEXANE & 241.5 & 129.7 & 6.16 & 706 \\
11 & ISOPROPYLCYCLOPENTANE & 243.0 & 26.0 & 6.29 & 142 \\
12 & & 244.6 & 19.1 & 6.44 & 104 \\
13 & ETHYLMETHYCYCLOPENTANE & 246.0 & 56.3 & 6.56 & 307 \\
14 & & 248.1 & 87.8 & 6.75 & 478 \\
15 & & 249.7 & 328.6 & 6.90 & 1788 \\
16 & ETHYLCYCLOHEXANE & 259.8 & 119.0 & 7.80 & 648 \\
17 & ETHYLENZENE & 262.8 & 252.9 & 8.08 & 1376 \\
18 & XYLENE & 272.1 & 20.7 & 8.91 & 112 \\
19 & & 300.5 & 34.9 & 11.47 & 168 \\
20 & BENZALDEHYDE & 333.3 & 6.1 & 14.43 & 29 \\
21 & C1-STYRENE & 473.0 & 9.6 & 27.64 & 51 \\
22 & BIPHENYL & 481.1 & 23.3 & 28.43 & 123 \\
23 & DIPHENYLETHER & 520.9 & 10.2 & 32.36 & 54 \\
24 & BIBENZYL & & & & \\
\hline
\end{tabular}

RRI REPORT

$\begin{array}{ll}\text { SAMPLE: } & \text { FD635F51HT3 } \\ \text { DISK FILE: } & 34102\end{array}$

TOTAL CONCENTRATION $=1446.7$

GC RUN: $\quad 5686$

NO. OF INTERPRETED PEAKS $=22$

TOTAL NO. OF PEAKS $=24$

TOLUENE DATA:

$$
\begin{array}{ll}
\mathrm{RT}=5.83 & \text { AREA }=5434100 \\
\mathrm{ARI}=238 \% & \mathrm{CONC}=998553
\end{array}
$$

${ }^{a}$ Area is in a unit that is calibrated when the standard sample is analyzed. 
TABLE D.7 Toluene Degradation Report $-635^{\circ} \mathrm{F}, 168 \mathrm{~h}$, Run 320

\begin{tabular}{|c|c|c|c|c|c|}
\hline $\begin{array}{c}\text { Peak } \\
\text { No. }\end{array}$ & Name & $\begin{array}{l}\text { Aromatic } \\
\text { Retention } \\
\text { Index }\end{array}$ & $\begin{array}{l}\text { Conc. } \\
\text { (ppm) }\end{array}$ & $\begin{array}{l}\text { Ret. } \\
\text { Time } \\
\text { (min) }\end{array}$ & Area $^{a}$ \\
\hline 1 & & 135.9 & 3.2 & 1.66 & 17 \\
\hline 2 & BENZENE & 200.0 & 79.3 & 2.44 & 415 \\
\hline 3 & & 206.7 & 19.5 & 3.05 & 102 \\
\hline 4 & METHYLCYCLOHEXANE & 212.6 & 34.4 & 3.59 & 180 \\
\hline 5 & C2-CYCLOPENTANE & 214.9 & 8.6 & 3.79 & 45 \\
\hline 6 & C2-CYCLOPENTANE & 216.5 & 9.5 & 3.95 & 50 \\
\hline 10 & C2-CYCLOHEXANE & 239.2 & 78.8 & 6.00 & 412 \\
\hline 11 & C2-CYCLOHEXANE & 240.3 & 166.2 & 6.10 & 868 \\
\hline 12 & ISOPROPYLCYCLOPENTANE & 241.7 & 137.0 & 6.24 & 716 \\
\hline 13 & & 243.2 & 28.0 & 6.37 & 146 \\
\hline 14 & ETHYLMETHYCYCLOPENTANE & 244.1 & 5.3 & 6.45 & 28 \\
\hline 15 & ETHYLMETHYCYCLOPENTANE & 244.9 & 15.7 & 6.52 & 82 \\
\hline 16 & & 246.2 & 56.6 & 6.65 & 296 \\
\hline 17 & & 247.6 & 16.2 & 6.77 & 85 \\
\hline 18 & & 248.4 & 71.9 & 6.85 & 376 \\
\hline 19 & ETHYLCYCLOHEXANE & 250.0 & 330.6 & 6.99 & 1727 \\
\hline 20 & ETHYLBENZENE & 260.1 & 120.9 & 7.91 & 632 \\
\hline 21 & XYLENE & 263.1 & 258.1 & 8.18 & 1349 \\
\hline 22 & & 272.4 & 24.2 & 9.03 & 110 \\
\hline 23 & BENZALDEHYDE & 300.8 & 23.6 & 11.61 & 107 \\
\hline 24 & DIPHENYLETHER & 481.1 & 4.1 & 28.65 & 21 \\
\hline 25 & BIBENZYL & 520.9 & 19.7 & 32.58 & 101 \\
\hline
\end{tabular}

RRI REPORT

$\begin{array}{llr}\text { SAMPLE: } & \text { FD635F176HT3 } & \text { TOTAL CONCENTRATION }=1511.4 \\ \text { DISK FILE: } & 32002 & \text { NO. OF INTERPRETED PEAKS }=23 \\ \text { GC RUN: } & 41786 & \text { TOTAL NO. OF PEAKS }=25\end{array}$

TOLUENE DATA:

$$
\begin{array}{ll}
\mathrm{RT}=5.91 & \text { AREA }=5217830 \\
\mathrm{ARI}=238 \% & \text { CONC }=998489
\end{array}
$$

${ }^{\text {Area }}$ is in a unit that is calibrated when the standard sample is analyzed. 
TABLE D.8 Toluene Degradation Report $-635^{\circ} \mathrm{F}, 168 \mathrm{~h}$, Run 331

\begin{tabular}{rlrrrr}
\hline $\begin{array}{r}\text { Peak } \\
\text { No. }\end{array}$ & \multicolumn{1}{c}{ Name } & $\begin{array}{c}\text { Aromatic } \\
\text { Retention } \\
\text { Index }\end{array}$ & $\begin{array}{r}\text { Conc. } \\
\text { (ppm) }\end{array}$ & $\begin{array}{l}\text { Ret. } \\
\text { Time } \\
\text { (min) }\end{array}$ & Area $^{\text {a }}$ \\
\hline & BENZENE & 200.0 & 67.1 & 2.43 & 306 \\
1 & METHYLCYCLOHEXANE & 212.6 & 32.0 & 3.58 & 146 \\
2 & C2-CYCLOPENTANE & 215.1 & 4.0 & 3.80 & 19 \\
3 & C2-CYCLOPENTANE & 216.5 & 1.3 & 3.93 & 6 \\
4 & 237.6 & 33.1 & 5.85 & 151 \\
9 & C8-ALKANE & 238.1 & 47.0 & 5.89 & 215 \\
10 & C8-ALKANE & 239.3 & 164.3 & 6.01 & 751 \\
11 & C2-CYCLOHEXANE & 240.9 & 134.4 & 6.15 & 614 \\
12 & ISOPROPYLCYCLOPENTANE & 242.5 & 27.5 & 6.29 & 125 \\
13 & & 243.5 & 5.5 & 6.38 & 25 \\
14 & ETHYLMETHYCYCLOPENTANE & 244.2 & 15.4 & 6.45 & 70 \\
15 & ETHYLMETHYCYCLOPENTANE & 245.6 & 55.6 & 6.58 & 254 \\
16 & & 247.0 & 16.2 & 6.70 & 74 \\
17 & DIMETHYLCYCLOHEXANE & 247.9 & 70.2 & 6.78 & 321 \\
18 & & 249.5 & 323.4 & 6.93 & 1478 \\
19 & ETHYLCYCLOHEXANE & 259.7 & 117.0 & 7.86 & 534 \\
20 & ETHYLBENZENE & 262.8 & 251.5 & 8.14 & 1149 \\
21 & XYLENE & 272.2 & 20.0 & 8.99 & 92 \\
22 & & 300.7 & 21.1 & 11.59 & 80 \\
23 & BENZALDEHYDE & 520.9 & 13.0 & 32.57 & 55 \\
24 & BIBENZYL & & & & \\
\hline
\end{tabular}

RRI REPORT

$\begin{array}{llr}\text { SAMPLE : } & \text { FD635F176HT3 } & \text { TOTAL CONCENTRATION }=1419.5 \\ \text { DISK FILE: } & 33102 & \text { NO. OF INTERPRETED PEAKS }=21 \\ \text { GC RUN }: & 42486 & \text { TOTAL NO. OF PEAKS }=24\end{array}$

TOLUENE DATA:

$$
\begin{array}{ll}
\mathrm{RT}=5.78 & \text { AREA }=4561510 \\
\mathrm{ARI}=237 \% & \text { CONC }=998581
\end{array}
$$

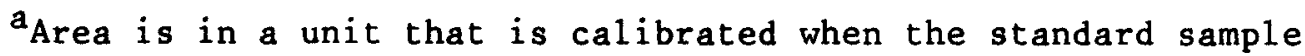
is analyzed. 
TABLE D.9 Toluene Degradation Report $-635^{\circ} \mathrm{F}, 338 \mathrm{~h}$, Run 321

\begin{tabular}{|c|c|c|c|c|c|}
\hline $\begin{array}{r}\text { Peak } \\
\text { No. }\end{array}$ & Name & $\begin{array}{l}\text { Aromatic } \\
\text { Retention } \\
\text { Index }\end{array}$ & $\begin{array}{l}\text { Conc. } \\
(\mathrm{ppm})\end{array}$ & $\begin{array}{l}\text { Ret. } \\
\text { Time } \\
\text { (min) }\end{array}$ & Area $^{a}$ \\
\hline 1 & & 135.5 & 7.2 & 1.66 & 34 \\
\hline 2 & BENZENE & 200.0 & 62.3 & 2.45 & 292 \\
\hline 3 & & 206.9 & 17.1 & 3.08 & 80 \\
\hline 4 & METHYLCYCLOHEXANE & 212.4 & 27.5 & 3.58 & 129 \\
\hline 5 & C2-CYCLOPENTANE & 214.8 & 2.6 & 3.80 & 12 \\
\hline 6 & C2-CYCLOPENTANE & 216.3 & .5 & 3.93 & 2 \\
\hline 12 & C8-ALKANE & 238.1 & 32.7 & 5.91 & 154 \\
\hline 13 & C2-CYCLOHEXANE & 238.5 & 47.4 & 5.95 & 223 \\
\hline 14 & C2-CYCLOHEXANE & 239.7 & 167.2 & 6.06 & 786 \\
\hline 15 & ISOPROPYLCYCLOPENTANE & 241.2 & 137.9 & 6.19 & 648 \\
\hline 16 & & 242.7 & 28.3 & 6.33 & 133 \\
\hline 17 & ETHYLMETHYCYCLOPENTANE & 243.7 & 5.6 & 6.42 & 26 \\
\hline 18 & ETHYLMETHYCYCLOPENTANE & 244.4 & 16.0 & 6.49 & 75 \\
\hline 19 & & 245.8 & 57.4 & 6.62 & 269 \\
\hline 20 & DIMETHYLCYCLOHEXANE & 247.1 & 16.7 & 6.74 & 78 \\
\hline 21 & & 248.0 & 72.8 & 6.82 & 342 \\
\hline 22 & ETHYLCYCLOHEXANE & 249.6 & 335.0 & 6.96 & 1574 \\
\hline 23 & ETHYLBENZENE & 259.8 & 123.7 & 7.89 & 581 \\
\hline 24 & XYLENE & 262.9 & 267.4 & 8.17 & 1256 \\
\hline 25 & & 272.2 & 25.7 & 9.02 & 105 \\
\hline 26 & BENZALDEHYDE & 300.7 & 12.0 & 11.61 & 49 \\
\hline 27 & BIBENZYL & 520.9 & 24.7 & 32.59 & 115 \\
\hline 28 & C1-FLUORENE & 578.8 & 7.4 & 38.32 & 34 \\
\hline
\end{tabular}

RRI REPORT

SAMPLE: FD635F344T3

DISK FILE: 32102

GC RUN: $\quad 41786$
TOTAL CONCENTRATION $=1594.9$

NO. OF INTERPRETED PEAKS $=24$ TOTAL NO. OF PEAKS $=28$

TOLUENE DATA:

$$
\begin{array}{ll}
\mathrm{RT}=5.84 & \text { AREA }=4690700 \\
\mathrm{ARI}=2387 & \text { CONC }=998505
\end{array}
$$

${ }^{\text {area }}$ is in a unit that is calibrated when the standard sample is analyzed. 
TABLE D.10 Toluene Degradation Report $-635^{\circ} \mathrm{F}, 338 \mathrm{~h}$, Run 332

\begin{tabular}{|c|c|c|c|c|c|}
\hline $\begin{array}{c}\text { Peak } \\
\text { No. }\end{array}$ & Name & $\begin{array}{l}\text { Aromatic } \\
\text { Retention } \\
\quad \text { Index }\end{array}$ & $\begin{array}{l}\text { Conc. } \\
\text { (ppm) }\end{array}$ & $\begin{array}{l}\text { Ret. } \\
\text { Time } \\
\text { (min) }\end{array}$ & Area $^{a}$ \\
\hline 1 & & 135.6 & 7.2 & 1.66 & 32 \\
\hline 2 & BENZENE & 200.0 & 64.4 & 2.44 & 287 \\
\hline 3 & & 206.7 & 17.1 & 3.05 & 76 \\
\hline 4 & METHYLCYCLOHEXANE & 212.3 & 33.3 & 3.56 & 149 \\
\hline 5 & C2-CYCLOPENTANE & 215.0 & 7.2 & 3.80 & 32 \\
\hline 11 & C8-ALKANE & 237.3 & 32.4 & 5.83 & 144 \\
\hline 12 & C8-ALKANE & 237.8 & 45.5 & 5.87 & 203 \\
\hline 13 & C2-CYCLOHEXANE & 239.1 & 164.8 & 5.99 & 734 \\
\hline 14 & ISOPROPYLCYCLOPENTANE & 240.6 & 135.5 & 6.14 & 604 \\
\hline 15 & ISOPROPYLCYCLOPENTANE & 242.2 & 27.7 & 6.28 & 123 \\
\hline 16 & & 243.2 & 5.4 & 6.37 & 24 \\
\hline 17 & ETHYLMETHYCYCLOPENTANE & 244.0 & 15.6 & 6.44 & 70 \\
\hline 18 & ETHYLMETHYCYCLOPENTANE & 245.4 & 56.5 & 6.57 & 252 \\
\hline 19 & DIMETHYLCYCLOHEXANE & 246.8 & 16.3 & 6.69 & 73 \\
\hline 20 & & 247.7 & 71.8 & 6.77 & 320 \\
\hline 21 & ETHYLCYCLOHEXANE & 249.3 & 330.6 & 6.92 & 1473 \\
\hline 22 & ETHYLBENZENE & 259.5 & 124.8 & 7.85 & 556 \\
\hline 24 & XYLENE & 262.6 & 266.8 & 8.13 & 1189 \\
\hline 25 & & 272.0 & 22.6 & 8.99 & 101 \\
\hline 26 & BENZALDEHYDE & 300.6 & 13.1 & 11.58 & 49 \\
\hline 27 & BIBENZYL & 520.9 & 28.3 & 32.56 & 117 \\
\hline 28 & C1-FLUORENE & 578.8 & 8.7 & 38.29 & 36 \\
\hline
\end{tabular}

RRI REPORT

$\begin{array}{llr}\text { SAMPLE: } & \text { FD635F344HT3 } & \text { TOTAL CONCENTRATION }=1567.2 \\ \text { DISK FILE: } & 33202 & \text { NO. OF INTERPRETED PEAKS }=24 \\ \text { GC RUN: } & 42486 & \text { TOTAL NO. OF PEAKS }=34\end{array}$

TOLUENE DATA:

$$
\begin{array}{ll}
\mathrm{RT}=5.76 & \text { AREA }=4449570 \\
\mathrm{ARI}=237 \% & \text { CONC }=998504
\end{array}
$$

${ }^{\text {area }}$ is in a unit that is calibrated when the standard sample is analyzed. 
TABLE D.11 Toluene Degradation Report $-635^{\circ} \mathrm{F}, 504$ h, Run 327

\begin{tabular}{|c|c|c|c|c|c|}
\hline $\begin{array}{l}\text { Peak } \\
\text { No. }\end{array}$ & Name & $\begin{array}{l}\text { Aromatic } \\
\text { Retention } \\
\text { Index }\end{array}$ & $\begin{array}{l}\text { Conc. } \\
\text { (ppm) }\end{array}$ & $\begin{array}{l}\text { Ret. } \\
\text { Time } \\
(\min )\end{array}$ & Area $^{a}$ \\
\hline 1 & & 135.8 & 5.9 & 1.66 & 31 \\
\hline 2 & BENZENE & 200.0 & 77.3 & 2.44 & 404 \\
\hline 3 & & 206.7 & 20.8 & 3.04 & 108 \\
\hline 4 & METHYLCYCLOHEXANE & 212.3 & 32.5 & 3.56 & 170 \\
\hline 5 & C2-CYCLOPENTANE & 214.9 & 4.4 & 3.79 & 23 \\
\hline 6 & C2-CYCLOPENTANE & 216.5 & 2.0 & 3.94 & 10 \\
\hline 11 & C8-ALKANE & 238.4 & 32.0 & 5.93 & 167 \\
\hline 12 & C2-CYCLOHEXANE & 238.8 & 46.4 & 5.96 & 242 \\
\hline 13 & C2-CYCLOHEXANE & 239.9 & 163.6 & 6.07 & 855 \\
\hline 14 & ISOPROPYLCYCLOPENTANE & 241.4 & 133.9 & 6.21 & 699 \\
\hline 15 & & 242.9 & 27.2 & 6.34 & 142 \\
\hline 16 & ETHYLMETHYCYCLOPENTANE & 243.9 & 5.2 & 6.43 & 27 \\
\hline 17 & ETHYLMETHYCYCLOPENTANE & 244.6 & 15.3 & 6.50 & 80 \\
\hline 18 & & 246.0 & 55.2 & 6.62 & 288 \\
\hline 19 & DIMETHYLCYCLOHEXANE & 247.3 & 16.0 & 6.74 & 83 \\
\hline 20 & & 248.2 & 69.6 & 6.82 & 364 \\
\hline 21 & ETHYLCYCLOHEXANE & 249.8 & 321.0 & 6.97 & 1677 \\
\hline 22 & ETHYLBENZENE & 259.9 & 115.4 & 7.89 & 603 \\
\hline 23 & XYLENE & 263.0 & 247.1 & 8.16 & 1291 \\
\hline 24 & & 272.3 & 22.7 & 9.01 & 101 \\
\hline 25 & BENZALDEHYDE & 300.7 & 39.4 & 11.60 & 175 \\
\hline 26 & BIBENZYL & 520.9 & 30.8 & 32.57 & 154 \\
\hline 27 & C1-FLUORENE & 578.9 & 7.6 & 38.30 & 38 \\
\hline
\end{tabular}

RRI REPORT

SAMPLE: FD635F512HT3 TOTAL CONCENTRATION $=1491.4$

DISK FILE: 32702 NO. OF INTERPRETED PEAKS $=24$

GC RUN: 42486 TOTAL NO. OF PEAKS $=27$

TOLUENE DATA:

$$
\begin{array}{ll}
\mathrm{RT}=5.72 & \text { AREA }=5216190 \\
\mathrm{ARI}=236 \% & \text { CONC }=998509
\end{array}
$$

${ }^{a}$ Area is in a unit that is calibrated when the standard sample is analyzed. 
TABLE D.12 Toluene Degradation Report $-635^{\circ} \mathrm{F}, 504 \mathrm{~h}$, Run 335

\begin{tabular}{rlrrrr}
\hline & & $\begin{array}{c}\text { Aromatic } \\
\text { Retention } \\
\text { Index }\end{array}$ & $\begin{array}{r}\text { Conc. } \\
\text { (ppm) }\end{array}$ & $\begin{array}{l}\text { Ret. } \\
\text { Time } \\
\text { (min) }\end{array}$ & Area \\
\hline & & Name & & & \\
1 & & 136.2 & 6.0 & 1.66 & 29 \\
2 & BENZENE & 200.0 & 81.3 & 2.43 & 392 \\
3 & & 206.7 & 1.3 & 3.05 & 6 \\
4 & METHYLCYCLOHEXANE & 212.4 & 8.8 & 3.56 & 42 \\
5 & METHYLCYCLOHEXANE & 212.8 & 23.8 & 3.60 & 115 \\
6 & C2-CYCLOPENTANE & 215.0 & 4.3 & 3.80 & 21 \\
7 & C2-CYCLOPENTANE & 216.5 & 2.0 & 3.93 & 9 \\
12 & C8-ALKANE & 237.9 & 32.6 & 5.88 & 158 \\
13 & C8-ALKANE & 238.3 & 46.8 & 5.92 & 225 \\
14 & C2-CYCLOHEXANE & 239.5 & 163.9 & 6.03 & 789 \\
15 & ISOPROPYLCYCLOPENTANE & 241.1 & 133.8 & 6.17 & 645 \\
16 & & 242.6 & 27.2 & 6.31 & 131 \\
17 & ETHYLMETHYCYCLOPENTANE & 243.6 & 5.2 & 6.40 & 25 \\
18 & ETHYLMETHYCYCLOPENTANE & 244.3 & 15.3 & 6.47 & 74 \\
19 & & 245.7 & 55.3 & 6.59 & 266 \\
20 & DIMETHYLCYCLOHEXANE & 247.1 & 15.9 & 6.72 & 77 \\
21 & & 248.0 & 70.0 & 6.80 & 337 \\
22 & ETHYLCYCLOHEXANE & 249.6 & 322.1 & 6.94 & 1552 \\
23 & ETHYLBNZENE & 259.7 & 116.7 & 7.87 & 562 \\
24 & XYLENE & 262.8 & 249.6 & 8.15 & 1202 \\
25 & & 272.2 & 20.4 & 9.00 & 98 \\
26 & BENZALDEHYDE & 300.7 & 48.6 & 11.59 & 194 \\
27 & DIPHENYLETHER & 481.1 & 3.9 & 28.64 & 17 \\
28 & BIBENZYL & 520.9 & 34.5 & 32.57 & 151 \\
29 & C1-FLUORENE & 578.8 & 9.0 & 38.30 & 40 \\
& & & & & \\
\hline & & & & & \\
\end{tabular}

RRI REPORT

SAMPLE: FD635F512HT

DISK FILE: 33502

GC RUN: $\quad 42986$
TOTAL CONCENTRATION $=1498.2$

NO. OF INTERPRETED PEAKS $=26$

TOTAL NO. OF PEAKS $=29$

TOLUENE DATA:

$$
\begin{array}{ll}
\mathrm{RT}=5.81 & \text { AREA }=4809310 \\
\mathrm{ARI}=237 \% & \mathrm{CONC}=998502
\end{array}
$$

area is in a unit that is calibrated when the standard sample is analyzed. 
TABLE D.13 Toluene Degradation Report - $635^{\circ} \mathrm{F}, 649 \mathrm{~h}$, Run 325

\begin{tabular}{|c|c|c|c|c|c|}
\hline $\begin{array}{c}\text { Peak } \\
\text { No. }\end{array}$ & Name & $\begin{array}{l}\text { Aromatic } \\
\text { Retention } \\
\text { Index }\end{array}$ & $\begin{array}{l}\text { Conc. } \\
\text { (ppm) }\end{array}$ & $\begin{array}{l}\text { Ret. } \\
\text { Time } \\
\text { (min) }\end{array}$ & Area ${ }^{a}$ \\
\hline 1 & & 136.0 & 3.1 & 1.66 & 13 \\
\hline 2 & BENZENE & 200.0 & 70.0 & 2.44 & 299 \\
\hline 3 & & 206.8 & 19.4 & 3.05 & 83 \\
\hline 4 & METHYLCYCLOHEXANE & 212.4 & 30.9 & 3.56 & 132 \\
\hline 5 & C2-CYCLOPENTANE & 215.1 & 2.8 & 3.81 & 12 \\
\hline 6 & C2-CYCLOPENTANE & 216.5 & 1.0 & 3.94 & 4 \\
\hline 10 & C8-ALRANE & 237.2 & 33.7 & 5.82 & 144 \\
\hline 11 & C8-ALKANE & 237.7 & 48.0 & 5.87 & 205 \\
\hline 12 & C2-CYCLOHEXANE & 239.0 & 165.8 & 5.99 & 709 \\
\hline 13 & ISOPROPYLCYCLOPENTANE & 240.6 & 135.4 & 6.13 & 579 \\
\hline 14 & ISOPROPYLCYCLOPENTANE & 242.2 & 27.6 & 6.28 & 118 \\
\hline 15 & & 243.3 & 5.2 & 6.37 & 22 \\
\hline 16 & ETHYLMETHYCYCLOPENTANE & 244.0 & 15.5 & 6.44 & 66 \\
\hline 17 & & 245.5 & 55.8 & 6.57 & 239 \\
\hline 18 & DIMETHYLCYCLOHEXANE & 246.8 & 16.0 & 6.69 & 69 \\
\hline 19 & & 247.7 & 70.6 & 6.77 & 302 \\
\hline 20 & ETHYLCYCLOHEXANE & 249.3 & 326.4 & 6.92 & 1395 \\
\hline 21 & ETHYLBENZENE & 259.6 & 118.4 & 7.86 & 506 \\
\hline 22 & XYLENE & 262.7 & 253.7 & 8.14 & 1085 \\
\hline 23 & & 272.1 & 20.7 & 9.00 & 88 \\
\hline 24 & BENZALDEHYDE & 300.7 & 18.1 & 11.59 & 66 \\
\hline 25 & BIBENZYL & 520.9 & 44.6 & 32.57 & 179 \\
\hline 26 & Cl-ELUORENE & 578.9 & 5.8 & 38.31 & 23 \\
\hline
\end{tabular}

RRI REPORT

$\begin{array}{llr}\text { SAMPLE: } & \text { FD635F657HT3 } & \text { TOTAL CONCENTRATION }=1488.5 \\ \text { DISK FILE: } & 32502 & \text { NO. OF INTERPRETED PEAKS }=24 \\ \text { GC RUN: } & 42386 & \text { TOTAL NO. OF PEAKS }=26\end{array}$

TOLUENE DATA:

$$
\begin{array}{ll}
\mathrm{RT}=5.74 & \mathrm{AREA}=4269080 \\
\mathrm{ARI}=236 \% & \mathrm{CONC}=998512
\end{array}
$$

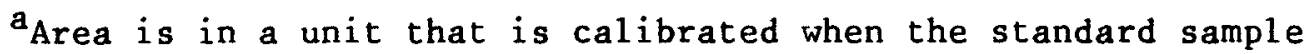
is analyzed. 
TABLE D.14 Toluene Degradation Report $-635^{\circ} \mathrm{F}, 649 \mathrm{~h}$, Run 336

\begin{tabular}{|c|c|c|c|c|c|}
\hline $\begin{array}{c}\text { Peak } \\
\text { No. }\end{array}$ & Name & $\begin{array}{c}\text { Aromatic } \\
\text { Retention } \\
\text { Index }\end{array}$ & $\begin{array}{l}\text { Conc. } \\
\text { (ppm) }\end{array}$ & $\begin{array}{l}\text { Ret. } \\
\text { Time } \\
(\min )\end{array}$ & Area $^{a}$ \\
\hline 1 & & 135.5 & 3.3 & 1.66 & 16 \\
\hline 2 & BENZENE & 200.0 & 65.2 & 2.45 & 323 \\
\hline 3 & & 206.6 & 15.5 & 3.05 & 204 \\
\hline 7 & C2-CYCLOPENTANE & 214.8 & 5.2 & 3.80 & 26 \\
\hline 6 & C2-CYCLOPENTANE & 216.3 & 3.3 & 3.93 & 16 \\
\hline 10 & C8-ALKANE & 237.9 & 32.5 & 5.90 & 161 \\
\hline 11 & C8-ALKANE & 238.3 & 46.7 & 5.93 & 231 \\
\hline 12 & C2-CYCLOHEXANE & 239.5 & 164.1 & 6.04 & 813 \\
\hline 13 & ISOPROPYLCYCLOPENTANE & 241.1 & 134.5 & 6.18 & 667 \\
\hline 14 & & 242.6 & 27.3 & 6.32 & 135 \\
\hline 15 & ETHYLMETHYCYCLOPENTANE & 243.6 & 5.2 & 6.41 & 26 \\
\hline 16 & ETHYLMETHYCYCLOPENTANE & 244.3 & 15.4 & 6.48 & 76 \\
\hline 17 & & 245.7 & 55.5 & 6.60 & 275 \\
\hline 18 & DIMETHYLCYCLOHEXANE & 247.0 & 16.1 & 6.72 & 80 \\
\hline 19 & & 247.9 & 70.3 & 6.81 & 349 \\
\hline 20 & ETHYLCYCLOHEXANE & 249.5 & 324.3 & 6.95 & 1607 \\
\hline 21 & ETHYLBENZENE & 259.7 & 117.5 & 7.87 & 582 \\
\hline 22 & XYLENE & 262.8 & 252.0 & 8.15 & 1248 \\
\hline 23 & & 272.1 & 23.8 & 9.00 & 97 \\
\hline 24 & BENZALDEHYDE & 300.6 & 19.0 & 11.59 & 78 \\
\hline 25 & DIPHENYLETHER & 481.1 & 4.0 & 28.64 & 18 \\
\hline 26 & BIBENZYL & 520.9 & 45.5 & 32.57 & 204 \\
\hline 27 & C1-ELUORENE & 578.9 & 5.9 & 38.30 & 27 \\
\hline
\end{tabular}

RRI REPORT

$\begin{array}{llr}\text { SAMPLE: } & \text { FD635F657HT3 } & \text { TOTAL CONCENTRATION }=1486.9 \\ \text { DISK FILE: } & 33602 & \text { NO. OF INTERPRETED PEAKS }=25 \\ \text { GC RUN: } & 42986 & \text { TOTAL NO. OF PEAKS }=27\end{array}$

TOLUENE DATA:

$$
\begin{array}{ll}
\mathrm{RT}=5.83 & \text { AREA }=4946760 \\
\text { ARI }=237 \% & \text { CONC }=998513
\end{array}
$$

${ }^{\text {area }}$ is in a unit that is calibrated when the standard sample is analyzed. 
TABLE D.15 Toluene Degradation Report $-635^{\circ} \mathrm{F}, 840 \mathrm{~h}$, Run 324

\begin{tabular}{|c|c|c|c|c|c|}
\hline $\begin{array}{c}\text { Peak } \\
\text { No. }\end{array}$ & Name & $\begin{array}{l}\text { Aromatic } \\
\text { Retention } \\
\quad \text { Index }\end{array}$ & $\begin{array}{l}\text { Conc. } \\
\text { (ppm) }\end{array}$ & $\begin{array}{l}\text { Ret. } \\
\text { Time } \\
\text { (min) }\end{array}$ & Area $^{a}$ \\
\hline 1 & BENZENE & 200.0 & 64.5 & 2.45 & 322 \\
\hline 2 & C2-CYCLOPENTANE & 214.9 & 1.0 & 3.81 & 5 \\
\hline 3 & C2-CYCLOPENTANE & 216.4 & 0.6 & 3.94 & 3 \\
\hline 7 & C8-ALKANE & 238.0 & 32.4 & 5.90 & 162 \\
\hline 8 & C8-ALKANE & 238.4 & 47.0 & 5.94 & 235 \\
\hline 9 & C2-CYCLOHEXANE & 239.6 & 164.7 & 6.05 & 822 \\
\hline 10 & ISOPROPYLCYCLOPENTANE & 241.1 & 135.2 & 6.19 & 674 \\
\hline 11 & & 242.6 & 27.5 & 6.33 & 137 \\
\hline 12 & ETHYLMETHYCYCLOPENTANE & 243.6 & 5.2 & 6.41 & 26 \\
\hline 13 & ETHYLMETHYCYCLOPENTANE & 244.4 & 15.5 & 6.48 & 77 \\
\hline 14 & & 245.8 & 55.6 & 6.61 & 277 \\
\hline 15 & DIMETHYLCYCLOHEXANE & 247.1 & 16.1 & 6.73 & 80 \\
\hline 16 & & 248.0 & 70.6 & 6.81 & 352 \\
\hline 17 & ETHYLCYCLOHEXANE & 249.6 & 325.7 & 6.96 & 1625 \\
\hline 18 & ETHYLBENZENE & 259.7 & 117.9 & 7.88 & 588 \\
\hline 19 & XYLENE & 262.8 & 253.2 & 8.16 & 1263 \\
\hline 20 & & 272.2 & 24.1 & 9.01 & 102 \\
\hline 21 & BENZALDEHYDE & 300.6 & 16.0 & 11.60 & 68 \\
\hline 22 & DIPHENYLETHER & 481.1 & 3.5 & 28.64 & 17 \\
\hline 23 & BIBENZYL & 520.9 & 48.8 & 32.58 & 229 \\
\hline 24 & Cl-FLUORENE & 578.9 & 8.1 & 38.31 & 38 \\
\hline
\end{tabular}

RRI REPORT

$\begin{array}{llr}\text { SAMPLE: } & \text { FD635F847HT3 } & \text { TOTAL CONCENTRATION }=1433.6 \\ \text { DISK FILE: } & 32402 & \text { NO. OF INTERPRETED PEAKS }=22 \\ \text { GC RUN: } & 42386 & \text { TOTAL NO. OF PEAKS }=24\end{array}$

TOLUENE DATA:

$$
\begin{array}{ll}
\mathrm{RT}=5.83 & \text { AREA }=4980520 \\
\mathrm{ARI}=237 \% & \text { CONC }=998566
\end{array}
$$

${ }^{a}$ Area is in a unit that is calibrated when the standard sample is analyzed. 
TABLE D.16 Toluene Degradation Report - $635^{\circ} \mathrm{F}, 840$ h, Run 346

\begin{tabular}{|c|c|c|c|c|c|}
\hline $\begin{array}{c}\text { Peak } \\
\text { No. }\end{array}$ & Name & $\begin{array}{l}\text { Aromatic } \\
\text { Retention } \\
\text { Index }\end{array}$ & $\begin{array}{l}\text { Conc. } \\
\text { (ppm) }\end{array}$ & $\begin{array}{l}\text { Ret. } \\
\text { Time } \\
\text { (min) }\end{array}$ & Area $^{a}$ \\
\hline 1 & BENZENE & 200.0 & 66.6 & 2.41 & 367 \\
\hline 2 & & 206.8 & 2.5 & 3.03 & 14 \\
\hline 3 & C2-CYCLOPENTANE & 214.6 & 0.5 & 3.73 & 3 \\
\hline 7 & C2-CYCLOHEXANE & 238.9 & 31.3 & 5.92 & 173 \\
\hline 8 & C2-CYCLOHEXANE & 239.3 & 46.6 & 5.96 & 257 \\
\hline 9 & C2-CYCLOHEXANE & 240.4 & 165.7 & 6.05 & 913 \\
\hline 10 & ISOPROPYLCYCLOPENTANE & 241.8 & 136.8 & 6.18 & 754 \\
\hline 11 & & 243.2 & 27.9 & 6.31 & 153 \\
\hline 12 & ETHYLMETHYCYCLOPENTANE & 244.1 & 5.2 & 6.39 & 29 \\
\hline 13 & ETHYLMETHYCYCLOPENTANE & 244.9 & 15.8 & 6.46 & 87 \\
\hline 14 & & 246.2 & 56.8 & 6.58 & 313 \\
\hline 15 & & 247.5 & 16.4 & 6.70 & 90 \\
\hline 16 & & 248.4 & 72.2 & 6.78 & 398 \\
\hline 17 & ETHYLCYCLOHEXANE & 249.9 & 331.4 & 6.92 & 1826 \\
\hline 18 & ETHYLBENZENE & 260.0 & 120.4 & 7.82 & 663 \\
\hline 19 & XYLENE & 263.0 & 259.7 & 8.10 & 1431 \\
\hline 20 & & 272.3 & 21.8 & 8.93 & 120 \\
\hline 21 & BENZALDEHYDE & 300.6 & 18.6 & 11.49 & 91 \\
\hline 22 & DIPHENYLETHER & 481.0 & 3.8 & 28.44 & 20 \\
\hline 23 & BIBENZYL & 520.9 & 49.1 & 32.36 & 265 \\
\hline 24 & C1-FLUORENE & 578.8 & 8.2 & 38.07 & 44 \\
\hline
\end{tabular}

RRI REPORT

$\begin{array}{llr}\text { SAMPLE: } & \text { FD635F847HT3 } & \text { TOTAL CONCENTRATION }=1457.2 \\ \text { DISK FILE: } & 34602 & \text { NO. OF INTERPRETED PEAKS }=22 \\ \text { GC RUN: } & 52986 & \text { TOTAL NO. OF PEAKS }=24\end{array}$

TOLUENE DATA:

$$
\begin{array}{ll}
\text { RT }=5.87 & \text { AREA }=5502150 \\
\text { ARI }=238 \% & \text { CONC }=998543
\end{array}
$$

${ }^{\text {Area }}$ is in a unit that is calibrated when the standard sample is analyzed. 
TABLE D.17 Toluene Degradation Report $-600^{\circ} \mathrm{F}, 0 \mathrm{~h}$, Run 313

\begin{tabular}{|c|c|c|c|c|c|}
\hline $\begin{array}{c}\text { Peak } \\
\text { No. }\end{array}$ & Name & $\begin{array}{l}\text { Aromatic } \\
\text { Retention } \\
\quad \text { Index }\end{array}$ & $\begin{array}{l}\text { Conc, } \\
\text { (ppm) }\end{array}$ & $\begin{array}{l}\text { Ret. } \\
\text { Time } \\
(\min )\end{array}$ & Area ${ }^{a}$ \\
\hline 3 & PROPYLETHYLETHER & 149.0 & 13.8 & 1.82 & 55 \\
\hline 4 & THF & 162.7 & 4.8 & 1.98 & 29 \\
\hline 5 & BENZENE & 200.0 & 126.8 & 2.44 & 505 \\
\hline 6 & $\mathrm{C} 6 \mathrm{H} 14$ & 201.7 & 23.8 & 2.59 & 95 \\
\hline 7 & & 206.9 & 15.0 & 3.06 & 60 \\
\hline 8 & METHYLCYCLOHEXANE & 212.6 & 32.2 & 3.58 & 128 \\
\hline 9 & C2-CYCLOPENTANE & 215.1 & 8.5 & 3.81 & 34 \\
\hline 11 & C8-ALKANE & 237.2 & 23.5 & 5.82 & 94 \\
\hline 12 & C8-ALKANE & 237.6 & 43.5 & 5.86 & 173 \\
\hline 13 & C2-CYCLOHEXANE & 239.0 & 139.3 & 5.99 & 555 \\
\hline 14 & ISOPROPYLCYCLOPENTANE & 240.6 & 107.2 & 6.13 & 427 \\
\hline 15 & ISOPROPYLCYCLOPENTANE & 242.2 & 21.5 & 6.27 & 86 \\
\hline 16 & & 243.2 & 5.1 & 6.36 & 20 \\
\hline 17 & ETHYLMETHYCYCLOPENTANE & 244.0 & 11.6 & 6.43 & 46 \\
\hline 18 & ETHYLMETHYCYCLOPENTANE & 245.4 & 48.3 & 6.57 & 193 \\
\hline 19 & DIMETHYLCYCLOHEXANE & 246.8 & 10.7 & 6.69 & 43 \\
\hline 20 & & 247.7 & 53.4 & 6.77 & 213 \\
\hline 21 & ETHYLCYCLOHEXANE & 249.3 & 235.5 & 6.92 & 938 \\
\hline 22 & ETHYLBENZENE & 259.6 & 98.7 & 7.85 & 393 \\
\hline 23 & XYLENE & 262.7 & 138.6 & 8.13 & 552 \\
\hline 24 & & 272.1 & 9.4 & 8.99 & 37 \\
\hline 25 & DOWTHERM/C1-BIPHENYL & 481.2 & 5.9 & 28.65 & 23 \\
\hline
\end{tabular}

RRI REPORT

$\begin{array}{llr}\text { SAMPLE: } & \text { FD6OOFOHTS } & \text { TOTAL CONCENTRATION }=1177.4 \\ \text { DISK FILE: } & 31302 & \text { NO. OF INTERPRETED PEAKS }=23 \\ \text { GC RUN: } & 41586 & \text { TOTAL NO. OF PEAKS }=25\end{array}$

TOLUENE DATA:

$$
\begin{array}{ll}
\mathrm{RT}=5.74 & \text { AREA }=3979470 \\
\mathrm{ARI}=236 \% & \mathrm{CONC}=998823
\end{array}
$$

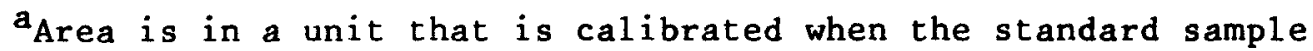
is analyzed. 
TABLE D.18 Toluene Degradation Report $-600^{\circ} \mathrm{F}, 23 \mathrm{~h}$, Run 239

\begin{tabular}{rlrrrr}
\hline $\begin{array}{c}\text { Peak } \\
\text { No. }\end{array}$ & Name & $\begin{array}{c}\text { Aromatic } \\
\text { Retention } \\
\text { Index }\end{array}$ & $\begin{array}{r}\text { Conc. } \\
(\mathrm{ppm})\end{array}$ & $\begin{array}{l}\text { Ret. } \\
\text { Time } \\
\text { (min) }\end{array}$ & Area $^{\text {a }}$ \\
\hline & & 101.7 & 7.4 & 1.24 & 25 \\
1 & PROPYLETHYLTHER & 148.6 & 10.1 & 1.82 & 34 \\
2 & BENZENE & 200.0 & 109.4 & 2.44 & 374 \\
3 & C6H14 & 201.7 & 17.1 & 2.60 & 59 \\
4 & & 206.8 & 13.5 & 3.06 & 46 \\
5 & METHYLCYCLOHEXANE & 212.4 & 30.8 & 3.58 & 106 \\
6 & 215.1 & 8.6 & 3.82 & 30 \\
7 & C2-CYCLOPENTANE & 236.6 & 27.2 & 5.78 & 93 \\
10 & C8-ALKANE & 237.1 & 42.3 & 5.82 & 145 \\
11 & C8-ALKANE & 237.8 & 10.1 & 5.88 & 35 \\
12 & C8-ALKANE & 238.6 & 128.9 & 5.95 & 441 \\
13 & C2-CYCLOHEXANE & 240.1 & 106.1 & 6.10 & 363 \\
14 & C2-CYCLOHEXANE & 241.8 & 21.2 & 6.24 & 73 \\
15 & ISOPROPYLCYCLOPENTANE & 242.8 & 5.2 & 6.34 & 18 \\
16 & & 480.9 & 7.2 & 28.65 & 23 \\
26 & DOWTHERM/C1-BIPHENYL & 520.8 & 7.1 & 32.60 & 23 \\
27 & BIBENZYL & & & & \\
\hline
\end{tabular}

RRI REPORT

SAMPLE: FD600F46HT5

DISK FILE: 23902

GC RUN: $\quad 4886$

TOLUENE DATA:

$$
\begin{array}{ll}
\text { RT }=5.69 & \text { AREA }=3417050 \\
\text { ARI }=236 \% & \text { CONC }=998823
\end{array}
$$

$$
\begin{array}{r}
\text { TOTAL CONCENTRATION }=1177.2 \\
\text { NO. OF INTERPRETED PEAKS }=26 \\
\text { TOTAL NO. OF PEAKS }=27
\end{array}
$$


TABLE D.19 Toluene Degradation Report $-600^{\circ} \mathrm{F}, 266$ h, Run 230

\begin{tabular}{|c|c|c|c|c|c|}
\hline $\begin{array}{l}\text { Peak } \\
\text { No. }\end{array}$ & Name & $\begin{array}{l}\text { Aromatic } \\
\text { Retention } \\
\text { Index }\end{array}$ & $\begin{array}{l}\text { Conc. } \\
\text { (ppm) }\end{array}$ & $\begin{array}{l}\text { Ret. } \\
\text { Time } \\
\text { (min) }\end{array}$ & Area ${ }^{a}$ \\
\hline 1 & & 148.1 & 5.2 & 1.82 & 27 \\
\hline 2 & BENZENE & 200.0 & 106.6 & 2.45 & 565 \\
\hline 3 & C2-CYCLOPENTANE & 214.8 & .2 & 3.80 & 1 \\
\hline 6 & C2-CYCLOHEXANE & 238.7 & 26.3 & 5.97 & 139 \\
\hline 7 & C2-CYCLOHEXANE & 239.0 & 42.5 & 6.00 & 225 \\
\hline 8 & C2-CYCLOHEXANE & 240.1 & 142.6 & 6.11 & 756 \\
\hline 9 & I SOPROPYLCYCLOPENTANE & 241.6 & 108.1 & 6.24 & 573 \\
\hline 10 & & 243.1 & 22.1 & 6.37 & 117 \\
\hline 11 & ETHYLMETHYCYCLOPENTANE & 244.0 & 4.9 & 6.45 & 26 \\
\hline 12 & ETHYLMETHYCYCLOPENTANE & 244.7 & 11.7 & 6.52 & 62 \\
\hline 13 & & 246.1 & 48.9 & 6.65 & 259 \\
\hline 14 & DIMETHYLCYCLOHEXANE & 247.4 & 11.1 & 6.77 & 59 \\
\hline 15 & & 248.3 & 55.1 & 6.84 & 292 \\
\hline 16 & ETHYLCYCLOHEXANE & 249.8 & 241.8 & 6.99 & 1282 \\
\hline 17 & ETHYLBENZENE & 259.9 & 102.3 & 7.90 & 543 \\
\hline 18 & XYLENE & 263.0 & 160.0 & 8.18 & 848 \\
\hline 19 & & 272.3 & 13.2 & 9.03 & 61 \\
\hline 20 & BENZALDEHYDE & 300.7 & 7.2 & 11.62 & 33 \\
\hline 21 & DOWTHERM/C1-BIPHENYL & 481.1 & 7.2 & 28.66 & 37 \\
\hline 22 & BIBENZYL & 520.8 & 21.6 & 32.59 & 109 \\
\hline
\end{tabular}

RRI REPORT

$\begin{array}{llr}\text { SAMPLE: } & \text { FD600F266HT5 } & \text { TOTAL CONCENTRATION }=1138.7 \\ \text { DISK FILE: } & 23002 & \text { NO. OF INTERPRETED PEAKS }=21 \\ \text { GC RUN: } & 4384 & \text { TOTAL NO. OF PEAKS }=22\end{array}$

TOLUENE DATA:

$$
\begin{array}{ll}
\mathrm{RT}=5.91 & \text { AREA }=5295500 \\
\mathrm{ARI}=238 \% & \mathrm{CONC}=998861
\end{array}
$$

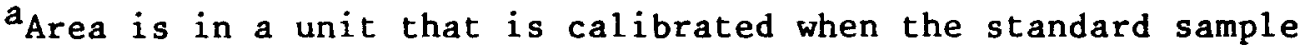
is analyzed.
} 
TABLE D.20 Toluene Degradation Report $-600^{\circ} \mathrm{F}, 455$ h, Run 232

\begin{tabular}{|c|c|c|c|c|c|}
\hline $\begin{array}{c}\text { Peak } \\
\text { No. }\end{array}$ & Name & $\begin{array}{l}\text { Aromatic } \\
\text { Retention } \\
\quad \text { Index }\end{array}$ & $\begin{array}{l}\text { Conc, } \\
\text { (ppm) }\end{array}$ & $\begin{array}{l}\text { Ret. } \\
\text { Time } \\
\text { (min) }\end{array}$ & Area $^{a}$ \\
\hline 1 & BENZENE & 200.0 & 99.8 & 2.44 & 628 \\
\hline 2 & METHYLCYCLOHEXANE & 212.4 & 6.4 & 3.56 & 41 \\
\hline 3 & C2-CYCLOPENTANE & 214.9 & 9.7 & 3.79 & 61 \\
\hline 6 & C2-CYCLOHEXANE & 240.0 & 24.7 & 6.08 & 155 \\
\hline 7 & C2-CYCLOHEXANE & 240.3 & 41.6 & 6.11 & 261 \\
\hline 8 & ISOPROPYLCYCLOPENTANE & 241.3 & 141.6 & 6.20 & 890 \\
\hline 9 & & 242.7 & 107.8 & 6.32 & 678 \\
\hline 10 & ETHYLMETHYCYCLOPENTANE & 244.0 & 22.1 & 6.45 & 139 \\
\hline 11 & ETHYLMETHYCYCLOPENTANE & 244.9 & 4.7 & 6.52 & 29 \\
\hline 12 & & 245.6 & 11.7 & 6.59 & 74 \\
\hline 13 & DIMETHYLCYCLOHEXANE & 246.9 & 48.6 & 6.71 & 306 \\
\hline 14 & & 248.2 & 11.0 & 6.83 & 69 \\
\hline 15 & & 249.0 & 55.5 & 6.90 & 349 \\
\hline 16 & ETHYLCYCLOHEXANE & 250.6 & 243.7 & 7.04 & 1533 \\
\hline 17 & ETHYLBENZENE & 260.5 & 102.7 & 7.94 & 646 \\
\hline 18 & XYLENE & 263.5 & 164.1 & 8.21 & 1032 \\
\hline 19 & & 272.7 & 13.8 & 9.06 & 75 \\
\hline 20 & BENZALDEHYDE & 300.9 & 9.3 & 11.63 & 51 \\
\hline 21 & DOWTHERM/CI-BIPHENYL & 481.0 & 7.7 & 28.65 & 47 \\
\hline 22 & BIBENZYL & 520.8 & 32.8 & 32.60 & 196 \\
\hline 23 & C1-FLUORENE & 578.8 & 4.4 & 38.33 & 27 \\
\hline
\end{tabular}

RRI REPORT

$\begin{array}{llr}\text { SAMPLE: } & \text { ED600F455HT5 } & \text { TOTAL CONCENTRATION }=1164 \\ \text { DISK FILE: } & 23202 & \text { NO. OF INTERPRETED PEAKS }=22 \\ \text { GC RUN: } & 4386 & \text { TOTAL NO. OF PEAKS }=23\end{array}$

TOLUENE DATA:

$$
\begin{array}{ll}
\mathrm{RT}=5.97 & \text { AREA }=6280080 \\
\mathrm{ARI}=239 \% & \text { CONC }=998836
\end{array}
$$

${ }^{a}$ Area is in a unit that is calibrated when the standard sample is analyzed. 
TABLE D.21 Toluene Degradation Report - $600^{\circ}$ F, 623 h, Run 236

\begin{tabular}{|c|c|c|c|c|c|}
\hline $\begin{array}{c}\text { Peak } \\
\text { No. }\end{array}$ & Name & $\begin{array}{l}\text { Aromatic } \\
\text { Retention } \\
\text { Index }\end{array}$ & $\begin{array}{l}\text { Conc. } \\
\text { (ppm) }\end{array}$ & $\begin{array}{l}\text { Ret. } \\
\text { Time } \\
\text { (min) }\end{array}$ & Area ${ }^{a}$ \\
\hline 1 & BENZENE & 200.0 & 90.6 & 2.43 & 707 \\
\hline 2 & C2-CYCLOPENTANE & 215.0 & .8 & 3.80 & 7 \\
\hline 5 & ISOPROPYLCYCLOPENTANE & 241.9 & 62.5 & 6.25 & 489 \\
\hline 6 & & 242.7 & 140.0 & 6.33 & 1094 \\
\hline 7 & ETHYLMETHYCYCLOPENTANE & 244.0 & 106.9 & 6.44 & 835 \\
\hline 8 & ETHYLMETHYCYCLOPENTANE & 245.2 & 22.1 & 6.55 & 173 \\
\hline 9 & & 245.9 & 4.3 & 6.61 & 33 \\
\hline 10 & DIMETHYLCYCLOHEXANE & 246.7 & 11.5 & 6.68 & 90 \\
\hline 11 & & 247.9 & 48.6 & 6.80 & 380 \\
\hline 12 & & 249.2 & 10.4 & 6.91 & 82 \\
\hline 13 & ETHYLCYCLOHEXANE & 250.0 & 56.4 & 6.98 & 441 \\
\hline 14 & ETHYLCYCLOHEXANE & 251.4 & 247.0 & 7.12 & 1931 \\
\hline 15 & ETHYLBENZENE & 261.1 & 106.8 & 7.99 & 835 \\
\hline 16 & XYLENE & 264.0 & 170.6 & 8.26 & 1334 \\
\hline 17 & & 273.1 & 14.6 & 9.09 & 100 \\
\hline 18 & BENZALDEHYDE & 301.2 & 11.8 & 11.64 & 80 \\
\hline 19 & BIPHENYL & 473.0 & 2.9 & 27.86 & 22 \\
\hline 20 & DOWTHERM/C1-BIPHENYL & 481.0 & 7.8 & 28.66 & 60 \\
\hline 21 & BIBENZYL & 520.9 & 40.2 & 32.60 & 309 \\
\hline 22 & C2-BIPHENYL & 542.8 & 2.4 & 34.77 & 18 \\
\hline 23 & CI-FLUORENE & 578.8 & 5.1 & 38.33 & 39 \\
\hline
\end{tabular}

RRI REPORT

$\begin{array}{llr}\text { SAMPLE: } & \text { FD600F622HT5 } & \text { TOTAL CONCENTRATION }=1163.5 \\ \text { DISK FILE: } & 23602 & \text { NO. OF INTERPRETED PEAKS }=22 \\ \text { GC RUN: } & 4484 & \text { TOTAL NO. OF PEAKS }=23\end{array}$

TOLUENE DATA:

$$
\begin{array}{ll}
\mathrm{RT}=5.75 & \text { AREA }=7806880 \\
\mathrm{ARI}=236 \% & \text { CONC }=998837
\end{array}
$$

${ }^{\text {Area }}$ is in a unit that is calibrated when the standard sample is analyzed. 
TABLE D.22 Toluene Degradation Report - 600 F, 766 h, Run 229

\begin{tabular}{|c|c|c|c|c|c|}
\hline $\begin{array}{c}\text { Peak } \\
\text { No. }\end{array}$ & Name & $\begin{array}{c}\text { Aromatic } \\
\text { Retention } \\
\text { Index }\end{array}$ & $\begin{array}{l}\text { Conc. } \\
\text { (ppm) }\end{array}$ & $\begin{array}{l}\text { Ret. } \\
\text { Time } \\
\text { (min) }\end{array}$ & Area \\
\hline 1 & BENZENE & 200.0 & 93.7 & 2.45 & 591 \\
\hline 2 & & 206.7 & 0.9 & 3.06 & 6 \\
\hline 3 & METHYLCYCLOHEXANE & 212.3 & 0.5 & 3.57 & 3 \\
\hline 4 & C2-CYCLOPENTANE & 214.8 & 0.5 & 3.79 & 3 \\
\hline 7 & C2-CYCLOHEXANE & 239.9 & 24.6 & 6.08 & 155 \\
\hline 8 & C2-CYCLOHEXANE & 240.2 & 42.3 & 6.11 & 267 \\
\hline 9 & ISOPROPYLCYCLOPENTANE & 241.2 & 142.2 & 6.20 & 897 \\
\hline 10 & & 242.6 & 107.3 & 6.32 & 677 \\
\hline 11 & ETHYLMETHYCYCLOPENTANE & 243.9 & 22.2 & 6.45 & 140 \\
\hline 12 & ETHYLMETHYCYCLOPENTANE & 244.8 & 4.4 & 6.52 & 28 \\
\hline 13 & & 245.5 & 11.8 & 6.59 & 74 \\
\hline 14 & DIMETHYLCYCLOHEXANE & 246.8 & 48.3 & 6.71 & 305 \\
\hline $\begin{array}{l}14 \\
15\end{array}$ & DIME INTLCICLUELAANE & 248.1 & $\begin{array}{l}40.0 \\
11.0\end{array}$ & 6.83 & 70 \\
\hline 16 & & 248.9 & 55.4 & 6.90 & 350 \\
\hline 17 & ETHYLCYCLOHEXANE & 250.5 & 244.8 & 7.04 & 1544 \\
\hline 18 & ETHYLBENZENE & 260.4 & 104.8 & 7.94 & 661 \\
\hline 19 & XYLENE & 263.4 & 167.5 & 8.22 & 1056 \\
\hline 20 & & 272.6 & 14.2 & 9.05 & 78 \\
\hline 21 & BENZALDEHYDE & 300.8 & 12.5 & 11.62 & 68 \\
\hline 22 & BIPHENYL & 473.0 & 2.8 & 27.86 & 17 \\
\hline 23 & DOWTHERM/CI-BIPHENYL & 481.0 & 8.3 & 28.65 & 50 \\
\hline 24 & BIBENZYL & 520.8 & 50.4 & 32.59 & 303 \\
\hline 25 & Cl-FLUORENE & 578.8 & 6.0 & 38.32 & 36 \\
\hline
\end{tabular}

RRI REPORT

$\begin{array}{llr}\text { SAMPLE: } & \text { FD600F768HT5 } & \text { TOTAL CONCENTRATION }=1176 \\ \text { DISK FILE: } & 22902 & \text { NO. OF INTERPRETED PEAKS }=24 \\ \text { GC RUN: } & 4384 & \text { TOTAL NO. OF PEAKS }=25\end{array}$

TOLUENE DATA:

$$
\begin{array}{ll}
\mathrm{RT}=6.03 & \text { AREA }=6301120 \\
\mathrm{ARI}=239 \% & \text { CONC }=998824
\end{array}
$$

${ }^{\text {area }}$ is in a unit that is calibrated when the standard sample is anslyzed. 
TABLE D.23 Toluene Degradation Report $-600^{\circ} \mathrm{F}, 938$ h, Run 228

\begin{tabular}{|c|c|c|c|c|c|}
\hline $\begin{array}{c}\text { Peak } \\
\text { No. }\end{array}$ & Name & $\begin{array}{l}\text { Aromatic } \\
\text { Retention } \\
\quad \text { Index }\end{array}$ & $\begin{array}{l}\text { Conc. } \\
\text { (ppm) }\end{array}$ & $\begin{array}{l}\text { Ret. } \\
\text { Time } \\
\text { (min) }\end{array}$ & Area ${ }^{a}$ \\
\hline 1 & BENZENE & 200.0 & 92.5 & 2.44 & 419 \\
\hline 2 & & 206.9 & 12.9 & 3.07 & 58 \\
\hline 3 & MEHTYLCYCLOHEXANE & 212.6 & 29.9 & 3.59 & 135 \\
\hline 4 & C2-CYCLOPENTANE & 215.1 & 8.3 & 3.81 & 38 \\
\hline 5 & C2-CYCLOPENTANE & 216.4 & 11.0 & 3.93 & 49 \\
\hline 8 & C8-ALKANE & 238.2 & 73.5 & 5.92 & 333 \\
\hline 9 & C2-CYCLOHEXANE & 239.4 & 144.5 & 6.03 & 654 \\
\hline 10 & ISOPROPYLCYCLOPENTANE & 240.9 & 107.5 & 6.17 & 487 \\
\hline 11 & & 242.5 & 22.3 & 6.31 & 101 \\
\hline 12 & ETHYLMETHYCYCLOPENTANE & 243.5 & 4.5 & 6.40 & 21 \\
\hline 13 & ETHYLMETHYCYCLOPENTANE & 244.2 & 11.9 & 6.47 & 54 \\
\hline 14 & & 245.6 & 48.0 & 6.60 & 217 \\
\hline 15 & DIMETHYLCYCLOHEXANE & 247.0 & 11.2 & 6.72 & 51 \\
\hline 16 & & 247.9 & 55.2 & 6.80 & 250 \\
\hline 17 & ETHYLCYCLOHEXANE & 249.5 & 244.8 & 6.94 & 1108 \\
\hline 18 & ETHYLBENZENE & 259.7 & 105.1 & 7.87 & 476 \\
\hline 19 & XYLENE & 262.8 & 167.3 & 8.15 & 757 \\
\hline 20 & & 272.2 & 14.1 & 9.01 & 55 \\
\hline 21 & BENZALDEHYDE & 300.7 & 23.3 & 11.60 & 92 \\
\hline 22 & DOWTHERM/Cl-BIPHENYL & 481.0 & 8.6 & 28.66 & 37 \\
\hline 23 & BIBENZYL & 520.8 & 66.3 & 32.59 & 286 \\
\hline 24 & C1-FLUORENE & 578.9 & 5.7 & 38.34 & 25 \\
\hline
\end{tabular}

RRI REPORT

$\begin{array}{llr}\text { SAMPLE: } & \text { FD600F938HTS } & \text { TOTAL CONCENTRATION }=1268.7 \\ \text { DISK FILE: } & 22802 & \text { NO. OF INTERPRETED PEAKS }=23 \\ \text { GC RUN: } & 4384 & \text { TOTAL NO. OF PEAKS }=24\end{array}$

TOLUENE DATA:

$$
\begin{array}{ll}
\mathrm{RT}=5.80 & \text { AREA }=4519340 \\
\mathrm{ARI}=237 \% & \mathrm{CONC}=998731
\end{array}
$$

${ }^{\text {a Area }}$ is in a unit that is calibrated when the standard sample is analyzed. 
TABLE D.24 Toluene Degradation Report - 600 ${ }^{\circ}$ F, 1006 h, Run 234

\begin{tabular}{|c|c|c|c|c|c|}
\hline $\begin{array}{c}\text { Peak } \\
\text { No. }\end{array}$ & Name & $\begin{array}{l}\text { Aromatic } \\
\text { Retention } \\
\quad \text { Index }\end{array}$ & $\begin{array}{l}\text { Conc. } \\
\text { (ppm) }\end{array}$ & $\begin{array}{l}\text { Ret. } \\
\text { Time } \\
(\min )\end{array}$ & Area ${ }^{a}$ \\
\hline 1 & BENZENE & 200.0 & 92.9 & 2.46 & 505 \\
\hline 2 & & 206.7 & 13.0 & 3.07 & 71 \\
\hline 3 & METHYLCYCLOHEXANE & 212.4 & 28.2 & 3.59 & 153 \\
\hline 4 & C2-CYCLOPENTANE & 214.7 & 8.2 & 3.79 & 45 \\
\hline 5 & C2-CYCLOPENTANE & 216.3 & 15.2 & 3.94 & 82 \\
\hline 7 & C2-CYCLOHEXANE & 239.1 & 71.2 & 6.02 & 387 \\
\hline 8 & C2-CYCLOHEXANE & 240.3 & 142.5 & 6.12 & 774 \\
\hline 9 & ISOPROPYLCYCLOPENTANE & 241.7 & 106.9 & 6.25 & 581 \\
\hline 10 & & 243.2 & 22.1 & 6.38 & 120 \\
\hline 11 & ETHYLMETHYCYCLOPENTANE & 244.1 & 4.4 & 6.46 & 24 \\
\hline 12 & ETHYLMETHYCYCLOPENTANE & 244.8 & 11.8 & 6.53 & 64 \\
\hline 13 & & 246.2 & 48.0 & 6.65 & 261 \\
\hline 14 & & 247.5 & 11.0 & 6.77 & 60 \\
\hline 15 & & 248.3 & 55.4 & 6.85 & 301 \\
\hline 16 & ETHYLCYCLOHEXANE & 249.9 & 245.2 & 6.99 & 1332 \\
\hline 17 & ETHYLBENZENE & 260.0 & 105.4 & 7.91 & 573 \\
\hline 18 & XYLENE & 263.0 & 167.8 & 8.18 & 912 \\
\hline 19 & & 272.3 & 14.3 & 9.03 & 67 \\
\hline 20 & BENZALDEHYDE & 300.7 & 22.3 & 11.61 & 105 \\
\hline 21 & DOWTHERM/C1-BIPHENYL & 481.1 & 8.2 & 28.65 & 44 \\
\hline-22 & BIBENZYL & 520.9 & 63.6 & 32.58 & 340 \\
\hline 23 & C2-BIPHENYL & 542.9 & 3.8 & 34.75 & 20 \\
\hline 24 & C1-FLUORENE & 578.9 & 7.5 & 38.32 & 40 \\
\hline
\end{tabular}

RRI REPORT

SAMPLE: $\quad$ FD600F100HT5

DISK FILE: 23402

GC RUN: $\quad 4484$

TOLUENE DATA:

$$
\begin{array}{ll}
\mathrm{RT}=5.92 & \text { AREA }=5425390 \\
\mathrm{ARI}=238 \% & \text { CONC }=998731
\end{array}
$$

TOTAL CONCENTRATION $=1269$ NO. OF INTERPRETED PEAKS $=24$ TOTAL NO. OF PEAKS $=24$ 
TABLE D.25 Toluene Degradation Report $-650^{\circ} \mathrm{F}, 0 \mathrm{~h}$, Run 224

\begin{tabular}{rlrrrr}
\hline Peak & Name & $\begin{array}{c}\text { Aromatic } \\
\text { Retention } \\
\text { Index }\end{array}$ & $\begin{array}{r}\text { Conc. } \\
\text { (ppm) }\end{array}$ & $\begin{array}{l}\text { Ret. } \\
\text { Time } \\
\text { (min) }\end{array}$ & Area \\
\hline & PROPYLETHYLETHER & 148.9 & 6.2 & 1.86 & 27 \\
1 & BENZENE & 200.0 & 97.3 & 2.50 & 419 \\
2 & 201.8 & 4.9 & 2.66 & 21 \\
3 & C6H14 & 212.7 & 17.4 & 3.64 & 75 \\
4 & METHYLCYCLOHEXANE & 238.1 & 32.4 & 5.93 & 139 \\
7 & C8-ALKANE & 238.5 & 51.8 & 5.97 & 222 \\
8 & C2-CYCLOHEXANE & 239.9 & 156.4 & 6.09 & 672 \\
9 & C2-CYCLOHEXANE & 241.4 & 91.9 & 6.23 & 395 \\
10 & ISOPROPYLCYCLOPENTANE & 243.0 & 22.5 & 6.37 & 97 \\
11 & & 244.0 & 6.2 & 6.46 & 27 \\
12 & ETHYLMETHYCYCLOPENTANE & 244.7 & 8.1 & 6.53 & 34 \\
13 & ETHYLMETHYCYCLOPENTANE & 246.2 & 45.7 & 6.66 & 197 \\
14 & & 247.5 & 8.9 & 6.78 & 38 \\
15 & & 248.4 & 51.6 & 6.86 & 222 \\
16 & & 250.0 & 201.6 & 7.00 & 866 \\
17 & ETHYLCYCLOHEXANE & 260.4 & 129.1 & 7.94 & 554 \\
18 & ETHYLBENZENE & 263.5 & 269.3 & 8.22 & 1157 \\
19 & XYLENE & 272.9 & 14.5 & 9.07 & 99 \\
20 & & & & & \\
\hline
\end{tabular}

RRI REPORT

SAMPLE: $\quad$ FD650F

DISK FILE: 22402

GC RUN: $\quad 32584$
TOTAL CONCENTRATION $=1216$

NO. OF INTERPRETED PEAKS $=19$

TOTAL NO. OF PEAKS $=20$

TOLUENE DATA:

$$
\begin{array}{ll}
\mathrm{RT}=5.69 & \text { AREA }=4292290 \\
\mathrm{ARI}=235 \% & \text { CONC }=998784
\end{array}
$$

area is in a unit that is calibrated when the standard sample is analyzed. 
TABLE D.26 Toluene Degradation Report $-650^{\circ} \mathrm{F}, 19 \mathrm{~h}$, Run 223

\begin{tabular}{rlrrrr}
\hline $\begin{array}{r}\text { Peak } \\
\text { No. }\end{array}$ & \multicolumn{1}{c}{ Name } & $\begin{array}{c}\text { Aromatic } \\
\text { Retention } \\
\text { Index }\end{array}$ & $\begin{array}{r}\text { Conc. } \\
\text { (ppm) }\end{array}$ & $\begin{array}{l}\text { Ret. } \\
\text { Time } \\
\text { (min) }\end{array}$ & Area $^{\text {a }}$ \\
\hline & PROPYLETHYLETHER & 149.4 & 4.8 & 1.85 & 27 \\
1 & BENZENE & 200.0 & 108.5 & 2.48 & 601 \\
2 & C2-CYCLOPENTANE & 215.0 & 1.1 & 3.84 & 6 \\
3 & C2-CYCLOHEXANE & 239.2 & 30.3 & 6.04 & 168 \\
8 & 239.5 & 50.3 & 6.07 & 279 \\
9 & C2-CYCLOHEXANE & 240.6 & 155.5 & 6.17 & 862 \\
10 & ISOPROPYLCYCLOPENTANE & 242.0 & 103.7 & 6.30 & 575 \\
11 & ISOPROPYLCYCLOPENTANE & 243.4 & 22.4 & 6.43 & 124 \\
12 & & 244.3 & 5.9 & 6.51 & 33 \\
13 & ETHYLMETHYCYCLOPENTANE & 245.1 & 8.0 & 6.58 & 44 \\
14 & ETHYLMETHYCYCLOPENTANE & 246.4 & 45.0 & 6.70 & 250 \\
15 & & 247.7 & 8.5 & 6.82 & 47 \\
16 & & 248.6 & 50.9 & 6.90 & 282 \\
17 & ETHYLCYCLOHEXANE & 250.1 & 196.3 & 7.04 & 1089 \\
18 & ETHYLCYCLOHEXANE & 260.3 & 121.5 & 7.96 & 674 \\
19 & ETHYLBENZENE & 263.3 & 253.2 & 8.24 & 1404 \\
20 & XYLENE & 272.6 & 13.6 & 9.08 & 120 \\
21 & & 301.0 & 2.0 & 11.67 & 18 \\
22 & BENZALDEHYDE & 520.8 & 7.6 & 32.61 & 57 \\
23 & BIBENZYL & & & & \\
\hline
\end{tabular}

RRI REPORT

SAMPLE: $\quad$ FD650F26HT5

DISK FILE: 22302

GC RUN: $\quad 32584$
TOTAL CONCENTRATION $=1189.4$

NO. OF INTERPRETED PEAKS $=20$

TOTAL NO. OF PEAKS $=23$

TOLUENE DATA:

$$
\begin{array}{ll}
\mathrm{RT}=5.98 & \text { AREA }=5537600 \\
\mathrm{ARI}=239 \% & \text { CONC }=998811
\end{array}
$$

\footnotetext{
${ }^{a}$ Area is in a unit that is calibrated when the standard sample
} is analyzed. 
TABLE D.27 Toluene Degradation Report $-650^{\circ} \mathrm{F}, 115$ h, Run 222

\begin{tabular}{|c|c|c|c|c|c|}
\hline $\begin{array}{c}\text { Peak } \\
\text { No. }\end{array}$ & Name & $\begin{array}{l}\text { Aromatic } \\
\text { Retention } \\
\quad \text { Index }\end{array}$ & $\begin{array}{l}\text { Conc. } \\
\text { (ppm) }\end{array}$ & $\begin{array}{l}\text { Ret. } \\
\text { Time } \\
\text { (min) }\end{array}$ & Area $^{a}$ \\
\hline 1 & BENZENE & 199.9 & 103.3 & 2.46 & 664 \\
\hline 2 & METHYLCYCLOHEXANE & 212.6 & 0.9 & 3.61 & 6 \\
\hline 3 & C2-CYCLOPENTANE & 215.0 & 1.0 & 3.83 & 6 \\
\hline 7 & C2-CYCLOHEXANE & 240.3 & 27.6 & 6.13 & 178 \\
\hline 8 & ISOPROPYLCYCLOPENTANE & 240.7 & 48.3 & 6.16 & 311 \\
\hline 9 & ISOPROPYLCYCLOPENTANE & 241.6 & 156.7 & 6.25 & 1007 \\
\hline 10 & & 243.0 & 97.8 & 6.37 & 629 \\
\hline 11 & ETHYLMETHYCYCLOPENTANE & 244.3 & 22.2 & 6.49 & 143 \\
\hline 12 & ETHYLMETHYCYCLOPENTANE & 245.2 & 5.2 & 6.57 & 33 \\
\hline 13 & & 245.9 & 7.9 & 6.64 & 51 \\
\hline 14 & DIMETHYLCYCLOHEXANE & 247.1 & 44.4 & 6.75 & 285 \\
\hline 15 & ETHYLCYCLOHEXANE & 248.5 & 8.4 & 6.87 & 54 \\
\hline 16 & ETHYLCYCLOHEXANE & 249.3 & 50.4 & 6.95 & 323 \\
\hline 17 & & 250.8 & 194.4 & 7.08 & 1249 \\
\hline 18 & ETHYLBENZENE & 260.8 & 118.8 & 7.99 & 764 \\
\hline 19 & XYLENE & 263.7 & 247.6 & 8.26 & 1591 \\
\hline 20 & & 273.0 & 13.4 & 9.10 & 136 \\
\hline 21 & BENZALDEHYDE & 301.2 & 2.1 & 11.67 & 21 \\
\hline 22 & BIBENZYL & 520.8 & 19.0 & 32.59 & 163 \\
\hline
\end{tabular}

RRI REPORT

SAMPLE: $\quad$ FD650F123HT6

DISK FILE: 22202

GC RUN: $\quad 32584$
TOTAL CONCENTRATION $=1169.5$

NO. OF INTERPRETED PEAKS $=20$

TOTAL NO. OF PEAKS $=22$

TOLUENE DATA:

$$
\begin{array}{ll}
\mathrm{RT}=6.08 & \text { AREA }=6419530 \\
\mathrm{ARI}=240 \% & \mathrm{CONC}=998830
\end{array}
$$

\footnotetext{
area is in a unit that is calibrated when the standard sample
} is analyzed. 
TABLE D.28 Toluene Degradation Report - $650^{\circ} \mathrm{F}, 282 \mathrm{~h}$, Run 312

\begin{tabular}{|c|c|c|c|c|c|}
\hline $\begin{array}{c}\text { Peak } \\
\text { No. }\end{array}$ & Name & $\begin{array}{l}\text { Aromatic } \\
\text { Retention } \\
\quad \text { Index }\end{array}$ & $\begin{array}{l}\text { Conc. } \\
\text { (ppm) }\end{array}$ & $\begin{array}{l}\text { Ret. } \\
\text { Time } \\
\text { (min) }\end{array}$ & Area $^{a}$ \\
\hline 1 & & 101.7 & 1.9 & 1.24 & 8 \\
\hline 2 & BENZENE & 200.0 & 97.7 & 2.43 & 392 \\
\hline 3 & METHYLCYCLOHEXANE & 212.5 & 13.7 & 3.56 & 55 \\
\hline 4 & C2-CYCLOPENTANE & 215.2 & 1.9 & 3.82 & 8 \\
\hline 8 & C8-ALKANE & 237.3 & 33.1 & 5.82 & 133 \\
\hline 9 & C8-ALKANE & 237.7 & 53.0 & 5.86 & 213 \\
\hline 10 & C8-ALKANE & 238.4 & 10.1 & 5.92 & 40 \\
\hline 11 & C2-CYCLOHEXANE & 239.1 & 145.8 & 5.99 & 585 \\
\hline 12 & ISOPROPYLCYCLOPENTANE & 240.6 & 91.3 & 6.13 & 366 \\
\hline 13 & ISOPROPYLCYCLOPENTANE & 242.2 & 22.4 & 6.27 & 90 \\
\hline 14 & & 243.2 & 5.2 & 6.37 & 21 \\
\hline 15 & ETHYLMETHYCYCLOPENTANE & 244.0 & 8.1 & 6.44 & 32 \\
\hline 16 & ETHYLMETHYCYCLOPENTANE & 245.4 & 44.6 & 6.57 & 179 \\
\hline 17 & DIMETHYLCYCLOHEXANE & 246.8 & 8.9 & 6.69 & 35 \\
\hline 18 & & 247.7 & 50.7 & 6.77 & 203 \\
\hline 19 & ETHYLCYCLOHEXANE & 249.3 & 198.3 & 6.92 & 796 \\
\hline 20 & ETHYLBENZENE & 259.6 & 125.1 & 7.86 & 502 \\
\hline 21 & XYLENE & 262.7 & 263.1 & 8.14 & 1056 \\
\hline 22 & & 272.1 & 22.7 & 9.00 & 91 \\
\hline 23 & BENZALDEHYDE & 300.7 & 4.9 & 11.60 & 17 \\
\hline 24 & BIBENZYL & 520.9 & 65.2 & 32.59 & 249 \\
\hline
\end{tabular}

RRI REPORT

$\begin{array}{llr}\text { SAMPLE: } & \text { FD650F290HT6 } & \text { TOTAL CONCENTRATION }=1267.5 \\ \text { DISK FILE: } & 31202 & \text { NO. OF INTERPRETED PEAKS }=22 \\ \text { GC RUN: } & 41584 & \text { TOTAL NO. OF PEAKS }=24\end{array}$

TOLUENE DATA:

$$
\begin{array}{ll}
\mathrm{RT}=5.75 & \text { AREA }=4006900 \\
\mathrm{ARI}=236 \% & \text { CONC }=998733
\end{array}
$$

${ }^{\text {Area }}$ is in a unit that is calibrated when the standard sample is analyzed. 
TABLE D.29 Toluene Degradation Report - $650^{\circ} \mathrm{F}, 282 \mathrm{~h}$, Run 226

\begin{tabular}{|c|c|c|c|c|c|}
\hline $\begin{array}{r}\text { Peak } \\
\text { No. }\end{array}$ & Name & $\begin{array}{l}\text { Aromatic } \\
\text { Retention } \\
\text { Index }\end{array}$ & $\begin{array}{l}\text { Conc. } \\
\text { (ppm) }\end{array}$ & $\begin{array}{l}\text { Ret. } \\
\text { Time } \\
(\min )\end{array}$ & Area ${ }^{a}$ \\
\hline 1 & BENZENE & 200.0 & 99.4 & 2.44 & 552 \\
\hline 2 & METHYLCYCLOHEXANE & 212.5 & 11.7 & 3.58 & 65 \\
\hline 3 & C2-CYCLOPENTANE & 215.0 & 2.8 & 3.80 & 16 \\
\hline 7 & C2-CYCLOHEXANE & 239.1 & 30.6 & 6.00 & 170 \\
\hline 8 & C2-CYCLOHEXANE & 239.4 & 50.9 & 6.03 & 283 \\
\hline 9 & ISOPROPYLCYCLOPENTANE & 240.5 & 155.6 & 6.13 & 864 \\
\hline 10 & ISOPROPYLCYCLOPENTANE & 241.9 & 91.5 & 6.26 & 508 \\
\hline 11 & & 243.4 & 22.4 & 6.39 & 125 \\
\hline 12 & ETHYLMETHYCYCLOPENTANE & 244.3 & 5.0 & 6.47 & 28 \\
\hline 13 & ETHYLMETHYCYCLOPENTANE & 245.0 & 8.1 & 6.54 & 45 \\
\hline 14 & & 246.4 & 44.9 & 6.66 & 249 \\
\hline 15 & & 247.7 & 8.6 & 6.78 & 48 \\
\hline 16 & ETHYLCYCLOHEXANE & 248.5 & 51.1 & 6.86 & 284 \\
\hline 17 & ETHYLCYCLOHEXANE & 250.1 & 198.8 & 7.00 & 1103 \\
\hline 18 & ETHYLBENZENE & 260.2 & 123.2 & 7.91 & 683 \\
\hline 19 & XYLENE & 263.2 & 258.1 & 8.19 & 1432 \\
\hline 20 & & 272.5 & 25.1 & 9.04 & 123 \\
\hline 21 & BENZALDEHYDE & 301.0 & 4.6 & 11.62 & 23 \\
\hline 22 & BIBENZYL & 520.9 & 52.0 & 32.58 & 287 \\
\hline 23 & & 712.5 & 6.4 & 49.75 & 37 \\
\hline
\end{tabular}

RRI REPORT

$\begin{array}{ll}\text { SAMPLE: } & \text { FD600F290HT6 } \\ \text { DISK FILE: } & 22602 \\ \text { GC RUN: } & 4186\end{array}$

TOLUENE DATA:

$$
\begin{array}{ll}
\mathrm{RT}=5.73 & \mathrm{AREA}=5541780 \\
\mathrm{ARI}=236 \% & \mathrm{CONC}=998749
\end{array}
$$

TOTAL CONCENTRATION $=1251$ NO. OF INTERPRETED PEAKS $=21$ TOTAL NO. OF PEAKS $=24$ 
TABLE D.30 Toluene Degradation Report $-650^{\circ} \mathrm{F}, 450 \mathrm{~h}$, Run 240

\begin{tabular}{rlrrrr}
\hline $\begin{array}{r}\text { Peak } \\
\text { No. }\end{array}$ & \multicolumn{1}{c}{ Name } & $\begin{array}{c}\text { Aromatic } \\
\text { Retention } \\
\text { Index }\end{array}$ & $\begin{array}{r}\text { Conc. } \\
\text { (ppm) }\end{array}$ & $\begin{array}{r}\text { Ret. } \\
\text { Time } \\
\text { (min) }\end{array}$ & Area $^{\text {a }}$ \\
\hline & BENZENE & 200.0 & 96.4 & 2.44 & 462 \\
1 & C2-CYCLOPENTANE & 215.0 & 1.0 & 3.81 & 5 \\
2 & C2-CYCLOHEXANE & 238.6 & 30.7 & 5.96 & 147 \\
6 & C2-CYCLOHEXANE & 239.0 & 50.6 & 5.99 & 242 \\
7 & C2-CYCLOHEXANE & 240.2 & 153.6 & 6.10 & 735 \\
9 & ISOPROPYLCYCLOPENTANE & 241.6 & 89.5 & 6.23 & 428 \\
10 & & 243.1 & 22.0 & 6.36 & 105 \\
11 & ETHYLMETHYCYCLOPENTANE & 244.0 & 4.9 & 6.45 & 24 \\
12 & ETHYLMETHYCYCLOPENTANE & 244.8 & 7.9 & 6.52 & 38 \\
13 & & 246.1 & 43.5 & 6.64 & 208 \\
14 & & 247.5 & 8.5 & 6.76 & 41 \\
15 & & 248.3 & 49.8 & 6.84 & 239 \\
16 & ETHYLCYCLOHEXANE & 249.9 & 195.7 & 6.98 & 937 \\
17 & ETHYLBENZENE & 260.0 & 123.1 & 7.90 & 589 \\
18 & XYLENE & 263.1 & 259.2 & 8.18 & 1241 \\
19 & & 272.4 & 26.4 & 9.03 & 107 \\
20 & BENZALDEHYDE & 300.8 & 5.4 & 11.61 & 22 \\
21 & C1-BIPHENYL & 512.2 & 4.0 & 31.72 & 18 \\
22 & BIBENZYL & 520.8 & 85.5 & 32.58 & 386 \\
23 & BIBENZYL & 521.9 & 6.1 & 32.68 & 27 \\
24 & C2-BIPHENYL & 542.7 & 5.2 & 34.74 & 23 \\
25 & C2-BIPHENYL & 546.1 & 4.8 & 35.08 & 22 \\
26 & C1-FLUORENE & 578.8 & 4.9 & 38.31 & 22 \\
& & & & & \\
\hline & & & & & \\
\hline
\end{tabular}

RRI REPORT

$\begin{array}{llr}\text { SAMPLE: } & \text { FD650F457HT6 } & \text { TOTAL CONCENTRATION }=1278.7 \\ \text { DISK FILE: } & 24002 & \text { NO. OF INTERPRETED PEAKS }=24 \\ \text { GC RUN: } & 4884 & \text { TOTAL NO. OF PEAKS }=26\end{array}$

TOLUENE DATA:

$$
\begin{array}{ll}
\mathrm{RT}=5.75 & \text { AREA }=4780850 \\
\mathrm{ARI}=236 \% & \text { CONC }=998721
\end{array}
$$

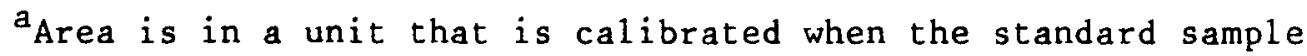
is analyzed. 
TABLE D.31 Toluene Degradation Report - $650^{\circ} \mathrm{F}, 619 \mathrm{~h}$, Run 311

\begin{tabular}{|c|c|c|c|c|c|}
\hline $\begin{array}{c}\text { Peak } \\
\text { No. }\end{array}$ & Name & $\begin{array}{l}\text { Aromatic } \\
\text { Retention } \\
\text { Index }\end{array}$ & $\begin{array}{l}\text { Conc, } \\
\text { (ppm) }\end{array}$ & $\begin{array}{l}\text { Ret. } \\
\text { Time } \\
\text { (min) }\end{array}$ & Area $^{a}$ \\
\hline 1 & BENZENE & 200.0 & 93.5 & 2.45 & 487 \\
\hline 2 & C2-CYCLOPENTANE & 214.9 & 0.5 & 3.81 & 2 \\
\hline 3 & C2-CYCLOPENTANE & 216.5 & 1.3 & 3.95 & 7 \\
\hline 7 & C2-CYCLOHEXANE & 238.7 & 30.7 & 5.97 & 160 \\
\hline 8 & C2-CYCLOHEXANE & 239.0 & 51.3 & 6.00 & 268 \\
\hline 9 & C2-CYCLOHEXANE & 240.2 & 155.0 & 6.10 & 808 \\
\hline 10 & ISOPROPYLCYCLOPENTANE & 241.6 & 89.8 & 6.23 & 469 \\
\hline 11 & & 243.1 & 22.2 & 6.37 & 116 \\
\hline 12 & ETHYLMETHYCYCLOPENTANE & 244.0 & 4.9 & 6.45 & 26 \\
\hline 13 & ETHYLMETHYCYCLOPENTANE & 244.7 & 8.0 & 6.52 & 42 \\
\hline 14 & & 246.1 & 43.7 & 6.64 & 228 \\
\hline 15 & DIMETHYLCYCLOHEXANE & 247.4 & 8.6 & 6.76 & 45 \\
\hline 16 & & 248.3 & 50.2 & 6.84 & 261 \\
\hline 17 & ETHYLCYCLOHEXANE & 249.8 & 196.7 & 6.98 & 1026 \\
\hline 18 & ETHYLBENZENE & 259.9 & 122.1 & 7.90 & 636 \\
\hline 19 & XYLENE & 263.0 & 256.5 & 8.18 & 1337 \\
\hline 20 & & 272.3 & 25.7 & 9.03 & 115 \\
\hline 21 & BENZALDEHYDE & 300.8 & 5.9 & 11.61 & 27 \\
\hline 22 & DIPHENYLMETHANE & 491.5 & 4.5 & 29.68 & 23 \\
\hline 23 & C1-BIPHENYL & 512.1 & 4.4 & 31.72 & 22 \\
\hline 24 & BIBENZYL & 520.9 & 93.9 & 32.59 & 466 \\
\hline 25 & C2-BIPHENYL & 542.7 & 5.9 & 34.75 & 29 \\
\hline 26 & C2-BIPHENYL & 546.0 & 5.7 & 35.08 & 28 \\
\hline 27 & C1-FLUORENE & 578.7 & 12.2 & 38.31 & 61 \\
\hline
\end{tabular}

RRI REPORT

$\begin{array}{llr}\text { SAMPLE: } & \text { FD650F627HT6 } & \text { TOTAL CONCENTRATION }=1293.5 \\ \text { DISK FILE: } & 31102 & \text { NO. OF INTERPRETED PEAKS }=25 \\ \text { GC RUN: } & 41584 & \text { TOTAL NO. OF PEAKS }=27\end{array}$

TOLUENE DATA:

$$
\begin{array}{ll}
\mathrm{RT}=5.88 & \text { AREA }=5205750 \\
\mathrm{ARI}=238 \% & \text { CONC }=998705
\end{array}
$$

${ }^{\text {area }}$ is in a unit that is calibrated when the standard sample is analyzed. 
TABLE D.32 Toluene Degradation Report - 650 ${ }^{\circ}$ F, 786 h, Run 323

\begin{tabular}{|c|c|c|c|c|c|}
\hline $\begin{array}{c}\text { Peak } \\
\text { No. }\end{array}$ & Name & $\begin{array}{l}\text { Aromatic } \\
\text { Retention } \\
\text { Index }\end{array}$ & $\begin{array}{l}\text { Conc. } \\
\text { (ppm) }\end{array}$ & $\begin{array}{l}\text { Ret. } \\
\text { Time } \\
\text { (min) }\end{array}$ & Area $^{a}$ \\
\hline 1 & BENZENE & 200.0 & 89.4 & 2.45 & 489 \\
\hline 2 & METHYLCYCLOHEXANE & 212.4 & 7.1 & 3.57 & 39 \\
\hline 3 & C2-CYCLOPENTANE & 214.8 & 0.7 & 3.79 & 4 \\
\hline 6 & C2-CYCLOHEXANE & 238.6 & 30.8 & 5.95 & 168 \\
\hline 7 & C2-CYCLOHEXANE & 238.9 & 51.3 & 5.99 & 280 \\
\hline 8 & C2-CYCLOHEXANE & 240.1 & 153.9 & 6.09 & 842 \\
\hline 9 & ISOPROPYLCYCLOPENTANE & 241.5 & 88.7 & 6.22 & 486 \\
\hline 10 & & 243.0 & 22.0 & 6.36 & 120 \\
\hline 11 & ETHYLMETHYCYCLOPENTANE & 243.9 & 4.9 & 6.44 & 27 \\
\hline 12 & ETHYLMETHYCYCLOPENTANE & 244.7 & 8.0 & 6.51 & 44 \\
\hline 13 & & 246.1 & 43.1 & 6.63 & 235 \\
\hline 14 & DIMETHYLCYCLOHEXANE & 247.4 & 8.5 & 6.75 & 47 \\
\hline 15 & & 248.2 & 49.7 & 6.83 & 272 \\
\hline 16 & ETHYLCYCLOHEXANE & 249.8 & 195.7 & 6.97 & 1071 \\
\hline 17 & ETHYLBENZENE & 259.9 & 122.4 & 7.89 & 670 \\
\hline 18 & XYLENE & 263.0 & 258.2 & 8.17 & 1413 \\
\hline 19 & & 272.3 & 26.2 & 9.02 & 122 \\
\hline 20 & BENZALDEHYDE & 300.8 & 7.4 & 11.60 & 35 \\
\hline 21 & DIPHENYLMETHANE & 491.5 & 6.3 & 29.67 & 33 \\
\hline 22 & CI-BIPHENYL & 512.2 & 6.0 & 31.71 & 31 \\
\hline 23 & BIBENZYL & 520.9 & 128.5 & 32.57 & 661 \\
\hline 24 & C1-DIPHENYLMETHANE & 523.0 & 4.6 & 32.78 & 24 \\
\hline 25 & C1-DIPHENYLMETHANE & 526.8 & 3.6 & 33.16 & 19 \\
\hline 26 & C2-BIPHENYL & 542.7 & 8.4 & 34.73 & 43 \\
\hline 27 & C2-BIPHENYL & 546.0 & 8.2 & 35.06 & 42 \\
\hline 28 & C3-BIPHENYL & 561.9 & 4.7 & 36.63 & 24 \\
\hline 29 & Cl-FLUORENE & 578.8 & 16.9 & 38.30 & 87 \\
\hline
\end{tabular}

RRI REPORT

$\begin{array}{llr}\text { SAMPLE: } & \text { FD650F794HT6 } & \text { TOTAL CONCENTRATION }=1355.1 \\ \text { DISK FILE: } & 32302 & \text { NO. OF INTERPRETED PEAKS }=28 \\ \text { GC RUN: } & 42386 & \text { TOTAL NO. OF PEAKS }=29\end{array}$

TOLUENE DATA:

$$
\begin{array}{ll}
\text { RT }=5.89 & \text { AREA }=5465480 \\
\text { ARI }=238 \% & \text { CONC }=998645
\end{array}
$$

${ }^{a}$ Area is in a unit that is calibrated when the standard sample is analyzed. 
TABLE D.33 Toluene Degradation Report $-650^{\circ} \mathrm{F}, 955 \mathrm{~h}$, Run 334

\begin{tabular}{|c|c|c|c|c|c|}
\hline $\begin{array}{c}\text { Peak } \\
\text { No. }\end{array}$ & Name & $\begin{array}{c}\text { Aromatic } \\
\text { Retention } \\
\text { Index }\end{array}$ & $\begin{array}{l}\text { Conc. } \\
\text { (ppm) }\end{array}$ & $\begin{array}{l}\text { Ret. } \\
\text { Time } \\
\text { (min) }\end{array}$ & Area $^{8}$ \\
\hline 1 & BENZENE & 200.0 & 104.0 & 2.45 & 473 \\
\hline 2 & METHYLCYCLOHEXANE & 212.4 & 13.2 & 3.57 & 60 \\
\hline 3 & C2-CYCLOPENTANE & 215.0 & 1.8 & 3.81 & 8 \\
\hline 4 & C2-CYCLOPENTANE & 216.3 & 0.7 & 3.93 & 3 \\
\hline 7 & C8-ALKANE & 237.4 & 32.6 & 5.85 & 149 \\
\hline 8 & C8-ALKANE & 237.8 & 52.4 & 5.89 & 239 \\
\hline 9 & C2-CYCLOHEXANE & 238.5 & 9.8 & 5.94 & 45 \\
\hline 10 & C2-CYCLOHEXANE & 239.2 & 143.6 & 6.01 & 654 \\
\hline 11 & ISOPROPYLCYCLOPENTANE & 240.7 & 88.0 & 6.14 & 401 \\
\hline 12 & ISOPROPYLCYCLOPENTANE & 242.2 & 21.7 & 6.29 & 99 \\
\hline 13 & & 243.3 & 5.0 & 6.38 & 23 \\
\hline 14 & ETHYLMETHYCYCLOPENTANE & 244.0 & 7.8 & 6.45 & 36 \\
\hline 15 & ETHYLMETHYCYCLOPENTANE & 245.4 & 42.4 & 6.57 & 193 \\
\hline 16 & DIMETHYLCYCLOHEXANE & 246.8 & 8.7 & 6.70 & 39 \\
\hline 17 & & 247.7 & 49.1 & 6.78 & 224 \\
\hline 18 & ETHYLCYCLOHEXANE & 249.2 & 194.3 & 6.92 & 885 \\
\hline 19 & ETHYLBENZENE & 259.5 & 119.2 & 7.86 & 543 \\
\hline 20 & XYLENE & 262.6 & 253.5 & 8.14 & 1155 \\
\hline 21 & & 272.0 & 21.5 & 8.99 & 98 \\
\hline 22 & BENZALDEHYDE & 300.6 & 8.3 & 11.59 & 31 \\
\hline 23 & DIPHENYLMETHANE & 491.5 & 7.7 & 29.67 & 32 \\
\hline 24 & C1-BIPHENYL & 512.1 & 7.6 & 31.71 & 31 \\
\hline 25 & BIBENZYL & 520.9 & 153.2 & 32.57 & 635 \\
\hline 26 & C1-DIPHENYLMETHANE & 523.1 & 5.6 & 32.79 & 24 \\
\hline 27 & C1-DI PHENYLMETHANE & 526.8 & 4.5 & 33.16 & 19 \\
\hline 28 & C2-BIPHENYL & 542.8 & 10.0 & 34.74 & 42 \\
\hline 29 & C2-BIPHENYL & 546.1 & 9.6 & 35.06 & 40 \\
\hline 30 & C3-BIPHENYL & 561.9 & 5.5 & 36.63 & 23 \\
\hline 31 & C1-FLUORENE & 578.8 & 19.9 & 38.30 & 83 \\
\hline
\end{tabular}

RRI REPORT

SAMPLE: $\quad$ FD650962HT6

DISK FILE: 33402

GC RUN: $\quad 42986$
TOTAL CONCENTRATION $=1401.5$

NO. OF INTERPRETED PEAKS $=30$ TOTAL NO. OF PEAKS $=31$

TOLUENE DATA:

$$
\begin{array}{ll}
\text { RT }=5.77 & \text { AREA }=4548180 \\
\text { ARI }=237 \% & \text { CONC }=998598
\end{array}
$$

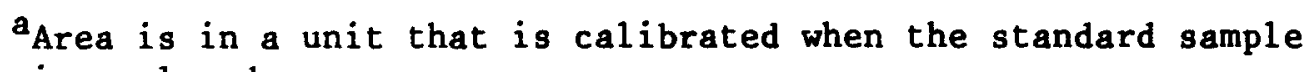
is analyzed. 
TABLE D.34 Toluene Degradation Report $-650^{\circ} \mathrm{F}, 1006 \mathrm{~h}$, Run 378

\begin{tabular}{|c|c|c|c|c|c|}
\hline $\begin{array}{c}\text { Peak } \\
\text { No. }\end{array}$ & Name & $\begin{array}{c}\text { Aromatic } \\
\text { Retention } \\
\text { Index }\end{array}$ & $\begin{array}{l}\text { Conc. } \\
\text { (ppm) }\end{array}$ & $\begin{array}{l}\text { Ret. } \\
\text { Time } \\
\text { (min) }\end{array}$ & Area ${ }^{a}$ \\
\hline 1 & & 85.3 & 12.8 & 1.02 & 69 \\
\hline 2 & BENZENE & 200.0 & 91.5 & 2.39 & 494 \\
\hline 3 & METHYLCYCLOHEXANE & 212.5 & 15.7 & 3.52 & 85 \\
\hline 4 & C2-CYCLOPENTANE & 214.7 & 6.9 & 3.72 & 37 \\
\hline 6 & ISOPROPYLCYCLOPENTANE & 240.8 & 120.1 & 6.08 & 648 \\
\hline 7 & ISOPROPYLCYCLOPENTANE & 242.1 & 79.6 & 6.20 & 430 \\
\hline 8 & ETHYLMETHYCYCLOPENTANE & 243.5 & 17.9 & 6.32 & 96 \\
\hline 9 & ETHYLMETHYCYCLOPENTANE & 245.1 & 9.9 & 6.47 & 53 \\
\hline 10 & & 246.4 & 41.2 & 6.58 & 223 \\
\hline 11 & ETHYLCYCLOHEXANE & 248.5 & 56.3 & 6.78 & 304 \\
\hline 12 & ETHYLCYCLOHEXANE & 250.0 & 190.9 & 6.91 & 1031 \\
\hline 13 & ETHYLBENZENE & 260.0 & 121.2 & 7.81 & 654 \\
\hline 14 & XYLENE & 263.0 & 257.2 & 8.09 & 1388 \\
\hline 15 & & 272.2 & 22.6 & 8.92 & 122 \\
\hline 16 & BENZALDEHYDE & 300.6 & 12.0 & 11.48 & 55 \\
\hline 17 & DIPHENYLMETHANE & 491.5 & 7.5 & 29.50 & 37 \\
\hline 18 & C1-BIPHENYL & 512.1 & 7.7 & 31.55 & 35 \\
\hline 19 & BIBENZYL & 520.9 & 165.5 & 32.41 & 758 \\
\hline 20 & C1-DI PHENYLMETHANE & 526.7 & 5.0 & 32.99 & 23 \\
\hline 21 & C2-BIPHENYL & 542.7 & 10.2 & 34.57 & 47 \\
\hline 22 & C2-BIPHENYL & 546.0 & 9.8 & 34.90 & 45 \\
\hline 23 & C3-BI PHENYL & 561.9 & 5.4 & 36.46 & 25 \\
\hline 24 & C1-FLUORENE & 578.8 & 4.9 & 38.14 & 23 \\
\hline
\end{tabular}

RRI REPORT

$\begin{array}{llr}\text { SAMPLE: } & \text { FD650F1013HT6 } & \text { TOTAL CONCENTRATION }=1272 \\ \text { DISK FILE: } & 37801 & \text { NO. OF INTERPRETED PEAKS }=24 \\ \text { GC RUN: } & 12386 & \text { TOTAL NO. OF PEAKS }=24\end{array}$

TOLUENE DATA:

$$
\begin{array}{ll}
\mathrm{RT}=5.89 & \text { AREA }=5391270 \\
\mathrm{ARI}=239 \% & \text { CONC }=998728
\end{array}
$$

${ }^{a}$ Area is in a unit that is calibrated when the standard sample is analyzed. 
TABLE D.35 Toluene Degradation Report $-677^{\circ} \mathrm{F}, 0 \mathrm{~h}$, Run 351

\begin{tabular}{|c|c|c|c|c|c|}
\hline $\begin{array}{c}\text { Peak } \\
\text { No. }\end{array}$ & Name & $\begin{array}{l}\text { Aromatic } \\
\text { Retention } \\
\text { Index }\end{array}$ & $\begin{array}{l}\text { Conc. } \\
\text { (ppm) }\end{array}$ & $\begin{array}{l}\text { Ret. } \\
\text { Time } \\
\text { (min) }\end{array}$ & Area ${ }^{a}$ \\
\hline 1 & BENZENE & 200.0 & 83.9 & 2.40 & 426 \\
\hline 2 & & 201.5 & 85.2 & 2.53 & 433 \\
\hline 3 & $\mathrm{C} 6 \mathrm{H} 14$ & 205.3 & 15.6 & 2.88 & 79 \\
\hline 4 & C6H14 & 206.4 & 11.9 & 2.98 & 60 \\
\hline 7 & C2-CYCLOHEXANE & 238.7 & 15.4 & 5.87 & 78 \\
\hline 8 & C2-CYCLOHEXANE & 239.0 & 20.9 & 5.90 & 106 \\
\hline 9 & C2-CYCLOHEXANE & 240.2 & 128.5 & 6.00 & 653 \\
\hline 10 & ISOPROPYLCYCLOPENTANE & 241.7 & 185.2 & 6.14 & 941 \\
\hline 11 & & 243.1 & 28.2 & 6.27 & 143 \\
\hline 12 & ETHYLMETHYCYCLOPENTANE & 244.1 & 4.1 & 6.35 & 21 \\
\hline 13 & ETHYLMETHYCYCLOPENTANE & 244.8 & 26.0 & 6.42 & 132 \\
\hline 14 & & 246.2 & 72.6 & 6.54 & 369 \\
\hline 15 & & 247.5 & 22.9 & 6.66 & 116 \\
\hline 16 & & 248.4 & 89.4 & 6.74 & 454 \\
\hline 17 & ETHYLCYCLOHEXANE & 250.0 & 472.1 & 6.89 & 2399 \\
\hline 18 & ETHYLBENZENE & 260.1 & 101.1 & 7.79 & 514 \\
\hline 19 & XYLENE & 263.2 & 89.5 & 8.07 & 455 \\
\hline
\end{tabular}

RRI REPORT

$\begin{array}{llr}\text { SAMPLE: } & \text { FD677FOHT7 } & \text { TOTAL CONCENTRATION }=1452.5 \\ \text { DISK FILE: } & 35102 & \text { NO. OF INTERPRETED PEAKS }=18 \\ \text { GC RUN: } & 61286 & \text { TOTAL NO. OF PEAKS }=19\end{array}$

TOLUENE DATA:

$$
\begin{array}{ll}
\text { RT }=5.81 & \text { AREA }=5073450 \\
\text { ARI }=238 \% & \text { CONC }=998547
\end{array}
$$

${ }^{\text {Area }}$ is in anit that is calibrated when the standard sample is analyzed. 
TABLE D.36 Toluene Degradation Report $-677^{\circ} \mathrm{F}, 117$ h, Run 352

\begin{tabular}{|c|c|c|c|c|c|}
\hline $\begin{array}{c}\text { Peak } \\
\text { No. }\end{array}$ & Name & $\begin{array}{c}\text { Aromatic } \\
\text { Retention } \\
\text { Index }\end{array}$ & $\begin{array}{l}\text { Conc. } \\
\text { (ppm) }\end{array}$ & $\begin{array}{l}\text { Ret. } \\
\text { Time } \\
\text { (min) }\end{array}$ & Area $^{a}$ \\
\hline 1 & & 99.7 & 2.5 & 1.21 & 17 \\
\hline 2 & & 108.7 & 5.1 & 1.32 & 35 \\
\hline 3 & BENZENE & 200.0 & 82.0 & 2.43 & 551 \\
\hline 4 & $\mathrm{C} 6 \mathrm{H} 14$ & 203.3 & 0.6 & 2.73 & 4 \\
\hline 5 & & 206.7 & 37.6 & 3.03 & 252 \\
\hline 6 & METHYLCYCLOHEXANE & 212.1 & 16.2 & 3.52 & 109 \\
\hline 13 & C2-CYCLOHEXANE & 240.2 & 12.9 & 6.05 & 87 \\
\hline 14 & C2-CYCLOHEXANE & 240.4 & 21.6 & 6.07 & 145 \\
\hline 15 & ISOPROPYLCYCLOPENTANE & 241.4 & 126.3 & 6.16 & 849 \\
\hline 16 & & 242.7 & 183.1 & 6.28 & 1231 \\
\hline 17 & ETHYLMETHYCYCLOPENTANE & 244.0 & 27.9 & 6.39 & 188 \\
\hline 18 & ETHYLMETHYCYCLOPENTANE & 244.8 & 3.9 & 6.47 & 26 \\
\hline 19 & & 245.5 & 25.6 & 6.53 & 172 \\
\hline 20 & DIMETHYLCYCLOHEXANE & 246.8 & 71.2 & 6.65 & 478 \\
\hline 21 & & 248.1 & 22.6 & 6.76 & 152 \\
\hline 22 & & 248.9 & 88.6 & 6.84 & 595 \\
\hline 23 & ETHYLCYCLOHEXANE & 250.5 & 472.6 & 6.98 & 3176 \\
\hline 24 & & 256.5 & 2.1 & 7.52 & 14 \\
\hline 25 & & 258.2 & 3.1 & 7.67 & 21 \\
\hline 26 & ETHYLBENZENE & 260.2 & 106.8 & 7.85 & 718 \\
\hline 27 & XYLENE & 263.2 & 92.0 & 8.12 & 618 \\
\hline 28 & & 272.4 & 3.0 & 8.95 & 21 \\
\hline 29 & BENZALDEHYDE & 300.7 & 2.1 & 11.50 & 14 \\
\hline 30 & BIBENZYL & 520.9 & 37.1 & 32.35 & 273 \\
\hline 31 & C2-BIPHENYL & 542.8 & 2.4 & 34.51 & 18 \\
\hline
\end{tabular}

RRI REPORT

SAMPLE:

FD677F117HT7

TOTAL CONCENTRATION $=1449$

DISK FILE: 35202

GC RUN: 61286

NO. OF INTERPRETED PEAKS $=26$

TOTAL NO. OF PEAKS $=31$

TOLUENE DATA:

$$
\begin{array}{ll}
\mathrm{RT}=6.00 & \text { AREA }=6711240 \\
\mathrm{ARI}=240 \% & \text { CONC }=998550
\end{array}
$$

${ }^{a}$ Area is in a unit that is calibrated when the standard sample is analyzed. 
TABLE D.37 Toluene Degradation Report - $677^{\circ} \mathrm{F}, 285 \mathrm{~h}$, Run 353

\begin{tabular}{|c|c|c|c|c|c|}
\hline $\begin{array}{c}\text { Peak } \\
\text { No. }\end{array}$ & Name & $\begin{array}{l}\text { Aromatic } \\
\text { Retention } \\
\quad \text { Index }\end{array}$ & $\begin{array}{l}\text { Conc, } \\
\text { (ppm) }\end{array}$ & $\begin{array}{l}\text { Ret. } \\
\text { Time } \\
\text { (min) }\end{array}$ & Area ${ }^{a}$ \\
\hline 1 & & 110.8 & 3.4 & 1.34 & 25 \\
\hline 2 & & 135.5 & 3.6 & 1.63 & 27 \\
\hline 3 & BENZENE & 200.0 & 82.5 & 2.41 & 618 \\
\hline 4 & & 206.6 & 18.7 & 3.01 & 139 \\
\hline 5 & METHYLCYCLOHEXANE & 212.3 & 21.5 & 3.52 & 161 \\
\hline 14 & ISOPROPYLCYCLOPENTANE & 241.1 & 14.2 & 6.12 & 106 \\
\hline 15 & ISOPROPYLCYCLOPENTANE & 241.4 & 20.4 & 6.14 & 153 \\
\hline 16 & ISOPROPYLCYCLOPENTANE & 242.2 & 125.1 & 6.22 & 936 \\
\hline 17 & & 243.4 & 180.7 & 6.33 & 1353 \\
\hline 18 & ETHYLMETHYCYCLOPENTANE & 244.7 & 27.8 & 6.44 & 208 \\
\hline 19 & & 245.5 & 3.5 & 6.51 & 26 \\
\hline 20 & & 246.2 & 25.3 & 6.58 & 189 \\
\hline 21 & DIMETHYLCYCLOHEXANE & 247.4 & 69.6 & 6.69 & 521 \\
\hline 22 & & 248.7 & 22.3 & 6.80 & 167 \\
\hline 23 & & 249.5 & 87.1 & 6.87 & 652 \\
\hline 24 & ETHYLCYCLOHEXANE & 251.0 & 469.6 & 7.01 & 3517 \\
\hline 25 & & 256.9 & 1.9 & 7.54 & 15 \\
\hline 26 & ETHYLBENZENE & 258.6 & 3.0 & 7.70 & 22 \\
\hline 27 & ETHYLBENZENE & 260.6 & 103.4 & 7.88 & 774 \\
\hline 28 & XYLENE & 261.8 & 2.9 & 7.98 & 22 \\
\hline 29 & XYLENE & 263.6 & 91.5 & 8.14 & 685 \\
\hline 30 & & 272.7 & 3.3 & 8.97 & 25 \\
\hline 31 & BENZALDEHYDE & 300.8 & 2.6 & 11.50 & 19 \\
\hline 32 & DIPHENYLMETHANE & 491.4 & 3.0 & 29.46 & 25 \\
\hline 33 & BIBENZYL & 520.9 & 60.6 & 32.36 & 496 \\
\hline 34 & C2-BIPHENYL & 542.8 & 4.4 & 34.52 & 35 \\
\hline 35 & C2-BIPHENYL & 546.1 & 4.2 & 34.84 & 34 \\
\hline 36 & C1-ELUORENE & 578.8 & 3.8 & 38.07 & 31 \\
\hline
\end{tabular}

RRI REPORT

$\begin{array}{llr}\text { SAMPLE: } & \text { FD677F283HT7 } & \text { TOTAL CONCENTRATION }=1459.7 \\ \text { DISK FILE: } & 35302 & \text { NO. OF INTERPRETED PEAKS }=29 \\ \text { GC RUN: } & 61286 & \text { TOTAL NO. OF PEAKS }=36\end{array}$

TOLUENE DATA:

$$
\begin{array}{ll}
\text { RT }=6.08 & \text { AREA }=7476760 \\
\text { ARI }=241 \% & \text { CONC }=998540
\end{array}
$$

area is in a unit that is calibrated when the standard sample is analyzed. 
TABLE D.38 Toluene Degradation Report $-677^{\circ} \mathrm{F}, 600 \mathrm{~h}$, Run 363

\begin{tabular}{|c|c|c|c|c|c|}
\hline $\begin{array}{c}\text { Peak } \\
\text { No. }\end{array}$ & Name & $\begin{array}{l}\text { Aromatic } \\
\text { Retention } \\
\text { Index }\end{array}$ & $\begin{array}{l}\text { Conc. } \\
\text { (ppm) }\end{array}$ & $\begin{array}{l}\text { Ret. } \\
\text { Time } \\
\text { (min) }\end{array}$ & Area $^{a}$ \\
\hline 1 & BENZENE & 200.0 & 75.9 & 2.43 & 416 \\
\hline 5 & C2-CYCLOHEXANE & 239.7 & 14.8 & 6.01 & 81 \\
\hline 6 & C2-CYCLOHEXANE & 240.1 & 23.0 & 6.04 & 126 \\
\hline 7 & ISOPROPYLCYCLOPENTANE & 241.1 & 127.2 & 6.13 & 697 \\
\hline 8 & ISOPROPYLCYCLOPENTANE & 242.4 & 176.5 & 6.26 & 968 \\
\hline 9 & ETHYLMETHYCYCLOPENTANE & 243.8 & 27.5 & 6.38 & 151 \\
\hline 10 & ETHYLMETHYCYCLOPENTANE & 244.7 & 3.6 & 6.46 & 20 \\
\hline 11 & ETHYLMETHYCYCLOPENTANE & 245.4 & 25.4 & 6.52 & 139 \\
\hline 12 & DIMETHYLCYCLOHEXANE & 246.7 & 67.4 & 6.64 & 369 \\
\hline 13 & & 248.0 & 22.3 & 6.76 & 122 \\
\hline 14 & & 248.9 & 86.0 & 6.84 & 471 \\
\hline 15 & ETHYLCYCLOHEXANE & 250.5 & 472.2 & 6.98 & 2589 \\
\hline 16 & ETHYLBENZENE & 260.3 & 103.3 & 7.87 & 567 \\
\hline 17 & XYLENE & 263.3 & 90.3 & 8.14 & 495 \\
\hline 18 & & 272.5 & 3.5 & 8.97 & 19 \\
\hline 19 & BENZALDEHYDE & 300.8 & 4.1 & 11.52 & 20 \\
\hline 20 & DI PHENYLMETHANE & 491.5 & 6.5 & 29.48 & 36 \\
\hline 21 & C1-BIPHENYL & 512.2 & 6.9 & 31.52 & 38 \\
\hline 22 & BIBENZYL & 521.0 & 120.7 & 32.39 & 673 \\
\hline 23 & C2-BI PHENYL & 542.8 & 9.4 & 34.54 & 52 \\
\hline 24 & C2-BI PHENYL & 546.1 & 9.0 & 34.86 & 50 \\
\hline 25 & C1-FLUORENE & 578.8 & 4.7 & 38.09 & 26 \\
\hline
\end{tabular}

RRI REPORT

$\begin{array}{llr}\text { SAMPLE: } & \text { FD677F599HT7 } & \text { TOTAL CONCENTRATION }=1480 \\ \text { DISK FILE: } & 36302 & \text { NO. OF INTERPRETED PEAKS }=23 \\ \text { GC RUN: } & 7886 & \text { TOTAL NO. OF PEAKS }=25\end{array}$

TOLUENE DATA:

$$
\begin{array}{ll}
\mathrm{RT}=5.62 & \text { AREA }=5474350 \\
\mathrm{ARI}=235 \% & \text { CONC }=998520
\end{array}
$$

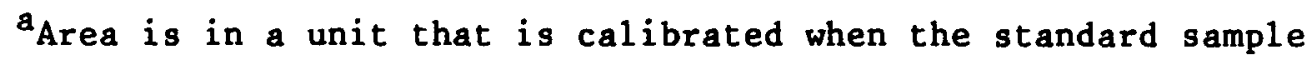
is analyzed. 
TABLE D.39 Toluene Degradation Report - $677^{\circ} \mathrm{F}, 789$ h, Run 362

\begin{tabular}{|c|c|c|c|c|c|}
\hline $\begin{array}{c}\text { Peak } \\
\text { No. }\end{array}$ & Name & $\begin{array}{l}\text { Aromatic } \\
\text { Retention } \\
\text { Index }\end{array}$ & $\begin{array}{l}\text { Conc. } \\
\text { (ppm) }\end{array}$ & $\begin{array}{l}\text { Ret. } \\
\text { Time } \\
\text { (min) }\end{array}$ & Area $^{a}$ \\
\hline 1 & BENZENE & 200.0 & 73.8 & 2.43 & 313 \\
\hline 2 & & 206.9 & 40.2 & 3.05 & 170 \\
\hline 3 & METHYLCYCLOHEXANE & 212.7 & 62.1 & 3.57 & 263 \\
\hline 7 & C8-ALKANE & 237.9 & 16.0 & 5.85 & 68 \\
\hline 8 & C8-ALKANE & 238.3 & 23.8 & 5.88 & 101 \\
\hline 9 & C2-CYCLOHEXANE & 239.5 & 128.8 & 5.99 & 546 \\
\hline 10 & ISOPROPYLCYCLOPENTANE & 241.1 & 174.7 & 6.13 & 741 \\
\hline 11 & & 242.6 & 27.5 & 6.27 & 117 \\
\hline 12 & ETHYLMETHYCYCLOPENTANE & 243.6 & 3.5 & 6.36 & 15 \\
\hline 13 & ETHYLMETHYCYCLOPENTANE & 244.3 & 25.5 & 6.42 & 108 \\
\hline 14 & & 245.7 & 65.9 & 6.55 & 280 \\
\hline 15 & DIMETHYLCYCLOHEXANE & 247.0 & 21.7 & 6.67 & 92 \\
\hline 16 & & 247.9 & 84.3 & 6.75 & 358 \\
\hline 17 & ETHYLCYCLOHEXANE & 249.6 & 468.0 & 6.90 & 1985 \\
\hline 18 & ETHYLBENZENE & 259.7 & 103.6 & 7.81 & 440 \\
\hline 19 & XYLENE & 262.7 & 90.7 & 8.08 & 385 \\
\hline 20 & BENZALDEHYDE & 300.6 & 4.6 & 11.49 & 17 \\
\hline 21 & DIPHENYLMETHANE & 491.5 & 9.1 & 29.48 & 38 \\
\hline 22 & C1-BIPHENYL & 512.2 & 9.9 & 31.52 & 43 \\
\hline 23 & Cl-DIPHENYLMETHANE & 516.6 & 4.3 & 31.95 & 19 \\
\hline 24 & BIBENZYL & 521.0 & 163.2 & 32.38 & 704 \\
\hline 25 & Cl-DIPHENYLMETHANE & 523.1 & 5.4 & 32.59 & 23 \\
\hline 26 & C2-BIPHENYL & 542.8 & 14.0 & 34.53 & 60 \\
\hline 27 & C2-BIPHENYL & 546.1 & 13.3 & 34.86 & 58 \\
\hline 28 & C3-BIPHENYL & 561.9 & 5.4 & 36.42 & 23 \\
\hline 29 & C1-FLUORENE & 578.8 & 8.5 & 38.08 & 36 \\
\hline
\end{tabular}

RRI REPORT

$\begin{array}{llr}\text { SAMPLE: } & \text { FD677F787HT7 } & \text { TOTAL CONCENTRATION }=1647.5 \\ \text { DISK FILE: } & 36202 & \text { NO. OF INTERPRETED PEAKS }=27 \\ \text { GC RUN: } & 7886 & \text { TOTAL NO. OF PEAKS }=29\end{array}$

TOLUENE DATA:

$$
\begin{array}{ll}
\mathrm{RT}=5.78 & \text { AREA }=4235120 \\
\mathrm{ARI}=237 \% & \text { CONC }=998352
\end{array}
$$

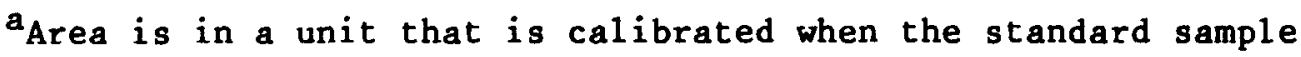
is analyzed. 
TABLE D.40 Toluene Degradation Report $-677^{\circ} \mathrm{F}, 958 \mathrm{~h}$, Run 364

\begin{tabular}{|c|c|c|c|c|c|}
\hline $\begin{array}{c}\text { Peak } \\
\text { No. }\end{array}$ & Name & $\begin{array}{l}\text { Aromatic } \\
\text { Retention } \\
\text { Index }\end{array}$ & $\begin{array}{l}\text { Conc, } \\
\text { (ppm) }\end{array}$ & $\begin{array}{l}\text { Ret. } \\
\text { Time } \\
\text { (min) }\end{array}$ & Area $^{a}$ \\
\hline 1 & BENZENE & 200.0 & 76.9 & 2.39 & 305 \\
\hline 2 & & 206.8 & 39.6 & 3.01 & 157 \\
\hline 3 & METHYLCYCLOHEXANE & 212.4 & 46.9 & 3.51 & 186 \\
\hline 7 & C8-ALKANE & 237.4 & 16.4 & 5.77 & 65 \\
\hline 8 & C8-ALKANE & 237.9 & 24.4 & 5.81 & 97 \\
\hline 9 & C2-CYCLOHEXANE & 239.1 & 129.1 & 5.92 & 513 \\
\hline 10 & ISOPROPYLCYCLOPENTANE & 240.7 & 173.3 & 6.07 & 688 \\
\hline 11 & ISOPROPYLCYCLOPENTANE & 242.3 & 27.4 & 6.21 & 109 \\
\hline 12 & & 243.3 & 3.5 & 6.30 & 14 \\
\hline 13 & ETHYLMETHYCYCLOPENTANE & 244.0 & 25.5 & 6.36 & 101 \\
\hline 14 & ETHYLMETHYCYCLOPENTANE & 245.4 & 64.9 & 6.49 & 258 \\
\hline 15 & DIMETHYLCYCLOHEXANE & 246.7 & 21.6 & 6.61 & 86 \\
\hline 16 & & 247.6 & 83.5 & 6.69 & 331 \\
\hline 17 & ETHYLCYCLOHEXANE & 249.3 & 466.1 & 6.84 & 1850 \\
\hline 18 & ETHYLBENZENE & 259.5 & 102.9 & 7.76 & 409 \\
\hline 19 & XYLENE & 262.5 & 90.8 & 8.04 & 361 \\
\hline 20 & BENZALDEHYDE & 300.5 & 5.1 & 11.46 & 18 \\
\hline 21 & DIPHENYLMETHANE & 491.6 & 12.0 & 29.47 & 48 \\
\hline 22 & C1-BIPHENYL & 512.3 & 12.9 & 31.51 & 52 \\
\hline 23 & C1-DIPHENYLMETHANE & 516.6 & 5.5 & 31.94 & 22 \\
\hline 24 & BIBENZYL & 521.0 & 202.8 & 32.38 & 818 \\
\hline 25 & Cl-DIPHENYLMETHANE & 523.1 & 7.0 & 32.58 & 28 \\
\hline 26 & C1-DIPHENYLMETHANE & 526.9 & 5.4 & 32.95 & 22 \\
\hline 27 & C2-BIPHENYL & 542.8 & 17.8 & 34.53 & 72 \\
\hline 28 & C2-BIPHENYL & 546.1 & 17.0 & 34.85 & 68 \\
\hline 29 & C3-BIPHENYL & 562.0 & 6.8 & 36.42 & 27 \\
\hline 30 & C1-FLUORENE & 578.8 & 10.6 & 38.08 & 43 \\
\hline
\end{tabular}

RRI REPORT

$\begin{array}{llr}\text { SAMPLE: } & \text { FD677F956HT7 } & \text { TOTAL CONCENTRATION }=1696 \\ \text { DISK FILE: } & 36402 & \text { NO. OF INTERPRETED PEAKS }=28 \\ \text { GC RUN: } & 7886 & \text { TOTAL NO. OF PEAKS }=30\end{array}$

TOLUENE DATA:

$$
\begin{array}{ll}
\text { RT }=5.70 & \text { AREA }=3963260 \\
\text { ARI }=237 \% & \text { CONC }=998304
\end{array}
$$

${ }^{a}$ Area is in a unit that is calibrated when the standard sample is analyzed. 


$$
183 / / 84
$$

TABLE D.41 Toluene Degradation Report - $677^{\circ} \mathrm{F}, 1006 \mathrm{~h}$, Run 376

\begin{tabular}{rlrrrr}
\hline $\begin{array}{r}\text { Peak } \\
\text { No. }\end{array}$ & Name & $\begin{array}{c}\text { Aromatic } \\
\text { Retention } \\
\text { Index }\end{array}$ & $\begin{array}{r}\text { Conc. } \\
\text { (ppm) }\end{array}$ & $\begin{array}{l}\text { Ret. } \\
\text { Time } \\
(\mathrm{min})\end{array}$ & Area $^{\text {a }}$ \\
\hline & & & & & \\
1 & BENZENE & 200.0 & 72.4 & 2.36 & 320 \\
2 & & 206.8 & 37.5 & 2.97 & 166 \\
3 & METHYLCYCLOHEXANE & 212.6 & 60.1 & 3.50 & 266 \\
6 & C2-CYCLOHEXANE & 239.8 & 108.9 & 5.97 & 482 \\
7 & ISOPROPYLCYCLOPENTANE & 241.3 & 166.1 & 6.10 & 735 \\
8 & & 242.8 & 24.5 & 6.24 & 108 \\
9 & ETHYLMETHYCYCLOPENTANE & 244.5 & 26.9 & 6.39 & 119 \\
10 & & 245.9 & 65.5 & 6.51 & 290 \\
11 & & 248.1 & 107.3 & 6.71 & 475 \\
12 & ETHYLCYCLOHEXANE & 249.7 & 468.2 & 6.86 & 2072 \\
13 & ETHYLBENZENE & 259.8 & 105.9 & 7.77 & 469 \\
14 & XYLENE & 262.8 & 93.5 & 8.04 & 413 \\
15 & & 272.2 & 4.3 & 8.89 & 19 \\
16 & BENZALDEHYDE & 300.7 & 10.6 & 11.47 & 40 \\
17 & DIPHENYLMETHANE & 491.5 & 9.6 & 29.51 & 39 \\
18 & C1-BIPHENYL & 512.2 & 11.6 & 31.55 & 43 \\
19 & BIBENZYL & 520.9 & 178.8 & 32.41 & 670 \\
20 & C1-DIPHENYLMETHANE & 523.0 & 6.2 & 32.62 & 23 \\
21 & C2-BIPHENYL & 542.8 & 15.0 & 34.57 & 56 \\
22 & C2-BIPHENYL & 546.1 & 14.2 & 34.90 & 53 \\
& & & & & \\
\hline & & & & & \\
\hline
\end{tabular}

RRI REPORT

$\begin{array}{llr}\text { SAMPLE: } & \text { FD677F1005HT7 } & \text { TOTAL CONCENTRATION }=1587 \\ \text { DISK FILE: } & 37601 & \text { NO. OF INTERPRETED PEAKS }=21 \\ \text { GC RUN: } & 12386 & \text { TOTAL NO. OF PEAKS }=22\end{array}$

TOLUENE DATA:

$$
\begin{array}{ll}
\mathrm{RT}=5.76 & \text { AREA }=4418300 \\
\mathrm{ARI}=238 \% & \text { CONC }=998413
\end{array}
$$

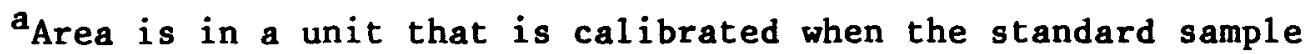
is analyzed. 
$185 / / 86$

APPENDIX E:

COMPUTER PROGRAM AND PREDICTED DEGRADATION 



\section{APPENDIX E:}

\section{COMPUTER PROGRAM AND PREDICTED DEGRADATION}

The computer program that follows runs on an Apple IIt computer. The constants $R_{0}$ and $K$ in line 50010 were determined empirically.* The ONERR GOTO 1000 instruction in line 40 causes control to be transferred to line 1000 when the end of the input file (or any other error) is detected. The POKE 216,0 instruction in line 1000 re-establishes normal error-detection procedures. An input data file consists of the following lines:

Line 1: $\quad$ Informational header

Line 2: $\quad$ Duration of operation (h), cross-sectional area of the fluid passageways (in. ${ }^{2}$ ), fluid inventory (lb)

Lines 3...n: Distance from datum (in.), fluid temperature $\left({ }^{\circ} R\right)$, fluid density $\left(\mathrm{lb}_{\mathrm{m}} / \mathrm{in}^{3}\right)$

10

20

30

35

40

50

60

70

80

100

110

150

1000

39999

40000

49999

50000

50010

GOSUB 50000: PRINT D\$;"PR非": PRINT D\$;"OPEN";FI\$： PRINT D\$;"READ";FI\$ INPUT HS: PRINT H\$: PRINT INPUT TE, A,M:C4 = TE * RO * A / M: PRINT "DURATION = ";TE: PRINT "CROSS-SECTIONAL AREA = "; A: PRINT "FLUID WEIGHT = ";M: PRINT PRINT " $X$ TEMP DENSITY INTEGRAL"

INPUT $\mathrm{X} 1, \mathrm{~T} 1, \mathrm{D} 1: \mathrm{Z}=\mathrm{X} 1: \operatorname{GOSUB} 40000: \mathrm{Z}=\mathrm{T} 1: \operatorname{COSUB} 40000: \mathrm{Z}=\mathrm{D} 1:$ GOSUB 40000: PRINT : ONERR GOTO 1000

INPUT $\mathrm{X} 2, \mathrm{~T} 2, \mathrm{D} 2: \mathrm{Z}=\mathrm{X} 2: \operatorname{GOSUB} 40000: \mathrm{Z}=\mathrm{T} 2: \operatorname{GOSUB} 40000: \mathrm{Z}=\mathrm{D} 2:$ GOSUB 40000

$$
\text { IF } \mathrm{T} 1><\mathrm{T} 2 \text { THEN } 100
$$

$$
\mathrm{DI}=\mathrm{C} 4 * \operatorname{EXP}(-\mathrm{K} / \mathrm{T} 2) *(\mathrm{D} 1+\mathrm{D} 2) *(\mathrm{X} 2-\mathrm{X} 1) / 2: \operatorname{PRINT} " \text { "; DI }
$$
GOTO 150

$\mathrm{C} 1=\mathrm{K} *(\mathrm{D} 1-((\mathrm{D} 2-\mathrm{D} 1) /(\mathrm{T} 2-\mathrm{T} 1)) * \mathrm{~T} 1): \mathrm{C} 2=\mathrm{K} * \mathrm{~K} *(\mathrm{D} 2-\mathrm{D} 1) /$ $(\mathrm{T} 2-\mathrm{T} 1) / 2: \mathrm{C} 3=\mathrm{C} 4 *(\mathrm{X} 2-\mathrm{X} 1) /(\mathrm{T} 2-\mathrm{T} 1)$

$$
\begin{aligned}
& \mathrm{DI}=\mathrm{C} 3 *(\mathrm{FN} \mathrm{F}(\mathrm{K} / \mathrm{T} 2)-\mathrm{FN} \mathrm{F}(\mathrm{K} / \mathrm{T} 1)): \text { PRINT " ";DI } \\
& \mathrm{II}=\mathrm{II}+\mathrm{DI}: \mathrm{X} 1=\mathrm{X} 2: \mathrm{T} 1=\mathrm{T} 2: \mathrm{D} 1=\mathrm{D} 2: \text { GOTO } 50
\end{aligned}
$$

\section{POKE 216,0: PRINT" INTEGRAL SUM ";:}

PRINT" ";II: PRINT D\$;"CLOSE": PRINT D\$;"PR\#O": END

\section{REM PRINT FORMATTING}

PRINT RIGHTS ("

$"+\operatorname{LEFT\$ }(\operatorname{STR} \$(z), 10), 12) ;: \operatorname{RETURN}$

REM INITIALIZATION

D\$ $=$ CHR\$ (4): INPUT "FILE NAME: ";FI\$

RO $=9.9917 \mathrm{E} 9: \mathrm{K}=23056: \mathrm{II}=0$

*Because the computer program cannot include subscript symbols, the constant denoted by " $R_{o}$ " in the text is represented by "R0" in the program. 
$50020 \mathrm{Al}=.99997: \mathrm{A} 2=3.03962: \mathrm{B} 1=5.03637: \mathrm{B} 2=4.19160: \mathrm{DEF} \quad \mathrm{FN} \mathrm{XE}(\mathrm{X})=$ $(\mathrm{A} 1 * \mathrm{X}+\mathrm{A} 2) /((\mathrm{X}+\mathrm{B} 1) * \mathrm{X}+\mathrm{B} 2):$ REM FUNCTION IS

$1.0-X * \operatorname{EXP}(\mathrm{X}) * \mathrm{E} 1(\mathrm{X})$

50021 REM SEE ABRAMOWITZ \& STEGUN, PAGE 231, EQ'N 5.1.55.

$50030 \mathrm{DEF} F \mathrm{FN}(\mathrm{X})=((\mathrm{C} 1-\mathrm{C} 2) * \mathrm{FNXE}(\mathrm{X})+\mathrm{C} 2 / \mathrm{X}) * \operatorname{EXP}(-\mathrm{X}) / \mathrm{X}$

50040 RETURN

The following variables are used in the program:

$\begin{array}{ll}\text { A } & \text { Cross-sectional area of the fluid passageway } \\ \text { A1, A2, B1, B2 } & \begin{array}{l}\text { Constants used to compute the exponential integral. (See } \\ \text { Abramowitz and Stegun, p. 231.) } \\ \text { C1, C2, C3, C4 }\end{array} \\ \text { Constants computed from input data } \\ \text { Control-D, used by Apple computer to issue disk commands } \\ \text { D1, D2 } & \text { F1uid density at points } 1 \text { and } 2 \\ \text { DI } & \text { Integral of predicted degradation from point } 1 \text { to point } 2 \\ \text { FI\$ } & \text { Input file name } \\ \text { HS } & \text { Informational heading } \\ \text { II } & \text { Total predicted degradation } \\ \text { K } & \text { Constant of the Arrhenius equation } \\ \text { M } & \text { Mass inventory of fluid in the system } \\ \text { R0 } & \text { Constant of the Arrhenius equation } \\ \text { T1, T2 } & \text { Temperature at points } 1 \text { and } 2 \\ \text { TE } & \text { Duration of operation } \\ X & \text { Dummyariable used to define functions } \\ \text { X1, X2 } & \text { Locations of points } 1 \text { and } 2 \text { relative to datum } \\ \mathrm{Z} & \text { Temporary variable }\end{array}$

Computations of predicted degradation are shown below.

\section{DEGREE TEST}

DURATION $=840$

CROSS-SECTIONAL AREA $=0.0731$

FLUID WEIGHT $=11.5$

\begin{tabular}{|c|c|c|c|}
\hline $\mathrm{x}$ & TEMP & DENSITY & INTEGRAL \\
\hline 0 & 943.5 & $9.968 E-04$ & \\
\hline 98 & 1038.6 & $8.561 E-04$ & 0.445023739 \\
\hline 148 & 1078.9 & $8.118 \mathrm{E}-04$ & 0.793262208 \\
\hline 257 & 1135.8 & $7.57 \mathrm{E}-04$ & 4.29078119 \\
\hline 307 & 1138.9 & 7.54300001 & 3.16663015 \\
\hline 518 & 1143.5 & $7.502 E-04$ & 14.246291 \\
\hline 564 & 1141.4 & $7.519 \mathrm{E}-04$ & 3.16964631 \\
\hline 662 & 1141 & $7.524 \mathrm{E}-04$ & 6.6145264 \\
\hline 708 & 1140 & $7.533 E-04$ & 3.06937864 \\
\hline 963 & 1140 & $7.533 \mathrm{E}-04$ & 16.874501 \\
\hline 1095 & 1095.4 & $7.948 \mathrm{E}-04$ & 6.12679581 \\
\hline 1096 & 1085.8 & $8.206 \mathrm{E}-05$ & 0.015779272 \\
\hline 1130 & 1085.8 & $8.206 \mathrm{E}-05$ & 0.08930802 \\
\hline & \multicolumn{2}{|c|}{ INTEGRAL SUM } & 58.9019238 \\
\hline
\end{tabular}

Measured degradation is $76.3 \mathrm{ppm}$. Error in the prediction is $-23 \%$. 
600 DEGREE TEST

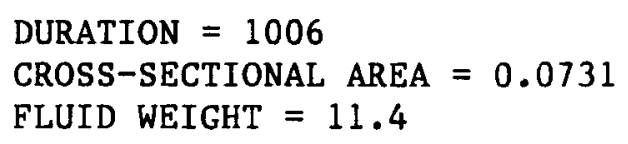

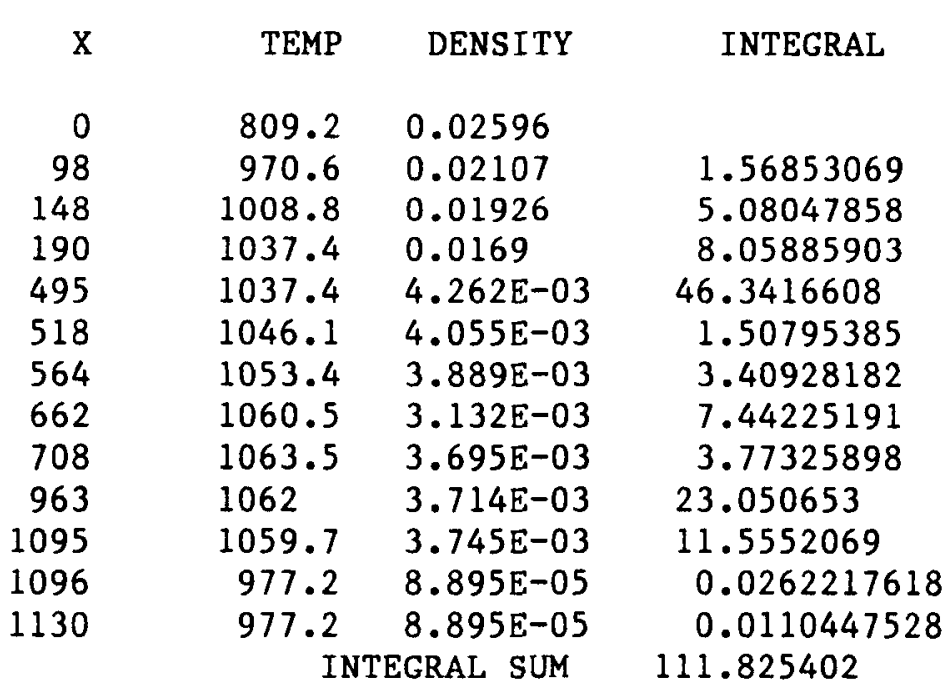

Measured degradation is $105.4 \mathrm{ppm}$. Error in the prediction is $+6 \%$.

\section{DEGREE TEST}

\begin{tabular}{|c|c|c|c|}
\hline \multicolumn{4}{|c|}{$\begin{array}{l}\text { CROSS-SECTIONAL AREA }=0.0731 \\
\text { FLUID WEIGHT }=11\end{array}$} \\
\hline $\mathrm{x}$ & TEMP & DENSITY & INTEGRAL \\
\hline 0 & 845.9 & 0.02503 & \\
\hline 98 & 1029.7 & 0.01773 & 5.45126037 \\
\hline 100 & 1038.6 & 0.01677 & 0.479086155 \\
\hline 220 & 1038.6 & $4.342 E-03$ & 19.3414882 \\
\hline 257 & 1063.5 & $3.749 \mathrm{E}-03$ & 2.98472557 \\
\hline 307 & 1090.3 & $3.418 E-03$ & 6.06538151 \\
\hline 518 & 1119.4 & $3.106 \mathrm{E}-03$ & 40.0612632 \\
\hline 564 & 1119.8 & $3.104 E-03$ & 10.8676496 \\
\hline 662 & 1121.2 & $3.094 \mathrm{E}-03$ & 23.4940566 \\
\hline 708 & 1121.3 & $3.093 \mathrm{E}-03$ & 11.1607982 \\
\hline 963 & 1121 & $3.096 \mathrm{E}-03$ & 61.7761491 \\
\hline 1095 & 1109.7 & $3.178 E-03$ & 29.1640439 \\
\hline 1096 & 1044.2 & $8.571 E-05$ & 0.0701111439 \\
\hline 1130 & 1044.2 & $8.571 \mathrm{E}-05$ & 0.0501214574 \\
\hline \multicolumn{4}{|c|}{ INTEGRAL SUM } \\
\hline
\end{tabular}

Measured degradation is $228.0 \mathrm{ppm}$. Error in the prediction is $-7 \%$. 


\section{DEGREE TEST}

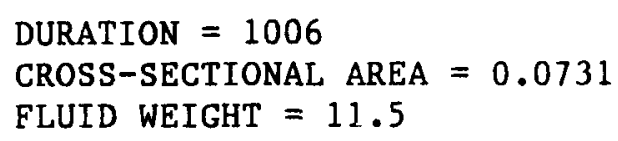

\begin{tabular}{|c|c|c|c|}
\hline $\mathrm{X}$ & TEMP & DENSITY & INTEGRAL \\
\hline 0 & 857.5 & 0.02472 & \\
\hline 98 & 1020.4 & 0.01845 & 4.84511975 \\
\hline 106 & 1039.3 & 0.01668 & 1.7047221 \\
\hline 228 & 1039.3 & $4.392 E-03$ & 19.0560628 \\
\hline 257 & 1058.3 & $3.873 E-03$ & 2.17632502 \\
\hline 307 & 1084.5 & $3.52 E-03$ & 5.35991704 \\
\hline 518 & 1136.1 & $3.008 \mathrm{E}-03$ & 43.1309723 \\
\hline 564 & 1139.8 & $2.981 \mathrm{E}-03$ & 13.9753493 \\
\hline 662 & 1114 & $2.95 E-03$ & 24.3785347 \\
\hline 708 & 1146 & $2.935 \mathrm{E}-03$ & 12.0533928 \\
\hline 963 & 1150 & $2.905 E-03$ & 90.2068855 \\
\hline 1095 & 1137.5 & $2.998 \mathrm{E}-03$ & 43.8539656 \\
\hline 1096 & 1076.4 & $8.281 E-05$ & 0.109463765 \\
\hline 1130 & 1076.4 & $8.281 E-05$ & 0.0896659795 \\
\hline & & GRAL SUM & 260.940377 \\
\hline
\end{tabular}

Measured degradation is $246.0 \mathrm{ppm}$. Error in the prediction is $+6 \%$.

\section{SUNDSTRAND/NASA 750-DEGREE LOOP TEST}

\begin{tabular}{|c|c|c|c|}
\hline \multicolumn{4}{|c|}{$\begin{array}{l}\text { CROSS-SECTIONAL AREA }=0.1452 \\
\text { FLUID WEIGHT }=36\end{array}$} \\
\hline $\mathrm{X}$ & TEMP & DENS ITY & INTEGRAL \\
\hline 0 & 760 & 0.02718 & \\
\hline 34 & 840 & 0.02525 & 0.0332614046 \\
\hline 137 & 990 & 0.02052 & 4.09920671 \\
\hline 272 & 1067 & 0.01405 & 41.8336167 \\
\hline 413 & 1100 & $6.859 \mathrm{E}-03$ & 76.5689867 \\
\hline 565 & 1155 & $3.915 E-03$ & 98.8517053 \\
\hline 721 & 1178 & $3.666 \mathrm{E}-03$ & 143.143812 \\
\hline 820 & 1193 & $3.529 \mathrm{E}-03$ & 118.1031 \\
\hline 884 & 1203 & $3.438 \mathrm{E}-03$ & 90.4842306 \\
\hline 927 & 1210 & $3.374 E-03$ & 68.050629 \\
\hline & & EGRAL SUM & 641.168548 \\
\hline
\end{tabular}

Measured degradation is $1212.9 \mathrm{ppm}$. Error in the prediction is $-47 \%$. 